\title{
GLOBAL ANTISEMITISM: \\ A CRISIS OF MODERNITY
}

\author{
Volume III \\ Global Antisemitism: \\ Past and Present
}

Charles Asher Small

Editor 


\author{
Honorary President \\ Professor Elie Wiesel \\ Director \\ Charles Asher Small \\ Co-Chairs of the International Academic Board of Advisors \\ Professor Irwin Cotler \\ Professor Alan Dershowitz \\ ISGAP Europe - Coordinator \\ Robert Hassan \\ ISGAP Asia - Chair \\ Jesse Friedlander \\ Publications Consultant \\ Alan Stephens \\ Administrative Coordinator \\ Jenny Pigott \\ ISGAP \\ 165 East 56th Street, 2nd Floor \\ New York, New York 10022 \\ Phone: 212-230-1840 \\ Fax: 212-230-1842 \\ www.isgap.org
}

The opinions expressed in this work are those of the author(s) and do not necessarily reflect the views of the Institute for the Study of Global Antisemitism and Policy, its officers or the members of its Boards.

Cover by Romijn Design

Layout by AETS

Printing and binding by Graphos Print 
For Professor William Prusoff 


\section{About the Editor}

Dr. Charles Asher Small is the Director of the Institute for the Study of Global Antisemitism and Policy (ISGAP). He is also the Koret Distinguished Scholar at the Hoover Institution, Stanford University. Charles received his Bachelor of Arts in Political Science, McGill University, Montreal; a M.Sc. in Urban Development Planning in Economics, Development Planning Unit (DPU), University College London; and a Doctorate of Philosophy (D.Phil), St. Antony's College, Oxford University.

Charles completed post-doctorate research at the Groupement de recherche ethnicité et société, Université de Montréal. He was the VATAT Research Fellow (Ministry of Higher Education) at Ben Gurion University, Beersheva, and taught in departments of sociology and geography at Goldsmiths' College, University of London; Tel Aviv University; and the Institute of Urban Studies, Hebrew University, Jerusalem.

Charles was the founding Director of the Yale Initiative for the Interdisciplinary Study of Antisemitism (YIISA), the first interdisciplinary research center on antisemitism at a North American university. At Yale he taught in the Political Science Department and the Program on Ethics, Politics and Economics, and ran a post-doctorate and graduate studies fellowship program at YIISA. He was also an Associate Professor and the Director of Urban Studies at Southern Connecticut State University (SCSU). He has lectured internationally and worked as a consultant and policy advisor in North America, Europe, Southern Africa, and the Middle East. Charles specializes in social and cultural theory, globalization and national identity, socio-cultural policy, and racism(s) including antisemitism. 


\section{Acknowledgements}

This series of volumes is the result of many people contributing at various levels.

I would like to thank the members of the ISGAP Board of Trustees who funded YIISA's activities and also underwrote the conference on which this series is based, "Global Antisemitism: A Crisis of Modernity," which was held at Yale University in August 2010. I am most grateful to Lawrence Benenson, Irwin Hochberg, Mort Lowenthal, Roger Hertog, Mark Rosenblatt, David Messer, Lloyd Fischler, Zahava Gordon, Alvin Prusoff, Robert Satloff, Larry Schiffres, Ron Stackler, Jonathan Torop, Jennifer Roskies, Jessie Friedlander, and Mitchell Wesley. I am also thankful to Kathrin Haurand for her support. I am also appreciative of the support of the members of ISGAP's Academic Advisory Committee, including its remarkable Co-Chairs Professors Irwin Cotler and Alan Dershowitz, and Honorary President Professor Elie Wiesel. I am also grateful to Ben Farahi, Rabbi Bruce Alpert, Allon Canaan, Michelle Whiteman, and Albert Bildner. The conference was partly sponsored by the Isaac and Jessie Kaplan Centre for Jewish Studies and Research, University of Cape Town. For this, I am especially grateful to Centre's Director, Milton Shain.

I would also like to thank the Koret Foundation for making me their Distinguished Scholar at the Hoover Institution, Stanford University. I am thankful to Professor David Brady, Abe Sofaer, Marc Abramowitz, and Peter Berkowitz and to Tad Taube, Tina Frank, and Danielle Forman. At the Hoover Institution, I found a space where academic freedom, debate, and discussion is not only permitted but truly encouraged. This is crucial during these times, especially in relation to the study of contemporary antisemitism. I am also thankful to Raphael Fischler, Doron Ben-Atar, Shalem Coulibaly, Jeffrey Herf, and Olufemi Vaughan.

I am especially grateful to all the scholars who attended the conference. Most of them did so at their own expense and traveled considerable distances to be there. The conference, on which this series is based, was the largest academic gathering ever on the study of antisemitism. More than one hundred speakers from approximately twenty academic fields and more then twenty countries attended the event. It was truly a remarkable gathering at an important historical moment. Due to the high level of scholarship, the conference produced many key insights and has given rise to many important research projects.

Finally, I would like to thank Daniel Stephens for copy-editing and reviewing the contributions for this project. I am most grateful for his professionalism, patience, and assistance, often beyond the call of duty. Without his efforts these volumes would not have been possible. I am thankful to Alan Stephens for his much-valued advice and for making this publication possible in the first place. I am also most grateful to Lauren Clark and would like to thank Ulrike Becker, Idit Shalev, Tatenda Mujeni, Della Fok, Aleksandra Gliszczyńska-Grabias, Carlton Long, Zachary Izenberg, Dovid Katz, and Evan Weiser for their assistance during the conference. 
This series is dedicated to the memory of Professor William (Bill) Prusoff. Bill was the founding member of ISGAP and funded much of our activities from 2004 until his passing in 2011. Without his support, ISGAP would not have been able to establish YIISA at Yale University. In many ways, Bill's reputation as a scholar and an exceptional mensch paved the way for our work. Rarely in one's life does one have the privilege to meet someone of Bill's stature. He was a medical genius who created the first generation of anti-viral and anti-HIV medications that helped to save or prolong the lives of millions. Yet despite his incredible accomplishments, Bill was the most humble, kind, and amiable person I have ever met. Bill never forgot where he came from. He often recounted how his family had to flee Brooklyn for Miami in the 1930s after "Brown Shirts" thugs attacked the family store or how he was refused entry to Yale's Medical School because of the Jewish quota that was in place at the time. Nevertheless, he eventually managed to become a tenured professor at Yale as well a true giant in his field. In the Jewish tradition there is a belief that, at any given time, there are 36 hidden righteous people (Tzadikim Nistarim) in the world whose role in life is to justify the purpose of humankind in the eyes of G-d. For those of us who knew Bill, this idea did not seem beyond the realm of possibilities. He is missed.

Charles Asher Small

December 2013 


\section{Table of Contents}

Introduction 1

Charles Asher Small

Antisemitism and Anti-Zionism in the "New" South Africa:

Observations and Reflections 21 Milton Shain

The Politics of Paranoia: How - and Why - the European Radical Right Mobilizes Antisemitism, Xenophobia, and Counter-Cosmopolitanism 29 Lars Rensmann

Penalizing Holocaust Denial: A View from Europe 43 Aleksandra Gliszczyńska-Grabias

The Judeo-Masonic Enemy in Francoist Propaganda (1936-1945) 63 Javier Domínguez Arribas

"Artisans ... for Antichrist": Jews, Radical Catholic Traditionalists, and the Extreme Right..... 71

Mark Weitzman

Post-war Antisemitism: Germany's Foreign Policy Toward Egypt 89 Ulricke Becker

Great Expectations: Antisemitism and the Politics of Free-Speech Jurisprudence.

Stephen M. Feldman

A Brief History of Iberian Antisemitism 103 Lina Gorenstein

Antisemitism in Contemporary Poland Marek Kucia

Anti-Jewish "Propaganda" in Brazil under Dutch Occupation Daniela Levy

Antisemitism According to Victor Klemperer 133 Miriam Oelsner

Antisemitic Anti-Zionism Within the German Left-Die Linke

Sebastian Voigt

Two Thousand Years of Antisemitism: From the Canonical Laws

to the Present Day 151 Anita Waingort Novinsky

Table of Contents of Volumes I-V 



\section{Introduction}

\section{Charles Asher Small}

In August 2010, the largest-ever academic conference on the study of antisemitism took place at Yale University. The conference, entitled "Global Antisemitism: A Crisis of Modernity," was hosted and organized by the Yale Initiative for the Interdisciplinary Study of Antisemitism (YIISA) and the International Association for the Study of Antisemitism (IASA). The conference featured over 100 speakers from more than 20 countries from around the world. They included recent graduates at the beginning of their academic careers, experienced academics, and leading senior scholars who have dedicated their intellectual pursuits to the study of antisemitism, as well as legal experts, practitioners and others. More than 600 people attended the conference, including undergraduate and graduate students, scholars from many universities, including Yale University, practitioners and members of non-governmental organizations, civil servants and diplomats interested in the policy implications of the subject matter, and members of the general public. This volume presents a selection of the many important and challenging papers presented at the conference. It is one of five volumes reflecting the interdisciplinary nature of the conference as well as the diverse nature of the subject of antisemitism in general.

The Institute for the Study of Global Antisemitism and Policy (ISGAP) was established in 2004, with a network of scholars from around the world and the support of a group of dedicated philanthropists led by the humanitarian and professor of pharmacology William (Bill) Prusoff, in response to a clear and ominous increase in global antisemitism. ${ }^{1}$ In 2006, ISGAP approached Yale University with a view to establishing an academic research center within the university. After determining that the center would meet all the necessary administrative, financial, and academic requirements, Yale University inaugurated the Yale Initiative for the Interdisciplinary Study of Antisemitism (YIISA) in 2006. It was the first academic research center focusing on the interdisciplinary study of antisemitism to be based at a North American university. ${ }^{2}$ ISGAP's Board of Trustees supported and funded all of YIISA's activities, co-sponsoring

1 In his opening remarks at the United Nations conference "Confronting anti-Semitism: Education and Tolerance and Understanding," June 21, 2004, New York, Professor Elie Wiesel examined the rising levels and threat of antisemitism. The rise in contemporary global antisemitism is examined and substantiated in several chapters in this volume.

2 The fact that the first interdisciplinary and fully fledged research center on antisemitism at a North American university was only established in 2006 ought itself to be a the focus of a research project, especially given the role antisemitism has played in Western civilization. 
its seminar series and various other events and paying the salaries of its 14 employees. It also underwrote the August 2010 conference on which the above-mentioned five volumes are based. ${ }^{3}$

From 2006 to 2011, YIISA offered a successful graduate and post-doctorate fellowship program. Each year, it welcomed a group of scholars from leading universities in the United States and around the world, including several senior visiting professors. YIISA had a robust programming agenda. It organized over 120 seminars, special events, a series of films, four international conferences, symposiums and other gatherings at Yale University in New Haven, as well in New York, Washington, and Berlin. Its scholars carried out research projects and published important material on the interdisciplinary study of antisemitism. ISGAP and YIISA met the need to examine the changing contemporary state of and processes pertaining to global antisemitism. The fact that over 100 speakers participated in the aforementioned 2010 conference, and that all but ten of them attended at their own expense, is testimony to the extensive interest in the study of contemporary antisemitism.

The conference, "Global Antisemitism: A Crisis of Modernity," offered an environment in which scholars from a wide array of disciplines, intellectual backgrounds, and perspectives would be able to present their research and engage in interdisciplinary debate. The call for papers was inclusive and encouraged scholars from around the world to present their work. Without such a free exchange of ideas, any notion of academic freedom is tantamount to rhetoric. The subject of antisemitism is complex and controversial, as many students and scholars of this subject know. It was therefore important to YIISA to provide a forum in which this important issue could be freely discussed and explored. ${ }^{4}$

3 ISGAP continues as a research center with its head office in New York. It develops academic programming at top universities, including McGill, Fordham (Lincoln Center Campus), Harvard Law School, and the Stanford's Hoover Institution.

${ }^{4}$ It is not uncommon for scholars of antisemitism, especially those engaged in the study of its contemporary manifestations, to be labeled as right-wing, neo-conservative, or Islamophobic. Likewise, despite their obvious and sometimes extraordinary credentials, their scholarship is often unfairly categorized as "advocacy." Such accusations, which are often made by those who engage in advocacy themselves, actually constitute a form of antisemitism. Others simply embrace the "gatekeeper" role within the academy, which Cohen describes as an attempt to maintain the status quo on behalf of institutional interests. See Robin Cohen, The New Helots: Migrants in the International Division of Labour (Gower Publishing, Aldershot 1987) and E. Bonacich, "A Theory of Middleman Minorities," American Sociological Review Vol. 38 (1973) pp. 583-594. This is reminiscent of the McCarthy era interference with academic freedom. At that time, a notable scholar, Nathan Glazer, took it upon himself to report on members the Jewish community to the "Committee" in order to silence political views that were deemed unacceptable at the time (Cedric Robinson, Black Marxism: The Making of the Black Radical Tradition (Zed Books, London 1983)). The academic activities of YIISA, in particular its work on state-sponsored antisemitism, Iran, and the Muslim Brotherhood, was denounced as "advocacy" by those with an interest in promoting the US administration's general policy of "engagement" with Islamic states. Analogous views also found support within the Yale Corporation and administration, as well as among several tenured faculty, resulting in a de facto limitation of academic freedom. These perspectives were conveyed directly to my colleagues and me by leading members of the Yale administration and faculty members. It thus appears that the scholarly analysis of antisemitism in contemporary Middle Eastern societies infringed upon various political and economic priorities. Moreover, the possible investment of Gulf funds in Yale University, and other universities around the world, or fear of the discontinuation of such funding, is a 
In June 2004, the United Nations, an institution that emerged from the ashes of World War II and the Holocaust, held its first official conference on antisemitism. This gathering served as a formal acknowledgement of the re-emergence of antisemitism as a contemporary matter of concern in a changing and globalizing world. It was hosted by UN Secretary General Kofi Annan and Nobel peace laureate Professor Elie Wiesel at the UN headquarters in New York. ${ }^{5}$ Wiesel, the keynote speaker in a packed General Assembly Hall, noted that antisemitism is the oldest collective form of hatred in recorded history and that it had even managed to penetrate the United Nations itself. He questioned whether the world body, despite its role as a moral and political global leader, had forgotten the destructive and deadly impact of antisemitism. Some in attendance, Wiesel pointed out, actually endured its consequences: "We were there. We saw our parents, we saw our friends die because of antisemitism." In my view, the 2004 UN conference on antisemitism marked a turning point in the response of academia to the subject of antisemitism. This renewed interest was a contributing factor in the establishment of ISGAP several months later.

The YIISA conference addressed two inter-related and important areas of research that both encompass various disciplines, namely (1) global antisemitism and (2) the crisis of modernity currently affecting the core elements of Western society and civilization. Is it possible that the emergence of the current wave of global antisemitism both reflects and forms part of a wider attack on the core elements of modernity, notions of Enlightenment, and Western civilization more generally by reactionary social forces empowered by the crisis of capitalism? Against this background, the participants in the conference addressed conceptual and empirical questions from a wide array of perspectives and disciplines. The diversity in approach and opinion was itself a sign of academic health.

Antisemitism is a complex and, at times, perplexing form of hatred. Some observers refer to it as the "longest hatred." It spans centuries of history, infecting different societies, religious, philosophical and political movements, and even civilizations. In the aftermath of the Holocaust, some have even argued that antisemitism illustrates the limitations of the Enlightenment and modernity itself. Manifestations of antisemitism occur in numerous ideologically-based narratives and in constructed identities of belonging and Otherness such as race and ethnicity, as well as nationalist and antinationalist movements. In the contemporary context of globalized relations, it appears that antisemitism has taken on new complex and changing forms that need to be decoded, mapped, and exposed. The academic study of antisemitism, like prejudice more generally, has a long and impressive intellectual and research history. It remains a topic

question meriting unfettered research rather than a statement of fact. The question whether this socalled "advocacy," which allegedly affected research on antisemitism, ought to be replaced by kosher "non-advocacy" research that does not disturb governmental or foreign donor sensibilities must now be on the table as an open question for research. Additionally, against this background, the possibility that the term "advocacy" itself has become a euphemism for "research relevant to current affairs and therefore likely to offend some powerful parties" must be subjected to critical scholarly scrutiny.

5 Professor Elie Wiesel is the Honorary President of ISGAP. 
of ongoing political importance and scholarly engagement. However, especially at this important historical juncture, unlike prejudice and discrimination directed at other social groups, antisemitism-in particular its contemporary forms and processes-is almost always studied outside an organized academic framework.

The purpose of YIISA's 2010 conference was therefore to explore this subject matter in a comprehensive manner and from an array of approaches and perspectives, as well as in its global, national, and regional contexts. The development of an interdisciplinary approach and consciousness, while encouraging analytical studies examining a prejudice that remains widespread and but also appears to be experiencing a resurgence, was a key objective of the conference and YIISA's general mission. The conference aimed to create a vibrant space in which high-caliber scholarship and open and free debate would develop, be nurtured, and have an impact. ${ }^{6}$

The process of globalization has led to an increase in adversarial identity politics. In this environment, Israel, as a central manifestation of contemporary Jewish identity, and Jews more generally have become the focus of scapegoating and hateful rhetoric. At a more structural and socio-historical level, the old ideologies and tendencies of antisemitism have re-emerged and are being fused with anti-Zionism or what in many cases might be more appropriately described as Israel-bashing. ${ }^{7}$ The old theological and racist forms of European antisemitism are being amalgamated with anti-Jewish and anti-Israel pronouncements emanating in particular from the Muslim world, which is located mainly, but not exclusively, in and around the Middle East. Contemporary globalization and the related socio-economic, cultural, and political processes are being fused with these histori-

6 The establishment of a research center similar to YIISA is urgently required within the academy. The approach of such an entity should be analogous to the one adopted by the Centre for Contemporary Cultural Studies (CCCS) at the University of Birmingham (UK) and the Centre for Research in Ethnic Relations (CRER) at the University of Warwick (UK), yet with a specific critical approach to antisemitism. Both centers adopted an interdisciplinary approach with an emphasis on critical conceptual analysis based on solid empirical research. Currently, there are several small entities that study antisemitism, but they are all led by European historians with little or no background in the contemporary, regional, or interdisciplinary context. In fact, several of these scholars actually blame Israel for contemporary manifestations of antisemitism and underestimate the relevance of Islamism. This perspective is often based on "politically correct" views rather than rational scholarship. There is a need for vibrant analysis, study, discussion, and debate. A new entity for the study of antisemitism ought to combine an understanding of Western antisemitism and notions of "Otherness" with a willingness to tackle the contemporary changes sweeping the Middle East and knowledge of the region and its culture, including Islam and Islamism. The study of terrorism as it relates to contemporary antisemitism is also very much required. All these issues should obviously be examined in the context of processes associated with globalization, as opposed to the more frequently-used and descriptive concept of global antisemitism. Descriptive work without a critical, comprehensive, and conceptual interdisciplinary analytical framework will not be effective in assessing the contemporary condition, nor in creating appropriate policy responses. Policy development is a recognized and respected field of study within academia. This must be stated, since many who analyze antisemitism are "gatekeepers" who dismiss this vital scholarship as advocacy. This is not only problematic but also hinders the finding of solutions to key issues, indirectly undermining the safety of many.

7 For an analysis linking classical forms of antisemitism with contemporary Israel-bashing, see Edward H. Kaplan and Charles A. Small, "Anti-Israel Sentiment Predicts Anti-Semitism in Europe," Journal of Conflict Resolution, Vol. 50, No. 4, August 2006. 
cal tendencies, creating the conditions that pose a threat to Jewish people and Jewish communities in the Diaspora. In addition, new structural realities within the realm of the international relations and the emergence of anti-Israel propensities appear to pose a threat to Israel and the Jewish people in a manner not seen since the end of World War II. Once again, in this age of globalization, the Jewish people seem to be caught between the "aristocracy" or "wealthy establishment" (core) and the marginalized or disenfranchised masses (periphery), as they have been throughout most of history. ${ }^{8}$

With the advent of the "socialism of fools," a term describing the replacement of the search for real social and political equity with antisemitism that is frequently attributed to August Bebel, Jews continued to be targeted. ${ }^{9}$ In much the same way, the current marginalization of the Jewish people in the Arab world-or, more accurately, the marginalization of the image of the Jew, since most of them were pressured to leave or expelled from Arab countries between 1948 and the early 1970s after a strong continual presence of thousands of years-is staggering. As the social movements in the Middle East have turned to their own version of the "socialism of fools" (i.e., the antisemitism of radical political Islamism), they have incorporated lethal forms of European genocidal antisemitism as their fuel. ${ }^{10}$ However, many scholars, policy-makers, and journalists of record still refuse to acknowledge this fact and to critically examine the ideology and mission of this social movement.

Anti-Judaism is one of the most complex and at times perplexing forms of hatred. As evident from the range of papers presented at the conference and in these volumes, antisemitism has many facets that touch upon many subjects and scholarly disciplines. The term "anti-Semitism," which was coined in the 1870 s by Wilhelm Marr, ${ }^{11}$ is also controversial and at times confusing. Yet despite its etymological limitations and contradictions, it remains valid and useful. The term refers specifically to prejudice and discrimination against the Jewish people. Some incorrectly or for reasons of political expediency use the term to refer to prejudice against all so-called "Semitic" peoples, claiming that Arab peoples cannot be antisemites, as they are Semites themselves. This is

8 See the Arab Human Development Report (United Nations Development Programme 2005). This report and other subsequent reports examine the impact of globalization on aspects of socioeconomic marginalization stability in the Arab world.

9 Steve Cohen, That's Funny You Don't Look Anti-Semitic. An Anti-Racist Analysis of Left AntiSemitism (Leeds 1984). The well-known saying "Anti-Semitism is the socialism of fools" ("Der Antisemitismus ist der Sozialismus der dummen Kerle") is frequently attributed to Bebel, but probably originated with the Austrian democrat Ferdinand Kronawetter; it was in general use among German Social Democrats by the 1890s (Richard J. Evans, The Coming of the Third Reich (Penguin Group 2005)). For a discussion of antisemitism, including the notion of the socialism of fools, see David Hirsh, Anti-Zionism and Antisemitism: Cosmopolitan Reflections, The Yale Initiative for the Interdisciplinary Study of Antisemitism Working Paper Series, Editor Charles Asher Small, Vol. 1, No. 1 (2007).

10 In Islamism and Islam (Yale University Press 2011), Bassam Tibi makes the important distinction between antisemitism that was European in origin and genocidal, on the one hand, and the kind of anti-Judaism that was discriminatory in nature, which was historically prevalent in the Middle East and Islamic context, on the other. For various reasons why the antisemitism taking hold in Muslim societies in the contemporary condition has much in common with European genocidal antisemitism, see the contributions on this subject in the present volume.

11 Shlomo Avineri, Karl Marx on Colonialism and Modernization (New York 1968). 
fine in terms of etymological musing but not in terms of the history of language and thought, where terms acquire specific meanings over time that diverge from their etymological origins. In fact, antisemitism refers to a specific form a hatred that is mainly European in origin and focuses upon the Jewish people. Some scholars prefer to use the term antisemitism, without a hyphen and uncapitalized, since it refers to a form of hatred or a phenomenon rather than to a specific race or biologically determined group. Emil Fackenheim, for example, used the unhyphenated form for this reason. ${ }^{12}$ These volumes and all of ISGAP's other work also follows this approach.

Some scholars who have examined the complexities of antisemitism claim that it takes several forms, including social, economic, political, cultural, and religious antisemitism. René König, for example, contends that these different forms of antisemitism demonstrate that the origins of antisemitism are rooted in different historical periods and places. ${ }^{13}$

When religion, in particular Christianity, represented the dominant way to perceive reality, the Jews were regarded as followers of the wrong religion. It was also believed that their refusal to accept the Christian messiah disqualified them from any form of redemption and even that Jewish stubbornness hindered world redemption. Finally, it is hardly necessary to recall that the Jews were accused of deicide. When the dominant manner in which Europeans perceived reality was based on the nation state and biological notions of race and ethnicity, the Jews were constructed as belonging to another, inferior race. According to the Nazis and others who subscribed to racist beliefs, for example, they were perceived as polluting the Aryan race and needed to be removed completely in order to save the purity of the "race" and "nation."

At present, some argue for religious reasons that the self-determination of the Jewsthe non-Muslim "Other" - on so-called Islamic land is a sin and should not be tolerated. Others, in the West, see Jewish stubbornness as the cause of radical Islam, Jihadism, and the instability in the region. When it comes Israel's policies and existence, they believe that if only the Jews would change the problems in the region and in international relations as a whole could be resolved. ${ }^{14}$ If taken to its logical conclusion, this perspective could lead to great destruction, like other historical manifestations of antisemitism, since its aims is the eradication of Israel or any semblance of Jewish self-determination in the region. ${ }^{15}$ Despite the complete rejection of the Jewish narrative by the Iranian regime, Hamas, Hezbollah, and other Salafists and Islamists, many observers focus on the "Other" and are content to blame the "victim" of this ideology without properly examining it. In fact, attempts to critically examine these reactionary views are often deemed politically unacceptable. This contemporary form of antisemitism has many layers. New forms are mixed with older ones, such as conspiracy theories about Jewish power and culture, apocalyptic theories concerning the Jews. For example, the Protocols

12 Emil Fackenheim, "Post-Holocaust Anti-Jewishness, Jewish Identity and the Centrality of Israel," in Moshe Davis, ed., World Jewry and the State of Israel (Arno Press 1977).

13 René König, Materialien zur Krimalsoziologie (VS Verlag 2004).

14 It is important to note that, in the contemporary US context, some political realists certainly fall into the category of those who blame Israel for all the problems in the region and beyond.

15 Cf. Norbert Elias, The Civilizing Process (2000) (originally published as Über den Prozess der Zivilisation in two separate volumes in 1939 by Haus zum Falken, Basel). Refusing to recognize the Other and insisting on changing them fundamentally will inevitably lead to violence and even destruction. 
of the Elders of Zion, which played a key role in creating the conditions for the Holocaust, as well European antisemitism more generally, has now become part of the political and cultural mainstream in several Arab and Muslim societies. ${ }^{16}$

The above-mentioned complexities make it difficult to define the different forms that antisemitism takes. This in turn makes it problematic to address and analyze the subject matter. It is no wonder, then, that contemporary forms of antisemitism have always been difficult if not impossible to acknowledge, study, measure, and oppose. One hopes that it will not only be future historians who come to understand and address today's lethal forms of antisemitism, too late to affect policy, perceptions, and predispositions.

The context of contemporary global antisemitism, on which the conference focused, covers international relations, which are increasingly in a state of flux and turmoil, as well as notions of tolerance, democratic principles and ideals, human rights, and robust citizenship. These values appear to be receding within many institutions and societies, while the international community seems to be less strident in trying to defend them. It would appear that the Jew, or perhaps more importantly the image of the Jew or the "imaginary Jew" as described by Alain Finkielkraut, ${ }^{17}$ is at the middle of this global moment. Both historically and today, antisemitism is a social disease that begins with the Jews but does not end with them, making the Jewish people the proverbial canary in the coalmine. This deadly strain of hatred often turns against other groups, such as women, homosexuals, moderate Muslims, and other sectors of the population who are perceived as not being ideologically pure, as well as against key democratic notions such as robust citizenship, equality before the law, and religious pluralism. Antisemitism is consequently a universal human rights issue that should be of importance to all.

In view of its character as the "longest hatred," with a destructive power that is both well known and well documented, the historical lessons of antisemitism ought to reach beyond the Jewish people and concern scholars from a wide range of disciplines, both academic and policy-oriented. In fact, antisemitism should be perceived as a key aspect in the development of Western civilization, yet it is often perceived as a Jewish or parochial issue. ${ }^{18}$ This perception forms an impediment to the study of antisemitism in current academic culture, which favors the universal over the particular. In fact, the study of antisemitism is often regarded as unworthy of consideration or even as an enemy of the progressive universalistic worldview that is currently in vogue.

Certain members of the academic community, especially those who claim to espouse progressive and/or postmodernist views, often perceive the study of antisemitism as an

16 See Bassam Tibi, Islamism and Islam (Yale University Press 2011); Neil Kressel, The Sons of Pigs and Apes: Muslim Antisemitism and the Conspiracy of Silence (Westview Press 2012). Bassam Tibi was a Visiting Professor and Neil Kressel a Visiting Fellow at YIISA. As Israel becomes the focus of contemporary discourse and manifestations of antisemitism, even in the United States, the notions of "dual loyalty" and the "Jewish lobby," which were previously articulated mostly by extremists, have gained credibility with the publication of a controversial book on the subject by Walt and Mearsheimer in 2007 (The Israel Lobby and US Foreign Policy) and the approach of some "realists" who have gained influence in the past several years in the media and policy circles.

17 Alain Finkielkraut, The Imaginary Jew (University of Nebraska Press 1994).

18 The members of ISGAP specifically established YIISA, the first-ever research center focusing on the interdisciplinary study of antisemitism at a North American university, to create a space to engage in this subject matter freely. 
attempt to undermine criticism of the State of Israel and accuse those engaged in this study of being political advocates rather than pursuers of real scholarship. ${ }^{19}$ In fact, in this postmodern age, this is a fairly common view in academic and intellectual circles. ${ }^{20}$ It is therefore important to embark on a systemic critique of the intellectual and political impact of this philosophical movement not only with regard to the safety and security of the Jewish people and their right to self-determination but also with regard to the integrity of the Enlightenment project and perceptions of modernity.

The contemporary canon includes a critique of the traditional "Western" cannon, for example by Michel Foucault and Edward Said, that has also helped to demonize Jewish cultural and historical narratives in relation to Israel and beyond. This perspective is now an integral component of many "good" university curriculums throughout the West. ${ }^{21}$ Foucault welcomed the Iranian Revolution of 1979 as a triumph of spiritual values over the profanity of Western capitalist materialism. He perceived this Islamist revolution as a critique of Western culture and a protest against the political rationality of modernity. ${ }^{22}$ This sympathetic view of the Islamist revolution has been largely ignored, but it undoubtedly influenced the subsequent philosophical discourse and scholarship. Said, who was in Paris in 1979, fondly recalls spending time with Foucault and notes that they both hoped that the Iranian Revolution would develop into what the French Revolution was to Kant two hundred years earlier. Despite its violence, they hoped that the revolution would be a crucial step toward progress and emancipation for the people of Iran and the oppressed peoples of other nations. ${ }^{23}$ Their critique of modernity and Western colonial power, combined with the lack of an ethical alternative, prevented these early postmodernists from criticizing the excesses of the Iranian revolution and its failure to recognize the 'Other' as an equal and respected member of society. The works of Foucault and Said have thus helped to lay the foundations for the failure of many contemporary intellectuals to condemn the rise of Islamism as a social movement, ${ }^{24}$ especially in relation to its lack of acceptance of basic notions of "Otherness" within Islamic society, a cornerstone of democratic principles, and its vitriolic prejudice against the Jewish people and Israel. This intellectual development should also be considered in the context of global politics and the prevailing environment in many academic institutions, where the need for funding unfortunately appears to be having a growing impact on the curriculum.

19 See Judith Butler, “No, it's not anti-semitic," London Review of Books, August 21, 2003.

20 See Robert Wistrich, From Ambivalence to Betrayal: The Left, the Jews, and Israel (University of Nebraska Press 2012).

21 Charles Asher Small, "The Gaze of the Colonial and Post-Colonial: Judeophobia, Empire and Islamism," Conference: Orientalism Revisited: Art and the Politics of Representation, Paul Goodwin, Curator, Tate Britain, London, June 2008.

22 See Janet Afary and Kevin Anderson, Foucault and the Iranian Revolution: Gender and the Seduction of Islamism (University of Chicago Press 2005). Afary and Anderson examine Foucault's 1978 visit to Iran where he met with leaders of the Iranian-Islamist revolution, including Ayatollah Khomeneini. The authors document how this period influenced the philosopher's understanding of issues such as the Enlightenment, homosexuality, and his quest for the notion of political spirituality. As the book demonstrates, this topic, which has been largely overlooked, is worthy of consideration.

23 Ramin Jahanbegloo, Iran: Between Tradition and Modernity (Lexington Books 2004).

24 For an analysis of the notion of social movements, which are transformational, and protest movements, which are reformist, see Manuel Castells, City, Class, and Power (MacMillan, London 1978). 
Furthermore, Said's attempt to undermine the legitimacy of Jewish self-determination in Israel and the Jewish historical narrative in the Diaspora needs to be critically examined with regard to its role in the re-emergence of antisemitism among intellectuals and ithin the academy. Such a critique of the critique is especially urgent at this time, as there seems to be little possibility to address antisemitism forcefully within the academy or to express outrage and concern regarding the recent successes of Islamism despite its reactionary agenda and worldview. ${ }^{25}$ Instead, these ideological and philosophical foundations enable leading and respected scholars such as Judith Butler to argue that Hamas and Hezbollah ought to be viewed as part as the progressive global left. It also encourages some observers, including scholars of antisemitism, to blame Israel for antisemitism throughout the world. ${ }^{26}$

Even in the aftermath of the Holocaust, and despite the academy's preoccupation with colonialism, racism, sexism, socio-economic, political, and cultural inequality, domination, and critical understandings of "Otherness," antisemitism, especially its contemporary manifestations, does not exist as an area of study in the mainstream academic curriculum. ${ }^{27}$ Unlike other forms of discrimination, antisemitism is not an issue of significant concern. These developments have had the effect of placing attempts to defend the Jews - and their legitimate connection to Israel and Jerusalem - outside the realms of what is acceptable and proper. This is most troubling, given that the legacy of antisemitism in the academy and in Western civilization more generally has yet to be understood and addressed in the same way as other forms of discrimination and hatred. The contemporary perception in some quarters of the Zionist movement as an unfash-

25 Daniel Sibony, Freud, Edward Said and Israel (forthcoming).

26 Id. It is fascinating to note that Jewish scholars who blame Israel for various crimes and even antisemitism itself often enjoy much attention and popularity, more so than scholars doing the serious analysis and research. In fact, this is a common phenomenon with regard to the politics of hatred more generally and historically.

${ }^{27}$ It is worth recalling that during the rise of Nazism the German academy as an institution voluntarily cleansed itself of Jews. See Saul Friedlander, The Years of Persecution: Nazi Germany and the Jews 1933-1939 (Phoenix, London 2007). While I do not wish to compare the German academy of the Nazi era to the present academy, the role of the academy in studying, combating, or promoting contemporary antisemitism ought to be critically examined, regardless of the period. At present, the university campus atmosphere is once again becoming increasingly hostile in terms of the pressures facing Jewish students. In fact, US universities have a history of questionable relations with dubious interests, including the Nazi regime and Islamist interests. See Stephen Norwood, The Third Reich in the Ivory Tower: Complicity and Conflict on American Campuses (Cambridge University Press 2009) and Mitchell Bard, The Arab Lobby: The Invisible Alliance That Undermines America's Interests in the Middle East (Harper Collins 2010). In fact, in late 2009 and early 2010, YIISA was criticized by the Yale Corporation, the Provost, and faculty members for being critical of the Iranian revolutionary regime. The regime had just placed Yale University on a list of institutions considered hostile to the regime and called for Iranians not to have contact with them. See, for example, "Iran Intelligence Ministry Blacklists Yale and Dozens of Other Western Institutions," Los Angeles Times, January 4, 2010. The Provost and several faculty members told me directly that members of the Yale Corporation were angered, as they saw YIISA's work as interfering with the free flow of academic exchanges with Iran and Iranian scholars. During this time, Yale Corporation member Fareed Zakarria (before he resigned over a plagiarism scandal) often supported the policy of "engagement" in his writings, while several YIISA scholars were critical. See $<$ http://www.youtube.com/ watch? $=$ gByfHdLCdhA>. 
ionable, intellectually defunct, and morally bankrupt remnant of Western colonial racist culture-a perception that pays no attention to the competing narrative of Jewish national aspirations or the Jewish people's millennia-spanning history in the region-is therefore a recipe for disaster. At the very least, it creates an uncritical blind spot for the role that antisemitism plays in the contemporary Middle East. To engage in the study of antisemitism is somehow perceived as supportive of the Zionist narrative, while the real threat that antisemitism poses is not understood and no polices are developed to address it, let alone to help thwart it. ${ }^{28}$

In this environment, it is more acceptable to study the role of the Church or the role of fascism in antisemitism rather than its contemporary manifestations. ${ }^{29} \mathrm{In}$ fact, if one looks at the history of antisemitism, it was never acceptable to study or examine contemporary forms of antisemitism at the time in which they occurred. The true challenge of effective and insightful scholarship is to understand the real threat that antisemitism poses to people and society today and to develop policies to protect ourselves against this threat. However, it is not uncommon to find scholars and institutions that are opposed to the study of contemporary antisemitism yet still blame Israel for its renewed prevalence without research to back up these claims. This response is not based on sound academic analysis but nonetheless finds appreciative academic audiences and in some cases enjoys the blessing of university administrations eager to receive funding from Gulf states and/or to avoid confronting inconvenient truths of the contemporary condition. ${ }^{30}$ For instance, at a recent gathering at Yale University, a group of historians of French society concluded that Jihadist antisemitism should really be understood as a metaphor used for rhetorical and political impact. None of the scholars in question were students of Arabic, the Middle East, Islam, contemporary political or social movements, or contemporary or postHolocaust antisemitism. However, this did not stop them from adopting a position that would no doubt be welcomed by their institutions and gatekeepers. One director of a research center on antisemitism admitted to friends that his hands were tied and that he had to keep to this line. ${ }^{31}$

It is in this institutional and political context that Yale University's Associate Provost addressed the opening session of the YIISA conference and managed to stun many of those in attendance, including those who were well aware of the various hurdles to the study of contemporary antisemitism within the academy. In her opening remarks, the Associate Provost, explicitly warned the participants not to allow the conference to descend into a promotion of Islamophobia, thereby reinforcing a common stereotype

28 For a clear example of this sort of conflation, see Joseph Massad, "Palestinians, Egyptian Jews and propaganda," Aljazeera, January 7, 2013.

29 A good example of this phenomenon is Paul Gilroy's book, Between Camps: Nations, Cultures and the Allure of Race (2001), which begins with a heavily nostalgic and sympathetic look at the Jewish refugees that fled Nazi Europe and arrived in the London cityscape of Gilroy's childhood. It seems uncourageous, and is reflective of a general tendency within the academy, to condemn the horrible racist antisemitism of an era past while turning a blind eye to contemporary manifestations.

30 See Alex Joffe, "Follow the Money," Jewish Ideas, March 2, 2011; Ben Cohen, "Scholarship and Antisemitism at Yale," Jewish Ledger, Hartford, Connecticut, March 28, 2012.

31 Paula Marantz Cohen, "The New Antisemitism," The Smart Set, Drexel University, October 2012, available at: <http://thesmartset.com/article/article10181202.aspx>. 
associated with those studying contemporary antisemitism. It seems incongruous that the Associate Provost - and by extension the university administration-deemed it necessary to issue such a warning to a gathering of some of the world's most important and respected scholars on antisemitism and other forms of discrimination. Many of those in attendance viewed this as an example of the power of contemporary antisemitism, on the grounds that no other academic gathering on comparable forms of discrimination would be welcomed in this manner. ${ }^{32}$ In fact, it appears that Yale University's Jackson Institute was happy to invite Iranian President Mahmoud Ahmadinejad to speak to a group of Yale students just a month after the conference, in September 2010, without issuing a similar caveat. ${ }^{33}$ Finally, as the conference was entering its last day, without citing any specific evidence, the PLO Ambassador to Washington DC, Maen Rashid Areikat, and a network of Muslim Brotherhood affiliated student activists accused the conference of being Islamophobic. ${ }^{34}$ Soon afterwards, they began to attack YIISA itself as a platform for Islamophobia, which ultimately led to its demise. ${ }^{35}$ These events represent a key failure of academia in the face of political pressures, both domestic and foreign. ${ }^{36}$

32 As Ryan notes, there is a tendency to blame the victim in the politics of discourse. See William Ryan, Blaming the Victim (Vintage, New York 1971). Despite the complexities of Middle East politics, there is one particular social movement that clearly does not accept the other, yet some observers still find it difficult to critically assess and condemn its ideology.

33 See Sam Greenberg, "Relating to Iran, in seminar and in person," Yale Daily News, September 27, 2010, available at: <http://yaledailynews.com/blog/2010/09/27/relating-to-iran-in-seminar-andin-person>. In addition, the Jackson Institute hosted scholars with connections to the Iranian Revolutionary Regime, as well as Judge Richard Goldstone, at the invitation of Yale professor Ian Shapiro, an advocate of the Obama Adminstration's failing policy of "containment" of radical Islamism. See Michael Widlanski, Battle for Our Minds: Western Elites and the Terror Threat (Simon and Schuster, New York 2012).

34 See Josh Rogin, "PLO representative accuses Yale of supporting 'hate mongering,'” Foreign Policy, August 31, 2010; Abby Wisse Schachter, "Yale's latest gift to antisemitism," New York Post, June 7, 2011; "PLO Envoy Slams Yale for Antisemitism Conference," JTA, September 3, 2010, available at: <http://www.jta.org/news/article/2010/09/03/2740789/plo-envoy-slames-yale-for-antisemitism-conference>. See also Philip Weiss, "Yale conference on antisemitism targets Palestinian identity, self-hating Jews and anyone who criticizes Israel," Mondoweiss.net, August 25, 2010. This is an example of a blog that demonizes the conference without reference to the facts and also quotes people who openly incite to destroying Jews and Israel as expert sources. (See YouTube videos and writings by Charlotte Kates and Yaman Salahi).

35 Significantly, the head of Yale University's Public Relations Department, Charles Robin Hogen, was active in making statements to the media supporting YIISA's closure. Some of these statements were later found to be incorrect. See Abby Wisse Schachter, "Yale's latest gift to antisemitism," New York Post, June 7, 2011. Interestingly, Hogen introduced the fact and bragged about his close association with former PLO member Professor Rashid Khalidi at YIISA meetings. Hogen also stated in these meetings that he was at a point in his career where he did not need to promote projects he found distasteful, such as the antisemitism conference. In a fascinating twist, I recently came across materials that show that in the 1990s Hogan was the Vice President of Hybridon Inc. Days after the 9/11 attacks, investigators discovered that the Bin Laden family owned part of Hybridon. Hogan now works for Robert Woods Johnson. See Hogen's professional associations at: $<$ http://www.prweekus.com/johnson-foundation-names-hogen-vp/article/233952>; and a Harvard Crimson article pertaining to Hybridon's political and terror connections at: $<$ http://www.thecrim son.com/article/2001/9/27/local-company-distances-itself-from-bin>.

36 See Adam Brosky, "Yale's antisemitism whitewash," New York Post, July 7, 2011; and Walter Reich, "Saving the Yale Antisemitism Institute," Washington Post, June 13, 2011. 
The fact that YIISA's detractors could level such accusations in a prestigious Ivy League environment without providing any proof, or even attempting to document any discriminatory speech or providing any critique of the papers or academic presentations by leading scholars, ${ }^{37}$ is testament to the contemporary state of antisemitism in the academy and beyond.$^{38}$ It also points to the urgent need for a "critique of the critique" and the need to create an interdisciplinary critical framework for the study of contemporary antisemitism in relation to ideology and power relations. This would be a difficult task for scholars who are concerned about maintaining the institutional and cultural status quo and obtaining professional appointments and acknowledgement. The current intellectual and institutional void, which also encompasses a general disinclination to contemplate Islamist antisemitism and the Islamism in general, enables many to continue speaking of an Arab Spring when there are many indications that it is turning into an Islamic Winter. ${ }^{39}$ Any assessment of the region that does not address the global implications of radical political Islamism and antisemitism is fatally flawed and serves the reactionary forces by squashing analysis and debate at a key moment in Middle Eastern and global history. The reality is that these reactionary forces are gaining power, and they are doing so with the tacit or, in some cases, vocal support of "useful idiots" in the academy and the media. Paradoxically, the current refusal to explicitly oppose the rise of such forces, which are diametrically opposed to the basic human rights and democratic principles, due to a postmodern and/or post-colonial reluctance to hold them to Western standards is no less paternalistic than previous Western interventions in the region.

$* * *$

Daniel Sibony, the French philosopher, provides insights into the above-mentioned attitudes, which appear to have taken hold in many elite academic institutions in the West. ${ }^{40}$ In fact, Sibony contends that deep down those who insist on ignoring Islamism and its reactionary agenda are actually anti-Muslim themselves. The silencing of scholars and

37 In fact, this prompted leading scholars from around the world to write to the President of Yale University defending the conference against these unfounded allegations. In particular, many scholars signed a letter comparing the contemporary study of antisemitism by YIISA to the groundbreaking work of Yale's historians on the issue of slavery written in the 1950s. Thousands of letters from concerned parties were sent to Yale protesting the closure of YIISA one year later.

38 See Alan Dershowitz, "Yale's Distressing Decision to Shut Down Its Initiative for the Interdisciplinary Study of Antisemitism," Huffington Post, June 11, 2011. Dershowitz contends that a research center at Yale University has never been closed down on the basis of a confidential report, as in the case of YIISA. In "Yale's Jewish Quota: The University's Shameful Decision to Kill Its AntiSemitism Institute," Slate Magazine, July 1, 2011, Ron Rosenbaum examines how the conference formed the beginning of the end for YIISA, due to its insistence that aspects of antisemitism throughout the world, including the Middle East, would be examined at the conference despite warnings from the administration not to do so. According to Rosenbaum, this is essentially a new form of a Jewish quota, namely one that distinguishes between acceptable and unacceptable Jews. Writing in the New York Post, Neil Kressel claims that the accusations leveled at YIISA were baseless and never substantiated. See Neil Kressel, "Yale's Cowardice," New York Post, June 11, 2011.

39 In The Unloved Dollar Standard: From Bretton Woods to the Rise of China (Oxford University Press 2012), economist Ronald McKinnon documents how money-flows from the US cause cyclical bubbles in global commodity prices, including food, "so much so that the so-called Arab Spring of 2011 could be interpreted as just a food riot."

40 Daniel Sibony, Freud, Edward Said and Israel (forthcoming). 
human rights activists who are concerned about antisemitism and human rights in Middle Eastern societies is a manifestation of a deep fear, or phobia, of the Islamic world. This fear, which is combined with guilt over the West's colonial legacy in the Middle East, is powerful. ${ }^{41}$ As a result, there is a tendency in certain circles to tolerate and justify reactionary Islamic attitudes, including sexism, homophobia, and antisemitism, despite their own liberal views. ${ }^{42}$ It is thus more convenient to blame the Jews for the stalemate in the Middle East and other related problems. Sibony traces this to the colonial mentality of not expecting the peoples of the Middle East and other parts of the world to adhere to the same criteria of human rights and civility as the "civilized" West. He also points out that those who continue to highlight these contradictions and dangers eventually come to be perceived as the problem and are targeted instead. ${ }^{43}$

Sibony goes further, stating that there is an emerging fascination in the West with the genocidal antisemitic narrative of radical Islamism as expressed by the Iranian regime, the Muslim Brotherhood, and other Salafists. ${ }^{44}$ In a similar vein, Colin Shindler argues that the growing red-green alliance has come to see the displaced and marginalized members of the Islamic world as the new proletariat, who deserve Western liberal support and admiration. Anyone perceived as being critical of the new Islamic proletariat is immediately branded a reactionary. ${ }^{45}$ In this intellectual climate, voices condemning brutality, anti-democratic practices, sexism, homophobia, opposition to minority rights, and other violations of universal human rights are silenced, while expressions of genocidal antisemitism are dismissed as poor translations and/or hysterical rhetoric fashioned by the Zionist defenders of Israel. ${ }^{46}$ This is what makes the task at hand,

41 An example of the manifestation of this fear occurred when Yale sociologist Jeffrey Alexander, speaking on National Public Radio (NPR), compared the work of YIISA to that of the Black Panthers. Such an irrational, ahistorical, and reductionist comment pertaining to the African American condition and to the complex issues of both racism and antisemitism provides an insight into the sort of hurdles that are prevalent in the academy with regard to this subject. "Yale Shuts Down Antisemitism Program," National Public Radio, June 17, 2011.

42 This may help to explain why, at a meeting called for by the Associate Provost days before the conference, I was told not to invite any scholars or organize events that were critical of Middle Eastern society or Islam. Echoing the policy mantra, she told me that we must "engage" Islam. I informed here that YIISA events were not critical of Islam but that YIISA was examining antisemitism throughout the world and that it was analyzing Islamism as it would any other social movement. It is also worth noting that there seemed to be a certain amount of fear within Yale's administrative ranks in this regard. A year earlier, in 2009, in the face of threats, Yale University Press refused to publish cartoons depicting the Prophet Muhammad in a book by Jytte Klausen discussing the publication of those very cartoons in 2006, which led to global riots in which at least 200 people were killed. See Patricia Cohen, "Yale Press Bans Images of Muhammad in New Book," New York Times, August 12, 2009; Jeffey Herf, "Why Did Yale Close, Then Open, A Center on Antisemitism?" The New Republic, July 5, 2011.

43 Daniel Sibony, L'Enigme antisémite (Seuil 2004). See also Daniel Sibony, "The Essence of Antisemitism: Is It Too Simple to Be Understood?" ISGAP Seminar Series, McGill University, October 16, 2012.

44 Daniel Sibony, "The Essence of Antisemitism: Is It Too Simple to Be Understood?" ISGAP Seminar Series, McGill University, October 16, 2012 and Harvard University, October 17, 2012.

45 Colin Shindler, "The Left Sees Islam as the New Proletariat," New York Times, October 28, 2012.

46 This helps to explain why, at a recent seminar at Clark University's Strassler Center for Holocaust and Genocide Studies, David Feldman of Birbeck College, London, felt able to claim that YIISA was in fact the long arm of Israeli intelligence within the academy. Several of those in 
namely to produce high-caliber scholarship and effective policy development and analysis for dealing with contemporary antisemitism - in particular its potentially genocidal variety - all the more challenging but also all the more urgent.

The crisis of modernity refers to the crisis of capitalism itself. Regardless of one's definition, the crisis is causing problems at local and global level and has become a key aspect of the contemporary condition. Institutions that play a key role in society, especially the state, are under increasing pressure. The crisis is affecting everything from the core to the periphery. Those in the periphery are experiencing high levels of socio-economic, political, and even cultural marginalization. In some areas of the world, the economic and political crisis in is so severe that it is causing failing and even failed states. Several states in the Middle East and North Africa, as well as several other Islamic states, are currently in this predicament. ${ }^{47}$ When such states fail, marginalization increases. The resulting power vacuum is increasingly being filled by radical Islamism, whose adherents, like those who follow neo-liberalism, actually detest the state, perceiving it as a vestige of the colonial era and Western imperialism. In many cases, the political actors and interests that are rising to power subscribe to ideological worldviews that are also extremely hostile toward Jews.

In the context of the conference title, the term "modernity" refers to the processes that led to the emergence of the specific and distinctive characteristics of modern society. In this context, the concept of "modernity" does not simply refer to a phenomenon of contemporary origin. It posses an analytical and conceptual value that embodies the defining characteristics of modern societies. According to Stuart Hall, these characteristics include:

(1) The dominance of secular forms of political power and authority and conceptions of sovereignty and legitimacy, operating within defined territorial boundaries, which are characteristic of the large, complex structures of the modern nation-state.

(2) A monetarized exchange economy, based on the large-scale production and consumption of commodities for the market, extensive ownership of private property and the accumulation of capital on a systemic, long-term basis. [...]

(3) The decline of the traditional social order, with its fixed social hierarchies and overlapping allegiances, and the appearance of a dynamic social and sexual division of labor. In modern capitalist societies, this was characterized by new class formations and distinctive patriarchal relations between men and women.

(4) The decline of the religious world-view typical of traditional societies and the rise of a secular and materialist culture, exhibiting those individualistic, rationalist, and instrumental impulses now so familiar to us. ${ }^{48}$

attendance demanded that he substantiate his accusation. He could not. The idea that one cannot engage in the scholarly examination of contemporary antisemitism without having a conspiratorial agenda, which is associated with notions of dual loyalty, is a powerful antisemitic canard with a long pedigree, especially in European discourses.

47 See "The 2012 Failed States Index," An Eighth Annual Collaboration between Foreign Policy and the Fund for Peace, available at: <http://foreignpolicy.com/failed_states_index_2012_interactive $>$.

48 Stuart Hall, "Introduction," in Stuart Hall et al., eds., Modernity: An Introduction to Modern Societies (Blackwell Publishers 1996) p. 8. 
The emergence of modern societies was spurred by new intellectual movements that developed during the Reformation, the Renaissance, the Scientific Revolution of the seventeenth century and the Enlightenment of the eighteenth century. The transformation of Europe's intellectual, philosophical, and moral framework was significant and played an important part in the formation of modern societies as encapsulated by capitalism and the rise of the nation state. In addition, Hall contends that the construction of cultural and social identities is an important aspect of the formation process. This then plays a key role in creating "imagined communities" and symbolic boundaries that define who belongs and who is excluded as the "Other."49

In the context of the YIISA conference, the "crisis of modernity" refers to the current breakdown of the political and economic system. However, this crisis also operates at a philosophical level, raising issues that are just as important as economic and political uncertainty. In fact, the uncertainty created by the crisis is eroding the moral and ethical rudder of Western institutions by creating a philosophical vacuum that is being filled by the moral relativism of postmodernism.

On one level, modernity offered a different vision of humanity, society, and the universe, but it also required a narrative to establish the legitimacy of its vision. This narrative constructed an image of the "Other," living in darkness and irrational ignorance due to his so-called primitive religious beliefs. In contrast, the so-called Enlightened thinkers and scientists succeeded in liberating man from his material and philosophical poverty and placed him on the path to progress and perfection. ${ }^{50}$ This narrative, which was dominant in seventeenth and eighteenth century Europe, also provided the foundations for modernity's racism, slavery, and - as some argue-even the Holocaust.

The "crisis of modernity," then, is the recognition of the weakness of this narrative and the uncertainty of everything that has emerged from it, including the existing social order, ethical standards, and even our perceptions of ourselves. In this postmodern moment of uncertainty and competing relativist narratives, thinkers are prevented from thoroughly examining and speaking out against the forms of discrimination openly advocated by radical reactionary social movements, including but not limited to antisemitism, that challenge notions of equality and robust citizenship. ${ }^{51}$ Another result of the "crisis of modernity" is the emergence of the aforementioned red-green alliance, which is gaining ground among scholars, practitioners, and activists, as well as within the political establishment.

Much of the scholarship on antisemitism is descriptive in nature, especially concerning its contemporary manifestations. However, there is also a need to analyze antisemitism

$49 \mathrm{Id}$.

50 Id.

51 Leo Strauss, a strong critic of modernity, attributed modernity's intellectual degradation to the influence of several Enlightenment philosophers in the history of political thought who radically broke with classical political thinking. Strauss believed that, in doing so, these thinkers either directly or indirectly contributed to the emergence of historicism and positivism, and he held these movements accountable for modernity's relativism, nihilism, and moral and intellectual demise. See Jens Olesen, "The Crisis of Modernity and Its Interpretive Significance: Leo Strauss on Reading Political Philosophy," paper presented at the 14th International Graduate Conference in Philosophy, University of Essex, May 28, 2011. 
in the context of other processes - socio-economic, political, cultural, and ideologicaland the impact of globalization. Few scholars contextualize their studies in this manner. There is therefore a need to combine empirical and conceptual analysis of antisemitism within an interdisciplinary framework. The contemporary condition, which is characterized by the crisis of modernity, the processes of globalization, which are governed by a neo-liberal approach, the weakening of the state, the emergence of radical political Islamism as an effective social movement, the reluctance of Western intellectuals to critically engage these processes, and the re-emergence for the first time since the Holocaust of a deadly form of antisemitism, requires the development of a creative, interdisciplinary, critical approach within a cooperative research entity to begin to assess this phenomenon in all its manifestations and implications. This is especially true at a time when-for all sorts of reasons-such an entity has many opponents.

Globalization has a direct bearing on contemporary antisemitism. During the last several decades, nationalism and new forms of identity politics have exacerbated existing social, economic, and political cleavages. The causes of this emerging crisis include the extension of global competitive markets and the effects of structural adjustment, the intensification of socio-economic inequalities, the blurring of international and domestic political conflicts, and the world-wide escalation of adversarial "identity politics." ${ }^{52}$ The extension of information technologies and travel possibilities has created a new network of "global spaces" within the interstices of metropolitan life across continents, inhabited by a growing coterie of transnational professionals and specialists. From the perspective of this high-rise corporate economy and corporate culture, the city down below appears to be inhabited by immigrant populations competing for low-wage jobs in an increasingly informalized urban economy, as the state retreats from its welfare functions. The combined economic and political imperatives of globalization seem to sweep away particularities of time and place to generate common outcomes everywhere: growing ethnic racial and cultural heterogeneity, coupled with social and spatial polarization.

At the most general level, it is possible to think of globalization in terms of movement and circulation, a complexity of criss-crossing flows: some of it capital and trade, some of it people, and some of it signs, symbols, meanings, and myths. A common thread which runs through the existing body of literature is the idea that such flows and mobility across space have accelerated, speeded up, or gained a new momentum in the contemporary era, captured in such key phrases as "time-space compression," 53 "timespace distantiation," ${ }^{54}$ and "intersecting scapes." 55 Thus the concept of globalization does not imply a shift from one period to another in the form of an historical rupture, as do other encompassing terms most frequently used to describe contemporary metropolitan experience, namely post-Fordism ${ }^{56}$ and postmodernity. ${ }^{57}$ Rather it denotes an

52 Charles Small, "Creating National Identity and Otherness: Canada and the First Nations," in Olufemi Vaughan and Charles Small, eds., Globalisation and Marginality: Essays on the Paradoxes of Local and Global Forces (Sefer Academic Press, Ibadan, Nigeria 2007).

53 D. Harvey, The Condition of Postmodernity (Basil Blackwell, Oxford 1989).

54 A. Giddens, The Consequences of Modernity (Polity/Blackwell, Cambridge 1990).

55 A. Appadurai, Globalization (Duke University Press, Durham, N.C. 2001).

56 A. Amin, Post-Fordism: A Reader (Blackwells, Oxford 1994).

57 E. Soja, Postmodern Geographies: The Reassertion of Space in Critical Social Theory (Verso, London 1989); S. Watson and K. Gibson, eds., Postmodern Cities and Spaces (Blackwells, Oxford 1995). 
intensification and stretching out of movements and flows, as captured for instance in Giddens's definition of globalization as "the intensification of world-wide social relations which link distant localities in such a way that local happenings are shaped by events occurring many miles away and vice versa." 58

Some social groups initiate flows and movement, while other do not; some are more on the receiving end of it than others; some are effectively imprisoned by it. There is thus a dimension of movement and circulation; there is also a dimension of control and initiation. The ways in which different social groups are re-inserted into, placed within, and seize upon these flows, which are themselves differentiated, can both reflect and reinforce existing power relations; it can also undermine them. What does not follow from the considerations above, and yet continues to inform much of the literature on global flows, is the social imaginary of a borderless world. Inherent to the concept of global flows, differentiated and differentiating, is the capacity to transgress taken for granted boundaries between nation states, between racial, ethnic, and gender groups, and between the public and private spheres. This does mean, however, an increasingly order-less world, one in which boundaries have lost their meaning. On the contrary, borders have become the locus of struggles among a variety of social actors, mobilized to reassert or redefine their boundaries vis-à-vis other relevant actors, and translate onto the space of the metropolis.

Globalization divides as much as it unites. Alongside the emerging planetary dimensions of business, finance, trade, and information flows, a localizing, space-fixing process is set in motion. Between them the closely interconnected processes sharply differentiate the existential condition of entire populations and of various segments of each one of the populations. What appears as globalization for some means localization for others; signaling a new freedom for some, upon many others it descends as an uninvited and cruel fate. Some of us become fully and truly global; some are fixed in their locality. Being local in a globalized world is a sign of deprivation and degradation. An integral part of the globalizing process is progressive spatial segregation, separation, and exclusion. Neo-tribal and fundamentalist tendencies, which reflect and articulate the experience of people on the receiving end of globalization, are as much legitimate reactions to globalization as the widely acclaimed hybridization of top-culture-the culture at the globalized top. There is a break down in communication between the globalized elites and the ever-more localized rest. ${ }^{59}$

It is in this context that contemporary antisemitism emerges. In a real sense, Israel is in the middle of a region in which societies are experiencing critical levels of marginalization, and in some cases collapse, threatening social cohesion and further complicating international relations. As mentioned above, globalization-through migration, trade and business, and advances in technology and telecommunications-is connecting people as never before, but it is also dividing them as much as it unites them. In the

58 A. Giddens, The Consequences of Modernity (Polity/Blackwell, Cambridge 1990).

59 Charles Small, "Creating National Identity and Otherness: Canada and the First Nations," in Olufemi Vaughan and Charles Small, eds., Globalisation and Marginality: Essays on the Paradoxes of Local and Global Forces (Sefer Academic Press, Ibadan, Nigeria 2007). 
midst of these processes, contradictions, and emerging cleavages, antisemitism is once again flourishing in the form of the demonization of Israel and, by extension, Diaspora Jewry, with its real and supposed associations with the State of Israel. ${ }^{60}$ During five years of interdisciplinary programming and research projects conducted at the highest levels of scholarship, several YIISA scholars examined the emerging socio-economic, political, and cultural vacuum that is being filled by the burgeoning social movement of radical political Islamism. This movement embodies the most pernicious forms of antisemitism, including a consistent call for, and incitement to, genocide against the Jewish state, consistent with its ideological and religious worldview. Many scholars and policy makers do not recognize or acknowledge these developments. It is within this context that Israel is emerging as the "Jew among nations," finding itself geographically, politically, and metaphorically in the center of this process, as well as on the frontline of a conflict over basic relations of the state and notions of democracy. Like the Jews of Europe during the interwar period, the Israel and-perhaps more so-Jewish people in Diaspora communities around the world will find themselves separated from the elites on one side and the working classes on the other. They will be more separated politically, culturally, and economically in the middle of competing forces as the crisis of modernity continues to evolve and its manifestations deepen. As Bernard-Henri Lévy contends, it is the role of the intellectual to shed light where there is darkness. It is the study of contemporary antisemitism and the struggle to develop social policies that will promote human dignity and respect for all that is once again an urgent calling for scholars. ${ }^{61}$ With this in mind, it is important to consider the following three points:

(1) The failure to recognize antisemitism studies as a valid academic discipline contributes to the ongoing mood of apologetic lethargy concerning this long-lasting prejudice. Now more than ever, there is a need for a vibrant, critical, open interdisciplinary research center to develop research projects and interdisciplinary curriculums. Policy and policy development are respected areas of study that need to be included in the area of contemporary antisemitism studies. Those who dismiss this as advocacy are pushing an regressive political advocacy agenda of their own.

(2) The failure of academia to assert its independence from funding sources and government influence in the study of human rights and efforts to combat hatred is a failure worthy of research in itself, as it goes to the heart of free debate and democratic principles and practice.

(3) Antisemitism is a major issue in the study of globalization, modernism, and postmodernism and also needs to be acknowledged as a legitimate issue in Middle Eastern studies. The study of contemporary antisemitism from an interdisciplinary perspective is crucial to scholarship, policy, and the protection of human rights, human dignity, and democratic principles, especially in these times of silence.

60 It is important to consider the impact of social media and information technology on the dissemination of its ideas, discourse, and political culture, especially in the Middle East. This impact is like a double-edged sword, since it encompasses an utopian liberating effects but also empowers reactionary forces. In this context, it is interesting to note that certain hateful images of Jews with origins in European antisemitism are being "beamed" into Europe for the first time in many decades from the Middle East.

61 See Bernard-Henri Lévy, Left in Dark Times: A Stand Against the New Barbarism (Random House 2009). 
As Ruth Wisse has summarized the issue with insight and power: "Jews in democratic societies are not merely the proverbial canaries sent into the mine shaft to test the quality of the air: they function rather as the kindling used to set the system aflame. Why stop at the Jews?" In other words, the study of antisemitism is not a parochial matter, but a complex and explosive phenomenon that is bound up with matters of human rights, the protection of democratic principles, and citizenship, as well as notions of dignity. In the contemporary context of globalization, combined with the rise of reactionary social movements, we must not only examine and come to understand these complex processes as they relate to antisemitism: it is also incumbent upon us to develop approaches to safeguard and solve these attacks against all humanity.

This volume presents a selection of the papers presented at the "Global Antisemitism: A Crisis of Modernity" conference organized by YIISA in August 2010. It is one of five volumes reflecting the interdisciplinary nature of the conference as well as the diverse nature of the subject of antisemitism in general.

Volume I includes papers that approach antisemitism from a wide range of conceptual perspectives and scholarly disciplines. Volume II deals with matters of antisemitism and the intellectual environment. The papers in this volume focus on the treatment of Israel in the media and the study of antisemitism in the academy. Volume III examines the manifestations and impacts of antisemitism in various regional contexts. Some of the papers focus on historical cases, while others focus on recent or contemporary matters. Volume IV on Islamism and the Arab world examines a form of antisemitism that has become especially virulent in recent times. It is also a form of antisemitism whose origins and manifestations are perhaps less well-known to academics and policy-makers due to the supposedly controversial nature of this topic. This volume includes papers from some of the leading experts in this area. Volume $\mathrm{V}$, finally, comprises various "reflections" that were presented at the conference by a number of well-respected observers, academics, and practitioners. They provide insightful observations and important analysis but are not presented in the form of classic academic papers.

These volumes will be of interest to students and scholars of antisemitism and discrimination, as well as to scholars and readers from other fields. Rather than treating antisemitism merely as an historical phenomenon, they place it squarely in the contemporary context. As a result, the papers presented in these volumes also provide important insights into the ideologies, processes, and developments that give rise to prejudice in the contemporary global context. 



\title{
Antisemitism and Anti-Zionism in the "New" South Africa: Observations and Reflections
}

\author{
Milton Shain*
}

Almost two years ago, I was struck by two virtually concurrent news headlines: the weekly South African Jewish Report led with the headline "Low anti-Semitism in SA - but don't be complacent" and a week later I received a piece from the South African Zionist Federation in Israel entitled "South Africa almost tops anti-Semitism charts". The South African Jewish Report article was based on a talk by a senior researcher at the South African Jewish Board of Deputies, David Saks, who reported that South Africa had a relatively low rate of antisemitism: it was 10 times higher in the UK, France and Argentina, 15 times higher in Australia and 20 times higher in Canada and Germany.

The figures had been calibrated in terms of antisemitic incidents. The low number was attributed to dormant far-right white organizations, coupled with an anti-racist ethos in post-apartheid South Africa and buttressed by South Africa's so-called chapter nine institutions, such as the Human Rights Commission, and the values embedded in the Constitution. ${ }^{1}$ On the other hand, the South African Zionist Federation based their claim that "South Africa almost tops anti-Semitism charts" on a "Pew Global Attitudes Survey of 2008", which found that South Africans, along with Spaniards, Mexicans and Brazilians, held some of the most negative views of Jews outside of the Muslim world. According to the survey, 46 percent of South Africans harboured unfavourable views of Jews and of those 46 percent two-thirds disliked Jews in the extreme. A much lower figure of 11 percent was recorded in Australia - which had more incidents. ${ }^{2}$

What one has here are measures by incidents on the one hand and measures by attitudes on the other. What should we make of the differences? Certainly we should not discount the role of ideas, especially in specific political contexts. In South Africa, for example, a serious "Jewish Question" was experienced in the 1930s and 1940s when - at a time of heightened Afrikaner ethno-nationalism - hostile ideas about the Jews were transformed by the radical Afrikaner white right into programmatic antisemitism. ${ }^{3}$

* Professor, Department of Historical Studies, and Director, Isaac and Jessie Kaplan Centre for Jewish Studies and Research, University of Cape Town.

1 South African Jewish Report, 19 September 2008.

2 See <http://supernatural.blogs.com/weblog/2008/09/south-africa-al.html>.

3 See Patrick J. Furlong, Between Crown and Swastika: The Impact of the Radical Right on the Afrikaner National Movement in the Fascist Era (Witwatersrand University Press, Johannesburg 1991) and Milton Shain, The Roots of Antisemitism in South Africa (University Press of Virginia and Witwatersrand University Press, Charlottesville, London and Johannesburg, 1994). 
Today, this radical white right - with its conspiratorial views of Jewish wealth, power and influence - has effectively disappeared. In its heyday in the 1930s and early 1940s, movements such as the Greyshirts, the Ossewa Brandwag and the New Order - all clearly inspired by Nazism - were a serious menace. But these ideas eroded rapidly after the Second World War. Classic Jew baiting was restricted to a fringe ultra-right element, although the apartheid government did question Jewish loyalty in the early 1960s when Israel supported the African bloc in the United Nations, and it did, from time to time, remind Jews of their disproportionate involvement in anti-apartheid activities. ${ }^{4}$ In the "new" democratic South Africa, however, the white right is of marginal concern. On the other hand, the "black" or African majority has shown some proclivity towards antiJewish prejudices. While historically these victims of apartheid struggled to overthrow white minority rule and certainly never focused specifically on Jews when articulating grievances and aspirations, studies from the early 1970s show that the black population is not immune to anti-Jewish prejudice. ${ }^{5}$

In recent times, industrial protests have occasionally identified specifically "Jewish capitalists" and antisemitic placards have been displayed at a number of strikes around the country. In the wake of the 2009 Gaza War, anti-Zionist protests led by the labour union federation COSATU raised the possibility of targeting specifically Jewish businesses. In some circles, Jewish loyalty to South Africa is questioned. But on the whole the black African population cannot be accused of widespread antisemitism. When it comes to the Muslim population - less than 2 percent of the total population but relatively influential - things are different. Many in this community share conspiratorial ideas of the old far-right white, manifested in the letter columns of the daily press and articulated in radio talk shows. Although the focus of their rhetoric is Zionism, their language often reveals classic anti-Jewish motifs and tropes. For some critics, at least, Jews or Zionists have become diabolically evil. ${ }^{6}$ This was best captured in the comments made by South Africa's deputy foreign minister, Fatima Hajaig, at an anti-Zionist rally in January 2009:

They [Jews] control [America], no matter which government comes into power, whether Republican or Democratic, whether Barack Obama or George Bush... Their control of America, just like the control of most Western countries, is in the hands of Jewish money and if Jewish money controls their country then you cannot expect anything. ${ }^{7}$

Holocaust denial has also crept into Muslim anger. In 1996, Radio 786, a Muslim radio station, had to apologize for airing an interview with Dr Ahmed Huber, who spoke of the "Holocaust swindle", and in May 1998 the same radio station interviewed Dr Yaqub Zaki who, besides claiming that the "million plus" Jews who died in the Second World

4 See Gideon Shimoni, Jews and Zionism. The South African Experience 1910-1967 (Oxford University Press 1980) ch. 8 passim.

5 See, for example, Melville Edelstein, What Do Young Africans Think? (South African Institute for Race Relations, Johannesburg 1972).

6 See Milton Shain and Margo Bastos, "Muslim Antisemitism and anti-Zionism in South Africa since 1945", in Antisemitism International 2006, Nos. 3-4 (Vidal Sassoon Centre, The Hebrew University of Jerusalem, Jerusalem 2006).

7 See $<$ http://commentary.co.za/archives/2009/01/29/fatima-hajaigs-anti-semitism>. 
War had died of infectious diseases, spent much of his time engaged with elaborate Jewish conspiracies. Shortly after the Cape Town Holocaust Centre was established in 1998, a leading Muslim newspaper recommended readers acquaint themselves with the work of Arthur Butz and other "denialists". ${ }^{8}$ It was thus no surprise that the Protocols of the Elders of Zion went on sale at the World Conference Against Racism in Durban in 2001.

Yet despite these developments, one cannot talk of classic antisemitism having serious traction in South Africa today. The public discourse is inclusive and non-racial, as opposed to exclusivist, as it was in the 1930s when the country had - as mentioned above - a serious "Jewish Question". Pluralism, multiculturalism, religious tolerance and "rainbowism" - the very antithesis of ethno-nationalism - is celebrated in South Africa. Cultural rights and religious freedom are enshrined in the new South African Constitution. This has the potential to take the sharpness out of ethnic conflict while militating against antisemitism. Of course, in some countries, multiculturalism has led to a dangerous identity politics, especially on the part of Muslims. So far this has not been the case in South Africa. Muslims were a part of "the struggle" for generations and appreciate the new constitutional order. One also needs to note the condemnation of antisemitism by political leaders in recent years. An apology from the deputy foreign minister, Fatima Hajaig, following her tirade is not without significance. She was not reappointed in Jacob Zuma's cabinet when he took office in 2009.

Certainly, the climate for opposing classical antisemitism in South Africa today built upon the ANC's historic opposition to racism - is more favourable than it has been in the past. When it comes to anti-Zionism, however, things are markedly different. In particular, it is noteworthy that hostility penetrates into the highest echelons of government. For many, the very notion of an allegedly exclusivist and colonialist "Jewish state" is anathema. This worldview has a long history, deeply embedded in "the struggle". As far back as 1955, the ANC's Freedom Charter stressed the unity of South Africa and opposed the politics of ethnicity or "tribalism". Intellectually, liberation was underpinned by a critique of the dangers of ethnic mobilization as evident in the Afrikaner national movement.

These ideas were further reinforced from the 1960s by Marxian currents within the academy, both in South Africa and abroad. Scholars deconstructed ethnicity - neither "natural or immutable" in the words of Shula Marks and Stanley Trapido - while demonstrating how it was being manipulated and used in South Africa as a means to divide and rule, palpable in the apartheid project with its proposed puppet ethnic "homelands". 9 A broadly "third worldist" and anti-colonial Weltanschauung evolved among exiled and domestic activists. They took a decidedly dyspeptic view of the West, its support for the apartheid state and the Pretoria-Jerusalem axis that evolved from the early 1970s, a relationship recently explored by Sasha Polakow-Suransky in his book The Unspoken Alliance. ${ }^{10}$

8 Shain and Bastos, supra note 6, at pp. 24-25.

9 Shula Marks and Stanley Trapido, "The Politics of Race, Class and Nationalism", in Shula Marks and Stanley Trapido (eds.), The Politics of Race, Class and Nationalism in Twentieth Century South Africa (Longman, London and New York 1987).

10 Sasha Polakow-Suransky, The Unspoken Alliance. Israel's Secret Relationship with Apartheid South Africa (Pantheon Books, New York 2010). 
These ideas were fed by a growing anti-Zionist literature that demonized the Jewish state. In particular, Muslims acquainted themselves with this literature. Pained at the outcome of the Six Day War, buoyed by the "Zionism equals Racism" resolution of 1975 at the United Nations and radicalized by the Soweto uprising of 1976, a younger generation of Muslims were increasingly radicalized. They were further encouraged by the overthrow of the Shah in Iran in 1979 and the success of Khomeinism.

Although the Muslim voice carried little weight with most whites in apartheid South Africa, it is arguable that they added muster and substance to the broad left's position, including "white" progressives who began to voice their support for what they saw as the legitimate anti-colonial struggle of the Palestinian people. By the late 1980s, an increasingly radicalized "left" criticized Israel as an exclusivist apartheid state. At the United Nations, Dr Neo Mnumzama, the Chief Representative of ANC - still in exile at the time - put it bluntly: "The South African people have never approved of Zionism. They see parallels of apartheid in Zionism and therefore their struggle against apartheid automatically has overtones of anti-Zionism which is not the same thing as being antiJewish". ${ }^{11}$

These views were shared by Aubrey Mokoena, a senior member of the United Democratic Front, an internal wing of the ANC. Zionism, he maintained, was simply racism, "because Zionism says we close our ranks on an ethnic basis. We take care of the Jewish interests. If you are Jewish it's okay, if you are not Jewish, out."12 A former president of the "Africanist" Azanian Political Organization (Azapo), Ishmael Mkhabela, took a similar view, claiming that Zionism was a form of religious discrimination that was, in his view, the same as the racial discrimination faced by blacks in South Africa. ${ }^{13}$ This alleged exclusivity ran counter to the non-racial and inclusive outlook of the liberation movement, both exiled and domestic. With it went a sense of unease with a Jewish state and, as the Rev Frank Chikane, Secretary General of the South African Council of Churches, put it, "an easy sympathy" for the PLO. ${ }^{14}$ There is no doubt, said one prominent Soweto civic leader, Dr Nthato Motlana, in the 1980s, "that Black Africans tend to identify with the PLO... Let's be clear about this, there is a perception of the Israeli-Arab conflict as one of almost colonialism of a white race coming out of Europe."15

Such ideas have survived and are now a staple of trade union and progressive activism. In addition, the English-language media - largely owned since 1994 by the Irishman Tony O'Reilly's Independent Group - reinforced these positions. Columnists like Robert Fisk and John Pilger regularly poison a hostile anti-Zionist atmosphere.

When Yasser Arafat spoke in South Africa's parliament in 1998, he was applauded when he referred to Zionism as racism, despite the notion running counter to the ANC's stated position on the Arab-Israeli conflict, namely accepting a Jewish state alongside a Palestinian state. ${ }^{16}$ Even 9/11 did not temper hostility. On 23 October 2001, the minister of water affairs, Ronnie Kasrils, a communist Jew, a member of the ANC underground

11 Tzippi Hoffman and Alan Fischer, The Jews in South Africa. What Future? (Southern Book Publishers, Johannesburg 1988) p. 73.

12 Ibid., p. 34.

13 Ibid., p. 46.

14 Ibid., p. 22.

15 Ibid., p. 61.

16 Milton Shain, "South Africa", in American Jewish Year Book, Vol. 99, 1999, p. 415. 
for 30 years and a senior commander of its military wing, Umkhonto We Sizwe, read a statement on the Middle East in the National Assembly during a special Middle East debate that discussed the report of a fact-finding committee that had visited the Middle East. ${ }^{17}$

Kasrils and his ANC colleague Max Ozinsky, a member of the Western Cape provincial legislature, then circulated the statement - slightly amended - with a view to getting as many Jewish signatories as possible. The final declaration was launched on 7 December 2001 under the banner "Not in My Name". It was signed by only 284 Jews but had widespread support beyond the Jewish community, including the ANC and the media.

Kasrils has compared the discourse of "chosenness" in Zionism with "the way the Afrikaner trekkers also used it, the way many historical movements have done to advance the cause of a particular people. It's an exclusivity which gives rise to racism and all sorts of negative things." 18 This notion of exclusivity - manifest in the ethnonational state - has always raised problems for the radical left. It challenges a deep seated universalism. But, in addition, the apparent success of South Africa's so-called "miracle" further undermines the Zionist idea. That is to say, commentators increasingly ask why Israelis and Palestinians cannot follow the South African example and establish a single constitutional state, which includes Jews and Palestinians. They compare Zionists with apartheid ideologues of old and see Hamas and Islamic Jihad as demonized in much the same way as the apartheid government had demonized the ANC in exile. They argue that Israel - like the apartheid government - wants to cut a deal only with moderates like Mahmoud Abbas. ${ }^{19}$

In this context, support for a two-state solution is rapidly eroding. One well-known former liberal newspaper editor, Allister Sparks, repeatedly contends that such a solution is untenable. Israel's lack of will to remove the settlements coupled with demographic realities, he argues, has precluded this option. "Like South Africa's bantustan policy it was a nice idea in theory: to separate rival groups living in one country so that each can have its own national homeland sounds like a moral solution - provided the separation is fair and the homelands are viable."

In building his case, Sparks recalls how the apartheid planners had also denied demographic realities in their dream of a "white" South Africa. But eventually, he reminds us, they had to face the truth. Sparks' great source is the book One State Solution by Virginia Tilley, an American academic now resident in South Africa. "Would a negotiated settlement for a one-party state," ask Sparks, "not defuse the destructive antagonisms between Israelis and Palestinians as it has done in South Africa, and in doing so make Israel a much safer homeland for Jews than it is now?"20

Sparks continues to draw parallels between Israel and South Africa and sees the Israeli-Palestinian conflict through a South African prism. The fact remains, he argues,

17 See Joel B Pollak, The Kasrils Affair. Jews and Minority Politics in Post Apartheid South Africa (University of Cape Town Press and the Kaplan Centre for Jewish Studies, Cape Town 2009) p. 1.

18 Immanuel Suttner (ed.), Cutting Through the Mountain. Interviews with South African Jewish Activists (Viking, London 1997) p. 281.

19 See, for example, Allister Sparks, "Cutting a peace deal easier now", Cape Times, 16 November 2004.

20 "Israel's two state solution is dead", The Star, 21 September 2005. 
that many ethno-nationalisms grapple with the problem of other ethnic groups in their midst... The new South Africa has not required the forfeiture of the "Afrikaner homeland". I well remember the dark warnings, uttered from pulpit and platform, over more than half my working life, that "one man one vote" would mean the "national suicide" of the Afrikaner volk and that they would never, ever contemplate it. ${ }^{21}$

Sparks's views have wide resonance and reflect attitudes among the chattering class, particularly within a government that is informed by a mantra of non-racism, opposition to ethnic politics, a powerful anti-colonialism, support for the underdog and a particular understanding of South Africa's so-called "miracle", built upon respect for cultural and religious diversity.

Put simply, there is a general antipathy towards ethnic concerns. South African politics, notes Hermann Giliomee, a leading South African historian, is informed by "a dogmatic or intransigent universalism." "Its point of departure," he explains,

is that race or ethnicity as a principle of social organization is essentially irrational and ephemeral and that there is no need to make any concessions to it. What this boils down to is the unshakeable conviction that there is not much more to racial or ethnic identification than the legacy of apartheid classification. ${ }^{22}$

With this mindset, the Palestinian struggle is seen as a classic anti-colonial struggle. And the parallels with black resistance in South Africa are taken even further. Many believe that the Palestinians were offered "bantustans" at Camp David in 2000, akin to what the "homeland" leaders were offered under apartheid. This, they maintain, will replicate the historic migrant labour system so powerful in South African consciousness.

To use the late Tony Judt's term, for many South African elites, including radical Jews, Israel is an anachronistic ethnic state. ${ }^{23}$ Zionism as a Jewish liberation movement has receded into the mists of time; the term has become associated with exclusivism and expansionism. "It's a policy that to me looks like it has very many parallels with racism," explains Nobel Laureate Archbishop Emeritus Desmond Tutu. ${ }^{24}$ Tutu is widely supported in the electronic and print media. The late Anthony Holiday, a philosopher at the University of the Western Cape, went so far as to advocate outlawing the South African Zionist Federation. ${ }^{25}$

Such views have been maturing for decades and are inextricably linked to a specific South African past. While the ANC's commitment to multilateralism and the United Nations ensures support for a two-state settlement - for the time being at least - it seems to me that elites, driven and informed by activists, many of them Muslim, will continue to push for ties between Pretoria and Jerusalem to be cut.

Yet it needs to be noted that a Pew Global Project Attitudes Survey conducted in urban areas in South Africa in 2007 reported greater sympathy for Israel than for the Palestinians. The survey indicated that 28 percent of South Africans sided with Israel in the Israeli-Palestinian conflict as opposed to 19 percent with the Palestinians. Nineteen

21 "The boys who cried 'anti-Semite'", The Star, 6 October 2006.

22 Hermann Giliomee, "Manipulating the past", in Political Correctness in South Africa (South African Institute for Race Relations, Johannesburg 2000) pp. 93-94.

23 See "Israel: the Alternative", New York Review of Books, 23 October 2003.

24 Hoffman and Fischer, supra note 11, at p. 15.

25 "Patriotism of SA Jews undermined", Cape Times, 30 March 2004. 
percent sympathized with both the Israelis and the Palestinians. ${ }^{26}$ Perhaps this is because the majority of South African blacks are Christian, with a deep attachment to the so-called "Holy Land". It also needs to be said that the Muslim community is not monolithic. Many Muslims are progressive, emphasizing Islamic humanism and universalism; others, of course, are conservative or Islamist, at odds with religious pluralism and ecumenism.

But there is a broad anti-Zionism, shared, as noted above, by many in the highest echelons of government. There are repeated calls - especially from activist groups such as the Palestine Solidarity Committee and the Trade Union Federation - to break diplomatic and trade relations ties with Israel. Hamas is popular among many Muslims. In July 2010, a former minister of education, Professor Kadar Asmal, called on the world to deny legitimacy to Israel. "It is time to delegitimize this entity", he wrote, in the weekly Mail $\mathcal{E}$ Guardian while reflecting on the Goldstone Report and the Gaza Flotilla. ${ }^{27}$ The Thinker, an intellectual monthly founded by Mbeki's right-hand man, former minister in the presidency Essop Pahad, included vitriolic anti-Israel comment in its latest issue. ${ }^{28}$

Memories are short. The drama of the Jewish suffering in the diaspora and the rebirth of the Jewish state have receded into the distant past. Regular television footage of Israeli forces in the territories, interminable talk shows dominated by anti-Zionists and an outpouring of literature comparing apartheid South Africa to Israel, continue to undermine the idea of the Jewish state. For many elites in South Africa, Zionism is a 19th century ethno-national movement caught off-side in the 21st century.

26 Milton Shain, "South Africa", in American Jewish Year Book, Vol. 108, 2008, p. 559.

27 "World must deny legitimacy to Israel", Mail \& Guardian, 25 June-1 July 2010.

28 See Letter From The Editor, Dr Essop Pahad, pp. 2-3; Mats Svensson, "Sharpeville and the Ship to Gaza", The Thinker, Vol. 17, 2010, pp. 6-10. 



\section{The Politics of Paranoia: How - and Why - the European Radical Right Mobilizes Antisemitism, Xenophobia, and Counter-Cosmopolitanism}

\section{Lars Rensmann*}

\section{THE RADICAL RIGHT AND ANTISEMITISM: IRRELEVANT AT THE MARGINS?}

The radical right's anti-immigrant resentments, and especially its anti-Muslim campaigns, have come under public and scientific scrutiny in recent years (Mammone 2011). Yet antisemitism as an ideological factor in mobilizing radical right voters has neither been systematically examined in scholarly research, nor has it received much media attention -in spite of some heated scholarly meta-controversies about the "new antisemitism," that is, the partial or full convergence of radical right, radical left and Islamist antisemitism in the form of hatred of Israel and the chimera of "world Zionism." In fact, while there are some notable exceptions-studies that explore the radical right and antisemitism (e.g. Weitzman 2010; Rensmann 2011) - public and scholarly debates often a priori presuppose that antisemitism is an ideology that is past its expiration date and thus also without significance in the radical right's political and ideological mobilizations. Indeed, it is a widely shared belief in contemporary European publics that antisemitism has largely dissipated and generally become socially and politically irrelevant-even though such claims are difficult to substantiate and contradict social research findings. If antisemitism surfaces as a problem today, it is frequently suggested that it is instrumentalized and overused, presumably constituting an ubiquitous political charge allegedly employed by Jewish and Israeli lobbies in order to suppress dissent and fence off criticism of Israel in Europe and the United States (see, for instance, Mearsheimer \& Walt 2009; for a scholarly critique of these claims, see Lieberman 2009a; 2009b). In a similar vein, some scholars and political pundits have suggested that the European radical right, with its anti-Muslim vigor, has turned "pro-Israel" and "proJewish" (Bunzl 2007). Moreover, it has become popular to view Muslims as "the Jews of today," a trope insinuating that Muslims are the subject of forms of systematic persecution in Europe similar to those faced by Jews in European history and that Islamophobia has generally replaced - not just complemented - antisemitism in 21st century Europe,

* DAAD Assistant Professor of Political Science, University of Michigan at Ann Arbor. Some sections of this article are part of a broader study of this subject to be published in the Journal for the Study of Antisemitism. 
or, in other words, that Islamophobia has become the "new antisemitism" (Guarnieri 2010).

Looking at contemporary radical right ideology and its political context, this article challenges the aforementioned propositions. It claims that, while racialized hostility against Muslims plays an important role in many radical right mobilizations alongside general anti-immigrant resentment, antisemitism remains an integral - indeed in many cases reinforced-element of new radical right ideology. For much of the European radical right, antisemitism continues to function as a constitutive, prevalent conspiracy ideology to explain the modern world and its crises. New radical right parties tend to modernize their ideology in order to increase their appeal, although overtly racialized stereotypes of Jews, ethnic minorities, and immigrants - as well as Holocaust revisionism-continue to surface in political campaigns. For instance, the alleged powerful conspirators of world Jewry are today often called "world Zionists."

In general, the word "Zionists" is increasingly used as a synonym for "Jews" to make antisemitic attacks on world Jewry sound respectable. Among the radical right and beyond, the phrase the Zionists has generally become the main code for the Jews in antisemitic discourse. It blurs the boundaries between legitimate political critique, innuendo, and overt antisemitism, while mobilizing anti-Jewish resentments, and also helps avoid potential legal prosecution. In this ideological construct, the Jews and the Zionists seek to dominate the world, control Zionist-occupied governments (ZOGs) behind the scenes, and personify globalism and global modernity, including American and Zionist imperialism, the global financial system, and global capitalism.

Furthermore, the radical right's political antisemitism does not harm their political mobilizations but, on the contrary, feeds into an increased public legitimacy of hostility against Jews, which is fueled by perceptions of the Middle East conflict and widespread hatred of Israel in society, as well as the recent globalization crises. Such resentment marches in step with, and complements, anti-immigrant resentments and prejudices against ethnic minorities.

The following sections summarize the findings of several qualitative content analyses of radical right party manifestos and public campaigns in order to establish the constitutive features of the European radical right's contemporary ideology. It then examines the demand side, the general political context, and favorable conditions for radical right mobilizations of resentment, focusing in particular on the neglected resurgence of political antisemitism and its origins and causal mechanisms.

\section{ANTISEMITISM, XENOPHOBIA, AND COUNTER-COSMOPOLITANISM IN CONTEMPORARY RADICAL RIGHT PARTIES IN EUROPE: THE CASE OF HUNGARY}

In this section, I examine a country where the radical right has been most successful electorally: Hungary. The study focuses on the platforms and manifestos of the relevant radical right parties but also covers public statements by party leaders, party websites, and political campaigns as components shaping the political ideology of the European radical right. ${ }^{1}$ Special attention is paid to the modernization of radical right party ideology.

1 We classify parties as relevant that have shown at least some level of electoral success, scoring at least 3 percent or more in regional or national elections. 
MIÉP (Magyar Igazság és Élet Pártja-Hungarian Party for Justice and Life) has been the most successful radical right party in post-Communist Hungary in electoral terms but has faded in relevance in recent years. Under the authoritarian leadership of István Csurka, the party promotes exclusivist nationalism and expansionist ambitions, especially with regard to the Hungarian ethnic minority under foreign rule. ${ }^{2}$ The 2002 national electoral campaign focused on an interrelated set of anti-globalization, antisemitic, anti-Communist, and anti-Israel issues. Regarding any cooperation with the West as part of a US-Zionist plan, MIÉP continues to oppose EU membership and promotes a distinctly anti-Jewish, anti-globalization ideology. For instance, bankers are portrayed as a bunch of Jews sucking the money of average people. Viewing cosmopolitan Judeo-Bolshevik plutocrats and cosmopolitanism and globalization as the main enemy, the party has explained the electoral successes of the left and the alleged ongoing Communist rule in Hungary by referring to Jewish-Zionist activity (Stephen Roth Institute 2002). According to Csurka, Hungarians are being exploited and oppressed by Jews who dominate the economy and literature. He also fears a Jewish conspiracy, whose perpetrators are sitting in New York and Tel Aviv (cited in Bos 2011). Antisemitism and hatred of Israel are the core elements of this extreme ethno-nationalist party, while resentment against minorities (or Muslims) is also part of the party's ideology but less central to its identity.

However, the party has continuously lost ground since it won 5.5 percent of the vote in 1998. In 2004, electoral support for the MIÉP was down to 4.4 percent. By 2006, support for the party had fallen to 2.2 percent and it virtually dissolved, in spite of the fact that it had formed an electoral alliance with the initially even more radical Jobbik Magyarországért Mozgalom (Movement for a Better Hungary). Jobbik has since taken MIÉP's place as the most significant political and electoral extreme right force in Hungary. By 2008, the now independent Jobbik was already at 7 percent in national polls, and the party initially received a stunning 14.77 percent of the vote in the 2009 European elections. This turned Jobbik into the third strongest Hungarian party in the European Parliament. It consolidated this position in the Hungarian party system by mobilizing an average of 16.67 percent of the vote in the two rounds of the 2010 national elections.

Without being less radical in its ethnic nationalism, xenophobia, and, especially, antisemitism, Jobbik has managed to gain wider electoral appeal after its separation from MIÉP. Although the party's current chairman is the young historian Gábor Vona, the modern face of the party and its best-known and most popular politician is the human rights lawyer and law professor Krisztina Morvai. Morvai is the head of the party's EP delegation and has worked as a women's rights advocate at the United Nations but also has a strong record of anti-Israel advocacy. Her leadership role in this radical right, extremely nationalistic party took many by surprise and instantly helped Jobbik to gain broader legitimacy in spite of its radical platform and catering to militant fascists.

Jobbik's campaign platform for the 2010 elections declared the reunification of the Hungarian nation, the rebuilding of pre-1919 Greater Hungary, and (thus) the redrawing of Hungary's borders to be its first priority and most important political goal - a radical right, nationalist, and expansionist claim that could ultimately give rise to a war with its European neighbors. It shows very little political constraint and fosters a radical

2 See: <http://www.miep.hu>. 
political orientation and rhetoric that openly attacks gypsies and Jewish capital. Its propaganda, along with its use of certain political symbols, is clearly reminiscent of Nyilaskeresztes Párt (NYKP), Hungary's ruling Nazi party between 1944 and 1945, which established a ruthless terror regime that collaborated in the Holocaust (Maegerle 2009).

Its slightly more strategic mobilization focus is nostalgic Hungarian nationalism and opposition to globalism in its economic, political and cultural dimensions. Along with the leadership role of a feminist human rights lawyer, its fashionable opposition to globalism, the European Union, and foreign investment is turning the party into the prototype of a counter-cosmopolitan, modernized radical right party that seeks to mobilize both its core constituency of nationalist, radical right voters and a broader spectrum of globalization losers. While all the indicators of its counter-cosmopolitan ideological transformation are prevalent and highly salient, the party has not sacrificed its traditional fascist ideology and self-declared radicalism or its militancy, neither of which, incidentally, seem to alienate voters anyway. ${ }^{3}$ In 2007, Jobbik created the Magyar Gárda Kulturális Egyesület (Cultural Association of the Hungarian Guard). The Hungarian Guard is a paramilitary organization with sworn-in members designed "to awaken the active self-consciousness of the nation." In 2009, the organization was prohibited, and this ruling was later confirmed by the courts. Jobbik has not shied away from racist and antisemitic rhetoric. Party-affiliated publications employ inflammatory rhetoric against Jews, Roma, and homosexuals. Party members are linked to anti-Roma and antisemitic violence (Freeman 2009).

The party also proposes the creation of a special national police unit to deal with gypsy delinquency. While the party is open to militant Christian Hungarian nationalism and radicalism displayed by subgroups of the party and segments of the party elite, Jobbik has broadened its appeal and transformed its party ideology and identity. First and foremost, this includes a major focus on opposition to globalization and Europeanization. Reaching out to various disenfranchised segments of the Hungarian electorate, the modernized party platform is still dedicated to a combination of anti-globalization views and coded popular antisemitism, alongside its previous support of Christian values, Hungarian nationalism, and attacks on Roma and other ethnic minorities. Serving both radical nationalists and disillusioned voters, its economic policies are primarily directed against "the neoliberal ideology dominated policies during these years under the name of privatization, liberalization and deregulation," ${ }^{4}$ while it also rejects the Lisbon Treaty and European integration. Jobbik thus capitalizes on increasing joblessness, corruption crises, and social unrest caused by the global economic crisis. In light of widespread economic and cultural fears, the party mobilizes political and cultural resentments against pro-European and pro-cosmopolitan elites and minorities, as well as against multinational corporations, America, and Israel (i.e. globalism, imperialism, and international institutions).

The rise of Jobbik indicates that there is considerable legitimate political space for such counter-cosmopolitan, nationalistic, and antisemitic views in Hungarian politics. In fact, the party's success is accompanied by a broader right-wing, nationalistic trend in Hungarian politics. Challenging conventional wisdom about electorates and their spatial

3 See: <http://www.jobbik.com>.

4 Ibid. 
representation in the party system, there seems to be no trade-off between party constituencies supporting xenophobia and nationalistic claims. On the one hand, due to various factors - including major corruption cases - the left-of-center Magyar Szocialista Párt (MSZP), which was the major governing party for most of the post-Communist period, collapsed at the 2010 national elections, receiving only 19.3 percent of the vote. Severely weakened, MSZP is now barely the biggest opposition party. On the other hand, the national-populist Fidesz-Magyar Polgári Szövetség (Fidesz-Hungarian Civic Union) gained 52.73 percent of the vote in 2010. It thus achieved an absolute majority that equipped the party with a two-thirds majority in the national parliament and the power to make sweeping changes to the legal system.

The national-populist Fidesz, led since its inception by the populist prime minister Viktor Orbán, campaigns against anti-national elements. While Fidesz is less radical than Jobbik and combines various political constituencies in its policies, it also provides a government that is apparently sympathetic to radical nationalism and antisemitic resentment. For instance, without being penalized by the party, Fidesz member of parliament Oszkár Molnár stated: “I love Hungary, I love Hungarians, and I prefer Hungarian interests to global financial capital, or Jewish capital, if you like, which wants to devour the whole world, but especially Hungary." He also suggested that there was an Israeli conspiracy to colonize Hungary. Molnár found widespread support, even though the Fidesz government ratified an authoritarian media law that severely restricts freedom of speech on the pretense of fighting hate speech.

Hungary's restrictive media laws, poor civil rights record, and discriminatory policies have come under increasing scrutiny from the European Union. However, it is also a sign of the times and of the new assertiveness of the populist and radical right in Hungary and across Europe with regard to xenophobia and antisemitism that Jobbik can flourish and that even politicians of the ruling party can mobilize resentments against Jews and gypsies without facing effective political opposition. The Cultural Institute of the Republic of Hungary, operating under the auspices of the Fidesz government, initiates discussions about what it calls the Jewish problem and how to deal with it. It is even doing so in Germany, as part of transnational Hungarian cultural policy (Balassi Institute 2011).

Another sign of public collaboration with the radical right and the legitimacy of ethnic nationalism and antisemitism in Hungary is the fact that the mayor of Budapest, István Tarlós, recently appointed István Csurka, the leader of MIÉP, and the nationalist György Dörner as new directors of the Hungarian capital's prestigious New Theater, despite the concerns of Jewish groups and international condemnation. The new directors want to rename the theater and act against what they call "the degenerate sick liberal hegemony." They have demanded that only Hungarian drama be performed and want to stop what they refer to as "foreign garbage," which is regarded as a code word for Jewish and other non-Hungarian productions (Bos 2011).

\section{EUROPE'S RADICAL RIGHT AND THE MOBILIZATION OF RESENTMENT: COMPARATIVE FINDINGS}

If we look beyond Hungary, a comparative analysis of party ideologies and mobilizations in a study of 11 countries in Western and Eastern Europe reveals a partly heterogeneous picture. Political contexts and context-dependent variables play a significant 
role, and campaigns are rarely conducted transnationally. In part, they respond to specific national issues and electoral demands. However, even though ideological priorities and mobilizations vary, there are some prevalent ideological features that generally characterize the contemporary European radical right.

Firstly, all radical right parties share a high level of xenophobia and anti-immigrant resentment. Immigrants are blamed for all kinds of economic and social woes, as well as for the loss of cultural identity. At present, this resentment is often-though by no means exclusively - directed against Muslim immigrants and, depending on the country, specific ethnic minorities. This expresses an ethnic nationalism and collective selfunderstanding that remains a core feature of the European radical right. It is intimately related to opposition to cosmopolitan diversity. However, there are exceptions to the rule. In Eastern Europe, anti-Muslim prejudice plays only a marginal role, if any, in the public mobilization of the radical right. Jobbik, the most successful radical right party in Europe, is predominantly antisemitic and also discriminates against Roma. In contrast, Muslims are largely irrelevant in campaigns.

Secondly, while retaining an ethnic-nationalist ideological profile, several relevant European radical right parties, have also become partly transnational in outlook. They claim to defend a Europe of nations against cosmopolitan influences and immigration, multi-national corporations, and global political norms and institutions, including EU governance. Some parties have developed a highly modernized, radically countercosmopolitan, anti-globalization identity (Mudde 2007) that reflects widespread sentiments in the electorate. The "counter-cosmopolitan" defense of cultural particularism includes, but is not limited to, national particularism.

Thirdly, and closely related to the second feature, antisemitism remains a core element of radical right ideology, old and new. In several cases, there is even a noticeable resurgence of antisemitism, at times coded in radical anti-Israel resentments, denouncements of "world Zionism" or "foreign influence," and conspiracy theories. ${ }^{5}$ Such antisemitic mobilizations are often directly linked to the anti-globalization discourse, in which Jews are identified as the key agents of cosmopolitan cultural change, global power, and the global financial and economic system. Once again, Jews serve as a personified, reified explanation for the world's ills. To be sure, the demonstrable relevance and revival of antisemitism in radical right ideology is at odds with popular perceptions of the radical right. Moreover, some premature scholarly claims that antisemitism has virtually disappeared as a mobilizing resource for the new radical right due to its allegedly bygone appeal run counter to our findings.

Rather, we are witnessing the emergence of a new ideology that combines domestic resentment against Muslims with hatred of Jews and opposition to cosmopolitan norms and cosmopolitanization processes. In several cases, Israel, world Zionism, and Israel lobbies have become the primary target in the radical right's approach to foreign affairs, which fosters support for radical Islamist terror against Jews and Israel, even though Muslim immigrants are not accepted as equal members of society.

\footnotetext{
5 This should not be misunderstood as any kind of lexical ordering.
} 


\section{THE RESURGENCE OF COUNTER-COSMOPOLITANISM, XENOPHOBIA, AND ANTISEMITISM IN EUROPE}

Before exploring several hypotheses to explain why such an ideological combination, and the resurgence of antisemitism in particular, may be an effective mobilizing tool in party systems in contemporary Europe, this section takes a close look at the changing political climate and the increased popular demand for counter-cosmopolitan, xenophobic, and antisemitic politics. This demand finds expression in (i) widespread, increasing resentments against Jews, Muslims, and immigrants; and (ii) the increased public and political salience of these subjects and related issues. In addition, (iii) economic and socio-cultural globalization crises tend to embolden and intensify previously existing antisemitic undercurrents, including reified perceptions of globalization and the cosmopolitanization of societies as "Jewish machinations."

\section{A. Increasing resentment of Jews and Muslims}

PEW data indicate a strong relationship between anti-Jewish and anti-Muslim sentiments. Indeed, in the six European countries included in the PEW survey, the correlation between unfavorable opinions of Jews and unfavorable opinions of Muslims is remarkably high (neg .80; PEW 2008). Overall, negative views of Muslims have increased over in recent years. Exceptions are Spain and Germany, where negative views of Muslims are nevertheless still high (52 percent and 50 percent respectively). Moreover, there has been considerable progress in the cosmopolitanization of European societies (i.e. the diversification of European societies and the recognition of cosmopolitan diversity and norms). Yet there is still a considerable segment of the electorate that is hostile to immigrants and the socio-cultural change they represent. Largely overlooked in public debates, antisemitism has surged and resurged in Europe since the turn of the century. Antisemitism is a far cry from being merely an historical legacy. Instead, empirical data show that antisemitic attitudes remain an undercurrent-even if varying in scope and intensity - within European societies. Not only that: surveys indicate that such resentments are now more prevalent than in previous decades and that they matter more to certain segments of voters. Antisemitism, like xenophobia, is no marginal minority opinion at the fringe of society.

On average, antisemitic attitudes have been on the rise in Europe since 2000, although there are fluctuations and considerable cross-national variations. Moreover, hatred of Israel and "Zionists" has become a medium to express hatred of Jews. Forms of radical anti-Zionism, wishing for the destruction of the Jewish state and the deZionization of the world, may also be motivated by secondary antisemitism (Rensmann 1998): the desire to morally demonize Jews because they are living reminders of the German and European atrocities committed against them during the Nazi era. Equating the Zionists with Nazis is a way to project guilt and settle an old score. According to a seven-country survey including the most populous EU member states, almost every second European (45.7 percent) uses Nazi associations and comparisons when thinking of Israel. This means that they somewhat or strongly agree that "Israel is conducting a war of extermination against the Palestinians," while 37.4 percent agree with the statement that "considering Israel's policy I can understand why people do not like Jews" (Zick 2009: 13). 


\section{B. Increased public and political salience}

Antisemitism and hostility against Muslims have become more salient issues in public, political, and media spheres. Anti-Muslim hostility seems to benefit from media debates about mosques and the alleged introduction of Sharia law. In recent years, the political and public discourse in Europe is also characterized by a high level of awareness and alertness in the face of anti-Muslim campaigns or statements. For instance, a popular bestselling book by former German politician Thilo Sarrazin, which includes blatantly xenophobic, racialized anti-Muslim claims, was subjected to scathing criticism by the German public and its political class. After the terrorist acts of Anders Behring Breivik in Norway in 2011, the public debate about anti-Muslim hostility reached a new peak, and anti-Muslim radical right groups such as Stop the Islamisation of Norway (SIAN) have come under renewed public scrutiny. Anti-Muslim resentments are becoming increasingly unacceptable to European publics, and parties associated with anti-immigrant or anti-Muslim resentments have recently lost electoral support. For instance, the national populist Progress Party of Norway suffered significant losses in local elections in the aftermath of Breivik's terror acts.

However, while the public focus has shifted to anti-Muslim prejudices, which remain a controversial issue from which the radical right might still draw long-term gains, radical right parties also benefit from an increasingly legitimate public discourse that is hostile to Jews. This aspect has been neglected in recent research. There is an expanding zone of acquiescence in relation to antisemitism, which also finds reflection in the radical right, that has so far hardly been recognized in research on the subject. This increased legitimacy, or public tolerance, of anti-Jewish resentment is characterized by shifting boundaries in what is considered respectable discourse about Jews and Zionists. It also finds expression in the rise of conspiracy theories, which often lead directly to a reservoir of antisemitic images of Jews allegedly pulling the strings and controlling the world. Furthermore, antisemitism is also nurtured by a popular Manichean world view that is not necessarily antisemitic in itself but helps create a climate of anti-Jewish hostility and is increasingly gaining traction in European publics. It portrays the two countries in which most of the world's Jews live, namely the United States and Israel, as the main - if not the onlyvillains in world politics and the global economy, while letting brutal dictatorships and repressive regimes across the world off the hook. Anti-Israel sentiments and anti-Zionism that go far beyond criticism of the Israeli government and its policies are in most cases no longer discredited as illegitimate resentments against another group or country but have become a badge of honor even among public figures and politicians on the left, who otherwise tend to support anti-discrimination policies and universal human rights (Hirsh 2007; Markovits 2011; Rensmann \& Schoeps 2011; Wistrich 2010).

In its radical version, this Manichean world view manifests itself in publicly articulated stereotypes about war-mongering Zionists and a globally powerful Israel lobby that dominates governments and stifles free debate about Israel's atrocities against innocent Palestinians. Such claims go hand in hand with a widespread immunization strategy in the form of antisemitism denial that reaches deep into the public and the political left. According to this view, antisemitism today is a priori relevant only insofar as it is seen as a spurious charge that the Zionists or the pro-Israel lobby would throw at critics of Israel (Hirsh 2007: 73). Flanked by the claim that criticism of Israel cannot be antisemitic (cited in Hirsh 2007) and the belief that, if there is any antisemitism, Israel is 
to blame for its emergence, highly emotionalized boycott campaigns directed exclusively against the Jewish state are taking place across Europe. They are emboldened by the widely popular charge that Israel is an apartheid regime that deserves to be dismantled. Singling out Israel as a pariah among the nations, the aggressive demonization of the Jewish state far beyond any rational criticism, and the simultaneous denial of the problem of antisemitism are not limited to the radical right. They resonate in segments of the public across the political spectrum as well as in civil society, including left-wing student and teacher unions and the media. More often than not, such aggressive antiZionism slips into overt antisemitic stereotypes and resentment. For instance, the leftleaning British newspaper The Guardian recently published an article in which journalist Deborah Orr claimed that the Israel-Hamas prisoner swap-Hamas released the captured soldier Gilad Shalit in exchange for the release of 1,000 Palestinians responsible for the death of 600 Israelis, most of the victims women and children - proved that Israel nurtures a supremacist Jewish self-understanding of being a "chosen" people whose lives are worth a thousand times the lives of others (Orr 2011).

There is, at any rate, a noticeable erosion of the discursive boundaries that evolved in postwar Europe-about what is tolerated as part of public discourse and what is classified or scandalized as hate speech - with regard to Jews and Zionists. The most recent indicator of antisemitism's renewed public toleration, if not legitimacy, is the fact that the extreme nationalist, radical right LAOS party, along with its chairman Georgios Karatzaferis, is part of the new Greek coalition government that was established in response to the European debt crisis. The LAOS party, claiming to represent true Greeks instead of Jews, homosexuals and Communists, campaigns against Jews and Israel in particular. The party received 7 percent of the vote in the last national election. Karatzaferis is a self-professed Holocaust denier who hates Israel and is known for his openly antisemitic statements. After the 9/11 attacks in New York, he repeated the myth that all the Jews were warned not to come to work that day before the Greek parliament. He has also questioned historical accounts of Auschwitz and Dachau. During Israel's Operation Cast Lead in 2008, Karatzaferis said that the Israel Defense Forces were acting "with savage brutality only seen in Hitler's time towards helpless people" (Uni 2011).

\section{Impact of global economic and socio-cultural crises}

Finally, global crises and crises relating to globalization have provided a fertile climate for the mobilization of resentments against immigrants and Jews on the grounds that they are responsible for these problems. By personifying the origins of theses crises in immigrants, foreign capital, and the Jews, in particular, the radical right can tap intoand strengthen the link between - existing social resentments and current multi-faceted crises of global modernity. In particular, the identification of Jews with globalism and cosmopolitan political, economic, and socio-cultural transformations corresponds to what we call counter-cosmopolitanism, that is, the generalized, particularistic opposition to the combined set of political, cultural, and economic transformations associated with globalization and cosmopolitan value change (Rensmann 2011; Rensmann \& Miller 2010; Markovits \& Rensmann 2010). ${ }^{6}$

6 This rejection is part and parcel of, but not limited to, nationalistic attitudes; it can also entail religiously or culturally grounded motivations, and it can be expressed transnationally in its own organizational outreach or political alliance-building. 
Counter-cosmopolitanism - the unqualified rejection of all forms of socio-cultural, economic, and political globalization, as well as cosmopolitan norms and diversity - is likely to become more prevalent during global crises. Counter-cosmopolitan parties, which generally oppose globalization and the cosmopolitanization of society (Beck \& Grande 2007), seek to strategically mobilize those citizens who identify with the national community, citizens from economic strata that have traditionally been protected by the nation state and now find themselves increasingly exposed to foreign competition, and those who lack the cultural competence to meet the economic and cultural challenge of a globalizing world (Kriesi et al. 2008).

While counter-cosmopolitanism bolsters hostility against immigrants and cultural change, it particularly encourages hostility against Jews. As a form of reified critique of globalization, such generalized counter-cosmopolitanism is highly susceptible to conspiracy theories that invoke the old social image of the cosmopolitan wandering Jew. In antisemitic narratives, Jews have traditionally been identified with modernity, cosmopolitanism, and globalism. Jews or Zionists are now often charged with cosmopolitan social change, global wars and global domination, cultural diffusion, the global erosion of the nation state, "dual loyalties," and capitalist crises. It is, after all, one of modern antisemitism's distinct feature to function as an objectified explanation of the modern world. In this ideology, Jews are seen as the embodiment of these cultural and economic modernizations processes (including immigration) and as the agents that orchestrate them. In a world of abstract domination governed by complex, abstract, and anonymous social relations, the antisemites disclose the world's problems as a Zionist scheme. The widespread uneasiness that is felt in the changing, postmodern world is thus projected onto the image of the Jew. If this projection is not framed as a global Jewish conspiracy, the problems in question are often blamed squarely on the Zionists and the allegedly disproportionate Jewish influence on politics and the media at national and global level through the powerful, secret Israel lobby and the Holocaust industry.

\section{CONCLUSION}

There is continuity and change in the political ideology of the radical right parties in Europe. A focus on anti-immigration issues and anti-Muslim resentment is accompanied by virulent antisemitism. Contrary to common perceptions, the latter remains an integral part of the radical right's political identity and mobilization. While anti-Muslim resentments often matter, the claim that antisemitism has been "replaced" by other resentments cannot be substantiated; it is equally untrue that the European radical right has largely turned "pro-Israel" (Bunzl 2007). Instead, most of the radical right prominently features modernized, "anti-globalist," and "anti-Zionist" antisemitism. Crossnational variations notwithstanding, antisemitism has gained in importance. This is especially true for the most successful radical right parties in Eastern and Western Europe, such as Jobbik (Hungary), LAOS (Greece), and FPÖ (Austria). In many instances, radical right parties cater to broader counter-cosmopolitan constituencies. This emerging modernized ideological profile combines xenophobic resentment against immigrants and European Muslims with a counter-cosmopolitan agenda, domestic antisemitism, and modernized anti-Zionist antisemitism in foreign affairs. Even though Muslim immigrants are rejected domestically, radical Islamists still gain the sympathy of the radical right for their struggle against world Zionism. 
These mobilizations and transformations on the radical right supply side are supported by a set of favorable conditions. Radical right parties articulate an evident electoral demand by catering to significant counter-cosmopolitan constituencies that harbor resentments against social and cultural change in general and immigrants and Jews in particular. Moreover, they benefit from a broader European political climate in which certain anti-immigrant resentments have resurfaced and in which forms of modernized antisemitism (Rensmann \& Schoeps 2011) are becoming increasingly respectable and tolerated. Finally, the radical right is one of several agents that seeks to exploit current European and globalization crises affecting European citizens, such as the European financial debt crisis, and feeds into persisting anti-Jewish undercurrents and conspiracy theories. These crises can also be seen as crises of cosmopolitanism that help foster counter-cosmopolitan responses, including hostility against immigrants and Jews.

The radical right's resurgent and reloaded politics of paranoia in Europe find a special target in Jews and Zionists. The new and modernized radical right, emulating the old, thus plays its part in the emergence of a new international antisemitism. The oftneglected, and at times denied, revival of antisemitism in radical right party ideology and beyond epitomizes what could happen, both on the political demand side and on the political supply side, in the event of a deeper political crisis in Europe. The broader resurgence of antisemitism can be theorized as an anti-modern, counter-cosmopolitan response to rapid economic and cultural change and current crises in the 21st century. Part and parcel of, but far from limited to, the radical right, there are indicators that this reaction has begun to move from the fringes to the center.

\section{REFERENCES}

Appiah, Kwame Anthony (2007) Cosmopolitanism (New York: W.W. Norton).

Arzheimer, Kai (2009) "Contextual Factors and the Extreme Right Vote in Western Europe, 1980-2002." American Journal of Political Science 53(2): 259-275.

Balassi Institute (2011) Programm des Kulturinstituts der Republik Ungarn, available at: <http://www.collegium-hungaricum.at/index2.jsp?HomeID=14\&lang=GER\&std_ func $=P R G \& i d=41497 \&$ high_art=true\&page=2> (retrieved November 7, 2011).

Beck, Ulrich \& Edgar Grande (2007) Cosmopolitan Europe (Cambridge: Polity Press).

Bernáth, Gábor, Gábor Miklósi \& Cas Mudde (2005) “Hungary.” In: Cas Mudde (ed.) Racist Extremism in Central and Eastern Europe (London: Routledge): 80-100.

Betz, Hans-Georg (2002) "Conditions Favoring the Success and Failure of Radical RightWing Populist Parties in Contemporary Democracies." In: Yves Mény \& Yves Surel (eds.) Democracies and the Populist Challenge (New York: Palgrave): 197-213.

Bos, Stefan J. (2011) “Theater row deepens concern over Hungary's burgeoning nationalism." Deutsche Welle World, October 25, 2011, available at: <http://www.dw-world.de/ $\mathrm{dw} /$ article/0,,15484656,00.html $>$ (retrieved November 12, 2011).

Bunzl, Matti (2007) "Anti-Semitism and Islamophobia." In: Matti Bunzl (ed.) AntiSemitism and Islamophobia: Hatreds Old and New in Europe (Chicago: Prickly Paradigm Press): 1-46. 
Cesarani, David (2008) Are Muslims the New Jews? Comparing Islamophobia and AntiSemitism in Britain and Europe, available at: <http://www.isgap.org/david-cesarani> (retrieved November 14, 2011).

Enyedi, Zsolt (2008) "The Social and Attitudinal Basis of Political Parties: Cleavage Politics Revisited." European Review 16(3): 287-304.

Golder, Matt (2003) "Explaining Variation in the Success of Extreme Right Parties in Western Europe." Comparative Political Studies 36(4): 432-466.

Guarnieri, Mya (2010) “Islamophobia: The New Antisemitism.” The Guardian, August 26, 2010.

Hainsworth, Paul (2008) The Extreme Right in Western Europe (New York: Routledge).

Held, David \& Anthony McGrew (2002) Globalization/Antiglobalization (Cambridge: Polity Press).

Hirsh, David (2007) Anti-Zionism and Antisemitism: Cosmopolitan Reflections (New Haven: Yale Initiative for the Interdisciplinary Study of Antisemitism Working Papers).

Hix, Simon \& Christopher Lord (1997) Political Parties in the European Union (New York: St. Martin's Press).

Hockenos, Paul (2010) “Inside Hungary's Anti-Semitic Right-wing." Global Post, June 1, 2010, available at: <http://www.globalpost.com/dispatch/europe/100528/hungaryjobbik-far-right-party> (retrieved November 12, 2011).

Ignazi, Piero (2003) Extreme Right Parties in Western Europe (Oxford: Oxford University Press).

Inglehart, Ronald \& Christian Welzel (2005) Modernization, Cultural Change, and Democracy (Cambridge: Cambridge University Press).

Ishiyama, John T. (2004) “Does Globalization Breed Ethnic Conflict?" Nationalism and Ethnic Conflicts 9: 1-23.

Ivanov, Christo \& Margarita Ilieva (2005) “Bulgaria." In: Cas Mudde (ed.) Racist Extremism in Central and Eastern Europe (London: Routledge): 1-30.

Jungerstam-Mulders, Susanne (2006) "Party System Change in Post-Communist EU Member States." In: Susanne Jungerstam-Mulders (ed.) Post-Communist EU Member States: Parties and Party Systems (London: Ashgate, 2006): 233-256.

Kaldor, Mary (1997) “Cosmopolitanism versus Nationalism: The New Divide?” In: R. Caplan \& J. Feffer (eds.) Europe's New Nationalism (Oxford: Oxford University Press): 42-58.

Kriesi, Hanspeter (1999) "Movements of the Left, Movements of the Right: Putting the Mobilization of Two New Types of Social Movements into Political Context." In: H. Kitschelt (ed.) Continuity and Change in Contemporary Capitalism (Cambridge: Cambridge University Press): 398-423.

Kriesi, Hanspeter, Edgare Grande, Martin Dolezal et al. (2006) "Globalization and the Transformation of the National Political Space: Six European Countries Compared." European Journal of Political Research 45: 921-956.

Lieberman, Robert C. (2009a) “The 'Israel Lobby' and American Politics." Perspectives on Politics 7(2): 235-258.

Lieberman, Robert C. (2009b) "Rejoinder to Mearsheimer and Walt." Perspectives on Politics 7(2): 275-283.

Maegerle, Anton (2009) Rechts am Rand in Osteuropa. Ein Überblick über osteuropäische Rechtsaußenparteien. Bundeszentrale für politische Bildung, June 3, 2009, available at: $<$ http://www.bpbp.de> (retrieved June 15, 2010). 
Mair, Peter (1997) Party System Change: Approaches and Interpretations (Oxford: Clarendon).

Mair, Peter (2007) "Political Opposition and the European Union." Government and Opposition 42(1): 1-17.

Mammone, Andrea (2011) "The Future of Europe's Radical Right: Why the Politics of Race are Here to Stay." Foreign Affairs, September 20, 2011.

Markovits, Andrei S. (2011) "Antisemitism and Anti-Americanism: Comparative European Perspectives." In: Lars Rensmann \& Julius H. Schoeps (eds.) Politics and Resentment: Counter-Cosmopolitanism and Antisemitism in the European Union (Boston \& Leiden: Brill): 147-182.

Markovits, Andrei S. \& Lars Rensmann (2010) Gaming the World: How Sports Are Reshaping Global Politics and Society (Princeton: Princeton University Press).

Mearsheimer, John J. \& Stephen Walt (2009) "The Blind Man and the Elephant in the Room: Robert C. Lieberman and the Israel Lobby." Perspectives on Politics 7(2): 259274.

Meguid, B.M. (2008) Party Competition Between Unequals: Strategies and Electoral Fortunes in Western Europe (Cambridge: Cambridge University Press).

Mudde, Cas (2007) Populist Radical Right Parties in Europe (Cambridge: Cambridge University Press).

Norris, Pippa (2005) Radical Right: Voters and Parties in the Electoral Market (New York: Cambridge University Press).

Orr, Deborah (2011) "Is an Israeli life really more important than a Palestinian's?" The Guardian, October 19, 2011, available at: <http://www.guardian.co.uk/world/2011/ oct/19/israeli-lives-more-important-palestinian> (retrieved November 5, 2011).

PEW Global Attitudes Project (2008) Unfavourable Views of Jews and Muslims on the increase in Europe (Washington, D.C.: PEW), available at: <http://pewglobal.org/reports/ pdf/262.pdf $>$.

Rensmann, Lars (2011) “Against 'Globalism': Antisemitism and Counter-Cosmopolitanism in the Party Ideology of the Radical Right in Europe." In: Lars Rensmann \& Julius H. Schoeps (eds.) Politics and Resentment: Counter-Cosmopolitanism and Antisemitism in the European Union (Leiden \& Boston: Brill): 117-146.

Rensmann, Lars \& Jennifer Miller (2010) “Xenophobia and Anti-Immigrant Politics.” In: Robert A. Denemark (ed.) International Studies Encyclopedia: Ethnic Minorities and Migration (Oxford: Blackwell): 7628-7653.

Rensmann, Lars \& Julius H. Schoeps (2011) "Politics and Resentment: Examining Antisemitism and Counter-Cosmopolitanism in the European Union and Beyond." In: Lars Rensmann \& Julius H. Schoeps (eds.) Politics and Resentment: Antisemitism and Counter-Cosmopolitanism in the European Union (Leiden \& Boston: Brill): 3-79.

Rydgren, Jens (2005) "Is Extreme Right Populism Contagious? Explaining the Emergence of a New Party Family." European Journal of Political Research 44(3): 413-437.

Sartori, Giovanni (1976) Parties and Party Systems (Cambridge: Cambridge University). Stricker, Sarah (2009) “Europe: Antisemitism Up, Islamophobia Down.” Muslim Media Network, available at: <http://muslimmedianetwork.com/mmn/?tag=university-ofbielefeld >; <http://www.antisemitism.org.il/eng/events/44847/Europe\%E2\%80\%93 Study:antisemitismup,Islamophobiadown> (retrieved November 12, 2011).

Uni, Assaf (2011) “'Holocaust Denier' Set for Key Role in Greek Government?” Ynet News, November 11, 2011, available at: <http://www.ynetnews.com/articles/0,7340,L4146898,00.html> (retrieved November 11, 2011). 
Weitzman, Mark (2010) Magical Logic: Globalization, Conspiracy Theory, and the Shoah, available at: <http://sicsa.huji.ac.il/weitzman.pdf>.

Zick, Andreas et al. (2009) European Conditions. Findings of a Study on Group-focused Enmity in Europe (Berlin: Amadeu Antonio Stiftung/Universität Bielefeld). 


\title{
Penalizing Holocaust Denial: A View from Europe
}

\begin{abstract}
Aleksandra Gliszczyńska-Grabias*
The visual evidence and the verbal testimony of starvation, cruelty and bestiality were so overpowering as to leave me a bit sick. In one room, where [there] were piled up twenty or thirty naked men, killed by starvation, George Patton would not even enter. He said that he would get sick if he did so. I made the visit deliberately, in order to be in a position to give first-hand evidence of these things if ever, in the future, there develops a tendency to charge these allegations merely to "propaganda."
\end{abstract}

General Dwight D. Eisenhower ${ }^{1}$

The alleged Hitlerian gas chambers and the alleged genocide of the Jews form one and the same historical lie, which permitted a gigantic financial swindle whose chief beneficiaries have been the State of Israel and international Zionism, and whose main victims have been the German people and the Palestinian people as a whole.

Robert Faurisson ${ }^{2}$

\section{INTRODUCTION}

Incorporating Holocaust denial into the catalogue of issues governed by legal provisions, and in particular by the provisions of criminal law, raises a number of understandable doubts. Aside from the controversies related to the indisputable interference with freedom of speech, there are problems concerning the form of legal provisions that would ban the dissemination of the negationists' theories, as well as difficulties in guaranteeing the effectiveness and consistency of their proper enforcement. ${ }^{3}$

* Research Assistant, Poznań Human Rights Centre, Institute of Legal Studies of the Polish Academy of Sciences; Graduate Fellow, Yale Initiative for the Interdisciplinary Study of Antisemitism (YIISA), Yale University.

1 Dwight D. Eisenhower, Dear General: Eisenhower's Wartime Letters To Marshall (1999), p. 223.

2 Robert Faurisson, as quoted by the Guardian Weekly, Apr. 7, 1991.

3 The term negationism in relation to Holocaust denial seems to be more appropriate than the frequently applied term revisionism. The school of revisionism may be associated with historical research, whereas Holocaust denial has nothing in common with any academic conduct. Negationism comprises multiple forms of denying historical truth. Most frequently however, it is used to describe various forms of Holocaust denial. See, e.g., Deborah Lipstadt, Denying the Holocaust: The Growing Assault on Truth and Memory (1994); Michael Shermer and Alex Grobman, Denying History: Who Says the Holocaust Never Happened and Why Do They Say It? (2000). 
In the United States, the essential differences between the European and the American understanding of the free speech doctrine lead to distrust of and even objections to every single court trial or a custodial sentence for a Holocaust denier in Europe. ${ }^{4}$ Moreover, the question whether - and if so how - to punish someone for Holocaust denial, but also more broadly for hate speech dissemination, poses a challenge, especially for those European enthusiasts of the greatest possible freedom of speech. This is because they simultaneously and (apparently) contradictorily acknowledge the need to resort to legal instruments that restrict this freedom, in order to protect different values and the rights of other individuals.

The US "First Amendment ethos" makes it almost impossible to accept the restrictive way of dealing with negationists that we see in so many European legal orders. ${ }^{5}$ Conversely, most Europeans find the US legal doctrine of the unlimited freedom of speech, including Holocaust denial, disturbing. One of the primary reasons for such a discrepancy in legal attitudes is the estimated risk of the danger that negationists are likely to cause. As Professor Wojciech Sadurski puts it:

In the United States, the groups which feed on the literature such as "historical revisionism" are part of the political folklore, just as are flat-Earthers and Montana separatists: probably irritating and deeply offensive to many, but very unlikely to reach a capacity to challenge the democratic system to its core. ${ }^{6}$

However, there are numerous other complex and persuasive factors that are crucial to the establishment of a legal ban on Holocaust denial in Europe. This article introduces the most fundamental arguments raised in the European discourse in favor of penalizing Holocaust denial.

\section{HOLOCAUST DENIAL - DEFINITIONAL CONTROVERSIES}

The basic difficulty that occurs while discussing the idea of penalizing Holocaust denial concerns the attempt to define the concept in legal terms. Due to the lack of a coherent, internationally recognized definition of the crime of negationism as a whole and Holocaust denial in particular, the scope of the penalization may differ considerably. ${ }^{7}$ At the

4 The differences between the European and American perceptions of the conflict between free speech and hate speech cover many more issues than only Holocaust denial. A compelling description of the American understanding of the civil liberties doctrine in the context of hate speech can be found in a book by Aryeh Neier, former leader of the American Civil Liberties Union. See Aryeh Neier, Taking Liberties. Four Decades in the Struggle for Rights (2003), pp. 113-33.

5 The European states that penalize Holocaust denial are: Austria, Belgium, Czech Republic, France, Germany, Lichtenstein, Lithuania, Luxembourg, the Netherlands, Poland, Portugal, Romania, Slovakia, and Switzerland. After the entry into force of EU Council Framework Decision 2008/913/JHA of 28 November 2008 on combating certain forms and expressions of racism and xenophobia by means of criminal law, all EU member states are legally obliged to penalize certain forms of negationism.

6 Wojciech Sadurski, "'It All Depends': The Universal and the Contingent in Human Rights," European University Institute Working Paper LAW No. 2002/7 (2002), p. 28.

7 The UN General Assembly has stated that it condemns without any reservation any denial of the Holocaust. See G.A. Res. 61/251, UN Doc. A/RES/61/255, Mar. 22, 2007. See also Jonathan Cooper and Adrian Marshall Williams, Hate Speech, Holocaust Denial and International Human Rights Law, 6 European Human Rights Law Review (1999), p. 593. 
same time, such divergence in definitions allows for a more flexible approach, in which the newly generated forms of Holocaust denial can also be considered as legally forbidden negationism.

\section{A. Domestic law in European states}

We observe different approaches to negationism in the legal provisions of European states that penalize the public dissemination of Holocaust denial. It speaks for itself that historical factors play a major role in defining the crime of negationism, as well as the political intention to shape and influence the memory of the nation.

Under Polish law, it is legally forbidden to deny, publicly and contrary to the facts, Nazi crimes, communist crimes, and other crimes constituting crimes against peace, crimes against humanity, or war crimes perpetrated against persons of Polish nationality and Polish citizens of other ethnicity or nationality in the period between September 1, 1939 and July 31, 1990. Such denial is subject to a fine or a custodial penalty of up to three years, and the judgment is to be made public. ${ }^{8}$ The objective scope of the provision is not limited to negationism concerning crimes committed by Nazi Germany; it also covers denial of the Katyn massacre. ${ }^{9}$

The French Gayssot Act, named after its initiator, Jean-Claude Gayssot (a socialist deputy in the French parliament), imposes a punishment of one month to one year of imprisonment or a fine for individuals who publicly question the existence of one or more crimes against humanity. These are crimes that have been defined in the statute of the International Military Tribunal at Nuremberg, included in the London Agreement of 8 August 1945 and carried out either by members of an organization declared criminal pursuant to Article 9 of the aforementioned statute or by a person found guilty of such crimes under French or international jurisdiction. ${ }^{10}$

German law regulates the issue of penalizing Holocaust denial in a more complex way. There are several provisions that may be invoked against Holocaust deniers. One of the provisions allows for penalizing anyone who publicly approves of, denies, or belittles an act committed under the rule of National Socialism in a manner capable of disturbing the public peace. Such a person shall be punished with imprisonment of up to five years or a fine. ${ }^{11}$

The Austrian solution for penalizing Holocaust denial was introduced in 1992 in the form of an amendment to the Prohibition Act of 1947, a special bill that banned the Nazi Party and provided the legal framework for the process of removing all possible consequences of Nazism from Austria. It was designed to suppress any potential future revival of the murderous Nazi regime. ${ }^{12}$ However, the foremost reason for introducing the legal ban on Holocaust denial in Austria was a number of court proceedings in

8 Polish Official Journal, No. 155, Item 1016, Dec. 18, 1998, available at: <http://isap.sejm.gov.pl>.

9 In the spring of 1940, the Soviets murdered almost 20,000 Polish prisoners of war-military officers, policemen, and intellectuals - in the forest of Katyn.

10 French Official Journal, No. 162, July 13, 1990, available at: <http://www.legifrance.gouv.fr/ affichTexte.do?cidTexte=LEGITEXT000006076185\&dateTexte=vig $>$. html $>$.

11 German Official Journal, Nov. 13, 1998, available at: <http://bundesrecht.juris.de/stgb/_130.

12 Austrian Official Journal, No. 148/1992, Mar. 19, 1992, available at: <http://www.nachkriegs justiz.at/service/gesetze/BGBl_148_1992.gif>. 
which Holocaust deniers were acquitted due to an ineffective basis for accusation. Austrian judges regarded the legal ban on incitement to racial hatred as inapplicable to the negation of the Holocaust. ${ }^{13}$ As a result, a new provision was introduced. It stipulates that whoever denies, grossly plays down, approves of, or tries to excuse the National Socialist genocide or other National Socialist crimes against humanity in a printed publication, in a broadcast, or in any other media shall be punished with imprisonment for one to ten years and, in cases of particularly dangerous suspects or activity, up to twenty years. The court may also decide in favor of the forfeiture of property, which usually relates to the entire print run of the publication containing the negationists' theories.

Liechtenstein ${ }^{14}$ and Romania ${ }^{15}$ explicitly mention the Holocaust in their negationism penalization laws. Liechtenstein law penalizes anyone who through speech, pictures, writing, or electronic media denies, crudely deprecates, or tries to justify the Holocaust or other crimes against humanity with imprisonment for up to two years. Romanian law, on the other hand, punishes public negation of the Holocaust or its effects with imprisonment for six months to five years. It is also prohibited to erect or maintain in a public space statues, statuary groups, or commemorative plaques celebrating persons guilty of committing crimes against peace or humanity, or to name streets, boulevards, squares, parks, or other public spaces after such persons. ${ }^{16}$

If one agrees that penalizing this form of negationism is legitimate and relevant, it should be stated that, in order to make the penal method effective, the legal definition of Holocaust denial must be sufficiently broad and encompass not only the negation of the Holocaust but also, inter alia, its trivialization and justification. However, accepting such an extensive definition obviously implies a higher risk of excessive interference in the sphere of free speech and freedom of scientific research. It is also bound up with doubts concerning the legal interpretation of such legally imprecise concepts as trivialization or justification. Nevertheless, the Europeans remain firmly convinced that the interpretative difficulties do not prevail over the need to legally regulate the dissemination of Holocaust denial. This is because the boundary between legal and illegal behavior in this area is very fine, making it highly inadvisable to leave such behavior without clarification and an appropriate legal response.

\section{B. The Council of Europe}

The creation of the Council of Europe is inextricably linked to the horrors of World War II and the Holocaust. Accordingly, all member states of the Council of Europe unanimously recognize any manifestation of antisemitism as a human rights violation and regard the obligation to fight it as an integral part of counteracting racism in Europe.

13 See Stephen J. Roth, Denial of the Holocaust. An Issue of Law (1994), pp. 221-22.

14 Lichtenstein's Official Journal, Article 283, June 24, 1987, available at: <http://www.gesetze.li/ Seite1.jsp?LGBlm=1988037>.

15 Emergency Ordinance 31/2002 of the Penal Code, Monitorul official al Romaniei, Mar. 28, 2003, cited in Final Report of the International Commission on the Holocaust in Romania, presented to President Ion Iliescu, Bucharest, Nov. 11, 2004, p. 36.

16 See databases of the EU Fundamental Rights Agency, available at: $<$ http://fra.europa.eu/fra Website/products/products_en.htm>. 
This position of the Council of Europe has been confirmed repeatedly. ${ }^{17}$ The need to engage in an active and effective fight against antisemitism, together with the willingness to do so, was also one of the motivations behind the establishment of the Council of Europe's European Commission against Racism and Intolerance (ECRI), which occurred during the First Vienna Summit Conference of Heads of State and Government of the member states of the Council of Europe in 1993. ${ }^{18}$ In the "Vienna Declaration" adopted at that time, a common policy for counteracting racism, xenophobia, antisemitism, and intolerance was agreed upon. In this declaration, the member states of the Council of Europe declared that they would combat all ideologies, policies, and practices constituting incitement of racial hatred, violence, and discrimination, as well as any action or language likely to strengthen fears and tensions between groups of different racial, ethnic, national, religious, or social background.

In 1997, the executive body of the Committee of Ministers of the Council of Europe issued a recommendation that deals exclusively with the phenomenon of hate speech. ${ }^{19}$ In the appendix to that recommendation, hate speech was defined as speech covering all forms of expression that spread, incite, promote, or justify racial hatred, xenophobia, antisemitism, or other forms of hatred based on intolerance, including: intolerance expressed by aggressive nationalism and ethnocentrism, and discrimination and hostility against minorities, migrants and people of immigrant origin. It is important that the concept of Holocaust denial was included in the category of speech that disseminates and propagates antisemitism.

In light of the growing wave of antisemitic attitudes in the member states of the Council of Europe, the Parliamentary Assembly of the Council of Europe adopted Resolution No. 1563, entitled "Combating anti-Semitism in Europe." ${ }^{20}$ The Assembly emphasized the immense danger of antisemitism and called on all member states of the Council of Europe to vigorously and systematically enforce legislation criminalizing antisemitic and other hate speech, in particular any incitement to violence. In addition, it called on all member states to make public denial, as well as trivialization, justification, or praise, with racist intentions, of crimes of genocide, crimes against humanity, or war crimes, a criminal offense. The resolution also includes a call to actively and strongly condemn all states sponsoring antisemitism, Holocaust denial, and incitement to genocide.

17 See, e.g., Council of Europe Parliamentary Assembly Recommendations: No. 1222 (1993) on the fight against racism, xenophobia and intolerance; No. 1275 (1995) on the fight against racism, xenophobia, anti-Semitism and intolerance; No. 1438 (2000) on the threat posed to democracy by extremist parties and movements in Europe; and No. 1543 (2001) on racism and xenophobia in cyberspace. See also Council of Europe Parliamentary Assembly Resolutions: No. 1308 (2002) on restrictions on political parties in the Council of Europe member states; and No. 1345 (2003) on racist, xenophobic and intolerant discourse in politics. All available at: <http://assembly.coe.int/ ASP/Doc/ATListing_E.asp>.

18 The compilation of the Council of Europe documents, available at: <http://www.coe.int/t/dcr/ summit/decl_vienne_pl.asp>.

19 Council of Europe Committee of Ministers Recommendation No. R (97) 20 on hate speech, available at: $<\mathrm{https} / /$ wcd.coe.int/com.instranet.InstraServlet?command=com.instranet.CmdBlobGet \&InstranetImage $=568168 \&$ SecMode $=1 \&$ DocId $=582600 \&$ Usage $=2>$.

20 Council of Europe Parliamentary Assembly Resolution No. 1563 (2007) on combating antiSemitism in Europe, available at: $<$ http://assembly.coe.int/main.asp?Link=/documents/adoptedtext/ ta07/eres1563.htm>. 
Moreover, the Additional Protocol to the Council of Europe Convention on Cybercrime, concerning the criminalisation of acts of a racist and xenophobic nature committed through computer systems, deals with the issue of Holocaust denial in its Article 6, which stipulates that the each state party to the protocol:

shall adopt such legislative measures as may be necessary to establish the following conduct as criminal offences under its domestic law, when committed intentionally and without right: distributing or otherwise making available, through a computer system to the public, material which denies, grossly minimizes, approves or justifies acts constituting genocide or crimes against humanity.... ${ }^{21}$

A direct reference to the need to penalize Holocaust denial may also be found in ECRI General Policy Recommendation No. 9: "The fight against anti-Semitism." 22 The most important aspect of the this recommendation concerns the form of legal provisions in the Council of Europe member states and their effective implementation. States should ensure that for all criminal offenses, antisemitic motivation will be regarded as an aggravating circumstance. The ECRI mentions the following actions, which, if committed intentionally, should be penalized: the public denial, trivialization, justification, or condoning of the Holocaust and the public denial, trivialization, justification, or condoning, with an antisemitic aim, of crimes of genocide, crimes against humanity, or war crimes committed against persons on the grounds of their Jewish identity or origin. Moreover, the ECRI recommendation indicates the need to punish by legal means the public dissemination or public distribution, or the production or storage aimed at public dissemination or public distribution, of antisemitic written, pictorial, or other material containing, inter alia, Holocaust denial. ${ }^{23}$ The need to implement an effective legal ban on disseminating Holocaust denial is thus emphasized here in the most explicit way.

\section{European Union}

The record of the debates, which took place over many years, on the shape of the common Council Framework Decision 2008/913/JHA of 28 November 2008 on combating certain forms and expressions of racism and xenophobia by means of criminal law indicate that those who supported the introduction of an obligation to penalize Holocaust denial by the EU member states followed the European rationale for such penalization. ${ }^{24}$ It should be emphasized that these provisions were the object of serious and turbulent disagreement, which obviously stemmed from the different approaches of individual EU member states to the general problem of penalizing speech.

Article $1(1)(d)$ of the Framework Decision obliges the EU member states to take the necessary measures to ensure that the following intentional conduct is punishable:

21 Additional Protocol to the Convention on Cybercrime, concerning the criminalisation of acts of a racist and xenophobic nature committed through computer systems, available at: <http:// conventions.coe.int/Treaty/en/Treaties/Html/189.htm>. The Additional Protocol entered into force on March 1, 2006 and has been by now ratified by 19 European states.

22 ECRI General Policy Recommendation No. 9 on the fight against anti-Semitism, CRI (2004) 37, available at: <http://www.legislationline.org/documents/action/popup/id/7388>.

23 Id.

24 Council of the European Union Framework Decision 2008/913/JHA of 28 November 2008 on combating certain forms and expressions of racism and xenophobia by means of criminal law, $\mathrm{OJ} \mathrm{L}$ 328/55, Dec. 6, 2008. 
publicly condoning, denying or grossly trivialising the crimes defined in Article 6 of the Charter of the International Military Tribunal appended to the London Agreement of 8 August $1945,{ }^{25}$ directed against a group of persons or a member of such a group defined by reference to race, colour, religion, descent or national or ethnic origin when the conduct is carried out in a manner likely to incite to violence or hatred against such a group or a member of such a group.

Article 1 also introduces a similar ban with respect to genocide, crimes against humanity, and war crimes as defined by the Statute of the International Crime Court. ${ }^{26}$ Not-

25 Article 6 of the Charter of the International Military Tribunal-Annex to the Agreement for the prosecution and punishment of the major war criminals of the European Axis ("London Agreement") stipulates:

The Tribunal established by the Agreement referred to in article 1 hereof for the trial and punishment of the major war criminals of the European Axis countries shall have the power to try and punish persons who, acting in the interests of the European Axis countries, whether as individuals or as members of organizations, committed any of the following crimes.

The following acts, or any of them, are crimes coming within the jurisdiction of the Tribunal for which there shall be individual responsibility:

(a) Crimes against peace: namely, planning, preparation, initiation or waging of a war of aggression, or a war in violation of international treaties, agreements or assurances, or participation in a common plan or conspiracy for the accomplishment of any of the foregoing;

(b) War crimes: namely, violations of the laws or customs of war. Such violations shall include, but not be limited to, murder, ill-treatment or deportation to Wave labour or for any other purpose of civilian population of or in occupied territory, murder or ill-treatment of prisoners of war or persons on the seas, killing of hostages, plunder of public or private property, wanton destruction of cities, towns or villages, or devastation not justified by military necessity;

(c) Crimes against humanity: namely, murder, extermination, enslavement, deportation, and other inhumane acts committed against any civilian population, before or during the war, or persecutions on political, racial or religious grounds in execution of or in connection with any crime within the jurisdiction of the Tribunal, whether or not in violation of the domestic law of the country where perpetrated.

Leaders, organizers, instigators and accomplices participating in the formulation or execution of a common plan or conspiracy to commit any of the foregoing crimes are responsible for all acts performed by any persons in execution of such plan.

See Appendix II of The Charter and Judgment of the Nürnberg Tribunal: History and Analysis, United Nations General Assembly/International Law Commission, New York, 1949, Doc. A/CN.4/5, available at: <http://www.unhcr.org/cgi-bin/texis/vtx/refworld/rwmain>.

26 Article 6 of the Rome Statute of the International Criminal Court defines the crime of genocide as:

... any of the following acts committed with intent to destroy, in whole or in part, a national, ethnical, racial or religious group, as such:

(a) Killing members of the group;

(b) Causing serious bodily or mental harm to members of the group;

(c) Deliberately inflicting on the group conditions of life calculated to bring about its physical destruction in whole or in part;

(d) Imposing measures intended to prevent births within the group;

(e) Forcibly transferring children of the group to another group.

See Rome Statute of the International Criminal Court, Doc. A/CONF.183/9, available at: <http:// www.icc-cpi.int/Menus/ICC/Legal+Texts+and+Tools>. 
withstanding these provisions, the final content of the Framework Decision was disappointing to its supporters. ${ }^{27}$ Rapporteur Martine Roure of the EU Committee on Civil Liberties, Justice, and Home Affairs stated in her report on the proposal for a Council Framework Decision, she "regrets the failure of the Council's text to move strongly forward and rise to the political challenge posed by the fight against racism and xenophobia." She vociferously opposed the limits placed on the scope of the Framework Decision concerning the penalization of negationism in domestic law, according to which member states are free to chose to punish only such behavior that is likely to incite to violence or hatred. Martine Roure rightly claimed that: "Trivialisation of the crime of genocide is a form of racism, and Member States should be able to punish it even where incitement to hatred or violence is not involved."

The Framework Decision indeed makes it possible to significantly limit the obligations imposed on member states. In addition to the remarks quoted above, member states may also declare that denying or grossly trivializing the crimes listed in the Framework Decision shall be penalized only if these crimes have been established by a final decision of a national court of a particular member state and/or an international court or by final decision of an international court only. ${ }^{28}$

The Framework Decision came into force in December 2008, but the substance of the decision required a prolonged period of transposition in the EU member states. ${ }^{29}$ The states were obliged to take the necessary measures to comply with the provisions of this Framework Decision by November 28, 2010. By the same date, they were required to transmit to the General Secretariat of the Council and to the Commission the text of the provisions transposing the Framework Decision into their domestic legal orders. By November 28, 2013, the Council will assess the extent to which member states have complied with the provisions of the Framework Decision and review the Framework Decision. It seems highly likely that those member states that had not penalized any form of negationism before the entry into force of the Framework Decision will find it very difficult to comply with this part of the Decision. It remains an open question whether, or to what extent, the 2013 review process will indicate the need to exclude the ban on negationism from the scope of the Framework Decision.

It was claimed, in light of the significant differences in the legislation of the EU member states in the areas covered by the framework decision, as well as their different political and social traditions, that the compromise achieved was the only possible solution at this stage of the negotiations. However, although the Framework Decision contains several important and necessary elements, the document as a whole appears to be rather limited in scope. Nevertheless, the efforts to harmonize legislation at the EU level and the establishment of a consolidated catalogue of sanctions to be imposed against hate crimes and hate speech (including the public dissemination of negationism) is an important step in combating all forms of racism and intolerance.

27 See, e.g., Report on the proposal for a Council framework decision on combating certain forms and expressions of racism and xenophobia by means of criminal law, Nov. 14, 2007, presented by Martine Roure MEP. The description of the entire tumultuous negotiation process related to the adoption of the Framework Decision is available at: <http://ec.europa.eu/prelex/detail_ dossier_real.cfm?CL=en\&DosId=169885>.

28 Article 1(4) of the Framework Decision.

29 Article 10 of the Framework Decision. 


\section{FUNDAMENTAL PREREQUISITES FOR HOLOCAUST DENIAL PENALIZATION IN EUROPE}

As discussed above, the issue of Holocaust denial and its penalization is of a profound significance for Europe. In order to carefully identify the reasons that justify restricting the freedom of speech of Holocaust deniers, it is essential to explain the essence of this phenomenon beyond its legal definition.

In layman's terms, Holocaust denial is a form of negationism that refers mainly to the act of denying, trivializing, or justifying the crimes committed by Nazi Germany against the Jews during World War II, although it should be clear that denying these crimes affects all victims and not only the Jewish ones. In practice, however, Holocaust denial is carried out almost exclusively in relation to Jews, and this is how it is being popularized throughout the world. Professor Wojciech Sadurski rightly describes this phenomenon as "a part of a larger package of an ideology which maintains that Jews cannot be trusted on anything, even on their own past." 30

In 1984, during a seminar held at the Hebrew University of Jerusalem, Professor Yisrael Gutman posed the question whether Holocaust denial was simply a short-lived phenomenon, or whether it had a future and would have to be dealt with. ${ }^{31}$ Today, when the theories spread by negationists have supporters all around the world, and the president of Iran openly claims that Holocaust is a fiction made up by Jews, raising Holocaust denial to the rank of a state doctrine, the answer to Professor Gutman's question is, unfortunately, straightforward.

The circle that has gathered around the idea of Holocaust denial has always consisted of people from many different milieus, representing a wide spectrum of personal backgrounds and political ideals, even though the representatives of the post-war neoNazi movement in Germany, France, and the United Kingdom initially prevailed. ${ }^{32}$ Currently, the circle of Holocaust deniers around the world is much wider and has strengthened enormously, also in a financial sense, due to the support it obtains from many Arab states. ${ }^{33}$

As time has passed, the range of statements described as Holocaust denial has also changed. The opinion of researchers dealing with the issue was initially that Holocaust denial was meant to clear the blame for the ideas of National Socialism and Hitler. ${ }^{34}$ Since then, the claims of Holocaust deniers have become more nuanced. They argue, inter alia, that even if Holocaust really took place, the number of victims was signifi-

30 Sadurski, supra note 6, p. 27.

31 See Yisrael Gutman, Denying the Holocaust (1985), pp. 20-25.

32 See, e.g., Shermer and Grobman, supra note 3; Walter Laqueur, The Changing Face of AntiSemitism: From Ancient Times to the Present Day (2006), pp. 135-39.

33 The most well-known examples are nowadays the statements of Iranian President Mahmoud Ahmadinejad, who repeatedly claims that the Holocaust was nothing but a "Jewish swindle." For coverage, see, e.g., Anne Appelbaum, "Teheran's Holocaust Lesson," The Washington Post online, Dec. 12, 2006, available at: <http://www.washingtonpost.com/wp-dyn/content/article/2006/12/11/AR 2006121101163.html>.

34 Deborah E. Lipstadt calls this kind of Holocaust denial hard core Holocaust denial, distinguishing it from soft core Holocaust denial, which includes, for example, describing military interventions of the Israeli army as the "Palestinian Holocaust." See Deborah E. Lipstadt's blog at: $<$ http://lipstadt.blogspot.com>. 
cantly lower than what the official statistics indicate; that it is true that many Jews perished during the war, but most of them were victims of contagious diseases and hard living conditions; that Hitler had never signed any written order to murder the whole Jewish population in Europe, so the Holocaust could not be described as a complex, precise plan; that Auschwitz was not a concentration camp but only a labor camp, equipped with such facilities as a swimming pool or a dance hall; that Zyklon B was only used for disinfection purposes; that gas chambers were first built after the war; that the testimonies of the former prisoners of the camps are not veracious, as they were given only to gain undue financial benefits; and that the evidence given by the former camp guards and Nazis was elicited by means of torture.

The threat stemming from the dissemination of Holocaust denial becomes even more apparent when one considers that general knowledge about World War II and the Holocaust in Europe. The level of historical awareness in society has always been the best guarantor of preserving historical memory. However, as indicated by a poll conducted in Great Britain in 2004, over 60 percent of the British population under the age of 35 have not heard of the "Final Solution," and 30 percent of students surveyed in high schools in Brussels in 2005 were convinced that Oskar Schindler was one of Hitler's advisers. It is thus clear how much opportunity has arisen for those who wish to distort and misrepresent historical truth. ${ }^{35}$ It should also be emphasized that, in the age of the Internet, the possibilities for disseminating negationist theories are almost limitless. This is proven by thousands of websites that furnish information about the "great Jewish lie" in a way that makes them appear to be based on reliable, scientifically-proven facts. ${ }^{36}$

It is clear that the low level knowledge in society about the Holocaust and the lack of an appropriate response to its negation or trivialization are not in themselves a sufficient justification for penalizing Holocaust denial. Also, penalization should not stem solely from the fact that the claims of negationists are outrageous and evoke moral objections. If so, what are the reasons for recognizing the legitimacy of punishing words in the case of Holocaust denial? The most fundamental grounds for such legitimacy, identified in the European discourse, are the following:

- the necessity to turn the memory and honor of the victims of the Holocaust into a legally protected value;

- the conviction that restricting the negationists' freedom of speech is acceptable in order to protect the very fundamental element of the history and national identity of certain European states and the heritage of European civilization as a whole; and

- the recognition of Holocaust denial as one of the modern forms of antisemitism and a form of hate speech directed at Jews that may lead not only to a rise in antisemitic moods and attitudes but also to a rise in hate crimes committed on this basis.

35 The data cited are sourced from a survey commissioned by the BBC in December 2004 and from an opinion poll conducted by Res Publica, a Belgian political quarterly, in January 2005. Quoted from the Znak website, available at: $<$ http://www.forumznak.org.pl/?lang1=pl\&page1=news \&subpage1=news00\&infopassid1 $=2432 \&$ scrt1=sn $>$ (in Polish).

36 The significance of the problem of the dissemination of hate speech and Holocaust denial via the internet was explicitly acknowledged in the above-mentioned Additional Protocol to the Convention on Cybercrime, concerning the criminalization of acts of a racist and xenophobic nature committed through computer systems. 
Such universal and axiological reasons (which are to be distinguished from the formal prerequisites that must be fulfilled in order to use a specific legal provision limiting the freedom of speech of the individual) should be seen as an attempt to formulate a justification for introducing a legal ban on disseminating Holocaust denial, in the sense that they indicate the European legislators' rationale for using penal sanctions against negationists.

\section{A. Memory and honor of the victims}

The memory and honor of the victims has been strongly emphasized in Germany, where the dissemination of Holocaust denial is punishable on the basis of regulations that prohibit insulting and humiliating the dead, among other legal methods. ${ }^{37}$ However, this approach to penalization carries with it the risk of the negative effects of trials involving Holocaust deniers, which often turn into bizarre shows during which negationists get a chance to present their theories to a wider audience. This, in turn, may be perceived as an additional insult to the memory of the dead.

However, the consequence of trying to avoid such situations would be that no person who is willing to defend the legitimacy of his or her actions in court would be punished, on the grounds that it might encourage others to take similar actions or insult the feelings of individuals who suffered as victims of such actions. Moreover, the public spectacle of David Irving, the notorious Holocaust denier, denouncing his theories in front of an Austrian judge and loudly admitting that the Holocaust was indeed a crime perpetrated by Nazi Germany and that gas chambers were indeed used to kill the Jewish people ridicules the whole negationist movement and illustrates the weakness of this ideology. Thus, the existing negative aspects of the judicial consideration of Holocaust deniers' guilt should not be seen as a sufficient argument against punishing Holocaust denial by means of legal instruments.

\section{B. Historical truth and identity}

The essence of the second reason for penalizing Holocaust denial, which is related to the preservation of historical heritage, is well captured in the words of Marek Safjan, a Polish judge of the European Court of Justice in Luxembourg. In the context of the discussion on the penalization of Holocaust denial in Poland, Professor Safjan has noted: "Human memory is short and deceptive, while the trivialization of lies and hatred disseminated in public space may have shocking and destructive effects, particularly for the young generation of Europeans." ${ }^{38}$ In other words, punishing negationists is also aimed at halting the process of the gradual fading of the memory of the Holocaust and the crimes of totalitarian regimes, which are still not yet a thing of the past.

This argument also emphasizes the educational role of the state, which by introducing a legally protected taboo affirms certain values, such as a commitment to nondiscrimination on the grounds of national, racial, or ethnic grounds. However, this

37 German Official Journal, Nov. 13, 1998, available at: <http://bundesrecht.juris.de/stgb/_189. html>.

38 Marek Safjan, Wolność słowa w debacie europejskiej, Otwarta Rzeczpospolita Stowarzyszenie przeciwko Antysemityzmowi i Ksenofobii, available at: <http://www.otwarta.org/marek-safjanwolnosc-slowa-w-debacie-europejskiej, $400 . \mathrm{html}>$ (in Polish). 
approach also carries a certain risk, namely that regulations that are only of a symbolic character will not be strictly executed. As a result of their controversial nature or vague wording, such provisions can thus be a risky method of assuring justice. Yet in the case of Holocaust denial, the significance of such provisions is deemed to prevail over any doubts. Moreover, from a European perspective, a proper legal response is an explicit form of warning against totalitarian regimes, which are always capable of resurgence.

\section{Hate speech and hate crime}

With regard to the third reason for penalizing Holocaust denial, which concerns the correlation between hate speech and hate crimes, it is important to remember that while most statements denying the Holocaust do not contain openly hostile or hateful antisemitic messages, the antisemitic motives for disseminating such statements are obvious to anybody who analyzes them in a broader context. For example, denying the Holocaust has been described as a manifestation of antisemitism in ECRI Recommendation No. 9 and in the working definition of antisemitism prepared by the European Monitoring Center on Racism and Xenophobia (which became the European Union Agency for Fundamental Rights in 2007), as well as in resolutions of the European Parliament. ${ }^{39}$

Therefore, if we assume that Holocaust denial is a form or at least a manifestation of antisemitism, the legal regulations that would ban its dissemination must be regarded as part of a broader state strategy that aims to fight all forms of racial, national, or religious hatred and intolerance. The European states have undertaken international obligations in this respect, also in the legal sphere, by becoming parties to a number of international human rights treaties. ${ }^{40}$

39 See, e.g., European Parliament resolution on remembrance of the Holocaust, anti-Semitism and racism, P6_TA (2005) 0018, available at: $<$ http://www.europarl.europa.eu/sides/getDoc.do?type $=$ TA\&reference=P6-TA-2005-0018\&language $=\mathrm{EN}>$.

40 See, e.g., Article 4 of the International Convention on the Elimination of All Forms of Racial Discrimination, which stipulates that:

States Parties condemn all propaganda and all organizations which are based on ideas or theories of superiority of one race or group of persons of one colour or ethnic origin, or which attempt to justify or promote racial hatred and discrimination in any form, and undertake to adopt immediate and positive measures designed to eradicate all incitement to, or acts of, such discrimination and, to this end, with due regard to the principles embodied in the Universal Declaration of Human Rights and the rights expressly set forth in article 5 of this Convention, inter alia:

(a) Shall declare an offence punishable by law all dissemination of ideas based on racial superiority or hatred, incitement to racial discrimination, as well as all acts of violence or incitement to such acts against any race or group of persons of another colour or ethnic origin, and also the provision of any assistance to racist activities, including the financing thereof;

(b) Shall declare illegal and prohibit organizations, and also organized and all other propaganda activities, which promote and incite racial discrimination, and shall recognize participation in such organizations or activities as an offence punishable by law;

(c) Shall not permit public authorities or public institutions, national or local, to promote or incite racial discrimination.

International Convention on the Elimination of All Forms of Racial Discrimination, adopted and opened for signature and ratification by General Assembly resolution 2106 (XX), available at: $<$ http://www2.ohchr.org/english/law/cerd.htm\#4>. 
It is possible that Holocaust denial does not translate into sudden, intense explosions of antisemitic sentiment or lead directly to acts of violence against Jews. However, a strong correlation between words and actions is indisputable, although it is difficult to determine when the critical transition takes place. Various forms of antagonism may lie dormant for long periods of time only to suddenly escalate, reaching the proportions of a mass psychosis. The history of the Third Reich's hate propaganda leaves no room for doubt regarding the influence that words may have on deeds.

One recent, dramatic example of this correlation is the radio broadcasts aired on a Rwandan radio stations at the time of the genocide. Due to high rates of illiteracy in Rwanda, radio served as a powerful and effective way of inciting hate and violence against the inyenzi (cockroaches), a derogatory term used to describe the Tutsis. ${ }^{41}$ One of the key figures engaged in using words as a tool of genocide was Georges Ruggiu, a Belgian journalist who was found guilty of public incitement to commit genocide and crimes against humanity by the International Criminal Tribunal for Rwanda. ${ }^{42}$ As the Tribunal stated in its judgment:

The media, particularly RTLM radio, was a key tool used by extremists within the political parties to mobilize and incite the population to commit the massacres. RTLM had a large audience in Rwanda and became an effective propaganda instrument. The accused, who was a journalist and broadcaster with the RTLM, played a crucial role in the incitement of ethnic hatred and violence, which RTLM vigorously pursued.... His broadcasts incited massacres of the Tutsi population. ${ }^{43}$

In this context, attention should also be drawn to the annual reports of the European Union Agency for Fundamental Rights and the Council of Europe's European Commission Against Racism and Intolerance, which point not only to an apparent increase in racist, xenophobic, and antisemitic attitudes in most European countries but also to the growing number of assaults, beatings, and other acts of violence committed on the same grounds. ${ }^{44}$

\section{IV.THE EUROPEAN COURT OF HUMAN RIGHTS}

The essence of each of the above-mentioned reasons for penalizing Holocaust denial is clearly mirrored in the case law of the Strasbourg-based European Court of Human Rights (ECtHR), the supervisory body of the European system of human rights protec-

41 Report by the International Development Research Centre, "Hate media in Rwanda," available at: <http://www.idrc.ca/rwandagenocide/ev-108178-201-1-DO_TOPIC.html>.

42 The Prosecutor v. Georges Ruggiu, Judgment and Sentence, ICTR-97-32-I, International Criminal Tribunal for Rwanda, June 1, 2000.

43 Id.

44 See, e.g., the following reports of the Fundamental Rights Agency: "Anti-Semitism: Summary overview of the situation in the European Union 2001-2009"; "Anti-Semitism: Summary overview of the situation in the European Union 2001-2008 (updated version February 2009)"; "Annual report 2007: Report on Racism and Xenophobia in the Member States of the EU"; and "Racist Violence in 15 EU Member States Based on RAXEN information," all available at: <http:// www.fra.europa.eu/fraWebsite/research/research_en.htm>. See also the reports of the European Commission against Racism and Intolerance in which it examines the situation concerning manifestations of racism and intolerance in each of the Council of Europe member states, all available at: $<$ http://www.coe.int/t/dghl/monitoring/ecri/activities/countrybycountry_en.asp>. 
tion. ${ }^{45}$ The Court (and previously also the European Commission of Human Rights, which served as a part of the Strasbourg system until 1998) has repeatedly been faced with the problem of evaluating the methods by which the member states of the Council of Europe limit the freedom of speech of Holocaust deniers by means of their domestic legislation. It is significant that up until now the ECtHR has consistently and unambiguously refused to grant protection to Holocaust deniers, ruling that their complaints concerning the limitation of free speech were inadmissible. ${ }^{46}$

However, the ECtHR's position in regard to Holocaust denial has never been based on one consistent way of reasoning. The Strasbourg Court has used various techniques to establish the inadmissibility of negationists' attempts to defend their views under Article 10 (freedom of speech) of the European Convention on Human Rights. ${ }^{47}$ In several cases, it has ruled that the legal limitations imposed on Holocaust deniers' free speech by the member states were necessary for the protection of the rights of others, the public security, or public morals in a democratic society. At other times, the ECtHR has invoked Article 17 of the Convention, which stipulates that: "Nothing in this Convention may be interpreted as implying for any State, group or person any right to engage in any activity or perform any act aimed at the destruction of any of the rights and freedoms set forth herein...." As a result, every attempt by negationists to rely on Article 10 is regarded as an abuse of the rights guaranteed in this international human rights treaty.

45 The European Court of Human Rights is an international court set up in 1959. It rules on individual or state applications alleging violations of the civil and political rights set out in the European Convention on Human Rights. Since 1998 it has sat as a full-time court and individuals can apply to it directly. The Court's case law makes the Convention a powerful living instrument for meeting new challenges and consolidating the rule of law and democracy in Europe. On the case law of the Strasbourg Court regarding hate speech and Holocaust denial, see, e.g., Uladzislau Belavusau, "A Dernier Cri from Strasbourg: An Ever Formidable Challenge of Hate Speech," European Public Law, Vol. 16(3) (2010), pp. 373-89; Ivan Hare, "Extreme Speech under International and Regional Human Rights Standards," in Ivan Hare and James Weinstein (eds.), Extreme Speech and Democracy (2009); M.G. Schmidt and R.L. Vojtovic, "Holocaust Denial and Freedom of Expression," in T.S. Orlin and M. Scheinin, The Jurisprudence of the Human Rights Law: A Comparative Interpretive Approach (2000).

46 Complaints by Holocaust deniers were found inadmissible in numerous cases, including: $T$. v. Belgium, App. No. 9777/82 (1983); F.P. v. Germany, App. No. 19459/92 (1993); Honsik v. Austria, App. No. 25062/94 (1995); Remer v. Germany, App. No. 25096/94 (1995). Nachtmann v. Austria, App. No. 36773/97 (1998); and Witzsch v. Germany, App. No. 41448/98 (1999).

47 Article 10 of the European Convention of Human Rights stipulates:

1. Everyone has the right to freedom of expression. This right shall include freedom to hold opinions and to receive and impart information and ideas without interference by public authority and regardless of frontiers. This article shall not prevent States from requiring the licensing of broadcasting, television or cinema enterprises.

2. The exercise of these freedoms, since it carries with it duties and responsibilities, may be subject to such formalities, conditions, restrictions or penalties as are prescribed by law and are necessary in a democratic society, in the interests of national security, territorial integrity or public safety, for the prevention of disorder or crime, for the protection of health or morals, for the protection of the reputation or rights of others, for preventing the disclosure of information received in confidence, or for maintaining the authority and impartiality of the judiciary.

Convention for the Protection of Human Rights and Fundamental Freedoms, CETS No. 5, available at: $<$ http://conventions.coe.int/treaty/Commun/QueVoulezVous.asp?NT=005\&CL=ENG $>$. 
X. v. Germany is one of the earliest cases concerning Holocaust denial that were examined by the Strasbourg Court. ${ }^{48}$ The author of the complaint had displayed pamphlets that described the Holocaust as an "unacceptable lie" and a "Zionist swindle" on a notice board located on the fence of his property. A neighbor of Jewish descent whose grandfather had been murdered in Auschwitz filed a civil lawsuit against him. The Court of First Instance ruled that despite the fact that the pamphlets did not directly address the neighbor or his grandfather, they must be considered offensive to all Jewish victims of National Socialism and their surviving relatives. The court instructed Mr. X. to refrain from expressing his beliefs publicly. However, the Court of Appeal ruled that contents of the pamphlets, which denied the facts of the Holocaust, did not insult people of Jewish origin as a whole but only individuals who expressed certain opinions on the extermination of Jews during the Third Reich, opinions which, according to Mr. X., were untrue. The Federal Court of Justice issued a decision reiterating its previous rulings on this issue, according to which in Germany, because of its history, every individual of Jewish descent may feel insulted by attacks on Jews as a group or as a community, regardless of his or her personal experiences during the time of the Nazi regime, and even regardless of whether the person was alive at the time. The Court emphasized that Holocaust denial is not covered by the freedom of speech enshrined in the German Constitution.

The complaint filed by Mr. X. before the Strasbourg Court referred specifically to an alleged violation of Article 10 (freedom of speech) of the Convention, which in his opinion had taken place as a result of the distortion of historical truth by the German nation for political reasons. He also claimed a violation of Article 6 (right to a fair trial) of the Convention, due to the German court's refusal to order a review of popular Holocaust denial publications and views, which were supposed to serve as evidence in the civil suit.

Concerning the alleged violation of Article 10, the European Commission of Human Rights (which at that time decided on the admissibility of applications) delivered a very significant judgment, finding that:

it was neither arbitrary nor unreasonable to consider the pamphlets displayed by the applicant as a defamatory attack against the Jewish community and against each individual member of this community. By describing the historical fact of the assassination of millions of Jews, a fact which was even admitted by the applicant himself, as a lie and a Zionistic swindle, the pamphlets in question not only gave a distorted picture of the relevant historical facts but also contained an attack on the reputation of all those who were described as liars or swindlers, or at least as persons profiting from or interested in such lies or swindles. The Commission considers that the courts rightly identified this as the underlying tendency of the pamphlets in question. Their restriction was therefore not only covered by a legitimate purpose recognised by the Convention (namely the protection of the reputation of others), but could also be considered as necessary in a democratic society. Such a society rests on the principles of tolerance and broadmindedness which the pamphlets in question clearly failed to observe. The protection of these principles may be especially indicated vis-à-vis groups which have historically suffered from discrimination. The fact that collective protec-

48 X. v. Federal Republic of Germany, App. No. 9235/81 (1982). 
tion against defamation is limited to certain specific groups including Jews is based on objective considerations and does not involve any element of, discrimination contrary to Article 14 of the Convention.

Furthermore, in response to the accusation that, by not admitting the negationist materials as evidence, the German courts had violated Article 6 of the Convention, the Commission reiterated that the crime of the Holocaust was a historical fact that was proven beyond any reasonable doubt and did not need to be proven in the courtroom again. The German courts were not required to rule on whether or not the contents of the pamphlets were true but to consider the question concerning their insulting nature. In conclusion, the European Commission stated that the entire complaint of Mr. X. was manifestly ill-founded.

The Strasbourg Court also considered the penalization of Holocaust denial in another interesting context. This complaint concerned the imposition by the authorities of the city of Munich of various duties on the far-right National Democratic Party of Germany (NDP) relating to the organization of a conference, entitled "Germany's future in the shade of political extortion?," where David Irving, a well-known antisemite and Holocaust denier, was to deliver a key lecture. ${ }^{49}$ The NDP was obliged to ensure that the crime of the Holocaust would not be denied during the course of the entire conference and to inform participants of the sanctions resulting from incitement to hatred and insulting the memory of the dead. If statements denying the Holocaust were made, the organizers of the conference were obliged to block them or even to discontinue the conference immediately. Because of David Irving's participation in the conference, the risk that statements negating the Holocaust would be made during the course of the conference was regarded as very high. The NDP's complaint regarding the decision of the Munich authorities was rejected in subsequent court proceedings. Ultimately, the German Federal Constitutional Court ruled yet again that Holocaust denial did not fall under the constitutional protection of freedom of speech.

The authors of the application submitted to the Strasbourg Court claimed in particular that:

statements denying the persecution of Jews under the Nazi regime, in particular the denial of the existence of gas chambers were protected by the Convention as statements or opinions relating to contemporary history. In this respect, the applicant organisation maintains that, according to scientific research, the gas chambers in Auschwitz were not authentic.

In the NDP's opinion, the scheduled conference was only meant to discuss the concept of anti-German atrocity propaganda.

The European Commission of Human Rights held that the application was clearly inadmissible and that the intervention of the German authorities had been justified and proportionate. According to the Commission, David Irving's presence had rightly been regarded as a factor that made it highly probable that statements denying the Holocaust would be made and that public order disturbances would occur. The German authorities had been thus right to take steps to prevent this from happening. Referring to Article 17

49 Nationaldemokratische Partei Deutschlands, Bezirksverband Muenchen-Oberbayern v. Germany, App. No. 25992/94 (1995). 
of the Convention, the Commission ruled that statements negating the persecution of millions of Jews by the Nationalist Socialist regime made in the context of a discussion about "anti-German atrocity propaganda," were contrary to the essential values underlying the entire Convention.

Among the numerous complaints submitted to the ECtHR by Holocaust deniers is the one of Roger Garaudy, one of the key leaders of the European negationist movement, who had been fined by the French courts for denying the Holocaust. ${ }^{50}$ In the process of considering the legitimacy of said complaint, the Court unambiguously articulated its standpoint regarding attempts to use the Convention by persons who disseminate Holocaust denial. In its decision, the Court firmly asserted that Holocaust denial is:

one of the most serious forms of racial defamation of Jews and of incitement to hatred of them. The denial or rewriting of this type of historical fact undermines the values on which the fight against racism and anti-Semitism are based.... Such acts are incompatible with democracy and human rights because they infringe the rights of others.

As a result, the complaint was found inadmissible on the basis of Article 17 of the Convention.

The fact that the ECtHR relies on Article 17 of the European Convention on Human Rights in its case law concerning the public dissemination of Holocaust denial is very significant. However, it simultaneously raises several doubts arising from the exceptional character of this provision. According to the case law of the Strasbourg Court, as well as the ideas underlying the Convention itself, Article 17 was designed to serve as a "last resort" in cases where the limitation clauses appended to those provisions of the Convention that grant specific rights and freedoms could no longer be applied or might be deemed insufficient. The essence of the meaning of Article 17 was expressed during the consideration of the complaint in De Becker v. Belgium, ${ }^{51}$ where the ECtHR emphasized that Article 17 was applicable only to those individuals who posed a threat to the democratic order of the states parties to the Convention.

The fact that the ECtHR regards Holocaust deniers as individuals who pose this kind of threat is a clear sign that the Strasbourg Court understands and is ready to fight the dangers resulting from Holocaust denial in Europe. However, a question arises as to the scope and wording of negationists' statements that are covered by Article 17. Would a similar line of argument apply to the efforts to negate the genocide that took place in Bosnia during the Balkan wars? The fact that the crime of genocide was committed in Bosnia at that time has also been proven beyond all reasonable doubt. ${ }^{52}$ Moreover, new provisions penalizing the negation of other genocides are being implemented by individual European states, as was the case with the French law prohibiting the negation of

50 Roger Garaudy v. France, App. No. 65831/01 (2003).

51 De Becker v. Belgium, App. No. 214/56 (1962).

52 In Prosecutor v. Radislav Krstic, Trial Chamber I, Judgment, IT-98-33 (2001), ICTY8, Aug. 2, 2001, the International Criminal Tribunal for the Former Yugoslavia found that genocide had been committed. It was upheld in Prosecutor v. Radislav Krstic, Appeals Chamber, Judgment, IT-98-33 (2004), ICTY 7, Apr. 19, 2004, available at: <http://www.icty.org>. 
the genocide committed by the Turks against the Armenian people. ${ }^{53}$ Until now, the ECtHR has not been required to respond to this question, but it is most likely that it will soon face such challenges. Only then will it be possible to assert with certainty that the antisemitic character of Holocaust denial is a decisive factor on which the invocation of Article 17 of the Convention relies in the context of negationism.

\section{UN HUMAN RightS COMMITTEE AND HOLOCAUST DENIAL IN THE EUROPEAN CONTEXT}

The question of the freedom of speech of Holocaust deniers in the European context was also examined by an international, quasi-judicial body in the universal human rights protection system, namely the UN Human Rights Committee, after Robert Faurisson, another prominent representative of the European negationist movement, submitted a complaint to the Committee. ${ }^{54}$ Shortly after the so-called Gayssot Act, which penalizes Holocaust denial0, had been adopted in France, Faurisson gave a press interview in which he stated, inter alia, that he did not believe in the existence of a "policy of extermination of Jews" and "magical gas chambers." Eventually, a French court fined Faurisson.

During the proceedings before of the UN Committee, where Faurisson submitted his complaint, France raised the issue of the admissibility of the communication, arguing that it should be dismissed as inconsistent ratione materiae with the provisions of the International Covenant on Civil and Political Rights. ${ }^{55}$ It invoked Article 5 of the Covenant, which is similar in character and effect to Article 17 of the European Convention on Human Rights and stipulates that: "Nothing in the present Covenant may be interpreted as implying for any State, group or person any right to engage in any activity or perform any act aimed at the destruction of any of the rights and freedoms recognized herein...." It was emphasized that Faurisson's complaint should be treated in the same manner as similar complaints submitted to the Strasbourg Court and found inadmissible. Article 20 of the Covenant was also invoked. This provision explicitly imposes an obligation on all states parties to prohibit by law any war propaganda, as well as any advocacy of national, racial, or religious hatred that constitutes incitement to discrimination, hostility, or violence. However, the UN Human Rights Committee did not share the position of the French government and found the complaint admissible as regards the alleged violation of Faurisson's freedom of speech, guaranteed by Article 19 of the Covenant.

When considering the merits of the communication, the Committee stated that, in certain circumstances, the Gayssot Act might lead to a breach of the Covenant, as it limits freedom of speech too extensively. However, it also emphasized that, in the case of Roger Faurisson, the French courts had managed to eliminate such a risk by carefully analyzing all circumstances of the case. Furthermore, the Committee referred to its

53 The French bill on Armenian genocide denial is available at: $<\mathrm{http}: / / \mathrm{www}$.assemblee-nationale. fr/12/dossiers/reconnaissance_genocide_armenien_1915_loi_2001.asp > (in French). See also reports on a Turkish politician fined over genocide denial by the Swiss courts, available at: $<\mathrm{http}: / / \mathrm{www}$. swissinfo.ch/eng/Home/Archive/Court_confirms_verdict_against_Perincek.html?cid=6324022>.

54 Robert Faurisson v. France, App. No. 550/1993 (1996).

55 International Covenant on Civil and Political Rights, adopted and opened for signature, ratification and accession by General Assembly resolution 2200A (XXI) of 16 December 1966, available at: <http://www2.ohchr.org/english/law/ccpr.htm>. 
General Comment No. 10, which explicitly states that restrictions on the freedom of speech may be necessary in order to protect and ensure the interests of other persons and specific groups as a whole. ${ }^{56}$ Restricting the free speech of a Holocaust denier thus served to protect the right of the Jewish community in France to live a life free of fear and antisemitism. The statements made by Faurisson, interpreted in their wider context, stirred antisemitic feelings. As a result, the Committee decided that France did not violate any provisions of the Covenant. However, the Committee's decision was accompanied by a number of individual opinions of the Committee's members, who emphasized their concerns regarding the overly restrictive nature of French legal provisions penalizing Holocaust denial. Although they all agreed with the final conclusion of the Committee, they perceived the Gayssot Act as a potential threat to freedom of speech if used in a context other than the penalization of antisemitism.

One of the most striking elements of the Committee's decision in Faurisson's case was a statement by Professor Thomas Buergenthal, who is currently a judge of the International Court of Justice in the Hague: "As a survivor of the concentration camps of Auschwitz and Sachsenhausen whose father, maternal grandparents and many other family members were killed in the Nazi Holocaust, I have no choice but to recluse myself from participating in the decision of this case." This powerful confession of a Holocaust survivor, forced by the Holocaust denier's demand for protection of his antisemitic views in front of a UN human rights protection body, is indeed a symbolic one.

\section{CONCLUSIONS}

The question of the legitimacy of penalizing Holocaust denial is part of a broader doctrinal dispute in which the views of those who advocate the unrestricted freedom of speech of the negationists clash with the views of those who see the need to use a specific legal barrier in cases of drastic abuse of this freedom. This question is also constantly present within European states. In 2007, the Constitutional Court of Spain found a legal provision penalizing Holocaust denial unconstitutional. ${ }^{57}$ It stated that the danger of restricting free public debate within the democratic society of Spain overrides the need to counteract dissemination of Holocaust denial.

Beyond such free speech violation controversies, the fact that European legislators and judges are having serious doubts about this issue is also caused by another disturbing phenomenon, namely the multiplication of so-called "memory laws" in many European states. In recent times, an increasing number of legal provisions penalizing various "historical lies" have been adopted, some of which are far from rational. ${ }^{58}$ For example, as already noted above, under the Turkish Penal Code it is forbidden to publicly claim that the Armenian genocide ever took place. In 2005, a world-famous Turkish

56 General Comment No. 10: Freedom of expression, Art. 19, available at: <http://www2.ohchr. org/english/bodies/hrc/comments.htm>.

57 Constitutional Court of Spain, Judgment No. 235/2007, Nov. 7, 2007, available at: <http:// www.tribunalconstitucional.es/ES/JURISPRUDENCIA/RESTRAD/Paginas/JCC2352007en.aspx>.

58 See, e.g., Timothy Garthon Ash, "This is the moment for Europe to dismantle taboos, not erect them," The Guardian online, Oct. 19, 2006, available at: <http://www.guardian.co.uk/commentis free/2006/oct/19/comment.france>; "Editorial: Turkey, Armenia and Denial," New York Times online, May 16, 2006, available at: <http://www.nytimes.com/2006/05/16/opinion/16tue3.html>. 
writer and Noble Prize winner, Orhan Pamuk, was accused of publicly insulting Turkishness after stating in an interview that the murder of Armenians by the Turks was nothing short of genocide..$^{59}$ Grotesque as it may seem, at the same time France and Switzerland decided to penalize public denial of the Armenian genocide. The Russian parliament, on the other hand, has recently started drafting a law that could result in penalizing any critique of the actions of the Soviets in World War II - an unprecedented abuse of the truth from the Polish perspective. ${ }^{60}$ Which historical claims deserves legal protection? When does justified action against the abuse of historical truth turn into state-sponsored decreeing of an official version of history? These questions remain open, as the answers depend to a large extent on the specific historical context and the individual "memory law."

And yet, in the case of Holocaust denial, it is not enough to speak of falsifying facts and historical events. It is an unprecedented phenomenon that has spread all over the world for a very specific reason: to incite hatred of one particular nation - the Jewish people. The fact that Holocaust denial is currently part of official state doctrine in Iran is terrifying. This makes it all the more problematic that a fellow at one of America's most prestigious universities organized a meeting for students with the president of Iran, the very same person who has been saying for years that the Jews invented Holocaust and that Israel should be wiped off the world map. ${ }^{61}$

The antisemitic motivation for spreading Holocaust denial is the most convincing reason for the need to punish negationists for their words. What is debatable is whether or not they should be punished by imprisonment. It is possible that establishing very high financial penalties for denying the Holocaust, combined with an obligation to publicize and publicly announce the judicial ruling in question, could also produce the desired effect. At the same time, we should be wary of the idea that it is only necessary to penalize Holocaust denial. Even though Germany has a special responsibility in this area, denying the murder of millions of Jews has the same objective and the same harrowing effects all over the world.

It is clear that the problem of penalizing Holocaust denial does not merely come down to making arguments for or against such penalization. The very shape of the particular legal provision, including the form and scope of the penal sanction and the manner in which national courts and law enforcement agencies use the available legal instruments, is equally important and controversial. These are the elements that most often determine whether or not the boundary between justified restriction of freedom of speech and excessive penal repression has been crossed.

59 The charges against the writer caused an international outcry and led to public reactions by the European Parliament and the European Union. See European Parliament, Question for written answer to the Commission, Subject: Turkish court judgment against Orhan Pamuk, E-003754/2011, Apr. 19, 2011, available at: <http://www.europarl.europa.eu/sides/getDoc.do?pubRef=-//EP//TEXT+ WQ+E-2011-003754+0+DOC+XML+V0//EN\&language=EN $>$.

60 Andrew Osborn, "Medvedev Creates History Commission," Wall Street Journal online, May 21, 2009, available at: <http://online.wsj.com/article/SB124277297306236553.html>.

61 Sam Greenberg, "Relating to Iran, in seminar and in person. Jackson Institute fellow arranges private meeting with Iranian president for students in her graduate seminar," Yale Daily News, Sep. 27, 2010, available at: <http://www.yaledailynews.com/news/2010/sep/27/relating-to-iran-in-seminarand-in-person>. 


\title{
The Judeo-Masonic Enemy in Francoist Propaganda (1936-1945)
}

\author{
Javier Domínguez Arribas*
}

\section{INTRODUCTION}

Between the beginning of the Spanish Civil War and the end of the Second World War, Francoist propaganda depicted Jews and Freemasons as two closely linked forces that conspired tirelessly against Spain. They were considered responsible for all the evils that afflicted the country, together with the leftists. While the "Reds" were an obvious and significant enemy for the nationalist forces, there were no more than about 5,000 Spanish Freemasons in 1936, and their influence in Spanish public affairs was limited, at least as an organization (although the individual influence of some Freemasons is another issue). However, their fate was the same as that of the "Communists": relentless repression. ${ }^{1}$ The case of the Jews is even more surprising. The antisemitic propaganda of the early days of the Franco regime took place in a country where almost no Jews had lived since their expulsion by the Catholic monarchs in 1492. Furthermore, most members of the tiny Jewish community in the Iberian Peninsula in 1936 had arrived just a short time previously, coming mostly from Hitler's Germany. Their number, although impossible to establish precisely, has been estimated at close to $6,000 .^{2}$ In spite of the violent rhetoric against Jews, the regime did not systematically implement discriminatory policies against them. Above all, the Franco government did not facilitate Nazi antisemitic persecution during the Second World War, while some Spanish diplomats in fact protected Jews in danger. ${ }^{3}$ Why, then, were two groups that were so small, so different, and so differently treated by the regime, presented together by official propaganda as the powerful Judeo-Masonic enemy to be fought? This, among other aspects, is the focus of the research presented in this paper. ${ }^{4}$

* Associate Professor, University of Paris XIII-CRESC.

1 See José Antonio Ferrer Benimeli, "Franco y la masonería," in Josep Fontana, España bajo el franquismo, Barcelona, Crítica, 1986, pp. 246-268 at p. 268. I would like to thank my colleague Susan Pickford for having corrected my English. A preliminary Spanish version of this paper may be consulted in VII Encuentro de Investigadores sobre el franquismo, Santiago de Compostela, Fundación 10 de Marzo, 2011 (CD-ROM).

2 Haim Avni, Spain, the Jews, and Franco, Philadelphia, The Jewish Publication Society of America, 1982, p. 45 .

3 See Bernd Rother, Franco y el Holocausto, Madrid, Marcial Pons, 2005 (German orig. ed. 2001).

4 This research was conducted at the École des Hautes Études en Sciences Sociales (School for Advanced Studies in the Social Sciences, Paris) and culminated in a PhD thesis entitled "L'ennemi 
This research is devoted to antisemitic and anti-Masonic propaganda during the first period of the Franco regime (1936-1945). In order to respect the internal logic of Francoist discourse, it has been necessary to make a joint analysis of the representations of Jews and Freemasons, because antisemitic and anti-Masonic references were very often intertwined in the regime's propaganda. Taking this as my starting point, my research has been essentially based on a cross-analysis of two kinds of primary sources: first, the printed sources that made the dissemination of antisemitic and anti-Masonic propaganda possible, in particular the press and books that denounced the intrigues of Jews and Freemasons; and, second, several archival sources that reveal the precise nature of the links between the organization of Francoist propaganda and the creation of an antiJudeo-Masonic discourse. ${ }^{5}$

The resultant research work, published in Spanish under the title of El enemigo judeomasónico en la propaganda franquista (1936-1945), ${ }^{6}$ is divided in four parts, each consisting of two chapters. The first part studies two preliminary issues essential for a thorough understanding of the topic: the antisemitic and anti-Masonic tradition that later inspired Franco's propaganda (Chapter I) and Franco's personal attitudes toward Jews and Masons (Chapter II).

The second and the third parts follow a chronological pattern, focusing on the Spanish Civil War and the Second World War respectively. The situation of the Jews and the Freemasons is briefly presented at the beginning of each part, which share a common structure based on the propaganda means under analysis. Thus, in each of these two parts, one chapter focuses on the role of the press in the transmission of antisemitic and anti-Masonic ideas (Chapters III and V), while the other focuses on the most important official and unofficial publishing houses involved in disseminating these ideas in books and pamphlets in each period (Chapters IV and VI).

Finally, the fourth and final part moves beyond the chronological pattern to apply an interpretative scheme based on the following questions: what was the purpose of Franco's propaganda about Jews and Masons, and what were its functions? Two of the functions of antisemitic and anti-Masonic propaganda are analyzed in detail: first, the use of anti-Masonic discourse within the Francoist coalition as a political weapon (Chapter VII); and, second, the invocation of a common Judeo-Masonic enemy as a means of cohesion, uniting the different factions of the coalition (Chapter VIII).

\section{THE JUDEO-MASONIC ENEMY}

Among other results of this research, it appears that the new Francoist regime led an unprecedented propaganda effort to present the imaginary Judeo-Masonic consortium as

judéo-maçonnique dans la propagande franquiste (1936-1945)," defended on 6 January 2006 in front of a jury consisting of Michel Ralle, Marie-Claude Chaput, Gonzalo Álvarez Chillida, Jordi Canal, and Bernard Vincent (research director). This thesis was awarded a distinction.

5 The four main archives consulted are the General Administration Archive (AGA) in Alcalá de Henares, the General Military Archive (AGM) in Ávila, the Francisco Franco Foundation Archive (AFF) in Madrid, and the General Archive of the Spanish Civil War, currently the Historical Memory Documentary Centre (CDMH) in Salamanca.

6 Javier Domínguez Arribas, El enemigo judeo-masónico en la propaganda franquista (1936-1945), Madrid, Marcial Pons, 2009. 
one of the major enemies of the regime and, by extension, Spain. But the antisemitic and anti-Masonic themes were not new at all. In some cases, they came from a centuries-old tradition, although the modern configuration of the Judeo-Masonic myth mainly emerged in the second half of the 19th century, due principally to a small group of French Catholic authors who acquired a strong influence in Spain. During the Second Spanish Republic (1931-1936), the anti-liberal radicalization of the right wing reinforced this myth. ${ }^{7}$ One of the few new aspects of Francoism regarding the transmission of anti-Judeo-Masonic theories is the fact that they were disseminated by the authorities for the first time.

It has also been demonstrated that the Judeo-Masonic enemy proved especially useful as a "substitute enemy" in cases where anti-Communist propaganda may have been counterproductive. This refers in particular to leaflets dropped behind the Republican lines during the Civil War, a means of persuasion in which anti-Communist arguments were useless, as well as to the context of the German-Soviet Pact (from August 1939 to June 1941), when Francoist propaganda had to tone down its anti-Bolshevik attacks. ${ }^{8}$

\section{INFLUENCES}

Several influences of a very different nature made their mark on Franco's propagandists. First of all, they were the heirs of the long reactionary tradition that had given rise to the Judeo-Masonic myth. Coming from this ideological background, the Protocols of the Elders of Zion exerted a decisive influence in Spain, as did the work of French Catholic authors Ernest Jouin and Léon de Poncins. ${ }^{9}$

Nazi Germany's influence is also apparent in the antisemitic propaganda produced in Spain. The Third Reich bribed journalists and financed the publication of works of propaganda during both the Spanish Civil War and the Second World War. ${ }^{10}$ However, the significance of Nazi influence should not be exaggerated, as has often been the case, in particular in discussions that hold it to be the sole form of antisemitic (and even antiMasonic) propaganda spread in Spain, especially through the Falange, the Spanish fascist party. An analysis of Francoist propaganda regarding Jews and Freemasons shows that the anti-Judeo-Masonism of the early years of the regime did not emerge $e x$ novo and that the Falangists were not its sole distributors, as has sometimes been suggested. It is true that Nazi antisemitic propaganda was available in Spain (sometimes transmitted through the Falange), but it came into a field that was already fertile. In fact, external factors did have some influence on the varying pace of anti-Judeo-Masonic propaganda prior to 1945, but they did not determine it.

7 See Jacques Lemaire, L'antimaçonnisme. Aspects généraux (1738-1998), Paris, Éditions Maçonniques de France, 1998; and Gonzalo Álvarez Chillida, El Antisemitismo en España. La imagen del judío (1812-2002), Madrid, Marcial Pons, 2002.

8 On the impact of the German-Soviet Pact on Francoist propaganda, see Benito Bermejo, "L'Espagne," in La propagande sous Vichy 1940-1944, Nanterre, BDIC, 1990, pp. 263-271 at p. 268; and Gabriel Jackson, Aproximación a la España contemporánea 1898-1975, Barcelona, Grijalbo, 1981, p. 130. Several examples of leaflets thrown to Republican fighters can be found in AGM, Cuartel General del Generalísimo (CGG), 3/223 and 5/283-284.

9 One of the latter's books was particularly influential: Léon de Poncins, Las fuerzas secretas de la revolución: F.M.-judaísmo, Madrid, Fax, 1932 (French orig. ed. 1928).

10 See, for instance, Ingrid Schulze Schneider, “La propaganda alemana en España 1942-1944," Espacio, Tiempo y Forma, Serie V, Historia Contemporánea, VII, 1994, pp. 371-386. 
Among the Francoist political factions engaged in spreading anti-Judeo-Masonic theories, the Falangists were the most active. This is due to the control they exerted over official propaganda between 1938 and 1945 rather than to any specific obsession with antisemitic issues, even less so anti-Masonic ones. In fact, these themes did not occupy a central position in the original thinking of the Falangists (with the sole exception of Onésimo Redondo). ${ }^{11}$ When they did use it for propaganda purposes after 1936, they essentially returned to the religious arguments that the most traditional forms of Catholicism, in particular Integrists and Carlists, had been espousing for several decades. Even then, their arguments sometimes lacked conviction. The predominant accusations against the Judeo-Masonic enemy, including those of the Falangists, did not have the modern nature claimed by fascism.

In sum, although the Falangists played a main role in the transmission of anti-JudeoMasonic ideas, the data tends to underline the significance of another ideological current whose influence on Francoist discourse has often been underestimated: traditionalist thought. The cultural and ideological origins of the Judeo-Masonic myth, as used in the early years of the regime, were not fascist; rather, they lay in the reactionary ideas of national Catholicism. ${ }^{12}$

\section{FRANCO'S POSITION}

The dictator's personal position should not be overlooked when it comes to explaining the use of the Judeo-Masonic enemy in the regime's propaganda, although his attitudes toward Jews and Freemasons were relatively independent from the ideas transmitted by his propagandists. In particular, Franco does not seem to have given much credit to the theory that linked Jews and Masons; he had very different points of view regarding each group (which has often masked the fact that the regime's propaganda did link them). The Jews never occupied an important place in his thought and he even showed some understanding of the Sephardim, although this was because of their Spanish roots rather than their Jewishness. ${ }^{13}$ However, this did not prevent him from using antisemitic themes for propaganda purposes, as he did in various speeches, especially between 1939 and 1943, several of the articles he wrote for the newspaper Arriba in 1949 and 1950, and even in instructions given to the press during the Civil War that have only recently come to light. ${ }^{14}$

Franco considered Freemasonry his worst enemy, even worse than Communism, and the dictator's ideas about Freemasonry are essential in explaining the virulence of the propaganda against the organization, in which he personally took part. Franco wrote numerous anti-Masonic texts, beginning at the time of the Civil War, for use as the basis

11 See Álvarez Chillida, op. cit., at pp. 340-343.

12 National Catholicism is the ideology that considers Catholicism as the essence of the Spanish nation.

13 See especially Francisco Franco Bahamonde, Papeles de la guerra de Marruecos. Diario de una bandera. La hora de Xauen. Diario de Alhucemas, Madrid, Fundación Nacional Francisco Franco, 1986, pp. 191-192.

14 The articles were published under a pseudonym and then compiled in J. Boor, Masonería, Madrid, Gráficas Valera, 1952. Some of the instructions for the press can be seen in AGM, CGG, $5 / 284(20)$. 
for leaflets and instructions to the press. He later decided to publish his own antiMasonic articles in Arriba. ${ }^{15}$ One of the most significant results of this work was the detailed analysis of a previously unknown element that played a decisive role in shaping Franco's thoughts and acts on Freemasonry, beginning in the early 1940s. This was the spy network known as APIS, which transmitted dozens of fake Masonic documents to the dictator over a period of more than 20 years, with the partisan aim of influencing him in an anti-Falangist and anti-Juanist direction. ${ }^{16}$

\section{PROPAGANDA MEANS}

Several means were used to transmit anti-Judeo-Masonic theories between 1936 and 1945. Visual media such as posters or films do not seem to have played a significant role, with rare exceptions, while oral forms of propaganda, such as lectures, talks, and speeches, were used to disseminate these theories among very different audiences. Speeches and lectures about the misdeeds of the Jewish and Masonic enemy were sometimes broadcast on radio, particularly during the Civil War, considerably extending their audience and even reaching the Republican side. ${ }^{17}$ Leaflets were also distributed in enemy areas during the conflict to encourage the desertion of militiamen; some contained invectives against Jews and Masons, who were accused of dominating Republican Spain. Further leaflets attacking the Judeo-Masonic enemy were distributed later on, for instance during a propaganda campaign for unity between the army and the Falange in the winter of $1941-1942 .^{18}$

The use of antisemitic and anti-Masonic discourse by the Franco regime is particularly evident when we examine newspapers and, above all, the consignas (instructions) sent to them by the official press and propaganda machine, during both the Spanish Civil War and the Second World War. During the first period, antisemitic and anti-Masonic themes appeared in the press on an almost daily basis, especially in 1937, due to the constant intervention of the new Francoist regime. The instructions were a way of launching very different campaigns with different goals. One of them, for instance, was to discredit initiatives at mediation in the eyes of public opinion, while another was to avoid any dissidence, warning Spaniards against the enemy's infiltration of the new regime. ${ }^{19}$ During the Second World War, attacks against Jews and Masons followed ever more divergent paths in the Francoist press; although still abundant, they were no longer published on a daily basis and tailed off considerably toward the end of the conflict. The Franco regime's use of such themes, especially antisemitic ones, was then increasingly shaped by developments in the international context, a trend already begun at the end of the Civil War. ${ }^{20}$

15 Some of these texts and instructions can be seen in AGM, CGG, 5/283 (10) and 5/284 (27).

16 The juanistas were the supporters of Juan de Borbón, son of Alphonse XIII and pretender to the Spanish throne. On the APIS network, see CDMH, Presidencia, 91; AFF, 965, 1061, 1244, 1246, 5071, 5072, 5073, 9459, 11389, etc.

17 An example of a broadcast of an anti-Masonic lecture can be found in AGM, CGG, 2986 (1).

18 AGA, Cultura, 21/119.

19 There were press campaigns against mediation in the springs of 1937 and 1938 and October 1938. Anti-Judeo-Masonic arguments played an important role in all three cases.

20 See Domínguez Arribas, op. cit., at ch. V. 
In parallel with this press activity, two publishing houses at the service of the Franco regime played a major role in disseminating anti-Judeo-Masonic theories: Ediciones Antisectarias (1936-1939) and Ediciones Toledo (1941-1943). The former's links to the regime were unofficial, unlike the latter, which concealed its origins to increase its persuasive power. At Ediciones Antisectarias, the ideological positions of traditionalism and Catholic integrism prevailed (despite the support that this collection received from the pro-Falangist minister Serrano Suñer), while Ediciones Toledo was controlled by the Falangists, although they were watered down and submissive to Franco. Therefore, each series of works distinguished itself by an orientation that was primarily Catholic in the case of Antisectarias and Falangist in the case of Toledo. However, with regard to Jews and Freemasons, the contents were not very different between the two publishing houses, being mainly characterized by anti-Judeo-Masonism with Christian roots.

The leading authors of the two publishing houses had very different careers, but they did have some points in common. Juan Tusquets, a priest, managed Ediciones Antisectarias and wrote the most important volumes in the collection, while Francisco Ferrari Billoch, himself a former Mason, was an anti-Judeo-Masonic expert for Ediciones Toledo, among other contributors. He wrote a single pamphlet under his own name for Toledo, but a number of anonymous brochures must also be attributed to him. Both Tusquets and Ferrari had begun their anti-Masonic (and antisemitic) careers prior to the uprising of July 1936, inspired by a rigid view of Catholicism. ${ }^{21}$

If we consider propaganda means as a whole, it is apparent that the Falangists' gradual take-over of the propaganda department during the war and, particularly, in its aftermath did not imply a significant change in the antisemitic and anti-Masonic themes that appeared in Francoist discourse. Contrary to what one might expect, the period characterized by the highest "anti-Judeo-Masonic inflation" is that prior to the Falange's control of the propaganda machine, that is, during the first half of the Civil War.

\section{THE FUNCTIONS OF ANTI-JUDEO-MASONIC PROPAGANDA}

If the regime did spread violent discourse against Freemasons and Jews in its early years, it was because it stood to gain many advantages thereby. "Everything can be used from the enemy," says a fictional Franco in a story by a well-known Spanish writer. ${ }^{22}$ This assertion can be applied to the Judeo-Masonic enemy, which could even be used to achieve goals that were unattainable through the mere invocation of the Communist enemy, as we have seen.

Among the functions of antisemitic and anti-Masonic propaganda, those addressed to the Spanish population as a whole must be considered first. The explanatory function is maybe the most evident of all. Since it first emerged in the 19th century, the Judeo-

21 Ibid., at chs. IV and VI. A preliminary version of these chapters may be consulted in Javier Domínguez Arribas, "Juan Tusquets y sus Ediciones Antisectarias (1936-1939)," in J.A. Ferrer Benimeli (ed.), La masonería española en la época de Sagasta, Zaragoza, Gobierno de Aragón, 2007, vol. II, pp. 1157-1196; and Javier Domínguez Arribas, "La propaganda anti-judeo-masónica durante el primer franquismo: el caso de Ediciones Toledo (1941-1943)," in J.A. Ferrer Benimeli (ed.), La masonería en Madrid y en España del siglo XVIII al XXI, Zaragoza, Gobierno de Aragón, 2004, vol. II, pp. 1165-1194.

22 Francisco Umbral, Leyenda del César Visionario, Barcelona, Bibliotex, 2001, p. 70 (1st ed., 1991). 
Masonic myth provided simple and comprehensive explanations for extremely complex situations, and this fundamental use continued in Franco's Spain after 1936. These supposed Judeo-Masonic plots were a way of explaining the unexplainable, from the criticism against Nationalists by some foreign Catholics during the Civil War, which was considered incomprehensible, to the black market, corruption, and hunger in the postwar period. ${ }^{23}$

The legitimating function, equally obvious, was particularly necessary in the context of a state under construction that was imposing its rule through civil war. Alleged Judeo-Masonic control over Republican Spain legitimated the war effort and the establishment of a new regime, as well as the specific measures adopted by it, especially in terms of repression. The analysis of Ediciones Toledo has shown that some brochures justified specific repressive measures. ${ }^{24}$

The central role of the repressive function in anti-Judeo-Masonic propaganda must likewise be emphasized. Countless examples prove the existence of close links between propaganda and repression, although the former directed its invectives against both Jews and Masons and the second affected only the latter. The lists of Freemasons published by the Nationalist press at the beginning of the Civil War may be included in the "thread that leads from propaganda to repression," to quote Dominique Rossignol, and the same is true of the works of Tusquets and Ferrari Billoch, which were used by the courts as evidence to prosecute Freemasons. ${ }^{25}$ Another fact is even more significant: both authors actively participated in the repression of the "sect" during the Civil War, along with other anti-Judeo-Masonic propagandists. Tusquets simultaneously managed the anti-Masonic section of Franco's military intelligence and the collection that actually became its propaganda organ, Ediciones Antisectarias. ${ }^{26}$

Other functions were specific to the factions that were part of the authoritarian coalition. Within this coalition, propaganda against Jews and Freemasons principally served two contradictory functions. On the one hand, the Judeo-Masonic common enemy was invoked to unite the different factions that supported Franco. In critical periods, those in charge of propaganda, and particularly the Falangists loyal to Franco who took over in 1941, aimed to ease tensions and to strengthen the regime's stability by joining forces against this mythical figure. Both Ediciones Antisectarias and Ediciones Toledo, just like newspapers and other means of propaganda, published this kind of call for unity, meant particularly to neutralize existing conflicts between the military and the Falangists, as well as between the latter and all the other "families" in the nationalist coalition.

The principal function of anti-Judeo-Masonic propaganda within the Francoist coalition, however, was completely different from, and even contrary to, the aforementioned function. Its antisemitic and especially anti-Masonic discourse was not only directed against the various enemies of the New Spain (from Republican leaders to liberal Catho-

23 See, for instance, Juan Tusquets, Masones y pacifistas, Burgos, Ediciones Antisectarias, 1939; and La garra del capitalismo judío. Sus procedimientos y efectos en el momento actual, Madrid, Ediciones Toledo, 1943.

24 For example, La masonería en acción, Madrid, Ediciones Toledo, 1941.

25 Dominique Rossignol, Histoire de la propagande en France de 1940 à 1944. L'utopie Pétain, Paris, Presses Universitaires de France, 1991, p. 254.

26 On the role of Tusquets in the anti-Masonic section of the Military Information Service (SIM), see AGM, CGG, 2986 and 2964 (2). 
lics). In fact, this kind of argument was also used by several factions of the authoritarian coalition as a powerful weapon to launch a more or less subtle attack on the opposing factions of the same coalition. This internal use can be seen in the press from the Civil War on, when Falangist newspapers presented anti-Judeo-Masonic arguments to criticize the former members of the CEDA (a rightist Catholic party), and vice versa. Ediciones Antisectarias did the same with the Falange and with one of its foreign models, Nazism. However, it was in the period of the Second World War that accusations of links with Freemasonry (Judaism being progressively left aside) became especially frequent within the Francoist conglomerate. Reading between the lines, it is possible to find this kind of insinuation in La masonería en acción (Freemasonry in action) (1941), one of Ediciones Toledo's brochures, as well as in newspapers, sometimes due to instructions from the Falangists that controlled the press and propaganda offices. Everybody accused everybody else, although Falangists and Don Juan's supporters seem to have been the main victims of these attacks, which in some cases even took the form of specific repressive action.

\section{CONCLUSION}

In sum, the Judeo-Masonic enemy, as it appeared in early Francoist propaganda, worked within the authoritarian coalition as a mechanism to regulate tensions and control internal dissidence. Sometimes, its invocation as a common enemy was able to reduce conflict; at other times, anti-Judeo-Masonic rhetoric acted as a safety valve, allowing tensions to be expressed (and maybe even resolved) through accusations of Freemasonry such as those directed against Pedro Sainz Rodríguez or Gerardo Salvador Merino, two high officials of the regime. After this kind of accusation, it was time to expect a possible intervention in favor of one faction or another by the supreme arbitrator-the Caudillo, whose anti-Masonic obsession was familiar to all. Francoism clearly emerges from this research as an extremely conflictive and non-uniform reality. This, in my opinion, is not to downplay its dictatorial and repressive nature at all. 


\title{
"Artisans ... for Antichrist": Jews, Radical Catholic Traditionalists, and the Extreme Right
}

\author{
Mark Weitzman*
}

The Israeli historian, Israel J. Yuval, recently wrote:

The Christian-Jewish debate that started nineteen hundred years ago, in our day came to a conciliatory close. ... In one fell swoop, the anti-Jewish position of Christianity became reprehensible and illegitimate.... Ours is thus the first generation of scholars that can and may discuss the Christian-Jewish debate from a certain remove ... a postpolemical age. ${ }^{1}$

This appraisal helped spur Yuval to write his recent controversial book Two Nations in Your Womb: Perceptions of Jews and Christians in late Antiquity and the Middle Ages. Yuval based his optimistic assessment on the strength of the reforms in Catholicism that stemmed from the adoption by the Second Vatican Council in 1965 of the document known as Nostra Aetate. Nostra Aetate in Michael Phayer's words, was the "revolutionary" document that signified "the Catholic church's reversal of its 2,000 year tradition of antisemitism." ${ }^{2}$

Yet recent events in the relationship between Catholics and Jews could well cause one to wonder about the optimism inherent in Yuval's pronouncement. For, while the established Catholic Church is still officially committed to the teachings of Nostra Aetate, the opponents of that document and of "modernity" in general have continued their fight and appear to have gained, if not a foothold, at least a hearing in the Vatican today. And, since in the view of these radical Catholic traditionalists "[i]nternational Judaism wants to radically defeat Christianity and to be its substitute" using tools like the Free-

* Director of Government Affairs, Simon Wiesenthal Center. My thanks to Mary Christine Athans, who so generously shared her important work on Denis Fahey and Charles Coughlin, for her encouragement and incisive criticism. In addition, I owe thanks to Heidi Beirich, who was also extremely generous in sharing her research on radical Catholic traditionalists, and to Margot Gendreau and Beverly Geller for their research assistance.

The title of this paper is taken from a statement by Bishop Bernard Tissier de Mallerais of the Society of Saint Pius X, who said in 1997 "that the Jews are the most active artisans for the coming of Antichrist," quoted in Thomas C. Fox, "Lefebvre movement: long, troubled history with Judaism," NCR Online, Jan. 26, 2009, available at: <http://ncronline.org/node/3180>.

1 Israel J. Yuval, Two Nations in Your Womb: Perceptions of Jews and Christians in Late Antiquity and the Middle Ages (Berkeley and Los Angeles, 2008) pp. 20-21.

2 Michael Phayer, The Catholic Church and the Holocaust, 1930-1965 (Bloomington, 2001) p. 203. 
masons, it is in their views on Jews and Judaism that we can find the most profound expression of their radical rejection of Nostra Aetate, Vatican II, and the modern virtues of democracy and tolerance. ${ }^{3}$

Although the firestorm of publicity aroused in recent years by the actor Mel Gibson's film "The Passion of the Christ" and the more recent Holocaust denial remarks of Bishop Richard Williamson have died down, they serve to remind us that for some Catholics the subsequent statements and reforms by the Church in regard to the Jewish people, such as Nostra Aetate and its successor documents, are still unacceptable, and the earlier

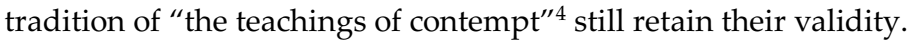

An even more basic question is, of course, that of definition. Following the sociologist Michael Cuneo, I begin with the loose definition of those who have rejected the reforms of Vatican II and "entered into schism from the institutional church." However, I should stress that the focus of this article will be on only examining the attitudes of those extreme traditionalists toward Jews, Judaism, and the related area of religious freedom. ${ }^{5}$

The Society of Saint Pius X (SSPX) has become the locus of the extreme Catholic traditionalist world. It was created in 1970 by Archbishop Marcel Lefebvre, who first came to attention when he refused to sign the Vatican II statement on Religious Liberty and the Church in the Modern World. ${ }^{6}$ As a result, in 1970, he created a traditionalist seminary in Econe, Switzerland, and in the same year he founded the Society of Saint Pius X. In 1973 and 1974, the SSPX came to the United States, with chapels being established in California, Texas, and New York. Lefebvre continued to publicly criticize the reforms of Vatican II, including the liturgical changes, and came into more and more overt conflict with Rome. He was ordered to close down his Swiss seminary in 1974 by Pope Paul VI but refused, and as a result his priestly functions were suspended in 1976. This did not stop Lefebvre, who upped the ante in 1983 by threatening to consecrate a successor.

Trying a different response, a year later Pope John Paul II reintroduced, under some conditions, the Tridentine (Latin) Mass, which was a gesture of conciliation to the traditionalists. Lefebvre and the traditionalists were not reconciled however, and three years later Lefebvre again threatened to consecrate a successor. This time the Vatican responded by entering into negotiations with the group, and indeed, on May 5, 1988, Lefebvre signed an agreement that required him to acknowledge his loyalty to the Vatican and to accept the new Mass as legitimate. In return, the SSPX was to be recognized and allowed to continue to use the Tridentine Mass in its services. The very next day, Lefebvre repudiated the agreement, and on June 30, 1988 he consecrated four bishops, in defiance of Rome's authority. This time, the Vatican responded forcefully, excommunicating Lefebvre and his priests and putting the SSPX into a state of schism. ${ }^{7}$ Lefebvre died in 1991, but by then the SSPX had become established and was able to withstand the loss of its founder. Bishop Bernard Fellay (Swiss) was elected as Superior General in 1994 and was re-elected in 2006.

3 Letter of Bishop Gerald Sigaud to Cardinal Tardini, Aug. 22, 1959, posted under the title "What Vatican II Should Have Done," available at: <http://www.sspx.org/MISCELLANEOUS/what vaticaniishould have done.htm>.

4 See Jules Isaac's seminal work, The Teachings of Contempt (New York, 1964).

5 Michael Cuneo, Smoke of Satan (Baltimore, 1999) p. 6.

6 Ibid., p. 91.

7 Ibid., pp. 91-92. 
The most recent firestorm erupted when Bishop Richard Williamson of the SSPX questioned the reality of the Holocaust. Williamson was one of the four bishops consecrated by Lefebvre in 1988. In January of 2009, Pope Benedict XVI lifted the excommunications; however, on that same day an interview with Williamson aired on Swedish TV in which he said: "I believe that the historical evidence is strongly against, is hugely against six million Jews having been deliberately gassed in gas chambers as a deliberate policy of Adolf Hitler," 8 and "I think that 200,000 to 300,000 Jews perished in Nazi concentration camps, but none of them in gas chambers." 9

The reaction from outraged Jews and others was immediate and grew upon exposure of Williamson's history of antisemitic comments, which included a belief in the accuracy of the notorious forgery The Protocols of the Elders of Zion. ${ }^{10}$ The resulting storm of criticism caused the Vatican to insist upon Williamson's renunciation of his Holocaust denial, which he has refused to do. However, in a letter in February 2009, he did say that "[o]bserving these consequences I can truthfully say that I regret having made such remarks," but he never indicated a recantation of his views. ${ }^{11}$ The negative import of Williamson's comments, coming amidst the ongoing reconciliation discussions with the Vatican, was also not lost on the SSPX leadership. Fellay weighed in on the matter by issuing a statement that said:

It's clear that a Catholic bishop cannot speak with ecclesiastical authority except on questions that regard faith and morals. Our Fraternity does not claim any authority on other matters. Its mission is the propagation and restoration of authentic Catholic doctrine, expressed in the dogmas of the faith. It's for this reason that we are known, accepted and respected in the entire world. The affirmations of Bishop Williamson do not reflect in any sense the position of our Fraternity. For this reason I have prohibited him, pending any new orders, from taking any public positions on political or historical questions. ${ }^{12}$

Yet Williamson's antisemitism was not new, or hidden. In a letter that was posted on the SSPX' seminary website, dated February 1, 1991, Williamsons reflected on the (first) Gulf War. First he pontificated that the war was instigated by Russia in an attempt to "kill with one stone ... obstacles to the advance of International Socialism," that would then allow "Russia to march through the now unguarded gateway to Europe." But hidden behind the Russian advance, according to Williamson, was another, even more sinister cause. "However, behind the Gulf War, and even behind Russia, may one not, thirdly, fear the looming figure of the Anti-Christ?" The war was a creation of "the many friends of Israel in the USA ... whooping for the United States to break the Arab strong man." Finally, Williamson puts these comments into a clear theological perspective:

8 See: <http://news.bbc.co.uk/nol/ukfs_news/hi/newsid_7870000/newsid_7878500/787580.stm>.

9 See:<http://www.telegraph.co.uk/news/worldnews/europe/vaticancityandholysee/4317996/ Pope-to-cancel-excommunication-of-rebel-bishops.html>.

10 See: <http://www.catholicherald.co.uk/articles/a0000226.shtml>. See also Steven L. Jacobs and Mark Weitzman, Dismantling the Big Lie: the Protocols of the Elders of Zion (Hoboken and Los Angeles, 2003) for current use of the Protocols as well as a detailed refutation of the text.

11 See: <http://news.bbc.co.uk/2/hi/europe/7915022.stm>.

12 Jan. 26, 2009, available at: <http://www.commonwealmagazine.org/blog/?p=2721>. 
Until [the Jews] recover their true messianic vocation [by accepting the Church] they may be expected to continue fanatically agitating, in accordance with their false messianic vocation of Jewish world domination. ... So we may fear their continuing to play their major part in the agitation of the East and the corruption of the West. ${ }^{13}$

In another letter to his supporters, written on the letterhead of the SSPX's St. Thomas Aquinas Seminary in Winona, Minnesota just a few months later, while discussing the media's debilitating influence on society (referring specifically to the confirmation hearings of Clarence Thomas for the Supreme Court), Williamson quoted the notorious Protocols of the Elders of Zion approvingly:

... it is indispensable to stir up the people's relations with their governments in all countries so as to utterly to exhaust humanity with dissension, hatred, struggle, envy ... so that the goyim see no other course open to them than to take refuge in our complete sovereignty in money and all else. ${ }^{14}$

Later in the same letter Williamson also cited Protocol 14 ("in countries known as progressive and enlightened, we have created a senseless, filthy, abominable literature"), referring to the "alternative life-style," which in Williamson's view is "so horrible as to cry to heaven for vengeance." Williamson's belief in the Protocols has remained consistent. A decade later, in a letter of May 1, 2009, Williamson wrote: “God puts in men's hands the 'Protocols of the Sages of Sion' ... if men want to know the truth, but few do." 15

Interestingly enough, Williamson's letters demonstrate not only his antisemitism but also overt racism and sexism. In an even more recent letter, he explains the 2005 unrest in France by writing: "So when white men give up on saving Jews, looking after other races and leading their womenfolk, it is altogether normal for them to be punished respectively by the domination of Jewish finance, by the refusal to follow of the nonwhite races and by rampant feminism."16 Finally, in the above-mentioned letter of February 1991, Williamson even combined two of those themes, noting criticism of his September letter in which he condemned women for wearing pants and jocularly compared it to criticism of his Holocaust denial, beginning the letter as follows:

Few of you will be surprised to learn that the September letter appealing to the women not to wear trousers caused a strong reaction, comparable only to the reaction of the Seminary letter which referred to scientific evidence that certain famous "holocaust gas-chambers" in Poland cannot have served as gas-chambers at all. ${ }^{17}$

While Fellay issued his statement in 2009, it is clear that Williamson's antisemitism was evident and publicly disseminated to the membership of the SSPX at least for the 18 years prior to Fellay's public statement. Furthermore, barring any evidence of prior repudiation or discipline of Williamson for his antisemitism, it is clear that Fellay was

13 See: <http://www.sspxsemianry.org/publications/letter/1991/February/February/shtml>.

14 Williamson, letter of Nov. 3, 1991, copy in author's possession.

15 Williamson, letter of May 1, 2000, available at: <http://www.sspx.ca/Documents/BishopWilliamson/May1-2000.htm>.

16 Williamson, "Denial of Christ Creates Chaos," available at: <http://www.dailycatholic.org/ issue/05Nov/nov14lit.htm>.

17 See note 13 above. 
being disingenuous at best when he claimed that " $[t]$ he affirmations of Bishop Williamson do not reflect in any sense the position of our Fraternity." In fact, the SSPX and the extremist Catholic traditionalist movement in general are shot through with antisemitism to such an extent that I believe it is possible to consider antisemitism as one of the foundational doctrines of the movement.

If we return to Lefebvre, we see that his record on Jews and Judaism was also highly questionable. In an August 31, 1985 letter to Pope John Paul II, he was quoted as having spoken approvingly of "both the World War II-era Vichy Regime in France and the farright National Front" and identified the contemporary enemies of the faith as "Jews, Communists and Freemasons." In that letter, Lefebvre also criticized "all the reforms carried out over 20 years within the church to please heretics, schismatics, false religions and declared enemies of the church, such as the Jews, the Communists and the Freemasons." 18

According to the same account, Lefebvre also gave an interview to the journal of the National Front in France, suggesting that Catholic opposition to a residence of Carmelite nuns at the site of the Auschwitz concentration camp was instigated by Jews. ${ }^{19}$

Lefebvre's followers often share this outlook. One of the four bishops ordained by him in 1988, Bernard Tissier de Mallerais, said in 1997,

The church for its part has at all times forbidden and condemned the killing of Jews, even when "their grave defects rendered them odious to the nations among which they were established." ... All this makes us think that the Jews are the most active artisans for the coming of Antichrist. ${ }^{20}$

Bishop de Mallerais, who is the authorized SSPX biographer of Lefebvre, in an interview after the Williamson controversy erupted, responded as follows to a direct question about Williamson's remarks: "I have no opinion about this.... I think that this question does not concern me, and I have no opinion on this question." 21

Nor has their record been confined simply to making statements. In 1989, Paul Touvier, a fugitive charged with ordering the execution of seven Jews in 1944 as a Nazi collaborator, was arrested in a priory of the Fraternity of St. Pius X in Nice, France. The fraternity stated at the time that Touvier had been granted asylum as "an act of charity to a homeless man." When Touvier died in 1996, a parish church operated by the fraternity offered a Requiem Mass in his honor."22

When the controversy over Williamson exploded, I immediately went to the SSPX website and captured some documents that were removed shortly afterwards. They included two postings that reflected and summed up the SSPX's position on Jews and Judaism.

In one essay, the Vatican II teaching that "the Jews should not be spoken of as rejected or accursed as if this followed from Holy Scripture" is described as "outra-

18 Thomas C. Fox, "Lefebvre movement: long, troubled history with Judaism," NCR Online, Jan. 26, 2009, available at: <http://ncronline.org/node/3180>.

19 Ibid.

20 Ibid.

21 See: <http://www.cfnews.org/Tissler-09021.htm>.

22 On Touvier and his connection to the SSPX, see his obituary in the NY Times, July 18, 1996, available at: <http://www.writing.upenn.edu/ afilreis/Holocaust/touvier-obit.html>. 
geous." ${ }^{23}$ The other essay claims that "Judaism is inimical to all nations in general, and in a special manner to Christian nations" and that "the unrepentant Jewish people are disposed by God to be a theological enemy, the status of this opposition must be universal, inevitable, and terrible." There are claims that "the Talmud, which governs Jews, orders enmity with Christians" and that the "Jewish people persecute Christendom," "conspire against the Christian State," commit "usury," and even "are known to kill Christians"! Thus, the essay defends the notion that Jews should not be "given equality of rights" but rather should be forced into ghettos ("isolated into its own neighborhoods")..$^{24}$

In their recent exposé of the SSPX and the Catholic traditionalist movement, the Southern Poverty Law Center (SPLC) cited a 1959 letter from Lefebvre's close ally, Bishop Gerald Sigaud, stating: "Money, the media, and international politics are for a large part in the hands of Jews." Bishop Sigaud also wrote: "Those who have revealed the atomic secrets of the USA were ... all Jews. The founders of communism were Jew [sic]." This letter was also posted on the SSPX website. ${ }^{25}$

Heidi Beirich, the SPLC's lead researcher on this story, noted: "And as of early February [2009], the SPLC reported that the Canadian SSPX website still hosted an archive of Williamson's anti-Semitic letters, one of which complains that 'Jews have come closer and closer to fulfilling their ... drive toward world domination.'" Other SSPX officials sound similar. After the Williamson controversy broke out, Fr. Floriano Abrahamowicz, a pastor and spokesperson for the SSPX in Northern Italy, defended Williamson and said he, too, was unsure if gas chambers were used for anything but disinfection or whether six million Jews were really murdered. He called the Jews a "people of deicide." Abrahamowicz was later expelled from the Society.

Meanwhile Rev. Arnaud Sélégny, the general secretary of the SSPX international headquarters in Menzingen, Switzerland, is on record saying that Williamson would certainly be included in any reconciliation between SSPX and the Vatican because "everybody is allowed to have his opinion in the Society." 26

These positions are not original to the SSPX, nor are they a theological innovation to current Catholic traditionalists; indeed, they bear a striking similarity to the writings of an otherwise obscure Irish priest named Father Denis Fahey, whose work is one of the most - if not the most - frequently cited by the members of the SSPX and similar believers. Mary Christine Athans, in her important book, The Coughlin-Fahey Connection: Father Charles E. Coughlin, Father Denis Fahey, C.S. Sp., and Religious Anti-Semitism in the United States, 1938-1954, thoroughly explored Fahey's life and thought and how his theology of antisemitism made its way from Ireland to the United States. ${ }^{27}$

23 Can it truly be said that the Jewish race is guilty of the sin of deicide, and that it is consequently cursed by God, as depicted in Gibson's movie on the Passion? Featured in the Q\&A section, March 2004.

24 Frs. Michael Crowley and Kenneth Novak, "Of the Jewish People in History." Originally printed in the April 1997 issue of The Angelus magazine.

25 Intelligence Report, Winter 2007. A copy of this letter is in the author's possession.

26 Heidi Beirich, "Behind the Bishop: The Anti-Semitism of the SSPX," Hatewatch, Feb. 26, 2009, available at: <http://www.splcenter.org/blog/2009/02/26/behind-the-bishop-the-anti-semitism-ofthe-sspx>.

27 Mary Christine Athans, The Coughlin-Fahey Connection: Father Charles E. Coughlin, Father Denis Fahey, C.S. Sp., and Religious Anti-Semitism in the United States, 1938-1954 (New York, 1991). 
Fahey was born on July 2, 1883 in Kilmore, Golden, County Tipperary, Ireland. In 1900, he was a novice of the Holy Ghost Congregation in France, which was still dealing with the impact of the Dreyfus Affair and the French government's anti-clerical actions, particularly the Associations Laws of 1905 that required religious congregations to be recognized by the government. At that time, France was an incubator of ecclesiastical antisemitism. As David Kertzer wrote: "In the cauldron of Catholic resentment toward the republican state in the 1880s, the Jews, visible in national politics, in the civil service and in the economy, served as a lightning rod, all that was wrong with modern French society." 28 This was a struggle that began, according to those Catholics, with the French Revolution, which one such writer described as "[t]he greatest event of history for over 1800 years." 29

In 1908, Fahey went to Rome, where he obtained two doctorates (philosophy and theology) and lived at the Collège Français (Pontifical French Seminary). ${ }^{30}$ Ordained in 1911, Fahey returned to Dublin in 1912, where he stayed (except for 1916-1920, when he was in Switzerland for health reasons) as professor at the Holy Ghost Seminary until death on January 24, 1954. Fahey was fairly prominent in Ireland, maintaining a high profile as a public intellectual, as evidenced by the fact that, upon his death, Irish Prime Minister Eamon de Valera attended his evening funeral Mass. ${ }^{31}$ Mervyn O'Donnell, in his research on Jewish immigration to Ireland in 1933-1939, has pointed out that during this period "[m]any Irish civil servants betrayed negative preconceived notions about the Jews." ${ }^{2}$ While de Valera was generally seen as being relatively moderate toward Jews at that time, and thus his attendance at the Mass might have been a matter of protocol, it certainly reflected on Fahey's stature at the time of his death.

While in Rome, Fahey was heavily influenced by Father Henri Le Floch, who was the Superior of the Collège Français. Athans described Le Floch

as an exponent of conservative right-wing French and Italian Catholic thought in those anti-Modernist years ... Le Floch had substantial influence on Fahey. ... He was later removed from his position as Rector because of his relationship to the controversial and anti-Semitic Action Française movement which was finally condemned by Pius XI in $1926 .{ }^{33}$

Le Floch was also a revered mentor to Lefebvre. Athans, who interviewed a number of Fahey's students and younger colleagues in Ireland, wrote that "[s]ome [priests] believe that Le Floch's influence can also be traced to Archbishop Marcel Lefebvre ... founder of the dissident traditionalist movement ... known as the Fraternity of SPX." ${ }^{34}$ Another resident of the French Seminary was the future Archbishop of Dublin and Primate of

28 David Kertzer, The Popes Against the Jews (New York, 2001) p. 170.

29 Vicomte Leon de Poncins, Freemasonry and Judaism (New York, 1994) p. 29. This book, originally published in 1929, is now released by what is apparently a black-oriented publishing house.

30 Mary Christine Athans, "A New Perspective on Father Charles E. Coughlin," in Church History, Vol. 56, No. 2 (1987) p. 226.

31 Athans, Coughlin-Fahey, p. 59.

32 Mervyn O'Donnell, “The 'Jewish Question,' Irish Refugee Policy and Charles Bewley, 19331939," in Guðmundur Hálfdanarson (ed.), Racial discrimination and ethnicity in European history (Pisa, 2003) p. 148.

33 Athans, Coughlin-Fahey, pp. 22-23.

34 Ibid., pp. 62-63, n. 25; cf. Yves Congar, Challenge to the Church: The Case of Archbishop Marcel Lefebvre (1977) pp. 16, 88-90; see also: <http://www.catholicity.com/ commentary/rutler/07849.html>. 
Ireland John Charles McQuaid, who studied under Fahey. McQuaid's biographer, John Cooney, has asserted that Le Floch's "combination of theological rigidity and political conservatism rubbed off on the seminarians, among them ... Marcel Lefebvre. ${ }^{\prime 35}$ Having been nurtured in the same intellectual milieu, it is no surprise that Fahey and Lefebvre shared much of the same weltanschauung.

Among other sources, Fahey also drew on the Revue International des Sociétés Secrètes. ${ }^{36}$ This journal was founded in 1912 by Father Ernest Jouin, who was described by Kertzer as "[t]he main champion of the Protocols of the Elders of Zion, and the best known exponent of Catholic antisemitism in the 1920s" in France. ${ }^{37}$ Jouin and his work were not isolated on the fringes of Catholic life. Pope Benedict XV gave Jouin the title of "Prelate of His Holiness', which he used to add papal authority to his works, and he received further blessings from Vatican Secretary of State Gasparri in 1919 and later from Pope Pius XI as well. Jouin even claimed credit for originating the term "Judeomasonic" in 1920 and claimed to have been told by Pius XI to "[c]ontinue your Review ... for you are combating our mortal enemy." 38 Fahey was not the only one influenced by Jouin; the influential Italian fascist Roberto Farinacci in 1939 repeated some of these familiar themes in urging harsher anti-Jewish measures in Italy, claiming that the French Revolution had created a great wrong by proclaiming rights of men that grew into rights of Jews and that this situation required remedying by following the paths laid out by the Jesuits over the years in La Civilta Cattolica and by Jouin with his papal approved Review and publication of the Protocols. ${ }^{39}$

Fahey was a prolific writer, publishing a series of books and pamphlets, many with repetitive titles and similar themes, including:

- The Mystical Body of Christ in the Modern World (Dublin: Browne and Nolan, 1935).

- The Mystical Body of Christ and the Reorganization of Society (Waterford, Ireland: Browne and Nolan, 1939).

- The Rulers of Russia, 3d American edition, revised and enlarged (Detroit: Condon Print. Co., 1940).

- The Kingdom of Christ and Organized Naturalism (Wexford, Ireland: Forum Press, 1943).

- Grand Orient Freemasonry Unmasked as the Secret Power Behind Communism (1950, (republication of George F. Dillon's work with a foreword by Fahey).

- Humanum Genus: Encyclical Letter of His Holiness Pope Leo XIII on Freemasonry (London: Britons Publishing Society, 1953).

- The Kingship of Christ and the Conversion of the Jewish Nation (Dublin: Holy Ghost Missionary College, 1953).

For Fahey, the world was a very simple but dangerous place. In his Manichaean perspective, he believed that God was only accessible through the Catholic Church, which in turn was "supra-national and supernatural." However, God was locked in a cosmic struggle with Satan, who was, for Fahey, a very real antagonist. Although Judaism was

35 John Cooney, John Charles McQuaid: Ruler of Catholic Ireland (Dublin, 1999) p. 53.

36 Ibid., p. 129.

37 Kertzer, The Popes Against the Jews, p. 267.

38 Ibid., pp. 267-269.

39 Ibid., pp. 283-284. Farinacci was described by Susan Zuccotti "as one of the countries most vocal Jew baiters," in Zuccotti, The Italians and the Holocaust (New York, 1987) p. 49. 
the chief antagonist, Satan's agents in this world included "Bolshevism, as the most recent development in the age-long struggle waged by the Jewish nation against the Supernational Messias, our Lord Jesus Christ, and his Mystical Body, the Catholic Church." Fahey followed that depiction with a comparison of Catholicism and Judaism that was totally to the detriment of the latter. According to his theology, by its rejection of Jesus as Christ, Judaism attempts to "recast [the world] in the mould of Jewish national life." Fahey concluded by asserting that this rejection "cannot but mean the complete undoing of the Catholic organization of society," which was, in Fahey's view, the appropriate order of things. ${ }^{40}$

As mentioned above, Fahey regarded Communism as just a tool used by the Jews. "The real forces behind Bolshevism in Russia are Jewish forces, and that Bolshevism is really an instrument in the hands of the Jews for the establishment of their future Messianic kingdom." 41

Fahey's contrast between Judaism and Catholicism had different implications, some of which transcended pure theological concerns. For example, in his above-mentioned tract The Rulers of Russia, Fahey spells out the differences between Jews and Catholics regarding what he terms "citizenship":

Here it will be well ... to contrast the Jewish idea of citizenship with the Catholic idea. ... As members of their own "messianic" nation, they must strive for the domination of their nation over others, as thus they alone, they hold, justice and peace can be achieved on earth. The Jew would fail in his duty to the Messias to come if he did not subordinate the interests of other nations to is own. ... But the Catholic Church, being supra-national and supernatural, does not aim at the obliteration of national characteristics and qualities by the imposition of a national form, but at their harmonious development by the elimination of the defects due to original $\sin { }^{42}$

This reading of theological history viewed Judaism as a religion committed to ruling over the other nations and its adherents as not possessing the qualities of eligibility for equal citizenship, while Catholicism by its nature (and despite the historical evidence to the contrary) is seen as less restrictive and the proper dominant authority in society.

Fahey further believed that the world had reached its peak in the 13th century, when the Church was its essential ruler (at least in Europe, which appeared to be all that mattered for Fahey). However, that state did not last long. For Fahey, there was no concept of religious liberty; in fact, it was a tool of the devil that was used to take the state and society away from the true worship of the Church. An echo of this belief can also be found in Williamson's thought. In comments on Pope Benedict's Address to the Curia of December 2005, Williamson stated:

What is wrong with freeing States from any obligation to Christ the King is that implicitly you are denying that Jesus Christ is God. ... Religious liberty means in effect, a declaration of independence from God, which is directly opposed to the first Commandment. ... However, where Catholics are in a sufficient majority, the State may physically prevent the public practice of false religion while tolerating their practice in private. ${ }^{43}$

40 Fahey, Rulers of Russia (Detroit, 1940) pp. 44-45.

41 Ibid., p. 22.

42 Ibid., p. 72.

43 See: <http://www.cfnews.org/bw-dec22.htm>. 
This was a fundamental tenet of Lefebvre's belief as well. In his biography by de Mallerais, he is quoted as saying that the acceptance of the doctrine of religious liberty is "a scandal to Catholic souls (that) cannot be measured. The Church is shaken to its very foundation." 44

In January 2008, a SSPX theologian repeated this theme in a Catechism of the Crisis of the Church addressed to the Church membership. After posing the question "Is there, then, no right to the free exercise of religion?" he offered the following answer:

The true religion possesses the absolute right to develop and to be practiced freely, for no one can be impeded from serving God in the way He Himself has prescribed. It is an exigency of the natural law. The false religions, to the contrary, have no real right to be practiced precisely because they are false and erroneous. Error can never have any right; only the truth has rights. ${ }^{45}$

The same Catechism succinctly summed up the SSPX's stance on tolerance; tolerance, it claimed, was simply "the patient endurance of an evil." 46

For Fahey and similar thinkers, political freedom, not only religious freedom, can only be found in, and thus only given by, the Church, and so the right order is one in which the Church reigns supreme and delegates those freedoms as it desires and for its benefit only. Outside of the Church, there are no rights and no freedom, and all in opposition or in non-belief are agents of Satan.

Fahey's traced it all back to the original fall of humanity in the Garden of Eden, which was then followed by more recent tragic historical events, such as the Reformation and the French Revolution, with equally disastrous results. As he wrote,

[the] Protestant Reformation ... broke the unity of European subjection to the supranational, supernatural Church of Christ. ... It did not however install a naturalistic international organization. ... That was reserved for the French Revolution [which began] the domination of the world by Masonic Naturalism. ... Behind Masonry, however, [was] the other naturalistic force of the once chosen people. ... The Jews everywhere made use of Freemasonry to secure the rights of becoming citizens of the once Christian states. ${ }^{47}$

Even the horrors of the Holocaust did not shatter Fahey's deep-rooted antisemitism. He did find it necessary after the Holocaust to attempt to draw a distinction between unacceptable antisemitism, which was defined as "hatred of the Jewish nation" and "opposition to the Jewish and Masonic naturalism," which he endorsed as a vital aspect of Catholicism. ${ }^{48}$ For Fahey, naturalism was a source of evil precisely because it inevitably led to rejection of belief in God or any other form of supernaturalism. The revulsion felt

44 Quoted in Rome-SSPX, "Background to the Doctrinal Discussions," available at: <http://cf news.org?SSPX-DD.htm> (which is a traditionalist website).

45 Fr. Matthias Gaudron, "Catechism of the Crisis in the Church," The Angelus, Vol. XXXl, No. 1 (January 2008) p. 16.

46 Ibid.

47 Fahey, Rulers, pp. 50-51.

48 Fahey, What Really is Anti-Semitism?, available at: <http://www.salvationisfromthejews.com/ sspx_what_really_is_anti_semitism.html $>$. The description that he quoted approvingly was taken from a review of his book The Kingship of Christ and the Conversion of the Jewish Nation, published in La Civilta Cattolica (March 1947). 
by the world to the horrors of the Holocaust created the necessity for Fahey to try and distinguish his brand of antisemitism from that of the Third Reich. In the foreword to his 1953 book The Kingship of Christ and the Conversion of the Jewish Nation (the body of the book was written before the war but published afterwards) he wrote of

... the confusion created in minds owing to the use of the term "Anti-Semitism." The Hitlerite naturalistic or anti-supernatural regime in Germany gave to the world the odious spectacle of a display of Anti-Semitism, that is hatred of the Jewish Nation. Yet all the propaganda about that display of Anti-Semitism should not have made Catholics forget the existence of age-long Jewish Naturalism and Anti-Supernaturalism. Forgetfulness of the disorder of Jewish naturalistic opposition to Christ the King is keeping Catholics blind to the danger that is arising from the clever extension of the term "Anti-Semitism" with all its war connotation to the mind of the unthinking. ${ }^{49}$

In the body of this book, Fahey went so far as to justify the Nazi actions against the Jews on theological grounds and to imply that the Catholic Church was even more of a victim. In Fahey's words:

One can readily conclude that the National-Socialist reaction against the corroding influence of Jewish Naturalism on German national life leads not only to measures of repression against the Jews but to a dire persecution of the Catholic Church. The deified German race has attacked the rival natural deity, the Jewish race, directly, and has proceeded systematically to get rid of it as corrupting the very fount of deity, German blood. ${ }^{50}$

In other words, the Nazis were only reacting to the Jewish threat, and their major fault was not in the reaction, but rather the form it took. In the same work, Fahey spelled this out in even greater detail: "We have seen that the Nazi movement in Germany is one of a number of national reactions against the naturalistic Internationalism of the Jewish Nation and of Freemasonry." 51 Thus, in Fahey's vision of the Third Reich, the innate Jewish "naturalism" was something that was recognized by many as a danger that would naturally lead to defensive reactions, but it was the Church that was the ultimate opponent and the ultimate victim of the Nazis. ${ }^{52}$

Fahey, like most conspiratorial antisemites, relied uncritically on highly questionable sources for his information. He used the most rabid of antisemites as reliable sources, for example citing Arnold Leese (in The Fascist, May 1939): “Jews are the chief owners of urban real estate in Poland." ${ }^{53}$ Leese was one of the most well-known and radical antisemitic figures in England during that period. Among his writings was a work that claimed that the blood libel was real. He also served a number of prison sentences connected to his activities, which included aiding Waffen-SS POWs in escaping from England. Fahey also drew upon the classic antisemitic work The Protocols of the Elders of Zion. Athans has compared Fahey's attitude to the Protocols to that of Henry Ford,

49 Fahey, The Kingship of Christ and the Conversion of the Jewish Nation, pp. 5-6.

50 Ibid., pp. 44-45.

51 Ibid., p. 57.

52 For a convincing review of the Nazis' overwhelming obsession with and reliance on antisemitism as a driving force for World War II and the Holocaust, see Jeffrey Herf, The Jewish Enemy (Cambridge, 2006).

53 Fahey, Rulers of Russia, p. 70, n. 1. 
Charles Coughlin, and Nesta Webster (all antisemitic figures who Fahey admired), who "all admitted that [while] they could not prove the veracity of the Protocols ... what was described in the Protocols was what was going on in the world." Increasingly Fahey relied on the Protocols in his own work. ${ }^{54}$

And again, like many other conspiratorial antisemites, Fahey was prone to seeing conspiracies of Jews everywhere. In one of his books, he even claimed that Jews were attempting to eliminate from the celebration of Christmas any the religious meaning. The proof for this insidious plot was:

Christmas cards that show a row of dogs and a few birds have nothing to remind the recipient of what the rejoicing is for.... In this process of eliminating the supernatural Messias from the celebration of the anniversary of his birth, the largest firm of Christmas card manufacturers, have certainly played a great part. ... All three directors appear in the communal Directory of the Jewish Year Book (and other Jewish communal activities). ${ }^{55}$

Thus, the Jews, through the ownership of a greeting card company by three Jews, were intent on stripping Christmas of its sacral meaning!

In other works, he published lists of Jews in the Russian/Communist leadership, as well as a list of "Members of the Jewish Nations in the United Nations Organization. ... As of last year [1951] this tiny but powerful group of Zionist nationalists hold the following key posts." This list comprised 86 names, spread over five pages. ${ }^{56} \mathrm{~A}$ forerunner of many extremists today, Fahey wrote that "[t]he real purpose of the UN is to pave the way for a 'World Government' to which all nations surrender their sovereignty and independence." 57

For Fahey, this threat from Jews meant that the Church had to fight back by all available means, including depriving Jews of their civil rights, thus denying them the latitude and freedom they were using to undermine society. He believed that

[a] step to be taken to undo the naturalism of the French Revolution and, at the same time, prevent onslaughts on the Jews, is to withdraw citizenship of other States from all of them, and limit them to citizenship of some other State, their own. That State must not be Palestine, for the Jewish claim to Palestine is implicitly a denial that they have disobeyed God and missed their vocation by the rejection of the True Supernatural Messias. ${ }^{58}$

Finally, after the Holocaust, he was worried that Catholic sympathy for Jews because of their terrible suffering would create a lessening of Catholic anti-Jewish vigilance. And, despite the growing awareness of the Nazi Holocaust, those crimes did not begin to compare to the ancient Jewish crime of deicide, which should have ordained history and the structure of society ever since: "Some Catholics seem to forget that the Jews who, in their terrible opposition to God ... were intent on the most awful crime ever committed, the crime of deicide." 59

54 Athans. Coughlin-Fahey, p. 103.

55 Fahey, The Kingship of Christ and the Conversion of the Jewish Nation, p. 51.

56 Ibid, pp. 169-173.

57 Ibid., p. 174.

58 Fahey, Rulers, p. 75.

59 Fahey, The Kingship of Christ and the Conversion of the Jewish Nation, p. 53. 
Mark Lilla has described how "[t]he Catholic Church in particular cast itself as spokesman for reaction throughout much of the [19th] century." ${ }^{\prime 20}$ Fahey's theology was clearly formed in and reflective of that Church. However, his teachings might well have faded into obscurity, but for the fact that he found a powerful ally in the United States in the person of Father Charles Coughlin who brought Fahey to the attention of a receptive audience across the Atlantic.

In her book on The Coughlin-Fahey Connection and in other writings, Athans has demonstrated how "the 'theologian' Coughlin quoted most frequently was an Irish priest, Father Denis Fahey." ${ }^{11}$ Coughlin did not just quote Fahey or even base his thought on the Irish priest's writings but took an even more active role, especially by reprinting and distributing Fahey's tract The Rulers of Russia through his Social Justice Publishing Company in 1940, when Coughlin was at the height of his powers. This distribution ensured Fahey's introduction to a mass American audience.

Coughlin was easily the most prominent Catholic and antisemite in the United States at that time. As one of his biographers wrote: "Coughlin ... dominated among antisemitic public figures in these years." 62 His domination was reflected in his reach. "Not only did he reach millions with his weekly radio broadcasts, but he also disseminated his extremist messages through his widely read magazine Social Justice, which claimed 200,000 subscribers." 63 The result was that he popularized an antisemitism that had a significant impact on US popular discourse and even translated into the spurring of antisemitic acts that were often led by his followers and threatened public safety. ${ }^{64}$

As Athans has clearly demonstrated, by bringing Fahey's writings to an American audience, Coughlin allowed Fahey to become a bridge between the French and papal reactionary Catholic antisemitism of the early 20th century and extreme right-wing groups and figures in America. ${ }^{65}$

Another scholar described it as translating "the struggles of the Christ and Antichrist into contemporary terms, in which Christianity and America represented Christ, and Communists and bankers represented the Antichrist. And conveniently, the two evils were linked together in the Jewish race." And, while a number of the hierarchy were displeased with Coughlin's ravings, he nevertheless found a receptive and supportive audience in the diocesan press. One of his key supporters in the eastern United States was the Brooklyn Tablet. In a typical defense of Coughlin's antisemitism, the editor (Patrick Scanlon) remarked:

Fr. Coughlin has fearlessly and courageously discussed the Jewish problem that others would pass by in cowardly silence.... [No Catholic can honestly criticize] Fr. Coughlin's very temperate reference to the part that a Jewish Weltanschauung contributed to the untoward world conditions. ${ }^{66}$

60 Mark Lilla, The Stillborn God (New York, 2008) p. 222.

61 Athans, Coughlin-Fahey, p. 224.

62 Donald Warren, Radio Priest: Charles Coughlin, the Father of Hate Radio (NY, 1996) pp. 188-189, 305, cited in Joseph W. Bendersky, "Dissension in the Face of the Holocaust: The 1941 American Debate over Antisemitism," in Holocaust and Genocide Studies, Vol. 24, No. 1 (Spring 2010) p. 96.

63 Ibid.

64 See, among many others, David Bennett The Party of Fear (New York, 1995) pp. 263-266.

65 Athans, Coughlin-Fahey.

66 Brooklyn Tablet, Feb. 4, 1939, cited in Esther Feldblum, The American Catholic Press and the Jewish State 1917-1959 (New York, 1997) p. 46. 
What Scanlon called a "temperate reference" was translated by some of Coughlin's followers into the formation of a radical group called the Christian Front, whose members were implicated in a series of disruptive and violent antisemitic acts that in the late 1930s and early 1940s disturbed the peace and threatened the security of Jews in cities with a large Irish Catholic presence such as Boston and New York. In both cities, the wave of antisemitism was often ignored by sympathetic Catholic police and eventually had to be countered through official action by Massachusetts Governor Leverett Saltonstall and New York Mayor Fiorello LaGuardia. ${ }^{67}$

Even before the wave of antisemitism became overt, the antisemitic discourse had become sufficiently heated and the issue sufficiently politically sensitive that it even reached the White House. In a 1941 memorandum to Myron Taylor, his personal representative to the Vatican, President Franklin D. Roosevelt wrote:

I forgot to mention that when you get the chance, you might express the thought that there is a great deal of anti-Jewish feeling in the dioceses of Brooklyn, Baltimore and Detroit and this feeling is said to be encouraged by the church. The point to make is that if anti-Jewish feeling is stirred up, it automatically stirs up anti-Catholic feeling and that makes a general mess. ${ }^{68}$

Taylor did raised the issue but found the Vatican essentially non-responsive. It was the Vatican's resident American expert, Father Joseph Patrick Hurley, who himself was a virulent antisemite and who advised the Vatican to ignore Coughlin's antisemitism. ${ }^{69}$

While the Coughlin-Fahey correspondence continued in the same vein even after Coughlin's official silencing, the loss of Coughlin's public platform certainly contributed to the lowering of Fahey's profile in the United States. ${ }^{70}$

However, the damage had been done, and Fahey's influence had become entrenched in certain circles. While for the most part scholars have traced Fahey's influence in the extremist Catholic circles that they have been examining, it is entirely possible that his connection with Coughlin allowed his influence to spread even wider. Among Coughlin's associates and allies were Gerald Winrod and Gerald L.K. Smith, who were foundational figures in American right-wing extremism. Smith was also in direct contact with Fahey, exchanging letters in late 1940s and early 1950s. Fahey wrote in at letter to Irish follower that

67 Leonard Dinnerstein, Antisemitism in America (New York, 1995) pp. 120-123, 132-133. Philip Jenkins, Hoods and Shirts: The Extreme Right in Pennsylvania 1925-1950 (Chapel Hill, 1997) examines the Christian Front and similar groups in one state.

68 FDR Archives, President's Secretary's File, 1941, Box 51.

69 Charles R. Gallagher, Vatican Secret Diplomacy: Joseph P Hurley and Pope Pius XII (New Haven, 2008) pp. 68-70; see also Gallagher's article "A Peculiar Brand of Patriotism: The Holy See, FDR, and the Case of Reverend Charles E. Coughlin," in David B. Woolner and Richard G. Kurial, FDR, the Vatican, and the Roman Catholic Church in America, 1933-1945 (New York, 2003) pp. 272-275. Gallagher also points out that Hurley "became the only bishop of the entire Second Vatican Council to officially and publicly protest the signing of Nostra Aetate."

70 For example, see Coughlin's letter to Fahey: "while anti-Semitism is to abhorred in so far as it is related to hatred for the Jews as individuals and racials, nevertheless, anti-Judaism, which means opposition to the Judaic concept of life, is not to be so condemned. ... I cannot understand how so many amongst our hierarchy and clergy are demonstrating tolerance towards Judaism," letter from Coughlin to Fahey, Mar. 5, 1941, quoted in Athans, New Perspectives, pp. 188-189. 
the programme of Gerald L.K. Smith as taken from his paper The Cross and the Flag ... declares unflinchingly and unequivocally for the Rights of Christ the King. Are his detractors and smearers for Christ the King or against Him? The Judaeo-Communists tried to brand every man who stood for American nationalism and against Communism during the war as pro-Nazis. ${ }^{71}$

Another such figure, Francis Parker Yockey, published an article in Coughlin's Social Justice magazine in 1938. The Catholic born Yockey was a fervent admirer of Adolf Hitler, who attempted, especially in his almost incomprehensible book Imperium, to find a way to adapt Nazism to the post-World War II world. In his early Social Justice article, Yockey lamented that an "alien" control of the media resulted in the spiritual enslavement of American youth. ${ }^{72}$ The historian George Michael has also noted Coughlin's influence on Willis Carto, arguably the most important figure on the American far right in the last half-century. Carto has founded and financed a number of major far-right initiatives over the last 50 years, including the Liberty Lobby and its newspaper Spotlight, the Institute for Historical Review (the center for Holocaust denial), The Barnes Review, and the Populist Party (which ran the notorious neo-Nazi David Duke as its 1988 presidential candidate). Carto recalls Coughlin as a seminal figure from his childhood. ${ }^{73}$

As a youth Carto claims to have never heard of right-wing extremists, "with the exception of Father Coughlin, to whose broadcasts he would listen with the whole family." ${ }^{\prime 4}$ Carto "recalled listening to Coughlin's broadcasts with his family and described him as a spellbinding orator." ${ }^{\text {" }} \mathrm{He}$ also characterized "Coughlin as a genuine populist" and cited "opposition from Jewish organizations ... as evidence of Coughlin's bona fides as a true American hero." 76

Carto was also influenced by Yockey, whom he visited in jail just before Yockey's suicide. As Michael writes: "Yockey left quite an impression on Carto; as he once remarked, 'I knew I was in the presence of a great force. '"77

This nexus between the extremist traditionalist Catholics and the far right has continued to the present. Richard Williamson has also found himself taken up by a various aspects of the movement. Among those who have adopted the bishop are the notorious neo-Nazi and professional Holocaust denier Mark Weber, the director of the Institute for Historical Review, who in a March 2009 article entitled "Bishop Williamson and 'Holocaust Denial': Why the Uproar?" concluded that "[t]he Williamson affair underscores a well entrenched Jewish-Zionist bias in the cultural life of modern Western society, and reminds us, once again, of the power behind that bias." 78

Robert Faurisson, the French academic Holocaust denier, who is currently in the middle of a squabble with Weber over the future of Holocaust denial, also sprang to Williamson's defense. According to a posting on his blog:

71 Fahey, letter of May 3, 1949, quoted in Athans, New Perspectives, p. 213.

72 On Yockey, see George Michael, Willis Carto and the American Far Right (Gainesville, 2008) pp. 75-86.

73 Ibid.

74 Ibid., p. 20.

75 Ibid., p. 10.

76 Ibid., p. 154.

77 Ibid., p. 74.

78 See: <http://www.ihr.org/williamson_march09.html>. 
The height of his enemies' misfortune, and for the traditionalist Catholic he is ... if he ever did fall to his knees before the new Inquisition he would immediately remind everyone of Galileo, the man whom science and history ended up acknowledging to be right despite his abjuration. Even if he wound up losing, Richard Williamson would thus have won. ${ }^{79}$

The links between the Holocaust deniers and Catholic extremists are not limited to Williamson. In 1993, the Journal of Historical Review, the house organ of the Institute of Historical Review, the central organization of Holocaust deniers in the United States, published in its September/October issue three short entries under the title "The Holocaust Issue: Three Christian Views." Two were by traditionalist Catholics (including the late Joseph Sobran, fired by William Buckley from his journal National Review for antisemitism) and the other was by Bishop Louis Vezelis, described as the "editor of The Seraph, a traditionalist Catholic monthly." According to Vezelis, "the preponderance of objective and factual evidence shows the promoters of the Holocaust story to be libelous frauds." ${ }^{80}$ Sobran was defended by the Institute of Historical Review as far back as 1987 and later spoke at its 2002 conference. ${ }^{81}$

Despite the denunciations of Williamson's Holocaust denial, and even some pro forma condemnations of antisemitism from the SSPX, there can be no question, based on their own writings, that the antisemitic teachings espoused by Fahey and repeated by Williamson still permeate the heart of the theology of the SSPX and many similar Catholic traditionalists.

For example, still available on the Asia SSPX's website is an article from March-April 2000 by Bishop Salvador L. Lazo, entitled: "My Return of the Traditional Latin Mass: Autobiography of a Traditional Catholic Bishop." In this article, Lazo lists some of the books that inspired him on his spiritual journey. They include Fahey's The Kingship of Christ and The Conversion of the Jewish Nation, as well as others about the dangers of Freemasonry. Lazo was very open about their impact on his thought, writing that

Reading these books gave me a better idea of the crisis and confusion in the Church today. It became clear to me who are the real enemies of the Catholic Church. Father Denis Fahey pinpointed them when he wrote: "The enemies of the Catholic Church are three. One invisible, Satan, and two visible: a) Talmudic Judaism, and b) Freemasonry." ... That Judaism is the visible chief enemy of the Catholic Church, is evident from the Church history, from words and deeds of individuals, and groups and the teachings of the Talmud of which the Kabbalah constitute the basis of Judaism. ${ }^{82}$

Williamson has openly held up Fahey as an authority to be relied upon. On the website of the SSPX's US seminary (based in Winona, Minnesota), I recently found a letter

79 See: <http://robertfaurissonblogspot.com/2009/04/mark-weber-must-resign-from-institute. html>.

80 Loius Vezelis, "Examine All the Evidence," in Journal of Historical Review, Vol. 13, No. 5 (September/October, 1993) pp. 34-35. Buckley's opinion of Sobran's antisemitism can be found in William Buckley, In Search of Anti-Semitism (New York, 1992). His conclusion (pp. 118-119) was that Sobran had indeed "written anti-semitic articles."

81 Mark Weber, Joseph Sobran and Historical Revisionism, available at: <http://www.ihr.org/jhr/ v07/v07p373_Weber.html>; and Sobran, For Fear of the Jews, available at: <http://www.ihr.org/ conference/14thconf/sobranconf.html $>$.

82 See: <http://www.sspxasia.com/Newsletters/2000/March-April/Autobiography.htm>. 
written by Williamson in 1983, before he was even ordained as a bishop, in which, in relation to a book written by a Protestant author, he advised his readers that "Catholics should be very wary of this kind of book. Let them keep to sound doctrine and proven authors, for instance the excellent Fr. Denis Fahey." 83

Finally, it must be recognized that Fahey's baleful influence is alive today not only in the SSPX but also in similar-minded groups, as reflected in the following quote. It is from John Sharpe, the former Naval Academy graduate and officer and rabid traditionalist Catholic. Sharpe sued a local paper that had publicized his antisemitic beliefs for libel. In the decision against him, the judge wrote: "No reasonable person can read Sharpe's individual writings and conclude that he espouses anything other than a deep, abiding and pervasive suspicion of and hostility toward Jews, whether considered as a collective people, religion, nation or ethnic group." 84

Sharpe, who has his own traditionalist distribution house, concluded a 2003 article that he published in the SSPX's magazine The Angelus criticizing the 2001 Vatican document The Jewish People and Their Sacred Scriptures in the Christian Bible with a quote from Fahey's Mystical Body of Christ and the Reorganization of Society, in which he hoped that "we all then have the courage to respond with the words of Fr. Fahey: 'In that sense, every sane thinker must be an anti-Semite."'85

The SSPX has been quite open about its goals. Speaking about the current efforts by Rome to bring the group back into the Church, Bishop Tissier de Mallerais was blunt, saying that "we do not change our positions, but we have the intention of converting Rome, that is to lead Rome towards our positions." 86

Any attempt by the Vatican to bring these groups out of schism and into the Church must honestly confront these issues and not ignore or hide them. If baptism was once, for Jews, the ticket to admission to Western society, then acceptance of Vatican II, including the rejection of Catholic antisemitism and the acceptance of religious liberty, must be the price of admission for these groups into today's Church. Pope Benedict has spoken movingly and powerfully about his feelings about antisemitism, the Holocaust, Jews, and Judaism. Yet unless the Church's current deeds match its words, JewishCatholic relations will continue their downward trajectory of recent years.

83 See: <http://www.sspxseminary.org/publications/rectors-letters-separator/rectors-letter/64. html>.

${ }^{84}$ See: $<$ http://www.icourt.info/Opinions/judge/Thomas/Sharpe-v-Landmark-Opinion.pdf $>$.

85 John Sharpe, Judaism and the Vatican, available at: <http://webarchive.org/web/20031012011 638/http://www.sspx.ca/Angelus/2003_June/Judaism.html>.

86 See: <http://rorate-caeli.blogspot.com/2009/02/tissier-de-mallerais-speaks.html>. 



\title{
Post-war Antisemitism: Germany's Foreign Policy Toward Egypt
}

\author{
Ulricke Becker*
}

\section{INTRODUCTION}

After 1948, every country that was diplomatically involved in the Middle East conflict was confronted with Arab hostility toward Israel and was therefore challenged with the task of reacting to such animosity. A new antisemitism emerged that was directed against the very existence of a Jewish state. This gives rise to several important questions. How did diplomats react to Arab animosity toward Israel? Did Arab antisemitism play a role in the conceptions of foreign policy? If so, was this topic actually brought up with Arab states? Did diplomats do anything to confront this problem? ${ }^{1}$

While these questions emerged for all diplomats, German diplomats had to address more specific concerns. Especially in Egypt, they were confronted with the ramifications of German antisemitic propaganda and politics, which many of them had personally designed and promoted only a few years earlier. The Middle East policy of the Nazis had been anti-British in design and antisemitic in essence. Especially during the second half of World War II, Germany had employed considerable efforts to incite Arabs to fight against Germany's enemies via radio propaganda with a distinctly antisemitic, anti-British, and anti-American character, as Jeffrey Herf convincingly describes in his illuminating book on this subject. ${ }^{2}$ The Mufti of Jerusalem, Hajj Amin el-Husseini, was a close ally of the Nazis and had played a major role in programming propaganda broadcasts into the Arab World. ${ }^{3}$ In the post-war years, the Mufti-although he had been

* Doctoral scholar, University of Stuttgart; former Graduate Fellow, YIISA, Yale University.

1 For the sake of clarity, Arab hostility toward Israel is not necessarily antisemitic. However, there is a point when political enmity opposing Zionism crosses over into antisemitism, for example when there is a positive reference to Nazi antisemitism or when the acceptance and dissemination of conspiracy theories like the "Protocols of the Elders of Zion" is involved. Holocaust denial is also an important aspect of this new antisemitism.

2 Jeffrey Herf, Nazi Propaganda for the Arab World, New Haven and London, 2009. See also Matthias Küntzel, "Nationalsozialismus und Antisemitismus in der arabischen Welt," in Doron Rabinovici, Ulrich Speck and Natan Sznaider (eds.), Neuer Antisemitismus? Eine globale Debatte, Frankfurt am Main, 2004.

3 Cf., e.g., Klaus Gensicke, Der Mufti von Jerusalem und die Nationalsozialisten. Eine politische Biographie Amin el-Husseinis, Darmstadt, 2007; Josef Boris Schechtmann, The Mufti and the Fuehrer. The Rise and Fall of Haj Amin el-Husseini, New York, 1965; Zvi Elpeleg, The Grand Mufti: Haj Amin alHussaini, Founder of the Palestinian National Movement, Shmuel Himelstein (ed.), London, 1993; Matthias Küntzel, Jihad and Jew-Hatred. Islamism, Nazism and the Roots of 9/11, New York, 2007. 
involved in war crimes - was a figure of considerable political influence in Egypt, and his Nazi-like antisemitism affected the Palestinian national movement and the Muslim brotherhood in Egypt. Then there was the circle of young officers including Abdel Nasser and Anwar as-Sadat. In July 1952, they seized power in Egypt in a military coup d'état. During World War II, both of them had collaborated with the Germans as guerrilla fighters. ${ }^{4}$ As politicians, Nasser and Sadat both recommended the "Protocols of the Elders of Zion" as an important source of information on the nature of Israel and the Jewish people. Nasser's brother Sauqi Abdannasir personally edited an Arabic translation of the "Protocols," and under Nasser's presidency in the 1950s one of the most radical antisemitic publicists of the Third Reich, Johann von Leers, who had been an open advocate of Jewish genocide, was employed in the Egyptian propaganda ministry. He was in charge of propaganda against Israel and organized lectures for Egyptian officials. ${ }^{5}$ Bernard Lewis is one of many historians who have pointed out how German National Socialism was openly praised in post-war Egypt. This was the political climate faced by German diplomats in Egypt at the beginning of the 1950s. ${ }^{6}$

In this article, I will focus on two questions. The first question concerns whether German foreign policy sent signals to the Arab world that were understood as support for Arab hostility toward Israel. The most important examples of this are Germany's refusal to establish diplomatic relations with Israel until 1965 and the support provided to Egypt's military and arms industry by German experts. The second question concerns whether there was a transfer of ideas from the Nazi era to the post-war period. In this context, I will examine perceptions of Zionism and how decisions that helped to delegitimize the Jewish state were connected to the Nazi heritage. My research therefore also touches on the issue of the German political elite's relationship with its Nazi past.

\section{THE IMPACT OF GERMAN FOREIGN POLICY ON ARAB HOSTILITY TOWARD ISRAEL}

Usually, the historiography of German-Arab relations begins in 1952. In October of that year, Günther Pawelke, the first West German ambassador, arrived in Cairo. But his arrival was not the first chapter in German-Egyptian relations after World War II. Another group of Germans had arrived two years earlier, led by Dr. Wilhelm Voss, a former high-ranking SS officer (SS-Standartenführer). Voss had been one of Nazi Germany's leading managers. In 1937, he was appointed general manager of the Reichswerke Hermann Göring. During World War II he also headed several large armament conglomerates, mainly in German-occupied Czechoslovakia. Czech companies and trusts were bought or dispossessed and integrated into Nazi conglomerates, two of which were led by Voss (Skoda and Brünner Waffenfabrik). The Göring-Werke employed more than 1.8 million forced laborers, POWs, and concentration camp prisoners. In Voss' area of operations, at least 18,000 people died of brutal abuse, a consequence of the murderous

4 Anwar el-Sadat, Die ägyptische Revolution, Eugen Diederichs Verlag, Düsseldorf, Köln, 1970, p. $55 \mathrm{ff}$.

5 Cf. Records "von Leers" in Political Archive of the German Ministry of Foreign Affairs (hereinafter, PA AA), AV Neues Amt Kairo, vol. 18.933. See particularly the report of Ritter to Bonn, March 12, 1957, ibid.

6 Cf. Bernard Lewis, Semites and Antisemites, New York/London, 1986, p. 160. 
violence of the SS police state that was imported into the war economy and the concept of "annihilation through work," which was first implemented at the Reichswerke. ${ }^{7}$ Voss was also a member of the so-called "circle of friends of Heinrich Himmler" (until 1935 the "circle of friends of the Reichsführer SS"), a group of about 40 leading SS officers, Nazis, and German industrialists who advised the Nazi Party on economic matters and supported the party financially. Voss thus belonged to the elite circles of the Nazi regime. ${ }^{8}$

Voss arrived in Egypt at the end of 1950, after spending time in an American detention camp and under house arrest in Germany for about five years. He was stationed in the Ministry of War, where he laid the foundations for the Egyptian arms industry. He also brought several former generals and officers of the German armed forces to Egypt. This group of advisers, who served from 1951 to 1958, was comprised of up to 60 German officers. Wilhelm Fahrmbacher, a former general, headed the subgroup that was located within the Egyptian army. ${ }^{9}$ Fahrmbacher's office was next to the office of the Egyptian Chief of Staff, and they worked closely together. ${ }^{10}$ Although the advisers stressed that their job was purely of a consultative nature and that they did not hold command positions, they were clearly involved in military preparations. Beyond documents concerning consultation on operative, strategic, and tactical questions, Ihave also found plans for military operations against Israel in Fahrmbacher's papers. ${ }^{11}$ The group came to Egypt when King Farouk was still in power. However, Voss and Fahrmbacher kept their positions after the coup against Farouk in July 1952. According to CIA sources, Fahrmbacher helped the "free officers," the circle around Nasser and Naguib, to prepare a plan for the army's internal control in Cairo in case there would be a revolution. $^{12}$

Voss accompanied Egyptian officials on their trips to Germany and served as an intermediary to German industrial circles. He also maintained contacts with West German officials in the Foreign Office, the Trade Ministry, the Chancellery, and the Ministry of Defense, which was then in the process of being set up. Some observers considered his

7 August Meyer, Das Syndikat. Reichwerke "Hermann Göring," Braunschweig, 1986, pp. 146-148.

8 Cf. digest of the protocols of the interrogation of Dr. Wilhelm Voss by Mr. Barr in Nuremberg on December 11, 1946, December 20, 1946, January 23, 1947, January 15, 1947, January 31, 1947, and April 16, 1947 in PA AA, B11, vol. 739.

9 For information on Wilhelm Fahrmbacher, see his papers in Militärarchiv-Bundesarchiv (Freiburg/Germany), N194. In 1941, Fahrmbacher was commanding general of the VII Battalion that was involved in the war against Russia. From 1942 to 1945, he was a commanding general in Brittany and Normandy, France.

10 See report of Wilhelm Fahrmbacher on his activities in Egypt in Militärarchiv-Bundesarchiv, Papers Fahrmbacher, N194, vol. 27, p. 14.

11 Hubert Diermayer, "Graphic representation of my memo 'How foundation of organization and mobilization is laid,'" July 1954, in Papers Fahrmbacher, Militärarchiv-Bundesarchiv, Bestand N194, vol. 12, p. 134-140. Oskar Munzel, a member of the German military experts group, announced in 1953 that the Egyptian army was primarily preparing for a war with Israel. See British Embassy Cairo to Foreign Office, February 6, 1953, PRO FO 371/102869, quoted in Michael Wolffsohn and Ulrich Brochhagen, Hakenkreuze unterm Burnus? Großbritannien und die deutschen Militär-

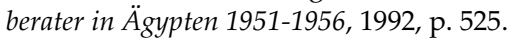

12 CIA report, September 5, 1952, in National Archives II, CIA Name Files, 2nd Release, RG 263, Box Nr. 133. 
influence in Cairo and Germany to be higher than that of Germany's official ambassador, Günther Pawelke, and rumor spread in intelligence circles that Voss would soon become an official West German representative. ${ }^{13}$

The position of Günther Pawelke, the first official German ambassador to Egypt, was therefore not easy. The Foreign Ministry expected him to cooperate with Voss, and while the two got along well in the beginning conflicts began to emerge in April 1953, when Pawelke was concerned that Voss was acting against German interests. ${ }^{14}$ One claim was that he was cooperating with Communists, another that he maintained close contacts with the Arab and German circles around Mufti Amin el-Husseini and German businessman Joachim Hertslet, a committed and high-ranking Nazi who had worked for the Reich Ministry of Economic Affairs. Hertslet was the leading force behind a campaign in the Arab states against the German compensation payments to Israel. (The Federal Republic committed itself to supply goods in the amount of DM3.45 billion to Israel and to pay DM 450 million to the Jewish Claims Conference.)

In the end, it was Pawelke who decided to resign and leave Egypt in 1954 after he refused to cooperate with Voss, while the former SS man remained in his position. But Voss' influence also faded, particularly after British Prime Minister Winston Churchill publicly criticized the activities of the ex-Nazis working as military advisers in May 1953 and accused them of training Egyptian guerrilla units that attacked British troops stationed in the Suez Canal zone. The German government then sent an official to Cairo who met with the advisers and gave them strict guidelines. The group was separated into two different units and lost a great deal of its influence with the Egyptian government around 1954. In spite of the British criticism, the above-mentioned German official highly valued the work of the Germans in Egypt, which he described as a "positive political fact" for Germany. He recommended exerting influence on the group and giving them a "feeling of official comradely support."15

I believe that, in utilizing these contacts, the German government also sent a political message to the Egyptian government, signaling that former SS men were accepted mediators and negotiators, not to mention the fact that their function was to assist Egypt in its war against Israel.

\section{THE TRANSFER OF IDEAS FROM THE NAZI ERA TO THE POST-WAR PERIOD}

This brings me to my second point, the question whether there was a transfer of ideas from the Nazi era to the post-war period. I want to illustrate this question by focusing on the case of one diplomat. Wilhelm Melchers was employed in the German Foreign Office from 1925. He was appointed director of the Near East department in December 1939 and held this position until the end of the war. ${ }^{16}$ Jeffrey Herf describes how he was

13 CIA report, August 29, 1952, in National Archives II, CIA Name Files, 2nd Release, RG 263, Box Nr. 133.

14 Note Allardt, June 16, 1953, in PA AA, B2 VS, vol. 186A.

15 Ibid.

16 From 1931 to 1934 he served in the Near East department under the leadership of Fritz Grobba, from 1935 to 1937 he worked at the embassy in Tehran, and from February 1938 to September 1939 he held the position of consul in Haifa. Between 1951 and 1954, Kurt Munzel worked as Melchers' deputy. During the Nazi period, Munzel was the head of the radio department and 
involved in developing antisemitic propaganda for the Arab world. ${ }^{17}$ After the war, from 1951 to 1953, Melchers once again headed the Near East department. He thus wielded considerable influence over Germany's Near East policy and the reestablishment of West Germany's relations with Arab countries. From 1953 until 1957, Melchers was the head of the German embassy in Baghdad. During this time, he was also in charge of the legation in Jordan and for reports on Israel.

The way in which an antisemitic conception of Zionism influenced Melchers' assessment of the Near East conflict after the war is evident from some of his reports. In 1955, he sent a report from Baghdad analyzing Israel's policies, in which he described the Jewish state as being of an "expansionist nature." Israel in its present form, he argued, would establish a "bridgehead" providing the basis for future "generous expansion." An "uncompromising attitude" on the Arab side was therefore understandable, and a peaceful solution to the conflict impossible. The Arabs would "feel safe only after the last Jew had left Palestine."18

This report reveals how deeply Melchers' thoughts were still influenced by Nazi conceptions. The idea that the Jews were intending to combine Palestine with Syria and Transjordan in a "huge Jewish home" had been among the core ideas of Nazi propaganda for the Arab world, as well as predictions concerning the murderous policies of the Jews toward the Arabs in Palestine and elsewhere. ${ }^{19}$ Melchers' conclusion that it was impossible for Arab countries to tolerate even a small Jewish minority on Palestinian soil reveals his anti-Jewish worldview.

In what way did this worldview affect West Germany's foreign policy? The most controversial issues in German post-war Middle East policy concerned the character of German relations with Israel. After the debate on compensation payments in 1952, the main question was whether Germany should establish diplomatic relations with the Jewish state. The debate cannot be explored in detail here; however, the result was that Germany refused to establish diplomatic ties with Israel until 1965. ${ }^{20}$ The decision in favor of this policy was made in 1956, when a secret conference of German ambassadors

responsible for the Nazi propaganda for the Arab world. Thus, two diplomats who had worked on antisemitic incitement were now responsible for reports and assessments on Israel and the Near East conflict in the Foreign Office. Melchers' successor as head of the Near East department, Hermann Voigt, had also been in the service of the Foreign Office since 1921. For a general overview of the staff of the Foreign Office, see Hans-Jürgen Döscher, Verschworene Gesellschaft. Das Auswärtige Amt unter Adenauer zwischen Neubeginn und Kontinuität, Akademie-Verlag, Berlin, 1995; cf. also Eckart Conze, Norbert Frei, Peter Hayes, and Moshe Zimmermann, Das Amt und die Vergangenheit. Deutsche Diplomaten im Dritten Reich und in der Bundesrepublik, Munich, 2010.

17 Herf, supra note 2, at pp. 38, 55, 74 and other pages.

18 Melchers to Foreign Office, March 21, 1955, in PA AA, Papers Wilhelm Melchers, Bd. 64.

19 See Herf, supra note 2, at p. 102.

20 It is typical for the German context that politicians did not openly announce this policy. In negotiations with Israeli intermediates, German politicians instead stressed that they were willing to establish relations at a later date. For an overview, see Dominique Trimbur, De la Shoah à la réconciliation? La question des relations RFA et Israël (1949-1956), Paris, 2000; Yeshayahu A. Jelinek (ed.), Zwischen Moral und Realpolitik. Deutsch-israelische Beziehungen 1945-1965. Eine Dokumentensammlung, Gerlingen, 1997, p. 44ff; Niels Hansen, Aus dem Schatten der Katastrophe: die deutschisraelischen Beziehungen in der Ära Konrad Adenauer und David Ben Gurion. Ein dokumentierter Bericht, Düsseldorf, 2002. 
who represented Germany in Middle Eastern states took place in Istanbul. The German ambassadors attending the conference unanimously opposed the establishment of diplomatic relations with Israel, fearing protests from Arab countries and - as a consequence-Arab diplomatic recognition of the German Democratic Republic (GDR). They even voted against the establishment of a trade mission, which was subsequently cancelled despite prior promises. ${ }^{21}$

Wilhelm Melchers was one of the first and most outspoken advocates in this debate. His reasons are expressed in a letter that he sent to the German Foreign Office in July 1955. In this letter, he painted a grim picture of what would happen should Germany establish diplomatic relations with Israel:

The establishment of diplomatic relations with Israel would cause a storm of outrage in Arab countries and would inflict serious damage to our political, economic, and cultural interests. ... It would definitely unsettle the German-Arab friendship anddue to the Arab mentality - would turn friendship into hate, because the Arab countries would not forgive the betrayal of a good friend. ${ }^{22}$

Melchers here refers to a crucial point. Arab diplomats were convinced that Germany had acted under foreign pressure when it signed the Luxembourg Treaty, which regulated the compensation payments to Israel, in 1952. After Germany regained its sovereignty in 1955, the Arab world expected the German government to refrain from any step in favor of Israel. It is clear that Melchers was well aware of the anti-Israel component of the so-called German-Arab friendship. Moreover, he was clearly unwilling to give up the advantages he expected to obtain from Germany's Nazi legacy.

The idea that Germany had been forced to sign the Luxembourg Treaty was indeed very widespread in the Arab world. Although this was not true, it is correct that the compensation payments were not very popular in Germany or among German politicians. Inside the Foreign Office in West Germany, however, overt Nazi-like antisemitism and anti-Zionism was taboo. Germany's main aim in foreign policy was to be integrated economically and strategically in the Western alliance. It was crucial to establish a new image of a democratic society and to demonstrate a new beginning. As the U.S. High Commissioner John McCloy observed, Adenauer understood that "the way Germany acts toward the Jews in the future will be the acid test of German democracy." ${ }^{23}$ Consequently, Adenauer often stressed that the compensation payments to Israel that he announced in September 1951 were a "necessity" to regain credibility in the Western world, in order to obtain credit and business contracts. In retrospect, the moral side of the question was not sufficiently emphasized. Historian Wageh Atek

21 Cf. PA AA, B2, vols. 93 and 94.

22 Melchers to Foreign Office, July 29, 1955, quoted in Jelinek, supra note 20, at p. 342ff. German diplomats feared that Germany would consequently lose important economic contracts, as well as Arab support at the United Nations, and that Arab states would support the East German socialist state instead. In addition, the Federal Republic would face heavy losses in the cultural arena. The future of German schools in the Arab world would also be in trouble. At the conference in Istanbul, Melchers added another argument: The lives of German embassy staff and members of the German colonies would no longer be safe. See PA AA, B2, vols. 93 and 94 .

23 John McCloy on July 30, 1949, quoted in: Kurt Birrenbach, Meine Sondermissionen. Rückblick auf zwei Jahrzehnte bundesdeutscher Außenpolitik, Düsseldorf/Vienna, 1984, p. 84. 
quotes Egyptian sources revealing that Adenauer personally stated in front of an Arab delegation that the issue of reparations to Israel had been regulated in accordance with the wishes of the United States. ${ }^{24}$ Under-Secretary of State Hallstein reportedly said to the Egyptian Consul General in Frankfurt: "It is not possible not to sign the agreement. Israel through the Jewish magnifying glass in America and England is stronger than one assumes. It is impossible for the federal government to take counter-action." ${ }^{25}$ In those statements, the antisemitic stereotype of Jewish power was given a new lease of life. It is therefore not surprising that many Arab politicians and journalists were under the impression that antisemitic and anti-Israeli views still prevailed in Germany and that the German government would have supported the Arab side in the conflict if it had been completely sovereign.

The above statement is not documented in German protocols of meetings between Hallstein and Egyptian representatives. According to German sources, Hallstein explained, on the one hand, that the decision to sign the Luxemburg Treaty originated from the desire of the German people to "wipe away" the "blemish" on the German honor resulting from the crimes against the Jews. On the other hand, he emphasized that Germany was not able not to ratify the agreement, as this would be "suicide." 26 Melchers made a similar argument in a meeting with the King of Jordan. He wired to Bonn that he had informed King Hussein that "the Arabs could not expect Germany to commit suicide, only to save their Arab friends from harm...." ${ }^{27}$ Moreover, Chancellor Adenauer argued that the "power of the Jews, particularly in America" was one of the most important reasons for him to seek reconciliation with the Jewish people. ${ }^{28}$

\section{CONCLUSION}

In these and similar statements, German politicians and diplomats highlighted that they had not been completely free in their decisions. It is therefore not surprising that German diplomats failed to convey the message of a new, non-antisemitic Germany to the Arab states until 1965. This failure became obvious in a report sent to Bonn from the German embassy in Cairo in the summer of 1964. This report stated that the Egyptian government was convinced of the "existence of another, real, national Germany" that was hiding behind the official one. Nasser perceived the official Germany to be under pressure from Zionist circles and tried to encourage the "hidden Germany" to emerge for closer cooperation with Egypt. ${ }^{29}$ This analysis was made after President Nasser gave an exclusive interview to the Deutsche National-und Soldatenzeitung, a radical right-wing

24 Wageh Atek, "Der Standpunkt Ägyptens zur westdeutschen Wiedergutmachung an Israel," in Orient 24(3), 1983, pp. 470-485.

25 Cf. Note 75, October 17, 1952, from the Egyptian Consulate General in Frankfurt to the Egyptian Foreign Office in Cairo, File: "Reports from the Egyptian Consulate General from Germany 1952-1953". Quoted in Atek, supra note 24, at p. 476.

26 Meeting of Hallstein with an Arab delegation, October 22, 1952, in PA AA, B11, vol. 252.

27 Melchers to Foreign Office in Bonn, December 28, 1953, in B11, Bd. 1389.

28 Adenauer in an interview on Sender Freies Berlin with Günter Gaus, December 29, 1965.

29 Report on National Socialists and German scientists in Egypt, undated, author unknown. This report was written by a journalist who was in close contact with the embassy and clearly had access to embassy files. See PA AA, B36, vol. 140. 
German journal circulating in Nazi circles, in May 1964. In this interview, Nasser described the Holocaust as a "myth" and announced that Egypt would crush Israel. ${ }^{30}$

During the 1950s and early 1960s, German diplomats in Arab countries were aware of the fact that they enjoyed considerable advantages in Arab countries compared to other Western states because of their refusal to establish diplomatic relations with Israel. In the words of von Waldow, a legation councillor at the German embassy in Baghdad:

There has been a strong argument in favor of the Federal Republic: the fact that Germany, in contrast to other Western democracies, has no diplomatic relations with the State of Israel. If we lose this argument in the future, the only defensive weapon we possess will be beaten out of our hands. ${ }^{31}$

Voices like these dominated the debate in the Foreign Office at that time. Antisemitism in the Arab states was not criticized by German diplomats, nor was Holocaustdenial. Former high-ranking German Nazis were accepted as interlocutors in Egypt. A highly ambivalent policy toward Israel added to the deligitimization of the Jewish state. The episodes described in this article show how strongly antisemitism and complicity with Arab hostility toward Israel informed Germany's foreign policy in the post-war years.

30 "Krieg mit Israel unvermeidbar. Warnung an Bonn, doch Liebeserklärung an Deutschland." Interview with Gamal Abdel Nasser in Deutsche National- und Soldatenzeitung, May 1, 1964.

31 Note von Waldow, July 26, 1955, quoted in Jelinek, supra note 20, at p. 340. 


\title{
Great Expectations: Antisemitism and the Politics of Free-Speech Jurisprudence
}

\author{
Stephen M. Feldman*
}

This essay addresses two related questions. First, is anti-Zionist expression a type of hate speech (specifically, antisemitic hate speech)? Second, from the standpoint of American constitutional law, is (antisemitic) hate speech constitutionally protected under the first amendment? My thesis is that both questions are inherently political, and, as such, they cannot be answered definitively. To say that these questions (or answers to the questions) are political does not mean that we cannot rationally discuss or debate answers to the questions, but rather that we can never arrive at a non-controversial conclusion. One's answers will necessarily reflect or manifest one's interests and values, including religious and other cultural values. ${ }^{1}$

I will initially address the second question - the question of first-amendment protections - and, in fact, the bulk of this essay focuses on this question. Toward the end of the essay, I will return to the first question and explain its relationship to the firstamendment issue. $^{2}$

\section{POLITICS AND FREE-SPEECH JURISPRUDENCE}

Although many constitutional scholars deem free expression to be a constitutional lodestar, ${ }^{3}$ the United States Supreme Court has rarely resolved free-expression issues contrary to mainstream interests or values. The corollary to this point is that political and cultural outsiders or minorities often suffer at the hands of the Court, including in cases that appear to be great victories for free expression. Many cases that have upheld first-amendment rights involved situations where the protected expression attacked or injured outsiders or minorities.

* Jerry W. Housel/Carl F. Arnold Distinguished Professor of Law and Adjunct Professor of Political Science, University of Wyoming. I thank Ken Marcus for inviting me to present this paper at the 2010 YIISA/IASA conference on Global Antisemitism held at Yale University.

${ }^{1}$ I discuss the politics of free expression more extensively in STEPHEN M. FELDMAN, FREE EXPRESSION AND DEMOCRACY IN AMERICA: A HISTORY (University of Chicago Press, 2008).

2 I have discussed the relationship between antisemitism and the first-amendment issue of the separation of church and state in STEPHEN M. FELDMAN, PleAse DON'T WiSH ME A MERRY CHRISTMAS: A CRITICAL HiStORY OF THE SEPARATION OF CHURCH AND STATE (N.Y.U. Press, 1997).

3 E.g., G. Edward White, The First Amendment Comes of Age: The Emergence of Free Speech In Twentieth-century America, 95 MicH. L. REV. 299, 300-01 (1996). 
Two cases involving free speech in a hostile audience situation are illustrative. A hostile audience case arises when a speaker addresses a large group of people who begin to get upset and threaten possible violence. The speaker is humming along, "Blah, blah, blah," but people in the crowd start to complain, "Murmur, murmur, murmur." Perhaps, a couple of people in the crowd start pushing or shoving. Someone might yell, "You better shut up!" In these situations, the police have sometimes arrested the speaker for a crime such as breach of the peace or disorderly conduct. Hence, the Court has needed to address the constitutional question: does the first amendment protect the speaker's expression even though it might generate violence (albeit violence against the speaker)?

In Terminiello $v$. Chicago, a hostile audience case decided in 1949, the Supreme Court concluded that the defendant's conviction under a disorderly conduct ordinance was unconstitutional. The speaker was a Roman Catholic priest, so in the context of the United States in the 1940s, one could possibly maintain that the Court protected the speech of a religious outsider. But the priest's speech was an antisemitic diatribe. He condemned "atheistic, communistic Jewish or Zionist Jews." He claimed that Jewish doctors had performed atrocities on Germans, and he asked, "Do you wonder [that] they were persecuted in other countries?" Then he proclaimed that "we want them to go back where they came from." 4 The American Jewish Congress filed an amicus curiae brief that emphasized the frightening threat posed to Jews by such antisemitic hate speech, especially coming so soon after the Nazi Holocaust. ${ }^{5}$ Nonetheless, the justices held that the first amendment protected the speech.

Two years later, in 1951, the Court decided another hostile audience case, Feiner $v$. New York, but this time, the Court held the speech unprotected. The defendant, Feiner, was a college student who had spoken to a racially mixed crowd of seventy-five to eighty whites and blacks gathered together on a sidewalk in Syracuse, New York. He had encouraged the audience to attend a meeting of the Young Progressives of America, protested the city's cancellation of a permit for an earlier Young Progressives meeting, and made derogatory remarks about "President Truman, the American Legion, the Mayor of Syracuse, and other local political officials." The Court held that the first amendment did not protect this speech because, according to the Court, the speech created a clear and present danger, even though the evidence suggested otherwise. The justices seemed especially worried that Feiner had urged African Americans to "rise up in arms and fight for equal rights." Yet, witnesses had sworn that Feiner had instead encouraged his listeners to "rise up and fight for their rights by going arm in arm to the [Young Progressives meeting], black and white alike." 6

If we compare these two hostile audience cases, in the first, Terminiello, the Court protected inflammatory antisemitic speech, while in the second, Feiner, the Court allowed the punishment of speech largely criticizing public officials and encouraging African Americans to take political action. What is my point here? I am not arguing that the justices purposefully discriminated against outsiders or minorities (or peripheral groups), but rather that the convergence or lack of convergence of interests between

4 Terminiello v. Chicago, 337 U.S. 1, 20-22 (1949) (Jackson, J., dissenting).

5 Brief of the American Jewish Congress as Amicus Curiae, at 9-21, Terminiello v. Chicago, 337 U.S. 1 (1949) (Oct. Term, 1948, No. 272).

6 Feiner v. New York, 340 U.S. 315, 317 (1951); id. at 324 \& n. 5 (Black, J., dissenting). 
outsiders and the mainstream can influence the Court's decisions. Derrick Bell has labeled this phenomenon the interest convergence thesis. ${ }^{7}$

Pursuant to the interest convergence thesis, the results in Terminiello and Feiner suggest that the Court is most likely to emphasize the principled protection of free expression when the speech or writing attacks or harms outsiders or minorities rather than the American mainstream or elites. Thus, in Terminiello, the Court found antisemitic hate speech to be constitutionally protected, while in Feiner, the Court found speech threatening the mainstream and elites to be unprotected.

A landmark free speech case, Brandenburg $v$. Ohio, decided in 1969, further illustrates this point. In Brandenburg, the Court articulated its most speech-protective standard ever for determining when subversive advocacy or, more generally, speech inciting unlawful conduct, would be outside of first-amendment protections and therefore punishable. Yet, one should not overlook that the defendant was a Ku Klux Klan leader who spouted typical hate speech, repeatedly denouncing blacks and Jews and warning that "if our President, our Congress, our Supreme Court, continues to suppress the white, Caucasian race, it's possible that there might have to be some revengeance taken." 8

Another landmark free speech case, New York Times v. Sullivan, decided in 1964, underscores how the Court tends to protect the expression of outsiders when doing so converges or corresponds with predominant interests, values, or practices. The Times had published a full-page advertisement soliciting support for the civil rights movement. The advertisement contained several minor factual errors. For instance, it stated that students in Montgomery, Alabama, had sung "'My Country, 'Tis of Thee' on the State Capitol steps," but they had, in fact, sung the national anthem. Because the advertisement also criticized police reactions to civil rights protests, the police commissioner, Sullivan, brought a civil action in the state courts for defamation against the Times and four civil rights leaders (whose signatures had appeared at the bottom of the advertisement). Sullivan won in the state courts; in fact, the state's highest court upheld a jury award for $\$ 500,000 .^{9}$

A unanimous United States Supreme Court reversed and issued one of its most vigorous defenses of free expression. The Court articulated the highly speech-protective actual-malice standard for determining when a public official could recover damages in a civil suit against the press. A "public official" can recover "damages for a defamatory falsehood relating to his official conduct" only if "he proves that the statement was made with 'actual malice' - that is, with knowledge that it was false or with reckless disregard of whether it was false or not."10

New York Times enunciated a strong conception of a free press, and, of course, the press celebrated the decision. But as the legal historian Lucas A. Powe emphasized, New York Times was "a race case first and foremost."11 It not only protected the expression of black civil rights leaders but also assured that news media, like the Times, could continue to report the atrocities inflicted on civil rights activists in the South. The Court's protec-

7 Derrick A. Bell, Brown v. Board of Education and the Interest-Convergence Dilemma, 93 HARV. L. REV. 518 (1980).

8 Brandenburg v. Ohio, 395 U.S. 444, 444-47 (1969).

9 New York Times v. Sullivan, 376 U.S. 254, 256-59 (1964).

10376 U.S. at 279-80.

11 Lucas A. Powe, JR., THe WARren COURT AND AMERICAN Politics 309 (2000). 
tion of the civil rights leaders and the press went hand-in-hand; news reporting, particularly on television, had helped nurture a national political coalition pushing for civil rights reform. This coalition had begun developing in the 1950s and reached its apex of power in the mid-1960s, as demonstrated by the congressional passage of the Civil Rights Act of 1964 and the Voting Rights Act of 1965. Thus, New York Times did not show the Court baldly and boldly protecting a minority group's constitutional rights regardless of the political fallout. To the contrary, the decision manifested the Court's compliance with a dominant national political coalition that was at its maximum power. ${ }^{12}$

Taken together, these four cases-Terminiello, Feiner, Brandenburg, and New York Times-demonstrate a crucial point: the judicial determination of the scope of firstamendment protections is integrally political. The justices decide cases in accordance with the interests and values at stake. To be clear, I am not suggesting that the political nature of these cases manifests a corruption of the adjudicative process. Rather, politics is inherent to constitutional interpretation and adjudication, when accurately described. ${ }^{13}$

Thus, the constitutional protection of hate speech qua hate speech, including antisemitic hate speech, is necessarily a political issue. The Court has decided several cases involving hate speech, but the Court has not yet explicitly held whether hate speech is or is not a low-value type of expression outside of first-amendment protection. With that said, though, the justices seem to be leaning strongly toward the conclusion that hate speech is constitutionally protected. If so, then the government, of course, would be precluded from criminally punishing such speech. ${ }^{14}$ Yet, to underscore the basic point, the judicial determination of whether hate speech is constitutionally protected in any particular case will be largely influenced by the interests and values at stake.

\section{IS ANTI-ZIONISM HATE SPEECH?}

Now, I can return to my first question: is anti-Zionist expression a type of hate speech (specifically, antisemitic hate speech)? Most commentators agree that one can criticize Israel without being antisemitic. For example, one might argue that Israel's policy on new settlements is incorrect; such an argument is not necessarily antisemitic. It might merely be an argument about the justice and politics of settlements. ${ }^{15}$

Simultaneously, many commentators agree that many anti-Israel arguments are blatantly antisemitic. For an example, I draw on the writings of Ken Marcus, who has described a situation that arose at the University of California at Irvine.

At [UC Irvine], pro-Israel Jewish students have been subject to stalking, rock throwing, and various forms of intimidation, and a Holocaust memorial was damaged or destroyed. Signs have been posted on campus showing a Star of David dripping with

12 See MARY L. DUDZIAK, COLD WAR CIVIL RIGHTS (2000) (discussing the development of a political coalition supporting civil rights).

13 See Stephen M. Feldman, The Rule of Law or the Rule of Politics? Harmonizing the Internal and External Views of Supreme Court Decision Making, 30 L. \& SOC. INQUIRY 89 (2005) (discussing the interrelation of law and politics).

14 Virginia v. Black, 538 U.S. 343 (2003); R.A.V. v. City of St. Paul, Minnesota, 505 U.S. 377 (1992).

15 E.g., Allan C. Brownfeld, Settlements and Peace: Consensus Grows That Israel Cannot Have Both, 20 THE WASHington RePORT ON Middle EAST AfFairs 69 (Sept. 30, 2001). 
blood. Speakers at campus events have chastised Jews for arrogance and have spoken of the distinction between the "good Jews" and the "bad Jews."16

Yet, as Professor Marcus points out, some people would deny that even these statements and actions are antisemitic.

In any event, I would add a broader point: arguments criticizing Israel fall along a continuum, ranging from the "overtly antisemitic" to the "non-antisemitic." Many arguments might fall somewhere on the continuum other than at the two extreme ends. For instance, when debating the appropriateness of new Jewish settlements, if a discussant focuses on the consequences of settlements for the long-term peace process, then the argument would probably not be antisemitic. But if the discussant adds that Israelis are the new Nazis, then the argument has shifted to the antisemitic side of the continuum.

So, how does this question - whether anti-Zionist expression is a type of (antisemitic) hate speech - relate to the question of first-amendment protections, including the firstamendment protection of hate speech? Well, if even the legal question of whether particular expression is protected under the first amendment is necessarily political, then the specification of anti-Zionist speech as being either antisemitic or not will also necessarily be political. In other words, the question whether somebody who criticizes Israel is simultaneously condemning Jews as a race or religion is an inherently political problem: one's interests and values vis-à-vis Israel and Judaism will strongly influence the answer that one gives to this question.

Thus, when critics of Israel insist that their arguments are merely political and not antisemitic, they often are begging the question because whether anti-Zionism is political or antisemitic is itself a political question. This key point is something of a logical conundrum and therefore bears some clarification. Many commentators see a dichotomy, an either/or: criticisms of Israel are deemed either political - and, consequently, legitimateor antisemitic-and, consequently, illegitimate. But this dichotomy, this distinction between political anti-Zionist arguments, on the one hand, and antisemitic (or hatespeech) anti-Zionist arguments, on the other hand, is too slippery to resolve these disputes definitively. It is too slippery because the distinction itself is political: we cannot determine whether anti-Zionism is merely political or is instead hate speech without accounting for our political interests and values, particularly vis-à-vis Israel itself.

\section{CONCLUSION: EXCESSIVE EXPECTATIONS?}

If both questions raised at the outset-first, is anti-Zionist expression a type of hate speech, and second, is (antisemitic) hate speech constitutionally protected under the first amendment-lead to inherently political answers, then what follows? First, we must guard against having expectations for law that are too great. The law, or legal doctrine, cannot eliminate antisemitism. It cannot prevent people from sometimes making antiZionist arguments that are antisemitic because, in part, the law itself cannot be separated from the underlying political battles regarding Israel and Zionism. If antisemitism spreads through society, we should not expect the law to save us.

16 Kenneth L. Marcus, Jurisprudence of the New Anti-Semitism, 44 WAKE FOREST L. REV. 371, 383 (2009). 
Nonetheless, and this is a second conclusion, I do not mean to suggest that we should therefore disregard the law. The law, or the interpretation of law, is inherently political, but the law can simultaneously influence politics. While I have focused on American constitutional law, we should not forget the importance of statutory law. Legislatures might enact statutes that encourage positive results or developments, such as the reduction of antisemitism in society or the control of the detrimental effects of antisemitism (though, of course, legislatures must act within constitutional restraints). And even within the realm of constitutional law, important distinctions must be kept at the forefront. Constitutional restraints or limits generally apply only to governmental actors and not to non-governmental or private actors. Thus, for instance, a private university might be able to punish the dissemination of antisemitic hate speech, while a public university might be unable to do so (depending on the judicial interpretation of the first amendment).

Ultimately, we obviously need to find ways to stop the spread of antisemitism. Law might play a role here, but we need to think about other means as well. 


\title{
A Brief History of Iberian Antisemitism
}

\author{
Lina Gorenstein*
}

\section{BACKGROUND}

In 1449, a discriminatory, racist, and antisemitic set of laws was passed in Toledo. It prohibited any Jew who converted to Christianity, or conversos, from participating in a professional corporation or being admitted to any honorific office of the state or the Church.

Known as the "Purity of Blood Statutes," this legislation discriminated against individuals on the basis of their ethnic origin and was aimed exclusively at Jewish converts to Christianity and their descendants.

Since 1391, the number of converted Jews in Spain had been increasing. This was the year of the "Seville massacres" and the beginning of the conversion movement ordered by Friar Vicente Ferrer.

Traditionally, Jews in the Iberian Peninsula were subject to their own legislation, which was becoming increasingly restrictive. As conversos, they were in the same position as the Christians and could compete with them in every field.

In the realms of Christianity, the specific rights of Jewish communities were displayed in the foros that had been promulgated since the 11 th century. ${ }^{1}$ These provisions regarding the Jews were rarely incorporated into the municipal charters of the various localities. The Jewish community constituted a separate political body, with its own justice and laws, directed by Jewish law or the Torah and the decisions of the Talmudic authorities. ${ }^{2}$ The taxes that the Jewish communities had to pay directly to the King were laid down in those charters and represented an important contribution to the royal treasury. The autonomy of the judarias ${ }^{3}$ was reinforced, and laws were issued reaffirming the autonomy of the Jews and assuring the safety of their property, regulated by the charters and submitted to the King.

From the 14th century, canonical legislation became more prevalent in the realms of Iberian Christianity. Legislation concerning Jews had already been applied across the rest of Europe. This was restrictive legislation, ${ }^{4}$ aimed at prohibiting familiarity between

* Researcher, Laboratory for Studies on Intolerance, University of Sao Paolo.

1 Foro means charter or constitutional laws. See Benzion Netanyahu, The Origins of the Inquisition in Fifeenth Century Spain (New York, Random House 1995) Chapter II: The Spanish Scene.

2 Leon Poliakov, De Maomé aos marranos, 2nd ed. (São Paulo, Perspectiva 1996) p. 94.

3 Judaria refers to a Jewish neighborhood.

4 Renata Sancovsky, Inimigos da Fé-judeus, conversos e judaizantes na Peninsula Ibérica, século VII (Rio de Janeiro, Imprinta 2008). 
Jews and Christians. It had already been introduced by the Lateran Council in 1215 but was only enforced in the Iberian Peninsula in the 14th century.

The tolerance and familiarity that ruled the relationship between Christians and Jews were slowly deteriorating. Since the middle of the 13th century - the end of the Christian Reconquista - the normalization of life in Christian society offered a fertile soil for antisemitism and traditional negative attitudes toward the Jews.

In the 14th century, the popular belief that Jews were poisoners and a destructive element within Christianity was spread throughout Europe, and they were blamed for the plague that devastated Europe in 1348.

Anti-Jewish feeling was growing, and the Jews were expelled from England, France, and some German cities. It is this environment that provides the context for the "Seville massacres" of 1391 in Castela. ${ }^{5}$

The situation was different now, and the Old Christians reacted to this freedom by attempting to use legislation to limit competition from the converted Jews. In Toledo in 1449 , a rebellion against the conversos - accusing them of being responsible for the rise in taxes - resulted in the promulgation of the Sentencia-Estatuto, known as the "Purity of Blood Statutes." 6

The Sentencia-Estatuto was both a judgment and a legislative act against the conversos. In reality, it was a measure based on economic motives, but those responsible for this discriminating legislation used religious pretexts. They accused all the conversos of being secret Jews and, therefore, of being bad Christians. It did not matter what the conversos did: Judaism was in their blood, and they drank it in with their mother's milk. ${ }^{7}$

This was the first racial institutional legislation since the canonical laws. Conversosor New Christians - were not equal to the Old Christians and would never be, since they carried in their blood the seeds of "impurity," the seeds of Judaism.

This racist politics against the conversos accused them all of being false Christians. It reflected a conflict between the Old and the New Christian bourgeoisie-a competition for the work and trade markets.

This anti-Jewish politics reached its peak in 1492, when the kings of Spain presented the Jews with a choice between conversion or leaving the kingdom. The Edict of Expulsion was published on March 31, 1492 and gave the Jews until August to leave Spain.

These statutes were social and urban phenomena, with the purpose of stopping the converted middle class from competing in professional corporations and public office and blocking their social ascent. The statutes lasted for almost three centuries in the Iberian countries and its dominions, always favoring the Old Christian upper classes.

5 Poliakov, supra n. 2, at p. 130.

6 The Sentencia-Estatuto has been studied by many historians, who devoted themselves to discussing the reasons that led to this state of affairs. See, among many others, A. Sicroff, Los Estatutos de Limpieza de Sangre, trad. M. Arminõ (Madrid, Taurus 1958); Benzion Netanyahu, The Origins of Inquisition in Fifteenth Century Spain (New York, Random House 1995); Jaime Contreras, "Limpieza de sangre, cambio social y manipulacion de la memoria," in Inquisicion y conversos - III Curso de cultura hispano-judia y sefardi (Toledo, Associacion de amigos del museo sefardi/caja de Castilla laMancha 1993) pp. 81-102; Christiane Stallaert, Ni una gota de sangre impura (Barcelona, Circulo de Lectores/Galaxia Gutemberg 2006).

7 IAN/TT/IL (Institutos dos Arquivos Nacionais, Torre do Tombo, Inquisição de Lisboa). File of Antonio Rodrigues Mogadouro, letter from Francisco Paes Ferreira attached to the file. 
Dividing society into "pure" and "impure" groups, they excluded the converted from competition.

This legislation provided the basis for a new institution that was introduced in Spain in 1478 and in Portugal in 1536, namely the Court of the Holy Office of the Inquisition. The concept of "purity of blood" was used by the Inquisitorial regime and applied effectively for three centuries. ${ }^{8}$

\section{THE INQUISITION IN PORTUGAL AND BRAZIL}

The New Christians guaranteed the Inquisition an economic basis to maintain itself. ${ }^{9}$ As a socio-economic group independent of religious involvement, the conversos were therefore the subject of the Holy Office. It can be said that the Holy Office of the Inquisition in the Iberian countries was introduced as result of antisemitism that had been in the ascent since the conversions and the massacres of 1391. Iberian antisemitism also had a fundamental biological factor in the form of "blood." The Inquisition was based on genealogical research, which was aimed at finding the ethnic origin of the New Christians. ${ }^{10}$

The main objective of this paper is to show how the Inquisition applied this racial legislation was applied across the Portuguese empire by the Inquisition, particularly in Brazil. On the basis of several examples, it will show how these factors hindered the economic, social, and cultural development of this Portuguese colony from the 16th to the 18 th century.

The main purpose of the Holy Office of the Inquisition was to control the religion of the New Christians - Jews who were all forcibly converted to Christianity in 1497-and their descendants. The existence of the Court of the Inquisition in Portugal made it very dangerous for the New Christians to live and work there. Many converted Jews therefore decided to move to Brazil, where it was easier to escape the vigilance of the Inquisition. The economic possibilities attracted the converts, who found better opportunities in the New World. From the beginning of the 16th century, many New Christians arrived in Brazil. They concentrated mainly in the northeast of the country where the sugar industry was more developed. ${ }^{11}$

Although there was no Court of the Inquisition in Brazil, life was not absolutely secure. For three centuries, its agents-familiares, comissários e visitadores (officials of the Inquisition) - persecuted and arrested New Christians suspected of being secret Jews. At first, the agents operated in the northeast of the country. In the 18th century, they also operated in the southeast, Minas Gerais, and Rio de Janeiro, after gold and diamonds were discovered there.

The Portuguese Inquisition had one main interest: revenue.

The opportunity to assimilate and integrate into mainstream society was greater in Brazil than in Portugal. Many New Christians ceased living as Jews, but a certain group

8 Anita Novinsky, Cristãos novos na Bahia (São Paulo, Perspectiva 1972) p. 43.

9 Ibid.

10 Anita Novinsky, "Anti-semitismo, os marranos e a fluctuation animi," in Maria Luiza Tucci Carneiro, O anti-semitismo nas Americas (São Paulo, EDUSP 2007) p. 31.

11 Anita Novinsky, "Jewish Roots of Brazil," in J. Elkin and G. Merx (eds.), The Jewish Presence in Latin America (Boston, Allan A. Unameris 1987) pp. 33-44. 
remained loyal to their ancient faith for centuries, while externally they behaved exactly like the Old Christians.

At the end of the 16th century, the Inquisition intensified its Brazilian activities in Bahia and Pernambuco. ${ }^{12}$ Many New Christians were denounced as secret Jews and transported to the inquisitorial prisons in Portugal.

From a traveler's diary, we know that Brazil spared from the Inquisition for a relatively long time, but that the latter eventually became so rigorous that merchants were imprisoned and all their goods were confiscated on the slightest suspicion. ${ }^{13}$

Portuguese legislation was also applied in Brazil. Laws regarding the New Christians were issued during the colonial period. In Rio de Janeiro, conversos were prohibited from becoming elected officials. A Royal Decree of 1611 stated that all candidates for municipal offices should be selected from among the noblest people and without "any trace of Jewish blood." 14 In 1643, another municipal decree stated that in Rio de Janeiro people should not be elected from "the nation," meaning Jews. ${ }^{15}$

In Inquisitorial documents, one finds many opinions about the New Christians from their neighbors, business partners, friends, companions, and even their children's godfathers and godmothers. Most of them testified that, externally, the New Christians were good Catholics, following all the practices imposed by the Church. But they were unaware of what they did in the privacy of their homes.

All conversos were baptized, received the sacrament of confirmation, grew up as Catholics, and behaved exactly as the Old Christians. Their external behavior was corroborated by their neighbors but many times accompanied by a certain suspicion. They were "good Christians, but... New Christians."

One example concerns the case of a woman who lived in Rio de Janeiro on her father's plantation, where there was a chapel. After she was married, she continued living on the plantation. The commissioner of the Holy Office of the Inquisition in Rio de Janeiro declared that she had always been a true Catholic and that he never had doubts about her faith. But he did not know if she went to mass or what she did when she was at home. ${ }^{16}$ Another priest said of the same woman that she was a good Christian in her

12 The Visitações of 1590-1595. See Primeira Visitação do Santo Ofício às Partes do Brasil, pelo Licenciado Heitor Furtado de Mendonça (Denunciaçães de Pernambuco, 1593-1595), Introdução de Rodolfo Garcia (São Paulo, Série Eduardo Prado 1929); Primeira Visitação do Santo Ofício às Partes do Brasil, pelo Licenciado Heitor Furtado de Mendonça (Confissões de Pernambuco, 1594-1595), Introdução de José Antônio Gonsalves de Mello (Recife, Universidade Federal de Pernambuco 1970); Primeira Visitação do Santo Ofício às Partes do Brasil, pelo Licenciado Heitor Furtado de Mendonça (Confissões da Bahia, 1591-1592), Prefácio de J. Capistrano de Abreu. 2. ed. (Rio de Janeiro, Liv. Briguiet 1935); Primeira Visitação do Santo Ofício às Partes do Brasil, pelo Licenciado Heitor Furtado de Mendonça (Denunciações da Bahia, 1591-1593), Introdução de J. Capistrano de Abreu (São Paulo, Editor Paulo Prado 1925).

13 D. Ruiters, “A Tocha da navegação," 269 Revista do Instituto Histórico e Geografico Brasileiro (1965) p. 80.

14 Apud Maria Fernanda Baptista Bicalho, A cidade e o Império: o Rio de Janeiro na dinamica colonial portuguesa, séculos XVII e XVIII, mimeo. Tese, FFLCH-USP (São Paulo 1997) p. 354.

15 J.J. de A. Silva, Colleção cronológica da legislação portuguesa - compilada e anotada (1640-1647) (Lisboa, Imprensa de F.X. de Souza 1856) p. 439.

16 IAN/TT/IL, File of Brites de Paredes, Inquisição de Lisboa n. 399, Inquirição do Rio de Janeiro, 10 de julho de 1713 . 
exterior behavior. But as she lived on a plantation, far from the city, he did not know if she believed in the Church sacraments. ${ }^{17}$

There was thus always some uncertainty about the faith of the New Christians.

\section{THE NEW CHRISTIANS IN BRAZIL}

The ethnic origin of Brazilian families was known by the majority of the population of Rio de Janeiro, since they had been established there since the 16th century. François Froger, a French traveler who visited the city in 1695 estimated that three-quarters of the white population was of Jewish origin. ${ }^{18}$ Other documents confirm his opinion.

From the latest research, we know that the New Christians represented around 20-30 percent of Rio de Janeiro's free white population during this period. Part of this New Christian community lived in the city and engaged in urban activities. Around 50 percent of the community was dedicated to agricultural activity, mainly the cultivation of sugar cane and sugar production. Some were owners of large sugar plantations, and some were small-scale farmers. It is interesting to note that some of the sugar-mill owners and farmers were also lawyers, doctors, or businessmen, maintaining a household in the city and upholding a strong family network. ${ }^{19}$

The same families were involved in urban activities, the liberal professions, sugar cane plantations, manufacturing and trade, and trade with the mining region. The work of these families was divided among their members.

One member of the family would be engaged at the sugar mill, another in the city, and a third at the mines, in a typical colonial society relationship, which was patriarchal and agrarian, with large properties and slave labor (the plantations). The rural clan was the main cell of political and social organization, shaping a network of people linked to the clan and interconnected by a wide range of interests. ${ }^{20}$ These clans were the favored victims of the Court of the Inquisition, enabling it to arrest entire families.

When the Inquisition arrived at the beginning of the 18th century, panic reigned among the conversos. More than 300 people were arrested and had their properties confiscated.

More than 20 percent of the sugar mills of the region that belonged to New Christians fell into the hands of the Church, including their businesses, houses, and slaves, as well as their jewelry, gold, and silver.

The Brazilian colony suffered the economic consequences of these confiscations.

\section{IMPACT OF THE INQUISITION IN PORTUGAL}

There was a critical mentality in Portugal among those who understood the harm that the Inquisition was doing to the Portuguese economy. The Ambassador of Portugal to

17 Ibid.

18 François Froger, Rélation d'um Voyage fait em 1695, 1696 et 1697 aux cotes d'Afrique, detroit de Magellan, Brésil, Cayenne et Isles Antilles par um escadre des vasseaux du Roi, commandée par $M$. de Gennes, faite par lê Sieur Froger, Ingenieur volontaire sur lêvaisseu Le Faucaun Anglais, Amsterdam, chez lês héritiers d'Antoine Schelte, MDCXCIX, pp. 74-75.

19 Lina Gorenstein, A Inquisição contra as mulheres: Rio de Janeiro, séculos XVII e XVIII (São Paulo, Humanitas 2005) p. 71.

20 Ibid., at p. 83. 
the Court of Louis XIV, D. Luis da Cunha, wrote that the Inquisition had discovered "the mine of the Jews in Rio de Janeiro," and confiscated their properties to a point that the King had to intervene himself. ${ }^{21}$

Similar criticism was expressed by Antonio Nunes Ribeiro Sanchez, a famous humanist and physician, who also understood that the confiscation of the sugar mills was ruining the sugar trade. ${ }^{22}$

Father Antonio Vieira also recognized the importance of the New Christians to the Portuguese economy, and he advised the King to adopt a more tolerant attitude, mentioning that the Jews were only discriminated against in Portugal and that they lived openly as Jews in the Holy City of Rome. Father Vieira also proposed that the King should welcome back all the Portuguese scattered across Europe, particularly the businessmen who had substantial experience in the field of international trade. ${ }^{23}$

Father Vieira attributed the misery of Portugal to antisemitism, which continued to drive the most important, cultivated, and prosperous Jews and secret Jews from the country.

Portuguese antisemitism was responsible for the backwardness of the Portuguese economy and culture. The Portuguese crown prohibited any development of the colony, including the existence of universities, and they censored books even more rigorously than those included on the Index by Rome. Most of the Portuguese population was illiterate, but all the New Christians condemned by the Inquisition knew how to read and write, including 50 percent of the women arrested. ${ }^{24}$

The anti-Jewish actions of the Church and the state did away with the most cultivated Portuguese poets and writers of the period. Bento Teixeira, who was considered the first poet of America, 25 died in the dungeons of the Inquisition in Lisbon in the 16th century. Antonio Serrão de Castro, ${ }^{26}$ a well-known apothecary and poet who was one of the founders of the first Literary Academy of Lisbon, was incarcerated for ten years and finished his life begging on the streets of Lisbon. Antonio José da Silva, one of the main dramaturgists and greatest writers of the Portuguese language in the 18th century, whose plays are still staged today, was burned at the stake. ${ }^{27}$

After more than ten generations, the descendants of converted Jews were still discriminated against by law. To obtain important jobs and offices, a person had to submit

21 D. Luis da Cunha, Testamento Político (São Paulo, Alfa-Omega 1976) p. 87.

22 Antonio Nunes Ribeiro Sanches, Christãos Novos e Christãos Velhos em Portugal, Prefácio de Raul do Rego, 2. ed. (Porto, Paisagem 1973) p. 74.

23 Antonio Vieira, "Proposta feita a el-rei D. João IV, em que se lhe representava o miseravel estado do Reino e a necessidade que tinha de admitir os judeus mercadores que andavam por diversas partes da Europa," in Obras Escolhidas (Lisboa, Ed. Sá da Costa 1951) Vol. IV, Obras Várias II, pp. 27-71.

24 Gorenstein, supra n. 19, at p. 208.

25 Eneida Ribeiro, “O Marranismo no Brasil Colônia através do processo inquisitorial contra Bento Teixeira," in Helena Lewin (coord.), Judaísmo e Modernidade: suas múltiplas inter-relações (Rio de Janeiro, UERJ/Programa de Estudos Judaicos 2007) pp. 92-102.

26 Benair Ribeiro, Um morgado de misérias - o auto de um poeta marrano (São Paulo, Humanitas 2007).

27 Lina Gorenstein, "A ameaça da intelligentsia brasileira: a família de Antonio Jose," in Helena Lewin (coord.), Judaismo e Modernidade: suas múltiplas inter-relações (Rio de Janeiro, UERJ/Programa de Estudos Judaicos 2007) pp. 78-84. 
detailed information on his ancestors to prove his "purity of blood." Even so, the New Christians achieved high positions in society and managed to gain acceptance to the University of Coimbra, returning to Brazil with academic degrees.

During this period, Portugal had a peculiar administration, and laws were frequently ignored, depending on the interest of the moment. The conversos constituted the intellectual part of society and had the most advanced ideas. They represented the opposite mentality of the conservative, fanatic, and intolerant ruling class.

In the 18th century, the King's minister, the Marques de Pombal, decided to improve the kingdom's backward economic situation. He changed Portugal's political landscape by eliminating the distinction between the Old and the New Christians and ending the Portuguese division between the "pure" and "impure." Discrimination subsequently diminished, and the New Christians were gradually absorbed by society as a whole. In the 19th century, there was no more persecution, but the Inquisition continued as a respectable and venerable institution until its end in 1823.

\section{PRIMARY DOCUMENTARY SOURCES}

IAN/TT - Instituto dos Arquivos Nacionais, Torre do Tombo, Inquisição de Lisboa, Portugal:

File 399, Brites de Paredes, 1713.

File 5412, Antonio Rodrigues Mogadouro, 1672.

\section{BIBLIOGRAPHY}

"A ameaça da intelligentsia brasileira: a família de Antonio Jose," in Helena Lewin (coord.), Judaismo e Modernidade: suas múltiplas inter-relações (Rio de Janeiro, UERJ/ Programa de Estudos Judaicos 2007) pp. 78-84.

"Anti-semitismo, os marranos e a fluctuation animi," in Maria Luiza Tucci Carneiro, $O$ anti-semitismo nas Americas (São Paulo, EDUSP 2007) pp. 27-38.

Bicalho, Maria Fernanda Baptista, A cidade e o Império: o Rio de Janeiro na dinamica colonial portuguesa, séculos XVII e XVIII, mimeo. Tese, FFLCH-USP (São Paulo 1997).

Boxer, Charles, Salvador de Sá e a luta pelo Brasil e Angola 1602-1686, Coleção Brasiliana, Vol. 353 (São Paulo, Cia. Ed. Nacional/EDUSP 1973).

Contreras, Jaime, "Limpieza de sangre, cambio social y manipulacion de la memoria," in Inquisicion y conversos - III Curso de cultura hispano-judia y sefardi (Toledo, Associacion de amigos del museo sefardi/caja de Castilla la-Mancha 1993) pp. 81-102.

Cunha, D. Luis da, Testamento Político (São Paulo, Alfa-Omega 1976).

Froger, François, Rélation d'um Voyage fait em 1695, 1696 et 1697 aux cotes d'Afrique, detroit de Magellan, Brésil, Cayenne et Isles Antilles par um escadre des vasseaux du Roi, commandée par M. de Gennes, faite par lê Sieur Froger, Ingenieur volontaire sur lê vaisseu Le Faucaun Anglais, Amsterdam, chez lês héritiers d'Antoine Schelte, MDCXCIX.

Gorenstein, Lina, A Inquisição contra as mulheres: Rio de Janeiro, séculos XVII e XVIII (São Paulo, Humanitas 2005). 
"Jewish Roots of Brazil," in J. Elkin and G. Merx (eds.), The Jewish Presence in Latin America (Boston: Allan A. Unameris 1987) pp. 33-44.

Netanyahu, Benzion, The Origins of the Inquisition in Fifteenth Century Spain (New York, Random House 1995).

Novinsky, Anita, Cristãos novos na Bahia (São Paulo, Perspectiva 1972).

Poliakov, Leon, De Maomé aos marranos. 2. ed. (São Paulo, Perspectiva 1996).

Sanches, Antonio Nunes Ribeiro, Christãos Novos e Christãos Velhos em Portugal, Prefácio de Raul do Rego, 2. ed. (Porto, Paisagem 1973).

Sancovsky, Renata, Inimigos da Fé-judeus, conversos e judaizantes na Peninsula Ibérica, século VII (Rio de Janeiro, Imprinta 2008).

Sicroff, Albert, Los Estatutos de Limpieza de Sangre, trad. M. Arminõ (Madrid, Taurus 1958).

Silva. J.J. de A., Colleção cronológica da legislação portuguesa - compilada e anotada (16401647) (Lisboa: Imprensa de F.X. de Souza 1856).

Stallaert, Christiane, Ni una gota de sangre impura (Barcelona: Circulo de Lectores/Galaxia Gutemberg 2006).

Ribeiro, Benair, Um morgado de misérias - o auto de um poeta marrano (São Paulo, Humanitas 2007).

Ribeiro, Eneida, “O Marranismo no Brasil Colônia através do processo inquisitorial contra Bento Teixeira," in Helena Lewin (coord.), Judaísmo e Modernidade: suas múltiplas inter-relações (Rio de Janeiro, UERJ/Programa de Estudos Judaicos 2007) pp. 92-102.

Ruiters, D., “A Tocha da navegação," 269 Revista do Instituto Histórico e Geografico Brasileiro (1965).

Vieira, Antonio, "Proposta feita a el-rei D. João IV, em que se lhe representava o miseravel estado do Reino e a necessidade que tinha de admitir os judeus mercadores que andavam por diversas partes da Europa," in Obras Escolhidas (Lisboa: Ed. Sá da Costa 1951) Vol. IV, Obras Várias II, pp. 27-71. 


\title{
Antisemitism in Contemporary Poland
}

\author{
Marek Kucia*
}

\section{INTRODUCTION}

Poland is one of the most significant countries in Jewish history. In the Middle Ages, the Jews found a safe haven in the Kingdom of Poland. In subsequent centuries, they grew into a large community that contributed to the country's welfare and developed a vibrant culture. In the 19th century, 80 percent of the world's Jewry were living on the territories of what was then the Commonwealth of Poland and Lithuania. Because of migrations in the 19th and 20th centuries, many Jews in Israel, America, and other countries have roots in Poland. In the period between the World Wars, three million Jews were living in the Republic of Poland. Constituting 10 percent of the country's population, they were the largest Jewish community in Europe. In 1939-1945, more than 90 percent of the Jews of Poland perished in the Holocaust. The annihilation of six million European Jews occurred largely in what had been Poland. The Nazi German death camps of Auschwitz, Bełżec, Kulmhof, Majdanek, Sobibór, and Treblinka operated there. After World War II, Poland became a country with hardly any Jews. The Jewish community declined, as a result of migration, from 240,000 in 1946 to 40,000 according to estimates - or 1,000 by self-identification-in $2002{ }^{1}$

\section{REPORTED POLISH ANTISEMITISM}

Despite its rich and tragic Jewish past and low number of Jews today, Poland-now an established member of the free world (a member of NATO since 1999 and the European Union since 2004) - is reported to be a rather antisemitic country. For example, a survey that was carried out for the Anti-Defamation League in 2009 found that 55 percent of Poles share the antisemitic opinion that "Jews have too much power in the business world" (see Figure 1). It is of little consolation that the results in Hungary and Spain were higher.

\section{RESEARCH}

The question of the extent and character of antisemitism in today's Poland and how it has changed in recent years are issues that I addressed in a sociological research project

* Director, Institute of Sociology, Jagiellonian University, Kraków, Poland.

1 The number of Jews registered at local Jewish committees in Poland in 1946 was 244,000. The American Jewish Year Book (2003) gave the figure of 40,000 Jews in Poland. A total of 1,055 people identified themselves as Jews in the national census in 2002. 
Figure 1: Anti-Defamation League Survey 2009: "Jews have too much power in the business world" (percentage responding "probably true")

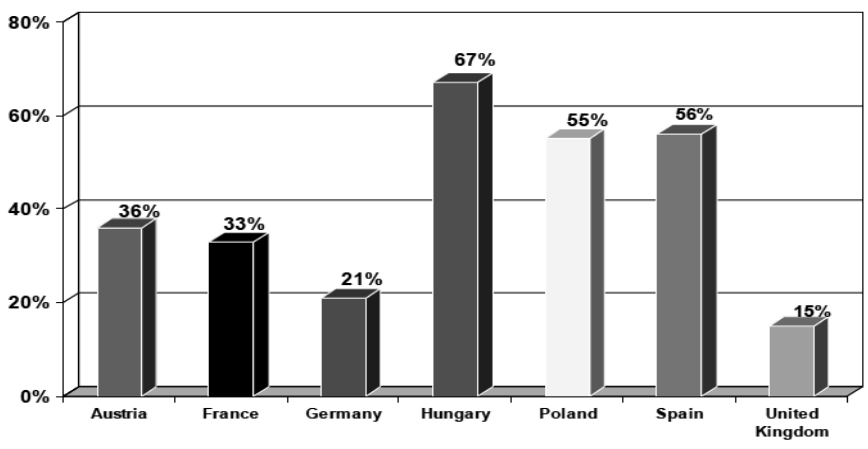

Source: Anti-Defamation League (2009).

carried out in January and June 2010. ${ }^{2}$ The project consisted of two parts - quantitative and qualitative. The quantitative part consisted of a survey that was designed by me and conducted by the Polish member of the Taylor Nelson Sofres network OBOP on January 7-10, 2010 through face-to-face interviews with a country-wide random sample of 1,001 respondents representative of the population of Poland aged over 15 years. The maximum statistical measurement error was $+/-3$ percent for the estimate of 95 percent. The qualitative part of my research project consisted of three focus group interviews that my students and I conducted in June 2010 with different groups of Catholics in different locations: (a) members of the Club of Catholic Intelligentsia in Kraków (six persons); (b) members of the Family of Radio Maryja in Rzeszów (nine persons); and (c) Catholic intellectuals in Lublin (five persons). ${ }^{3}$

In designing the survey and analyzing its results, I drew on Polish sociological research into antisemitism from 1992, 1996, and 2002. The 1992 and 2002 projects were conducted by Ireneusz Krzemiński, a professor of sociology from the University of Warsaw, and his teams from the Institute of Sociology at the University of Warsaw and the Jewish Historical Institute in Warsaw (Krzemiński 1993, 1996, 2004). The surveys were carried out by the PBS opinion polling organization on samples of 1,011 (in 1992) and 1,098 (in 2002) respondents representative of Poland's population aged over 18 years. The 1996 survey was designed and analyzed by Helena Datner (1997), a sociologist from the Jewish Historical Institute in Warsaw who was also a core member of Krzemiński's team in 1992. Datner's survey was conducted by the CBOS polling organi-

2 The research project "Auschwitz in the social consciousness of Poles, 2010 A.D." was financed by the Polish government, the Ministry of Science and Higher Education, grant no. NN116445837. The project concerned antisemitism and the changing perception of Auschwitz in Poland since my Auschwitz research of 2000 (Kucia 2001a, 2001b, 2005).

3 The Clubs of Catholic Intelligentsia bring together moderate Catholics. The one in Kraków is sponsored by Cardinal Dziwisz, former personal secretary to Pope John Paul II. The Families of Radio Maryja are listeners of Radio Maryja - an extreme nationalist and traditionalist Catholic radio station, known for spreading antisemitic views, established and headed by Father Rydzyk. The Lublin intellectuals were graduates or faculty of the Catholic University of Lublin, and funders or supporters of Archbishop Życiński, one of the most open-minded and anti-antisemitic members of the Polish Roman Catholic clergy. 
zation on a sample of 1,097 respondents representative of Poland's adult population (18 years and above).

The main objective of my survey was to determine the level of three kinds of antisemitism: (a) modern antisemitism, expressed in the opinion that Jews have too much power or influence; (b) religious antisemitism, which consists of the belief that Jews are culpable in Christ's death; and (c) what I call post-Holocaust antisemitism, expressed in the opinion that it is good that there are hardly any Jews in Poland as an effect of the Holocaust.

Modern antisemitism was measured by the questions that were designed by Datner and used in her and Krzemiński's surveys:

1. Do you agree with the statement that Jews in our country have too much influence on...?
(a) political life
(b) economic life
(c) press, radio, and television

2. Do you agree with the opinion that Jews have too much influence in the world?

The three items in the first question (used in 1992, 1996, and 2002) probed the political, economic, and media-related antisemitism at domestic level, while the second question (asked in 1992 and 2002) measured what may be termed international antisemitism. Each of these four items was given a four-grade scale to choose one answer: "strongly agree," "somewhat agree," "somewhat disagree," or "strongly disagree," with a few other options: "I don't know, I am not interested," “I am undecided," or "difficult to say."

The four items together constituted the index of modern antisemitism and antiantisemitism as designed by Datner (1996). The positive answers ("strongly agree" or "somewhat agree") to the four items constituted the scale of modern antisemitism: from four positive answers standing for strong modern antisemitism to no positive answers indicating no modern antisemitism. Analogically, the negative answers ("strongly disagree" or "somewhat disagree") to the four items allowed one to construct the scale of modern anti-antisemitism: from four negative answers meaning strong rejection of modern antisemitism to no negative answers expressing no rejection of antisemitism.

Religious antisemitism was assessed by means of a question that Datner designed for the 1992 survey and Krzemiński also used in 2002:

Sometimes one hears the opinion that Jews have so many troubles because God punished them for the crucifixion of Christ. Do you agree with this opinion or not?

To measure post-Holocaust antisemitism, I designed the following question:

One sometimes hears the opinion: "It is true that the Holocaust - the annihilation of Jews - was a major crime, but it is good that as an effect of it there are hardly any Jews in Poland." Do you agree or disagree with this opinion?

As in the case of modern antisemitism, respondents to the questions concerning the two other kinds of antisemitism were able to choose an answer from the same four-grade scale. In addition, there was the "difficult to say" option.

The qualitative part of the research was intended to deepen selected results of the survey. The participants in the focus group interviews were asked, inter alia, to discuss 
what they thought when they heard the various questions that measured antisemitism, particularly what they meant by the word "Jews."

\section{RESULTS}

\section{General findings}

The survey revealed the following (see Figure 2):

Figure 2: Antisemitism and anti-antisemitism in Poland, 2010 (percentage agreeing or disagreeing with antisemitic statements)

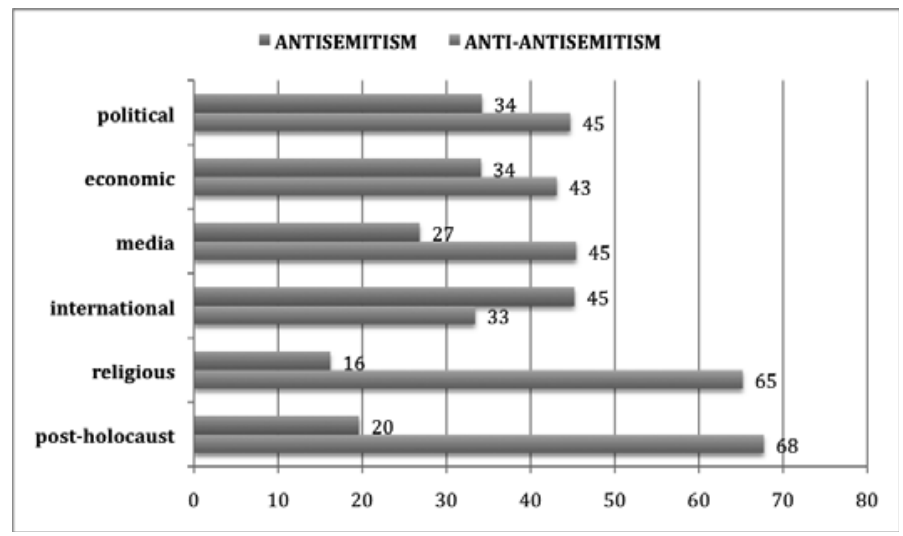

1. A minority of Poles agree with various antisemitic opinions, that is, the majority of Poles are not antisemitic.

2. However, antisemitic opinions are fairly widely spread in Poland.

a. In particular, there are many supporters of international antisemitism, which is expressed through the opinion that "Jews have too much influence in the world." Forty-five percent of Poles agree with this statement. On a positive note, it is the only antisemitic opinion that has more supporters than opponents (33 percent).

b. Many Poles - 34 percent in each case-agree with the opinions that show domestic political and economic antisemitism, that is, that the "Jews in our country have too much influence on political life [and] economic life." Also, 27 percent of Poles agree with the statement of domestic media-related antisemitism, namely that "Jews in our country have too much influence on the press, radio, and television."

c. For a country where most of the Holocaust took place and that lost almost its entire Jewish community as a result, a surprisingly large number of Poles - onefifth (20 percent) of the population-are supporters of post-Holocaust antisemitism, which is conveyed by the opinion "It is true that the Holocaust - the annihilation of the Jews - was a major crime, but it is good that as an effect of it there are hardly any Jews in Poland."

d. The level of religious antisemitism is disturbingly high. In a Catholic country that is the birthplace of Pope John Paul II - who declared any antisemitism to be a sin that has to be confessed and repented for and who recalled that the Church denounced its former teaching that the Jews are culpable in Christ's death - as 
many as 16 percent of people agree with the statement that the "Jews have so many troubles because God punished them for the crucifixion of Christ."

3. Despite the fairly high levels of various kinds of antisemitism in Poland, there are more Poles who reject antisemitic opinions than those who share them (with the exception of international antisemitism).

a. What is particularly encouraging is that 68 percent of Poles reject the statement of post-Holocaust antisemitism and 65 percent dismiss religious antisemitism.

b. What is also positive is that the opinions that express domestic political, economic, and media-related antisemitism each had a relative majority of opponents.

\section{One antisemitism or many antisemitisms?}

The research design adopted for the survey presupposed the existence of several kinds of antisemitism. At the first level, these were the kinds that were measured by each of the six survey questions: political, economic, media-related, international, religious, and post-Holocaust. At the second level (based upon the categorization of survey questions), one can speak of four kinds of antisemitism: domestic (comprised of political, economic, and media-related), international, religious and post-Holocaust. The theory of antisemitism and the results of earlier research allow one to discern three kinds of antisemitism at the third level: modern (encompassing the three domestic kinds and the international kind), religious, and post-Holocaust. A deeper statistical analysis (the factor analysis) of the 2010 survey data revealed a very strong correlation among political, economic, media-related, and international antisemitism. ${ }^{4}$ This confirmed the theoretical assumptions and the findings of Datner and Krzemiński and proved that there exists among Poles a pattern of antisemitic views that are otherwise known as modern antisemitism. Interestingly, the statistical analysis of the 2010 data also showed a fairly strong correlation between religious and post-Holocaust antisemitism, ${ }^{5}$ which

\section{Figure 3: Variety of antisemitism in Poland, 2010}

\begin{tabular}{|c|c|c|c|c|c|c|}
\hline $\begin{array}{l}\text { Level } 5 \\
\text { abstract }\end{array}$ & & & & antiser & & \\
\hline $\begin{array}{c}\text { Level } 4 \\
\text { analytical }\end{array}$ & & & modern & & & \\
\hline $\begin{array}{c}\text { Level } 3 \\
\text { theory- \& research-based }\end{array}$ & & & modern & & relizious & $\begin{array}{c}\text { poss- } \\
\text { Holocaust }\end{array}$ \\
\hline $\begin{array}{c}\text { Level } 2 \\
\text { question categories }\end{array}$ & & domestic & & $\begin{array}{l}\text { inter: } \\
\text { national }\end{array}$ & relizious & $\begin{array}{c}\text { post- } \\
\text { Holocaust }\end{array}$ \\
\hline $\begin{array}{c}\text { Level } 1 \\
\text { survey questions }\end{array}$ & political & cconomic & media & $\begin{array}{l}\text { inter- } \\
\text { national }\end{array}$ & religious & $\begin{array}{c}\text { pose- } \\
\text { Holocaust }\end{array}$ \\
\hline
\end{tabular}

4 The categorial principal components analysis for categorial variables (CATPCA) that was carried out by a member of my research team, Mateusz Magierowski, showed the following values for the results of the four items: political 0.923 , economic 0.933 , media-related 0.871 , and international 0.885 .

5 The CATPCA component values for religious and post-Holocaust antisemitism data were 0.834 and 0.883 respectively. 
allows one to discern a kind of antisemitism that may be termed historical. The modern and historical kinds of antisemitism belong to the forth level. In sum, the research carried out in Poland indicates that antisemitic views seem to fit into a five-level structure (see Figure 3) in which the modern and historical varieties are largely independent entities.

\section{Changes in modern antisemitism and anti-antisemitism}

A major problem that I address in my research is how the antisemitism of Poles, particularly the modern variety, has changed in recent years and whether it has increased or decreased. Also, I am interested in how anti-antisemitism has evolved.

The analysis of strong modern antisemitism, which is measured by the positive answers ("strongly agree" or "somewhat agree") to the questions about political, economic, media-related, and international antisemitism (cf. Datner 1996), showed that it is represented by 22 percent of adult Poles (aged over 18 years). ${ }^{6}$ Twenty-three percent of Poles strongly reject modern antisemitism ("strongly disagree" or "somewhat disagree" answers to all four items). Since the previous survey in 2002, strong antisemitism has declined by five percentage points, and its strong rejection has increased by seven points. Compared to the results of the first survey on antisemitism in 1992, the level of strong antisemitism in 2010 was somehow higher, but its rejection was much higher (see Figure 4). Thus, in 2010, for the first time since antisemitism has been surveyed in Poland, the number of strong antisemites among Poles is lower (albeit only a little) than the number of those who strongly reject antisemitism. This and the decline of strong modern antisemitism between 2002 and 2010 and the steady increase in the strong rejection of antisemitism from 1992, through 2002, to 2010, are positive developments.

Figure 4: Strong modern antisemitism and strong modern anti-antisemitism (percentage agreeing or disagreeing with four antisemitic opinions; respondents aged over 18)

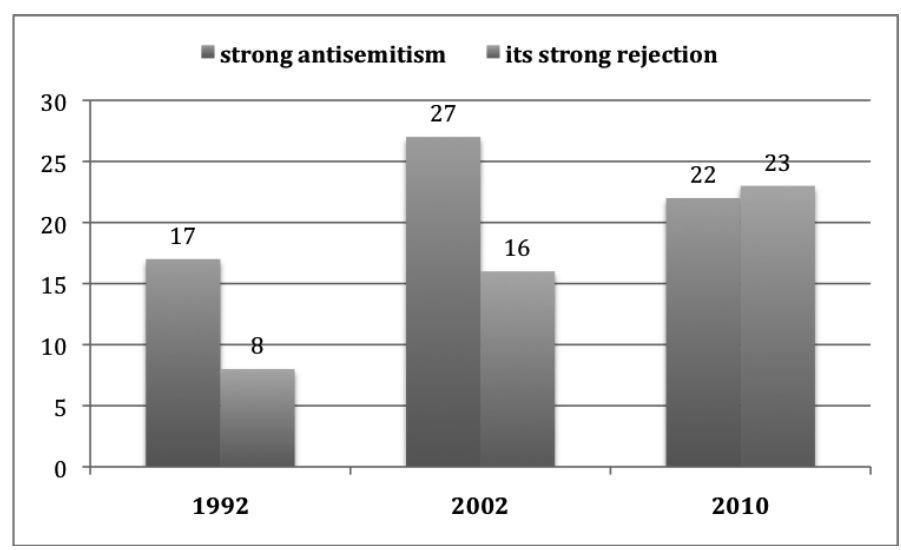

Comparing the data for the three domestic components of modern antisemitism, one can confirm positive developments (see Figure 5). The political, economic, and media-related

6 The precise result was 21.5 percent (for respondents aged 18 or above), while the entire sample, which consisted of respondents above the age of 15 , had strong modern antisemitism at 21.8 percent. 
kinds of antisemitism were all lower than in 1996 and, except for media-related antisemitism, also lower than in 1992.

Figure 5: Domestic antisemitism: political, economic, media-related (percentage agreeing with antisemitic opinions; respondents aged over 18)

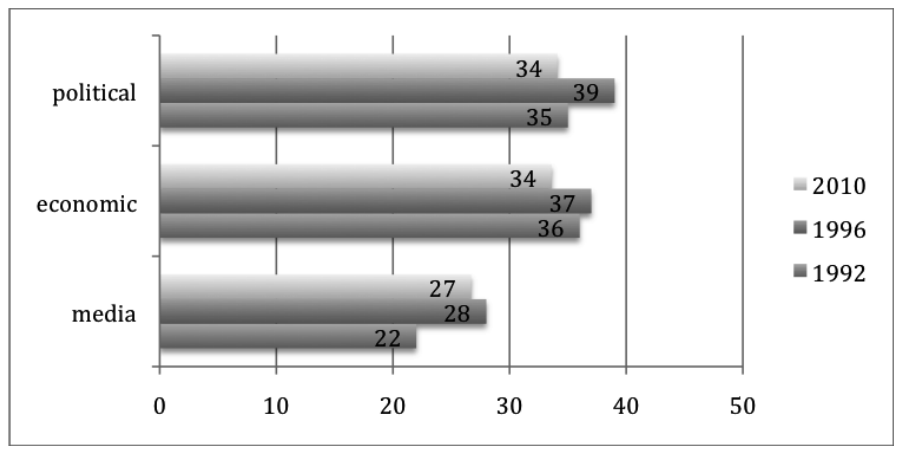

The data for the rejection of domestic antisemitism proved even more positive (see Figure 6). All three components-political, economic, and media-related-increased considerably to reach the level of relative majorities.

Figure 6: Rejection of domestic antisemitism: political, economic, media-related (percentage disagreeing with antisemitic opinions; respondents aged over 18)

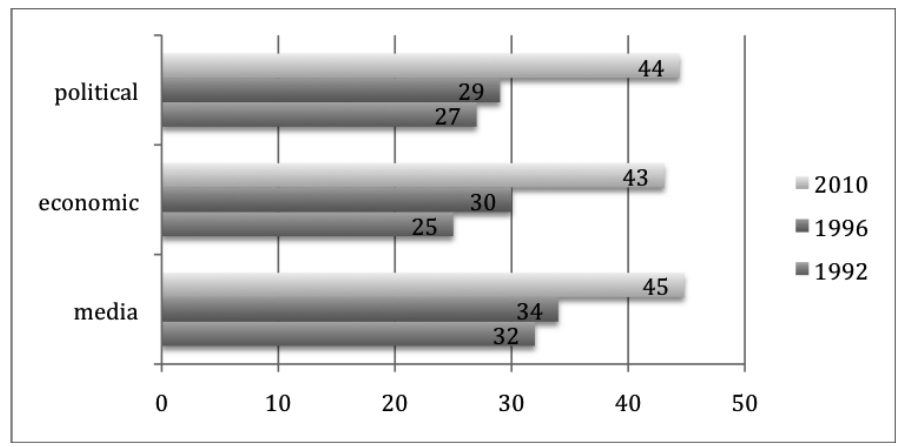

All in all, Poles in 2010 proved to be less antisemitic and more negative about antisemitism than ever before. What is not encouraging, however, is that about one-third of the adult population of Poland still holds antisemitic opinions, including one-fifth who are strongly antisemitic.

4. Who are Polish antisemites and anti-antisemites?

An important research question was what socio-demographic categories of people in Poland adhere to antisemitic opinions. It was also interesting to see which categories in particular reject antisemitism.

From the results that could be expected given the previous research, two are particularly worth discussing. They concern the relationship of antisemitism to gender and age.

Gender influences antisemitism and anti-antisemitism. In the case of modern antisemitism, more men than women agree with antisemitic opinions, but more men than 
women also declare their rejection of those opinions. In the case of religious antisemitism, the opposite is true: women are both more in favor and more against than men, although the differences are smaller than in the case of modern antisemitism. One might therefore conclude that gender relates to whether or not one shares antisemitic opinions rather than to what particular antisemitic opinions one shares.

Age also has an impact on antisemitism (and anti-antisemitism). Generally speaking, the older the respondents are, the more antisemitic they prove to be. Also, the younger the respondents, the more negative they are about antisemitism. This concerns all kinds of antisemitism: modern, religious, and post-Holocaust. The differences are usually fairly substantial. In the 2010 survey, for example, there were almost twice as many strong modern antisemites in the oldest cohort of respondents, aged 60 years or above, than among the 20 to 29 -year-olds (28.1 percent v. 15.7 percent). The earlier surveys revealed similar differences. But anomalies also occur. In the 2010 survey, for example, there were more strong modern antisemites in the youngest cohort, of 15 to 19-year-olds, than among 20 to 29 -year-olds (17.7 percent v. 15.7 percent). However, another research project that I carried out in 2005 among students aged 12-17 prior to their visit to the Auschwitz-Birkenau Memorial and Museum proved the general tendency: antisemitism in this youngest group ever to be surveyed was minimal (see Table 1).

Table 1: Modern antisemitism among Polish adults and youth (adults: from 18 years of age; youth: 12-17 years of age)

\begin{tabular}{|l|c|c|c|c|c|c|}
\hline \multicolumn{1}{|c|}{ Scale } & Adults & $\mathbf{1 9 9 2}$ & Adults & $\mathbf{2 0 0 2}$ & Youth & $\mathbf{2 0 0 5}$ \\
\hline & Frequency & $\%$ & Frequency & $\%$ & Frequency & $\%$ \\
\hline 0 (none) & 386 & 38.2 & 355 & 32.4 & 646 & 66.1 \\
1 & 233 & 23.0 & 198 & 18.0 & 175 & 17.9 \\
2 & 87 & 8.6 & 93 & 8.5 & 55 & 5.6 \\
3 & 137 & 13.6 & 154 & 14.0 & 54 & 5.5 \\
4 (strong) & 168 & 16.6 & 298 & 27.1 & 47 & 4.8 \\
\hline Total & 1,011 & 100.0 & 1,098 & 100.0 & 977 & 100.0 \\
\hline
\end{tabular}

Sources: Krzemiński (1996); Krzemiński (2004); and Kucia (2007).

The differentiation in antisemitism according to age from the least antisemitic younger cohorts to more antisemitic older cohorts that featured in the surveys in 1992, 1996, 2002, and 2010 and the low levels of antisemitism in the youngest cohorts in 2005 generate a series of questions. If the earlier research reveals such low levels of antisemitism among the young, why does the later research show higher antisemitism after the young have grown older? Is antisemitism a developmental characteristic? To what extent is it agedependent? What factors of a socio-economic nature influence the growth of antisemitism in the course of life? The surveys show that antisemitism correlates with selfassessment of one's own economic situation: the less one is satisfied, the more one is antisemitic. The qualitative research reveals that people who feel that they have little influence on or little participation in political life are more antisemitic than others. To what extent do these economic and political deprivations, which are after all age-related, explain higher antisemitism among older cohorts? In order to answer these questions further research is necessary. 
Alongside the expected but nevertheless puzzling results, the survey also produced several unexpected outcomes. Two of them are particularly important. The first concerns the relationship between antisemitism and education; the second concerns regional differentiation in antisemitism.

In regard to education, the survey showed that there are comparatively many supporters of antisemitic opinions among those Poles with a higher education or still in education. Although the level of strong modern antisemitism among those who have studied at university is the lowest among all education groups (18.5 percent $v$. an average of 21.4 percent), one might expect an even lower result. At the same time, the respondents with higher education show more domestic political and media-related antisemitism and international antisemitism than the average. Students of upper secondary schools (ages 16-18) exhibit less strong modern antisemitism than the average (19 percent v. 21.4 percent), yet one might expect an even lower result given the many Jewish history, Holocaust, and tolerance educational programs that are taught in Polish schools. Thus education does not eradicate antisemitic stereotypes, but merely helps to decrease them slightly.

The most interesting finding of the survey concerned the regional differentiation in antisemitism. As far as the various components of modern antisemitism are concerned, Poland is composed of four parts: (1) the most antisemitic provinces of eastern Poland Podkarpackie, ${ }^{7}$ followed by Podlaskie, but not Lubelskie, another eastern province; (2) the moderately antisemitic provinces of central Poland (Łódzkie, Mazowieckie, and Świętokrzyskie), southern Poland (Małopolskie, Opolskie, and Śląskie) and the eastern Lubelskie province; (3) the considerably less antisemitic western and northern areas that were granted to Poland after World War II (Dolnośląskie, Lubuskie, WarmińskoMazurskie, and Zachodniopomorskie); and (4) the least antisemitic areas of the former Prussian partition (Kujawsko-Pomorskie, Pomorskie, and Wielkopolskie). This composition does not overlap with the division of today's Poland into its former Austrian, Prussian, and Russian partitions ${ }^{8}$ that was considered important in reference to antisemitism by Krzemiński (2004). ${ }^{9}$ Antisemitism is the highest in the formerly Austrian Podkarpackie and the formerly Russian Podlaskie. The Małopolskie province, which largely belonged to Austria, is almost as antisemitic as the formerly Russian Świętokrzyskie and Łódzkie. Only formerly Prussian Wielkopolskie stands out as one of the least antisemitic. What is striking is that modern antisemitism is higher in areas where there were more Jews before World War II: first in today's eastern Poland (except for Lubelskie, which had a large Jewish population but where antisemitism is at an average level) and then in the central and southern areas. In areas where there were few Jews before

7 The Podkarpackie province is also at the top of the list in terms of religious antisemitism and post-Holocaust antisemitism.

8 In 1772, 1793, and 1795, Austria, Prussia, and Russia partitioned the Commonwealth of Poland and Lithuania. Between 1795 and 1918, Poland did not exist as a state. The territory of today's Poland comprises vast areas of what in 1914 were the Austrian, Prussian, and Russian partitions and a part of Prussia - by 1945, the Third Reich - that was granted to Poland after World War II.

9 Krzemiński discovered the most widespread modern antisemitism in the former Austrian partition, above average modern antisemitism in the former Russian partition, and the lowest, below average modern antisemitism in the former Prussian partition (Krzemiński 2004: 95). He did not consider the areas of Germany that were granted to Poland. 
the war, antisemitism is lower: in the former Prussian partition and the territories granted to Poland after the war (except for Opolskie, where antisemitism is higher). Interestingly, there is more antisemitism in the granted territories where there were very few Jews and hardly any Poles before the war than in the former Prussian partition that formed the western provinces of pre-war Poland, with few Jews and a mixed Polish and German population. The long-term impact of the regional differentiation in the number of Jews and their share in the population of a given area on today's antisemitism in this area may be interpreted through the socio-culturally inherited memory of Polish-Jewish relations, stereotypes, and prejudices. If this is true, it is amazing how long-lasting the bad memories, negative stereotypes, and prejudices are!

The number and proportion of Jews before the war, the memory of Polish-Jewish relations, and the inherited stereotypes and prejudices seem to be the most important factors in the regional differentiation in antisemitism in Poland and Polish antisemitism in general. These factors do not, however, explain the peculiarities and anomalies of the regional differentiation in antisemitism. Two non-regular cases are worth discussing: the peculiarity of the western and northern provinces and the anomaly of the Lubelskie province. It is also worthwhile analyzing the case of the Podkarpackie province, where the factors identified as key issues coincided with others and produced the highest antisemitism of all kinds in the country.

The western and northern areas of today's Poland have antisemitism below the country's average but higher than in the neighboring provinces of the former Prussian partition, where it is the lowest. The western and northern territories belonged to Germany and were granted to Poland in compensation for its war losses and the loss of its pre-war eastern areas to Russia. Before the war, there were few Jews and almost no Poles there. After the war, the remaining Germans were expelled and Poles from eastern and central Poland moved in. Given the fact that the migrants were coming from the areas of the densest Jewish settlement in Poland before the war, one might expect an average or above average amount of antisemitism, if the hypothesis of the socio-cultural inheritance of bad experiences, negative stereotypes, and prejudices were to be applied. However, the below average level of antisemitism of the first, second, and third generation of Polish migrants to the western and northern provinces illustrates how much migration and a new environment weaken the socio-cultural transmission of bad experiences and negative stereotypes.

The Lubelskie province, one of the three eastern provinces of the country that share many socio-economic characteristics, ${ }^{10}$ has antisemitism at the average level, like the central and southern provinces. There are several factors that appear to explain the positive anomaly of Lubelskie, as qualitative research has shown (e.g., the abovementioned focus group in Lublin, the capital city of the province). First and most importantly, the province's religious leader, Archbishop Życiński, is a strong denouncer of antisemitism. He has condemned antisemitic statements by politicians and the media, including Catholic ones. On a more positive note, he ordered the inclusion of teaching on Judaism and Jewish history in the curriculum of seminaries. Following his example, priests-to-be, priests, and lay Catholics participate in rituals to commemorate the local

10 The three provinces are predominantly rural and economically underdeveloped, with poor infrastructure, low levels of education level, and high level of religion and conservatism. 
Jews who perished in the Holocaust. The rituals involve reading psalms in Jewish cemeteries and (at the site of) synagogues. Second, local enthusiasts, mostly devout lay Catholics, have established and developed non-governmental organizations whose objective is to preserve Jewish heritage. The best known is "Brama Grodzka" in the city of Lublin, but there are many similar organizations in the former shtetlekh of the Lubelskie province. Third, the Catholic University of Lublin, the only university of its kind in the country, at which Cardinal Wojtyła taught before he became Pope John Paul II and of which Archbishop Życiński is Great Chancellor, has contributed to greater levels of education among regional elites. Fourth, apart from receiving many school groups from the region to visit the site of the former extermination camps - the annihilation centers for the Jews of the area - the Majdanek Memorial and Museum and its Bełżec branch offer various kinds of educational programs to teachers and the young. The impact of these and other factors have resulted in a lower level of modern antisemitism than elsewhere in eastern Poland.

The Podkarpackie province is the most antisemitic area of Poland from all perspectives. Before the war, this area had a sizeable Jewish community that constituted a large proportion of its entire population. This facilitated the development of bad experiences, negative stereotypes, and prejudices that flourished, in particular, at times of severe economic hardship. During the 40 years of Communist rule, when Poles did not have much influence on politics, the inhabitants of the Podkarpackie province felt particularly alienated, as the agrarian parties that had represented them before the war were banned and their predominantly peasant social background did not qualify them to join the Communist Party. This alienation was fostered by the stereotype of żydokomuna-the opinion that the Jews ruled the Communist Party and had imposed communism in Poland. Today, the inherited antisemitic stereotypes and prejudices are sustained and developed through a combination of various factors, as qualitative research has shown (e.g., the focus group in Rzeszów, the capital city of the province). These factors include a relatively low assessment of one's own economic situation and a perpetual feeling of little or no influence on politics. ${ }^{11}$ However, the most important influences prove to be those of the conservative clergy, particularly the leader of the local church, Archbishop Michalik, and of the extreme nationalist and often overtly antisemitic media outlets of Father Rydzyk - the Nasz Dziennik newspaper, Radio Maryja, and Trwam television.

\section{Qualitative results}

As a key component of the qualitative research, the participants of the focus group interviews were requested to comment on the survey questions that measured various kinds of antisemitism and, in particular, to elaborate on the concept of "Jew" in those questions. ${ }^{12}$ Here are the most striking of their comments.

The "Jews in our country..." were understood as: "Polish-language politicians," "Polish-language Jews who rule the country," and "Poles who have Jewish roots"

11 The Law and Justice Party of Jarosław Kaczyński, which has been very popular in Podkarpackie, lost the 2007 elections, and President Lech Kaczyński perished in an aircraft crash on April 10, 2010. The ruling Civic Platform and its presidential candidate, now President Komorowski, were perceived as alien.

12 The members of the focus groups were of course not informed that the survey measured antisemitism. 
(Rzeszów). It was felt that the word "politicians" in power in Poland is synonymous with the word "Jews." The adjective "Polish-language" was meant to downgrade the person concerned as barely Polish-speaking and even non-Polish.

The "Jews [who] have too much influence in the world" were considered to be: "Jewish upper class," "Jewish oligarchs," "not ordinary Jewish people," and "Jews in banks in America" (Rzeszów).

The statement of religious antisemitism, "Jews have so many troubles because God punished them for the crucifixion of Christ," evoked a comment that shows that modern and religious kinds of antisemitism are related:

Yes, Jews do not have their land. They did crucify Christ and said "his blood on us and on our offspring." ... And really, there are Jews all around the world and therefore they have influence on the politics of the whole world. (Rzeszów)

The same religious antisemitic statement resulted in a quick and unanimous reply from the entire group in Kraków: “No! This is a heresy!” This group, although not fully free from modern antisemitism, proved to have internalized the teaching of the Second Vatican Council and the Polish Pope on religious antisemitism.

The opinion that entailed post-Holocaust antisemitism, "it is good that as an effect of the Holocaust there are hardly any Jews in Poland," was rejected by all groups. Asked why, a Kraków participant said: "Jews are humans and therefore one cannot say it is good that they perished." A woman from the Rzeszów group commented: "John Paul II taught us that Jews are our elder brethren in faith." Yet elsewhere during the interview the same person stated: "Poland was Jewish before the war. If the Jews had not perished at Auschwitz and at other annihilation camps, we would have still been under the influence of Jewry."

\section{CONCLUSIONS}

There is a considerable amount of antisemitism in Poland, yet less than is commonly believed. Despite the shocking antisemitic comments that one may hear in Poland, the majority of Poles are not antisemitic in any meaning of the term. There are two distinct kinds of antisemitism in Poland: (a) modern antisemitism, consisting of the belief that Jews have too much influence in Poland's politics, economy, and the media, as well as in the world; and (b) historical, including religious antisemitism, with its belief that the Jews are being punished for the crucifixion of Christ, and post-Holocaust antisemitism, expressed through the opinion that "it is good that as an effect of the Holocaust there are hardly any Jews in the country." Antisemitism is differentiated according to various variables, with regional differentiation being the most interesting, as it reveals the impact of such factors as Jewish settlement before the war, socially inherited memories, stereotypes and prejudices, migration, and the positive or negative role of religious leaders and the Catholic media. The results of the 2010 research show a decline in all kinds of antisemitism and an increase in anti-antisemitism. Let us hope that one day there will be no antisemitic Poles at all. 


\section{REFERENCES}

Anti-Defamation League (2009), Attitudes Toward Jews in Seven European Countries, February 2009, prepared by First International Resources, LLC, available at: $<$ http:// www.adl.org/Public\%20ADL\%20Anti-Semitism\%20Presentation\%20February\%20 2009\%20_3_.pdf> (last visited August 18, 2010).

Datner-Śpiewak, Helena (1996), "Struktura i wyznaczniki postaw antysemickich" [The structure and indicators of antisemitic attitudes] in Ireneusz Krzemiński (ed.), Czy Polacy sa antysemitami? [Are Poles antisemitic?], Warszawa: Oficyna Naukowa.

Datner, Helena (1997), "Żydzi i Polacy w opiniach społeczeństwa" [Jews and Poles in the opinions of society], BS/3/3/97, Warszawa: CBOS.

Krzemiński, Ireneusz (1993), "Antisemitism in Today's Poland: Research Hypotheses," Patterns of Prejudice 27(1): 127-35.

(ed.) (1996), Czy Polacy sa antysemitami? [Are Poles antisemitic?] Warszawa: Oficyna Naukowa.

(ed.) (2004), Antysemityzm w Polsce i na Ukrainie [Antisemitism in Poland and Ukraine], Warszawa: Wydawnictwo Naukowe Scholar.

Kucia, Marek (2001a), "KL Auschwitz in the Social Consciousness of Contemporary Poles," Pro Memoria 15, June 2001.

(2001b), "Auschwitz in the Perception of Polish Pupils," Pro Memoria 16, December 2001.

___ (2005), Auschwitz jako fakt społeczny [Auschwitz as a social fact], Kraków: Universitas.

- (2007), "Auschwitz Concentration Camp in the Perception of Polish Students," Pro Memoria 27, June 2007. 



\title{
Anti-Jewish "Propaganda" in Brazil under Dutch Occupation
}

\author{
Daniela Levy*
}

From 1580 to 1640, Portugal went through a period known as the Iberian Union. During this time, the King of Spain governed Portugal. Due to the establishment of repressive policies by King Felipe II of Spain against Holland, which had recently declared independence from the Spanish crown, the commercial relationship between the Dutch and the Portuguese was damaged. Up to this point, Portugal had depended on Holland's financial and technical assistance in the refining and trading of its share of Brazilian sugar production. After Felipe II ordered the confiscation of all Dutch ships anchored at port in his dominions across Europe, Africa, Asia, and America, the Dutch West India Company, in an attempt to minimize the losses caused by this crisis, decided to find a way to obtain sugar directly from the northeastern region of Brazil. ${ }^{1}$

The Dutch tried to occupy Brazil twice, in 1624 and 1630. They were unsuccessful in their first attempt (Luso-Brazilian troops defeated the Dutch after a year), but in 1630 they succeeded and occupied a large part of northeastern Brazil, where they remained for 24 years. $^{2}$

At the time of the occupation, Brazil was quite cosmopolitan, with multiple ethnic groups and cultures coexisting. Jews, eager to find a refuge in Brazil, arrived from countries such as Portugal, Spain, Poland, France, and England. They moved to Brazil hoping for freedom. They were eager to find a place to live, a community where neither their place of birth nor their religion would be a reason to marginalize them or treat them as pariahs. Additionally, Jews from Amsterdam already engaged in trade with the Dutch envisioned increased opportunities for financial growth in the newly-conquered

* Researcher, Laboratory for Studies on Intolerance, University of Sao Paulo.

1 The Dutch West India Company was an enterprise of Dutch merchants founded in 1602 using both State and private capital. Its purpose was to expand Dutch economic power in America through the conquest of land and the accumulation of capital. The company's many shareholders provided the financial capital to equip its ships. The company's fleet and maintenance costs were jointly accounted, and investors received dividends in the form of profit per share based on the overall results of the company, thereby diluting the risks of each individual voyage. It was based on the same model established by the Dutch East India Company that operated in the Orient. Both companies integrated capital, armed force, and decision making power, dividing the risks and the profits in proportion to each individual investment.

2 The Dutch conquered the regions of Pernambuco, Maranhão, Rio Grande do Norte, Paraíba, and Sergipe. Some areas were recaptured by Luso-Brazilian defense militias shortly after and others remained under Dutch occupation until 1654. 
territories. Soon after they arrived in Pernambuco, the Portuguese-Dutch Jews established a community similar to the Sephardic orthodox community of Amsterdam.

During the 24-year Dutch occupation, Pernambuco experienced an extremely prosperous period, both culturally and materially. The religious tolerance that Holland extended across the northeast of Brazil created an opportunity for scientific research, literary production, and artistic creation to flourish. The Jews engaged in intense intellectual activity under Dutch rule in Brazil and were able to build a synagogue, schools, and welfare agencies. ${ }^{3}$

Jewish scholars, poets, and writers lived in Dutch Recife. They included the famed calligrapher Yehuda Machabeu and the rabbis Mosseh Rafael d'Aguillar and Isaac Aboab da Fonseca, both of whom wrote treatises in defense of equality among men.

Daniel Levy, also known as Don Miguel de Barrios, a Portuguese from Holland, wrote poems based on the lives of Jews in the Brazilian colony. He dedicated a poem to an esteemed member of the Jewish community of Dutch Recife, Abraham Cohen. ${ }^{4}$

As businessmen, the Jews played an important role in the establishment of new Dutch commercial enterprises in Brazil. This was mainly because the Sephardim, who arrived directly from Amsterdam, were familiar with both the Portuguese and Dutch languages, a fact that made them indispensable. ${ }^{5}$

The directors of the Dutch West India Company indeed had a material interest in favoring religious coexistence, but the cultural diversity of the population in northeastern Brazil did not always result in harmony between Catholics, Protestants, and Jews.

Several documents from this period show that the various ethnic and religious groups did not always live together peacefully. Portuguese and Dutch chroniclers expressed antagonism, particularly against the Jews, their way of life, and their activities.

The historiography of this period frequently stresses the religious tolerance and freedom that the Jews enjoyed in Recife. However, it is important to understand the social reality that caused conflict between Jews, Christians, and Calvinists. "Tolerance" was mandatory according to the Dutch West India Company, but competition among businessmen and merchants led to disagreements.

During this period, Manoel Calado do Salvador, a Catholic friar who belonged to the Congregation of Serra d'Ossa of the Order of Saint Paul, expressed intense antisemitic feelings. In his book, entitled $O$ Valoroso Lucidero e o Trinfo da Liberdade, written during the guerrilla war between Luso-Brazilian and Dutch troops (1645-1648), he described the city of Recife as "a true paradise before the arrival of the heretic Jews." He accused the Jews of illicit gains, corruption, and rape, as well as other defamations of character. He wrote that the Jews transformed "Recife into a Sodom and Gomorrah."

Calado attacked Jews and New Christians (conversos) in many ways. One of his main accusations was the fact that some New Christians, along with the newly-arrived Jews from Holland, were trying to build a Jewish congregation. Since the New Christians were all baptized, they were deemed Catholic heretics as soon as they returned to Judaism and were circumcised.

3 See Arnald Wiznitzar, Os Judeus no Brasil Colonial, Ed. Pioneira, Sao Paulo, 1966, pp. 55-67; Charles Boxer, Os Holandeses no Brasil, 1624-1654, Sao Paulo, Cia. Editora nacional, 1961.

4 Rabino Y. David Weitman, Bandeirantes Espirituais do Brasil-séc. XVII, Ed. Mayaanot, 2003, pp. 132-297.

5 The Jewish community of Amsterdam was formed at the end of the 16th century by Portuguese refugees from the Inquisition. 
Calado also condemned the dissimulating character of the New Christians. He wrote that they were betraying Portugal, as many seized the opportunity to return to old Jewish traditions, associating themselves with the Amsterdam Jews to obtain economic advantages. ${ }^{6}$ The Catholic friar made it known that, in his opinion, the New Christians and Jews were getting rich very fast and without effort, becoming sugar mill owners and profiting from the best opportunities in the region. ${ }^{7}$

The Christian merchants accused the Jews and New Christians of greed, with the knowledge that their ability to speak both Dutch and Portuguese helped them in their commercial enterprises. ${ }^{8}$ Friar Calado took advantage of these complaints and transformed his sermons into diatribes against the Jews. ${ }^{9}$

At this point, the old stereotypes and anti-Jewish myths that had existed since medieval times took root in Pernambuco; accusations of corruption and fraud gave Jews a bad reputation that did not correspond to reality.

After 1645, the Luso-Brazilian militia reorganized and began to exercise leadership in the fight to regain control over the Dutch occupiers. In August, a ship laden with cargo belonging to Dutch merchants and three Jews left Itamaracá island for Recife and sunk near Pau Amarelo, a region that had been conquered by the militia. Four merchants were arrested and sent to Bahia. One Jew managed to escape, but the other two Jewish merchants were held and later sentenced to death by hanging. As baptized Christians, they were given the right to receive Christian instruction before being executed. It is at this point that the stigmas of heresy and treason became confused. They were to die for treason to the homeland (collaborating with the Dutch). However, they would also die as Christians. Manuel Calado had been granted the mission to "remove the blindness by which the Jews led their lives." He was overjoyed because, according to him, he was able to confuse the Jews and eventually made them declare themselves to be happy in the belief that their souls would be saved by Jesus who, in his mercy, would take them out of the hell they were living. Of course, in the end, they were both hanged. ${ }^{10}$

Over many years, several historians leveled accusations against the Jews as traitors and collaborators with the Dutch. However, by the end of the 1970s, research conducted by Anita Novinsky demonstrated that many New Christians remained loyal to the Portuguese in the war to repossess the territory. There are many examples of such loyalty. Two masters of the sugar works, Diogo Lopes Ulhoa and Diogo da Serra, helped to defend the territory during the Dutch invasion of Bahia by building forts and trenches.

6 Some New Christians submitted themselves to circumcision when they returned to Judaism. Among them were Gaspar Francisco do Costa, Baltazar da Fonseca and his son Vasco Fernandes Brandão, and his sons Miguel Rodrigues Mendes, Simão do Vale Fonseca and Simão Drago. See Padre Manuel Calado, O Valoroso Lucideno e o Triunfo da Liberdade, Vol. 1, Belo Horizonte, Itatiaia, Sao Paulo, EDUSP, 1987, p. 101; Wiznitzer, op. cit. n. 3, at p. 51.

7 Calado, op. cit. n. 6, at p. 101: "Todavia, depois que os holandeses a ganharam (Recife), (os judeus) haviam tirado o rebuço com que andavam encobertos, e se circuncidaram, e declarara por judeus publicamente, e estes tinham muitas fazendas de raiz na terra, mancomunaram-se uns com os outros, e prevaleceram e se fizeram senhor de engenho ... e apoderando-se do melhor da terra ... se circuncidaram com grande escândalo do povo cristão...."

8 Ibid., at p. 117.

9 Ibid., at p. 48.

10 Padre Manuel Calado, O Valoroso Lucideno e o Triunfo da Liberdade, Vol. 2, Belo Horizonte, Itatiaia, Sao Paulo, EDUSP, 1987, pp. 81-83. 
Others, such as Domingos Alvarez de Serpa and Matheus Lopes Franco, joined a special commission that was part of the Governor's plan to raise funds for the purpose of recovering Pernambuco from Dutch occupation. Twenty-seven of the 180 donors (15 percent) were New Christians. ${ }^{11}$

The Dutch West India Company sent Count Maurice of Nassau to Recife in 1636 to govern the new colony. The two Portuguese who received him, João Fernandes Vieira and Gaspar Dias Ferreira, both wanted to establish grounds for coexistence between the local inhabitants and the new conquerors. According to Friar Calado, when the Old Christian João Fernandes Vieira approached Maurice of Nassau, he had the noble intention of guaranteeing the safety of the inhabitants. ${ }^{12}$ On the other hand, according to Friar Calado, the New Christian Gaspar Dias Ferreira personified the stereotype of a "traitor Jew," as he was only concerned with his own interests, eager to get rich at the cost of "the inhabitants blood." In Calado's words, he saw in the "friendship with Maurice of Nassau many opportunities to become illegally rich." Calado accused him of embezzling crates of sugar that were to be offered as a gift to the Count by the masters of the sugar works. When judging the characters of João Fernandes Vieira and Gaspar Dias Ferreira, Manuel Calado explicitly took their origins into consideration. ${ }^{13}$ The Jewish collaboration with the Dutch in the conquest of northeastern Brazil is a myth, constructed with the help of Friar Manuel Calado, which was subsequently passed on to future generations by historians. ${ }^{14}$

The animosity of the Calvinists toward the Jews was mainly due to commercial competition but always came with an alleged religious pretext. Some Calvinist ideologists that had planned the conquest of northeastern Brazil supported the idea that religion should go together with arms in defense of the land granted by God. ${ }^{15}$

Constant complaints by leaders of the Dutch Reformed Church were sent to the Governor of the Dutch West India Company in annual reports. They complained about the "arrogance" of the Jews and their dishonesty in trade. They also expressed concern over the danger of mixed marriages between Jews and Christians. ${ }^{16}$

As a result of these complaints and pressure from the Calvinist clergy under Maurice of Nassau's government, the two synagogues in Recife were closed for a short period. ${ }^{17}$ They were only given permission to reopen after the Jews promised not to carry out any rituals that could be considered too "noisy," such as the religious celebrations of Simchat Torah and Purim. ${ }^{18}$

11 Anita Novinsky, A Historical Bias: The New Christians Contribution to the Dutch Invaders of Brazil (17 Century), Fifth World Congress of Jewish Studies, 1972, pp. 141-154.

12 João Fernandes Vieira subsequently became a leader of the resistance against the Dutch occupation.

13 Calado, op. cit n. 6, at p. 102.

14 The main accusation that Calado makes about the Jews is that they were traitors to the homeland. Ibid., at pp. 48 and 51.

15 José Antônio Gonsalves de Melo, Gente da Nação, Ed. Massangana, Recife, 1996, p. 205.

16 Hermann Waetjen, "A Egreja no Brasil Holandês" (The Church in Dutch Brazil), in $O$ Domínio Colonial holandês no Brasil (The Dutch Colonial Domination in Brazil), Rio de Janeiro, CEN, 1938, pp. 350-353.

17 The synagogues remained closed from January 5 to January 10, 1638.

18 During the celebration of Simchat Torah and Purim, Jews sing and dance with joy. See Wiznitzer, op. cit. n. 3, at pp 64-65. 
A report sent to the Dutch West India Company in 1641 accused the Jews of dominating the sugar trade and professing their faith in public places. The Protestant clergy and the Christian merchants both requested in their reports that Jews should be prohibited from participating in auctions and becoming civil servants or tax-collectors. ${ }^{19}$

Demands for further ostracism of the Jews were made on a continuous basis. The Protestant clergy often cited the restrictions imposed upon Jews in other countries, such as the requirement to wear a badge on their clothes, or a red hat, or a yellow insignia on their chest to identify them, in order to prevent them from cheating or robbing Christians. Perhaps the most anti-Jewish complaint of all can be found in the following words:

everyone knew of the methods used by the sons of Judah, wholied, fooled, and used false means that made competition difficult for Christians who do not resort to such treachery. ... Because of their usury practices towards farmers, they are a true plague in Brazilian lands. Brazil belongs to Christians and not the damned sons and daughters of Israel who desecrate the name of Jesus. The Israelites are not needed here; Christians are able to do what they do! ${ }^{20}$

The Dutch West India Company regarded the Jews who came from Amsterdam as important political allies, given its interest in intensifying the import and export trade. In addition, the company could not take any drastic action against them, such as agreeing to the request to exclude them from the retail business, due to the influence of its Jewish shareholders. Therefore, the only measures that were taken included prohibiting the construction of a new synagogue and imposing economic restrictions, such as the rule that two-thirds of brokers had to be Christians.

Maurice of Nassau became aware of the growing conflict. He advocated religious freedom for all inhabitants in the belief that tolerance could only benefit the Dutch government. He believed that taking a hard line against religious groups would only increase the chances of a revolt. Calvinist ministers, however, pressured him into issuing statements that were unfavorable toward Jews. ${ }^{21}$

The tolerance that Maurice of Nassau manifested was deeply appreciated by the Jewish community. In 1642, knowing that the Count had to return to Amsterdam, Jewish representatives offered him a sum of money for each year that he prolonged his term of office so that he would remain as governor in Brazil.

The concerns of the Jewish leadership in Amsterdam were borne out by the fact that a Calvinist Synod was established in Recife in 1642 by bishops from the Reformed Church. The Synod had executive and deliberative power over all matters related to the internal organization and moral behavior of the population of Dutch Brazil. They advised the government authorities to use coercive or punitive measures in those cases judged to be scandalous and deserving of censorship or punishment. Judgment and punishment were regulated by a civil court at the request of the civil or religious authorities. ${ }^{22}$

19 Ibid., at p. 64. The sugar mills (engenhos) that had been left behind by the Luso-Brazilians during the conquest of the land by the Dutch were auctioned off. At these auctions, it was possible to acquire a sugar mill at a price below its market value.

20 Waetjen, op. cit. n. 16, at pp. 350-353.

21 Wiznitzer, op. cit. n. 3, at p. 66.

22 João Henrique Santos, "A Inquisição Calvinista-O Sínodo do Brasil e os judeus no Brasil Holandês" (The Calvinist Inquisition - The Synod and the Jews in Dutch Brazil), in Angelo Faria de Assis, Nara M. C. Santana and Ronaldo S.P. Alves (eds.), Desvelando o Poder-Histórias de Estado, 
The Synod's main concerns regarding moral behavior centered on five issues: the marital situation of couples living in concubinage; prostitution; concerns relating to invocations, blasphemies, heresies, and apostasies; transgression of the Sabbath by Jews and slaves; and freedom of religion for Jews and Catholics.

Notwithstanding the installation of the Synod in Brazil in 1642, the Class Assemblies - the name given to the meetings between the Dutch colonial government and the representatives of the Reformed Church - had discussed issues related to the Jews since 1637. Repeated criticism arose in these meetings over the freedom of Jewish worship, the "scandalous" Jewish religious practices, and the unfair competition in business dealings.

In the same year that the Synod was created in Pernambuco, a new set of regulations was created for all Jews. Under these regulations, Jewish men would have been prohibited from marrying Christian women and children of mixed marriages in which the mother was Jewish would have been raised by Christian parents. However, the leaders of the Jewish community spoke to the directors of the Dutch West India Company and the resolutions of the Synod were never put into practice. ${ }^{23}$

Trials against Jews were rare. The only known case was of a Jewish woman in Paraíba, part of the territory occupied by the Dutch, who was accused of "sacrilege," in that she had spoken out against the name of "our Savior Jesus Christ and the Holy Baptism." The Synod concluded that the case was not serious and that the woman showed promise of being converted, as she had started to attend church frequently. ${ }^{24}$

A ferocious anti-Jewish attack came from a Calvinist bishop named Vicente Joaquim Soler, who rendered services to the Dutch West India Company. In several letters, he accused the Jews of "sucking the blood of the people," "stealing the Company," and benefiting from "privileges that hurt Christian merchants." 25 These letters also reveal the Calvinists' deep concerns over the increase of the Jewish population. With the continuous influx of Jews from Holland and the increase in their birth rate, they could have become the majority group in the region. ${ }^{26}$

The reconversion of many New Christians to Judaism also raised concerns in antiJewish circles. In 1641, an Escolteto (a post combining the duties of a district attorney and a police officer) by the name of Paulo Antônio Daems requested that Gaspar Francisco da Costa, a rich New Christian, be banned from trading and his assets confiscated because he had reconverted to Judaism and submitted himself to circumcision. ${ }^{27}$

Among the various demonstrations of antisemitism in Pernambuco, there is the case of a Jew, accused of blasphemy, who was tortured and killed by a mob inflamed by the speeches of priests. The Jewish community of Amsterdam, always aware of what was

Religião e Sociedade (Power Revelation-Stories about the State, Religion, and Society), Ed. Vício de Leitura, Niterói, Rio de Janeiro, 2007, pp. 107-124.

23 Ibid., at p. 121.

24 Wiznitzer, op. cit. n. 3, at p. 55.

25 Brasil Holandês: Dezessete cartas de Vicente Joaquim Soler (Dutch Brazil: Seventeen Letters of Joaquim Soler), Ed. Index, Rio de Janeiro, 1999.

26 On February 5, 1638, two ships - De Soutcas and Graeuw Paert - arrived in Recife from Amsterdam with 200 Jews, led by Manuel Mendes de Crasto (Manuel Nehemias), on board. See José Antônio Gonsalves de Melo, Gente da Nação, Ed. Massangana, Recife, 1996, p. 223.

27 Daems' duties were of an executive nature, and he also appointed judges. For several years, he was also general secretary of the government of Maurice of Nassau, having demonstrated on many occasions his aversion toward the Jewish people. 
going on in Brazil, reacted with indignation and accused the Dutch government of Recife of supporting the persecution of Jews. They also complained that the Escabinos (lay members of a mixed court) of Mauricia should have let this case be tried by the Council of Justice, as they did in Holland for cases of blasphemy. They argued that the Escabinos lacked standing to judge this matter. ${ }^{28}$

Several attempts were made to prevent Jews from practicing their religion freely. However, when the Ecclesiastic Council of the Calvinists decided that the two synagogues should be closed again, the Jewish community of Recife contacted the Council of the Elders (Sanhedrin) in Amsterdam, who wrote a petition in 1645 to request that no distinction be made between Jews and Christians in the Dutch colonies. In reply to this petition, a document entitled Patente Honrosa (Honorable Patent) was addressed to the Supreme Council of Brazil and the Governor. As a result, both synagogues remained open, and the Jews were able to continue their religious practices. ${ }^{29}$

Antisemitism flourished vigorously in the economic realm. Several episodes reveal that competition and business disagreements led to discrimination against the Jews. Moisés Abendana, a sugar trader who had debts with several Dutch creditors (amounting to 12 florins), was found hanged under mysterious circumstances. The authorities concluded that he had committed suicide. The Council chamber of the Escabinos, led by Escolteto Daems, forbade his burial and determined that his body be displayed hanging as an example of the dishonesty of the Jews. The Jewish community leaders of Recife went to Governor Maurice of Nassau to defend the honor of Abendana, claiming that he was a victim of murder. In an attempt to avoid humiliation, they offered to pay Abendana's debt plus a bonus for the inconvenience created by the incident. When the Governor declined their offer, they went directly to the creditors. On receiving the money, the creditors allowed the burial to take place. ${ }^{30}$

The Portuguese continually tried to reconquer the lost territory, and in 1645 the LusoBrazilians organized an insurrection. The Dutch reinforced their defenses while simultaneously becoming stricter in religious matters. Jews were accused of not respecting the Sabbath by working and opening their schools. Christians began to insult Jews in the street. ${ }^{31}$

The period of the Dutch occupation of Brazil in the 17th century was one of the few times when Jewish life flourished at this time in history. However, it only lasted for a short period, and it cannot be said that it was entirely free of anti-Jewish feeling. In 1654, when the Dutch were forced to leave Brazil, the relative freedom of the Jews ended. ${ }^{32}$ The Jews left with the Dutch, only to experience new difficulties in the Caribbean and back in Amsterdam.

28 de Melo, op. cit. n. 26, at p. 269. The Council of the Escabinos was a chamber of magistrates, the position of judge was an elected office, and any person was eligible. The chamber was presided over by an Escolteto.

29 de Melo, op. cit n. 26, at p. 254.

30 Wiznitzer, op. cit. n. 3, at p. 76; Santos, op. cit. n. 22, at pp. 120-122.

31 de Melo, op. cit n. 26, at p. 305.

32 In 1648, the Dutch experienced the beginning of their defeat in Brazil, when their territories were reduced to the shores of Pernambuco. A big battle in proximity to Recife, in Guararapes, marked the end of the Dutch occupation in Brazil. At the beginning of 1654, the war between Dutch and Portuguese troops ended with a capitulation agreement according to which the Dutch would have three months to leave the area. See Jacob R. Marcus, The Colonial American Jew, Vol. 1, Wayne State University Press, Detroit, 1970, p. 209. 


\section{BIBLIOGRAPHY}

Bauer, Yehuda, "Anti-semitism as a European and world problem," in Patterns of Prejudice, Vol. 27, London, Institute of Jewish Affairs, 1993.

Brasil Holandês: Dezessete cartas de Vicente Joaquim Soler, Ed. Index, Rio de Janeiro, 1999. Boxer, Charles, Os Holandeses no Brasil, 1624-1654, Sao Paulo, Cia. Editora Nacional, 1961.

Callado, Padre Manuel, O Valoroso Lucideno e o Triunfo da Liberdade, Belo Horizonte, Itatiaia, Sao Paulo, EDUSP, 1987.

Carneiro, Maria Luiza, Preconceito racial em Portugal e Brasil Colônia-Os cristãos novos eo mito da pureza de sangue, 2nd ed., Ed. Perspectiva, Sao Paulo, 2005.

Feitler, Bruno, "A circulação de obras antijudaicas e Antisemitas no Brasil colonial," in Maria Luiza Tucci Carneiro (ed.), O Anti-semitismo nas Americas, Ed. Edusp., Sao Paulo, 2007.

Gorenstein, Lina and Maria Luiza Tucci Carneiro (eds.), Ensaios sobre a IntolerânciaInquisição, Marranismo e Anti-semitismo, 2nd ed., Ed. Humanitas/LEI, Sao Paulo, 2005. Israel, Jonathan I., Radical Enlightenment: Philosophy and the Making of Modernity 16501750, Oxford University Press, London, 2001.

Levy, Daniela Tonello, Judeus e marranos no Brasil Holandês - Pioneiros na colonização de Nova York (século XVII), Master's dissertation, University of Sao Paulo, 2008.

Marcus, Jacob R., The Colonial American Jew, Vol. 1, Wayne State University Press, Detroit, 1970.

Melo, José Antônio Gonsalves de, Gente da Nação, Ed. Massangana, Recife, 1996.

Nazario, Luiz, Auto de Fé como Espetáculos de Massa, Associação Editorial Humanitas, Sao Paulo, 2005.

Novinsky, Anita, A Historical Bias: The New Christians' Contribution to the Dutch Invaders of Brazil (17th Century), Fifth World Congress of Jewish Studies, 1972.

Poliakóv, Léon, De Maomé aos Marranos, 2nd ed., Ed. Perspectiva, 1996.

Santos, João Henrique, "A Inquisição Calvinista-O Sínodo do Brasil e os judeus no Brasil Holandês," in Angelo Faria de Assis, Nara M.C. Santana and Ronaldo S.P. Alves (eds.), Desvelando o Poder - Histórias de Estado, Religião e Sociedade, Ed. Vício de Leitura, Niterói, Rio de Janeiro, 2007.

Waetjen, Hermann, "A Egreja no Brasil Holandês," in O Domínio Colonial holandês no Brasil, Rio de Janeiro, CEN, 1938.

Wiznitzar, Arnold, Os Judeus no Brasil Colonial, Ed. Pioneira, Sao Paulo, 1966. 


\title{
Antisemitism According to Victor Klemperer
}

\author{
Miriam Oelsner*
}

\begin{abstract}
People of Abraham, fighting against obstacles of all kinds are working their way upwards to humanity. ${ }^{1}$
\end{abstract}

\section{INTRODUCTION}

... Nazism permeated the flesh and blood of the people through single words, idioms and sentence structures which were imposed on them in a million repetitions and taken on board mechanically and unconsciously. Words can be like tiny doses of arsenic: they are swallowed unnoticed, appear to have no effect, and then after a little time the toxic reaction sets in after all. ${ }^{2}$

Victor Klemperer (1881-1960) was born in Germany to a Jewish family and later became an outstanding specialist of French literature. ${ }^{3}$ As a full professor of Latin letters at Dresden Technical University from 1920, he had strong ties to the works of Montesquieu, Voltaire, and Diderot. He was impregnated with the "illuminist" way of thinking, and his free-faculty thesis was about Montesquieu, under the advisement of Karl Vossler, dean of Munich University. ${ }^{4}$ Klemperer spent the early years of his career in Munich, where one of his colleagues, also advised by Vossler, was another famous Latinist, Erich Auerbach, the author of Mimesis.

The importance of speaking about Victor Klemperer in the context of antisemitism relates to his analysis of the totalitarian Nazi regime, after he and his wife spent the twelve years of terror in Germany. It has to be said that this analysis was essentially oriented toward language, since Klemperer had discovered that language was a very powerful weapon used by the Nazi terror. The Nazis manipulated language with the general purpose of embedding the Nazi ideology and the particular purpose of disseminating antisemitism among the German people.

So, what is this analysis? Why did Klemperer and his wife stay in Germany instead of leaving the country as most Jews did? To answer these questions, it is important to know more about him.

* University of Sao Paulo.

1 Published about the Jewish Emancipation in the German magazine Sulamith in 1811.

2 Victor Klemperer, The Language of the Third Reich: LTI, Lingua Tertii Imperii: A Philologist's Notebook, translated by Martin Brady (London, Continuum 2002) p. 15 (hereinafter, LTI).

3 According to the Brockhaus Encyclopedia of 1925.

4 Vossler was a contemporary of the Italian philosopher, historian, and politician Benedetto Croce, with whom he maintained close cultural contact. 


\section{About Victor Klemperer}

Klemperer was a true representative of the dream of so many Jews, ever since the Jewish Emancipation was promoted in Germany by Moses Mendelssohn at the end of the 18th century, to be accepted by the German society.

This had also been the dream of his parents, for whom he was the ninth and last child. As emigrants from the Prague ghetto, they settled down in Breslau, now Wroclaw (Poland), where his father, Wilhelm Klemperer, earned a doctorate in Jewish philosophy and theology. He became a rabbi, initially in small communities and ultimately at the Reformist Synagogue in Berlin. It is therefore not entirely surprising that three of his four sons converted to Lutheranism, taking into account that the Reformist ritual was relatively close to Lutheranism. His four daughters did not have enough autonomy for attitudes of this kind. Nevertheless, Klemperer's mother is known to have been fairly advanced for her times as far as her Bildung (cultural education) was concerned. The whole family had the burning wish to be a part of the German society. They craved a kind of Jewish-German syncretism, associated with the concept of Bildung expressed by the German Jewish poets and writers Heinrich Heine (1797-1856) and Berthold Auerbach (1812-1882). According to George Lachmann Mosse (1918-2001), the German Jews' search for Bildung was related to a search for a personal identity beyond the boundaries of religion and nationality. ${ }^{5}$

The new ways of thinking about and organizing society represented a rupture with the traditional Jewish concept of a "nation in exile," insofar as they would make it possible to include the Jews in the German nation. Berthold Auerbach used to say that "the old religious life started from Revelation, whereas the new one would start from Bildung."

Victor Klemperer had a strong connection to the spirit of the French Revolution, the Century of Lights, and the ideas of liberté, égalite, fraternité, which led his professional life toward the Latin letters, of which he became a full professor at the University of Dresden in 1920. He lost this position in 1935 upon the advent of the anti-Jewish Nuremberg Laws. Given his domestic environment, which was devoted to modernity and primarily oriented toward the aforementioned concept of Bildung, Klemperer avoided any contact with National Socialism, with its retrograde and racist mentality. He saw it as an exogenous epidemic that would be unable to survive in "his" Germany. Nazism was a perfect combination of a diabolical rationality at the service of the utmost irrationality.

National Socialism grew stronger and stronger before people's very eyes, at the same time as it promoted the full-scale destruction of the incipient yet already decadent Weimar Republic. A great part of the German population did not accept the Weimar Republic, as they were nostalgic for the power of the Empire and the assumed protection of the Kaiser. Even after reading Adolf Hitler's Mein Kampf, Klemperer was unable to believe that "his" Germany would let itself be infected by the virus of fascist totalitarianism. In his posthumous book Geschichte eines Deutschen, ${ }^{6}$ Sebastian Haffner explains that it was inevitable that some false messiahs would appear at the height of German hyperp. 2.

5 George L. Mosse, German Jews Beyond Judaism (Cincinnati, Hebrew Union College Press 1985)

6 Sebastian Haffner, Geschichte eines Deutschen (A German's Story), 8th ed. (München, Deutsche Verlags Anstallt 2001). 
inflation. Hitler was only one of them. That explains why he was initially not taken seriously when Mein Kampf, the only book he ever wrote, was published in 1925, exposing his racist and antisemitic way of thinking.

The foundations of nationalist, racist, and totalitarian thinking aimed at preserving the "purity of Northern Aryan blood" against the "Jewish Bolshevist democratic internationalism" date back to this period, which marked the beginning of the struggle between the Übermensch (the Aryan) and the Untermensch (the inferior Jew).

Klemperer and his wife Eva Schlemmer, a Lutheran pianist, chose not to leave Germany despite the increasing Nazi influence. A great number of university professors joined Hitlerism. Klemperer's professional environment became extremely dark. His brother George, a famous doctor, and his cousin Otto, the famous maestro, emigrated from Germany to the United States in the early 1930s, while Victor Klemperer was eventually forced into confinement at Dresden during the twelve years of terror from 1933 to 1945 . He was first allowed to stay in his home, but from 1940 onward he had to stay in one of the three well-known Judenhäuser (Jews' houses). He stayed there until February 1945, when Dresden was bombed by the Allies, which miraculously and paradoxically made it easier for the Klemperers to escape. They therefore survived the Shoah, just like his "Diaries," which had been hidden thanks to his wife's courage. She had entrusted them for safekeeping to the equally brave Dr. Annemarie Köhler, a doctor with whom they were friends.

According to Peter Gay, Klemperer is one of the most important German diarists. His notes on the Nazi period are one of the fundamental documents of the testimonial literature, as Elie Wiesel described it. In the immediate aftermath of the war, he was asked by a Dresden editor to publish them, yet he chose to write a new book in which he would present testimony on everything he had experienced from the viewpoint of the professor, the educator, the sociopolitical analyst, the philologist, the etymologist, the historian, the thinker, the philosopher, the Jew persecuted by racism, and, finally, the "survivor." Klemperer was aware of the fact that this book would be the first step in his attempt to understand what this terrible, malignant phenomenon called Nazism had been. His basic question was whether the roots of Nazism could have been truly German, as shown by his analysis in Chapter 21: "German Roots" of the book.

He also wondered about the role of fanaticism and the fundamental role played by the Jews with regard to Nazism, as he explains in Chapter 26: "The Jewish War":

The Jew is the most important person in Hitler's state: he is the best known Turk's head of folk history and the popular scapegoat, the most plausible adversary, the most obvious common denominator, the most likely brackets around the most diverse of factors. Had the Führer really achieved his aim of exterminating all the Jews, he would have had to invent new ones, because without the Jewish devil - "anyone who doesn't know the Jew doesn't know the devil" - without the swarthy Jew, there would never have been the radiant figure of the Nordic Teuton. ${ }^{7}$

Klemperer's "Diaries" were only published after the fall of the Berlin Wall in 1995.

The book Klemperer published in Berlin in 1947, LTI-Lingua Tertii Imperii: Notizbuch eines Philologen, based on his "Diaries" written during the Nazi period, attracted little

7 Klemperer, LTI, supra note 2, at p. 274. 
interest. The survivors were concerned with finding food and getting a roof over their heads, as well as with finding their scattered relatives and retrieving their former jobs. But there was actually much more at stake. Nobody wanted to hear about the atrocities that had been committed, let alone in the form of a book. Everybody wanted to hide from the facts and deny their participation.

There were people who came to Klemperer to ask him for a letter stating that they had not taken part in anything, so that they could regain their place in society. He refused them all. If everybody denied their participation in the whole tragedy, then who had been the executioners?

Had he only published his "Diaries," there would have been even less interest. While he was writing them, he never knew if he would still be alive the next day. Most of the people who belonged to Klemperer and his wife's circle succumbed, either in the extermination camps or by suicide. Klemperer's "Diaries" are among the most tragic books ever written. Besides hunger, illnesses, deportations, and murders, they show the cynicism and cruelty of the Nazi regime toward the Jews, the few remaining opponents of the regime, and some Catholic priests. It is frightening. There were cases, for instance, when the authorities sent an explanation for the death of one of the inhabitants of a Judenhaus in a camp, along with a small funeral urn, stating that the cause of death was an MI (myocardial infarction). Klemperer wrote that they would even allow burials, with the recital of kaddish and a sermon, but not without countless cynical acts. As the number of deaths increased during the war, the urns were no longer sent.

\section{THE IMPORTANCE OF KLEMPERER'S NOTES}

The analysis of Nazi speech in Victor Klemperer's LTI is fundamental to our understanding of how totalitarianism is imposed on people, because it is an in-depth study of the fascist mental structure. ${ }^{8}$ It starts with an examination of how the German language was manipulated by those in power between 1933 and 1945. Many researchers of the National Socialist period have used LTI in their work, including the German writer Martin Walser (1927), the French historian Jean-Pierre Faye (1925), Professor Steve E. Aschheim of the Hebrew University of Jerusalem, ${ }^{9}$ George L. Mosse (1918-2001), Ritchie Robertson of Oxford University, Renato Lessa of Rio de Janeiro, Paola Traverso of the Free University of Berlin, and others. They all regard Klemperer as the pioneer of the study of totalitarian language. To Aschheim, for example, Hannah Arendt's Men in Dark Times would have been immeasurably enriched by Klemperer's LTI, which appeared in 1947. ${ }^{10}$ As to why this was not in fact the case, he provides the answer himself: Hannah Arendt did not know Victor Klemperer.

Anne Frank's diary and Klemperer's "Diaries" and LTI are different to other testimonial literature, because they were written outside the concentration camps. This kind of narrative presents other perspectives on the true life of Jews in an urban environment. For instance, the Klemperers were able to stay together, in contrast to most survivors of the extermination camps, who lost all their loved ones. The tragic end of Anne Frank is

8 According to the Brockhaus Encyclopedia of 1995.

9 Steve E. Aschheim, "Victor Klemperer and the Shock of Multiple Identities," Scholem, Arendt, Klemperer: Intimate Chronicles in Turbulent Times (Cincinnati, Hebrew Union College Press 2001) p. 70.

10 Ibid., p. 71. 
not in her diary. Another statement by Aschheim, quoting the work of Paola Traverso, ${ }^{11}$ argues that Klemperer's LTI and "Diaries" are read so much because they provide the reader with a happy ending, since the couple ultimately survived.

To write LTI, Klemperer deconstructed the new language of Nazism. He sensed from the beginning of the Nazi regime that the German language was undergoing a change and named it lingua tertii imperii - the language of the Third Reich. He discovered that it was a manipulated language, aimed at preventing the population from thinking for itself, as those who think do not let others manipulate them. He thus got to the heart of the language manipulation developed by Goebbels, the Nazi propaganda minister. It was a language very poor in vocabulary and content, due to the use of vulgarizing commonplaces that erased the subtleties and complexity of culture. It was meant to reduce the capacity to think and prevent critical analysis. The spoken and written language were very similar to each other, always formulated in a declamatory, artificial, and easily memorized style, devoid of any ethics. While working on this mental impoverishment, Goebbels also targeted the innermost essence of any human being: faith. He went to great efforts to influence people to surrender - body and soul - to the totalitarian regime that would provide them with all they might need by worshipping Hitler, the Führer. Goebbels used every available method to convince the population, including the Nazi party's newspaper, radio broadcasts, speeches, military exhibitions, and parades, as well as the terror of constant murders and arrests - a diabolical combination of seduction and coercion.

Whether or not the roots of Nazism are typically German is another question that permeates the entire book. Klemperer considers this issue at length. Irrationalism leads to the destruction of reason. It is the perfect combination of a diabolic rationality at the service of the utmost irrationality. In Chapter 21: "German Roots," he indulges in blunt auto-criticism:

How was the terrible disparity possible between contemporary Germany and every single period of Germany's past? I had always found the traits éternels, the abiding features of a national character of which the French speak, to be born out in practice, or at least that's what I believed, and I had always stressed them in my own work. Was it all wrong? Was there any intellectual connection between the Germans of the Age of Goethe and the people who supported Adolf Hitler? ${ }^{12}$

\section{GERMAN ANTISEMITISM}

With the rise of the Bavarian Illuminati in the late 18th and early 19th century, more and more demonstrations of antisemitism began to occur in Germany. After the Napoleonic wars and those conducted by Bismarck, after poor crops and other adverse events in the German economy, antisemitism gained currency. The Jews had entered the labor market, the universities, and the most cultivated and competitive circles of society. By the end of the 19th century, the German antisemitic party was founded. Heinrich von Treitschke, a prestigious history professor at the University of Berlin, a prominent

11 Paolo Traverso, “Victor Klemperers Deutschlandbild - Ein jüdisches Tagebuch?" in Deutschlandbilder: Tel-Aviv Jahrbuch für Deutsche Geschichte, Vol. 26 (1997) pp. 307-44.

12 Ibid., p. 129. 
antisemite, and the author of the famous sentence "die Juden sind unser Unglück" (the Jews are our misfortune), was a major disseminator of antisemitism. In 1893, the Centralverein Deutscher Staatsbürger Jüdischen Glaubens, a Jewish association for the defense of the Jews' civil rights, was founded in Berlin, and braches were later established in several other German cities. During its entire existence, until the Kristallnacht of November 1938, the members of the Centralverein were able to have more than 500 people arrested for having committed antisemitic acts. The strengthening of antisemitism, the rise of ultra-rightist parties, and exacerbated nationalism all began after Germany lost World War I. The confluence of all these negative factors deserves a whole separate study.

Klemperer's importance has grown in the years leading up to the 50th anniversary of his death in 1960. In August 2010, a conference entitled "Le langage totalitaire d'hier à aujourd'hui. En hommage à Victor Klemperer" was held in his honor in Normandy (France), in the presence of the renowned historian Jean-Pierre Faye, the author of Totalitarian Languages and other works.

\section{THE EUPHEMISMS}

Much has already been written about the euphemisms created by the senior hierarchy of the Nazi regime. Klemperer exposed many of these half-truths. He wrote not only about these euphemisms but also about the ability to generate preconceptions, create stigmas, and turn into normal what is abnormal and inhuman. In LTI, for example, he analyses the stigma created by the obligation for Jews to add the names "Sara" or "Israel" to their names, the stigma of the "yellow star," which isolated the Jews from the rest of the population, the boycott against Jewish businesses, and the cities "sanitized" of Jews, with signs announcing that a particular place, park bench, or building was judenrein (Jew-free). Klemperer comments on how the population started to see this procedure as "normal." Persons who were unaware of his Jewish origins came to him to declare the "disgust" they felt for Jews.

Klemperer's notes on euphemisms and paraphrases give his book a special significance. In recognition of that fact, Professor Hannes Heer of Hamburg University produced Im Herzen der Finsternis (In the Heart of Darkness), a book in which eleven professors comment on interesting paraphrases noted by Klemperer and quoted by those who studied his work. In this book, the authors make special mention of the comments of Professor David Bankier, who was also a Klemperer scholar.

After the fall of the Berlin Wall, all the literature of the former DDR (German Democratic Republic) surfaced. This included Klemperer's two books, which caused an actual frenzy upon their (re)launch. During a visit to Sao Paulo in 2002, David Bankier, then Director of the Yad Vashem International Research Institute, explained that people wanted to read Klemperer because he mentioned all those who helped him and his wife. This is in addition to the fact that, as Leopold von Ranke wrote, he told everything as it actually happened ("wie es eigentlich gewesen").

George Steiner, ${ }^{13}$ another linguist, wrote the following about Victor Klemperer's LTI:

13 George Steiner, "The Hollow Miracle," Language and Silence: Essays on Language, Literature, and the Inhuman, 10th ed., translated by Gilda Stuart and Felipe Rajabally (Sao Paulo, Cia. das Letras 1988) p. 134. 
The [Nazi] language no longer stimulates thinking, but confuses it. Instead of charging each expression with the greatest available energy and lack of circumlocutions, it loosens and disperses the intensity of sentiment. The language ceases to be an adventure (and a living language is the greatest adventure the human brain is capable of). In summary, the language is no longer experienced; it is only spoken.

As I republish this essay, I do it also because I believe in the validity of its argument. When I wrote it, I did not know Victor Klemperer's remarkable book "Notes of a philologist", published in East Berlin in 1947. ... In a much more detailed way than I did, Klemperer, a professional linguist, outlines the submission of German to the Nazi slang and the linguistic-historical priors of this submission.

\section{FINAL CONSIDERATIONS}

After the Nazi experience, Klemperer's attitude changed. He realized that he had also been a German with a feeling of national superiority. As he used to say, he believed in the traits éternels (eternal features) of each people. However, experiencing and surviving racial prejudice showed him how wrong this was. 



\title{
Antisemitic Anti-Zionism Within the German Left-Die Linke
}

\author{
Sebastian Voigt*
}

\section{INTRODUCTION}

This essay analyzes the antisemitic anti-Zionism of the radical left in Germany and focuses mainly on the far left party Die Linke. ${ }^{1}$ For several years, Die Linke has played an increasingly large role within the German political spectrum. The party was founded in 2007 as a result of the fusion of two other parties: the successor of the Eastern German Communist Party (SED) and the Election Alternative for Social Justice (WASG), a group of disgruntled social democrats and labor unionists who had split from the moderate left-wing Social Democratic Party (SPD). Currently, Die Linke is a hodgepodge of different, sometimes contradictory political ideologies ranging from orthodox Stalinists to moderate reformers. The evolution and composition of the party is thus hard to predict. Still, one thing is certain: Die Linke has become a major player in German politics and has a strong influence on the European left in general. In Germany's last parliamentary elections in 2009, it gained 12 percent of the vote. In addition, it is the fourth strongest party in the Bundestag - Germany's federal parliament. Several of its members hold seats in the European Parliament. At the present, it is the most important party in the European Left, an association of leftist parties in the European Union. ${ }^{2}$ Die Linke is represented in 13 of Germany's 16 state parliaments and is part of the governing coalitions in two states, including Berlin. In elections held during the past two years, Die Linke increased its share of the vote to 28 percent in the Eastern states of Germany (former GDR) and to an impressive 20 percent in some Western parts of Germany. This information is crucial to understanding the relevance of the following analysis.

\section{OVERVIEW OF KEY DEVELOPMENTS WITHIN THE GERMAN LEFT SINCE REUNIFICATION: THE EMERGENCE OF A LEFTIST PRO-ISRAEL POSITION}

Recently, a small but audible segment of the German left has started to consider criticism of antisemitism - and equally of anti-Zionism and anti-Americanism - as central to

* Simon Dubnow Institute for Jewish History and Culture at the University of Leipzig. I wish to thank Ursula Duba for helping me with the subtleties of the English language.

1 See the English version of the homepage of Die Linke, available at: <http://die-linke.de/ politik/international/english_pages> (last visited September 30, 2010). See also Dan Hough, Michael Koss and Jonathan Olsen, The Left Party in Contemporary German Politics (Basingstoke: Palgrave Macmillan, 2007).

2 See: <http://www.european-left.org> (last visited September 30, 2010). 
the renewal of a progressive view of modern society. This includes support of Israel, which is in direct opposition to the position of the mainstream left. ${ }^{3}$

The emergence of a pro-Israel left is connected to developments in German society since reunification in 1990. The debate within the left should be regarded as a result of the profound political changes that took place at this time. Reunification was seen by many leftists as a reversal of the outcome of the Second World War. The reunification of Germany coincided with a wave of pogroms and racist attacks against foreigners, asylum seekers, and Jews. This led to fears of a "Fourth Reich" and the re-emergence of German imperialism. In retrospect, these fears were completely unfounded. Nevertheless, they were a direct consequence of a decisive rupture in German and European history. The decline of the Soviet Union and the end of the Cold War caused the world view of many leftists to collapse, even if they had never supported Soviet-style communism. The apparent victory of capitalism and of liberal democracy turned the established ideology of leftist thinking on its head and caused a fundamental disorientation.

At the time, a debate about the history of the left and its mistakes slowly started to emerge, and a small segment of the German left began to deal self-critically with antiZionism, anti-imperialism, and its relationship with the State of Israel. Several leftist magazines even supported the second Gulf War in 1990-1991. ${ }^{4}$ More members of the left supported the war against the Taliban after $9 / 11$, and some unexpectedly supported the overthrow of Saddam Hussein's dictatorship in Iraq in $2003 .{ }^{5}$

\section{THE BAK SHALOM GROUP}

These changes within left-leaning groups did not fundamentally affect Die Linke until 2007, when a group called BAK Shalom was founded with the purpose of exposing and combating antisemitism, anti-Zionism, anti-Americanism, and what was described as regressive anticapitalism within Die Linke. ${ }^{6}$

3 On this trend, see the recent article by Jeffrey Herf, "Fresh Air in Central Europe," The New Republic (August 2010). The article is available online at: <http://www.tnr.com/blog/foreignpolicy/77228/fresh-air-in-central-europe > (last visited September 29, 2010). A good summary of the historical genesis of this pro-Israel leftist position can be found in an interview with the Austrian researcher and Stop-the-Bomb activist Stephan Grigat: "Communism, anti-German criticism and Israel. An interview with Stephan Grigat by Jens Misera," first published in Israel Nachrichten (the German daily newspaper in Tel Aviv) in 2004, first published in English at: <http://info.interactivist. net $>$ in 2005, available at: <http://www.cafecritique.priv.at/interviewIN. html > (last visited September 29, 2010).

4 The most important leftist magazine at this time was (and still is) konkret, which featured a long and difficult debate about the Second Gulf War. Some authors supported the war, which led to the loss of half the readership. See the homepage of konkret at: <http://www.konkret-verlage.de/ $\mathrm{kvv} / \mathrm{kvv} \cdot \mathrm{php}>$ (last visited September 29, 2010). There was also an extensive debate in the left in general. See, for example, Klaus Schönberger and Claus Köstler, Der freie Westen, der vernünftige Krieg, seine linken Liebhaber und ihr okzidentaler Rassismus oder wie die Herrschaft der neuen Weltordnung in den Köpfen begann (Grafenau: Trotzdem-Verlag, 1992).

5 The most important book on this discussion is Jihad und Judenhass by Matthias Küntzel. The book was also translated into English. See Matthias Küntzel, Jihad and Jew-Hatred: Islamism, Nazism, and the Roots of 9/11 (New York: Telos Press Publishing, 2007).

6 See the English version of the declaration of principles by BAK Shalom, available at: <http:// bak-shalom.de/index.php/english> (last visited September 29, 2010). 
Although I have never been a member of Die Linke, I have been in touch with many of its members. In addition, I once received a scholarship from the Rosa-LuxemburgFoundation, which is closely linked to Die Linke. ${ }^{7}$ I was myself a founding member of $B A K$ Shalom and have written articles and given talks about antisemitism and antiAmericanism. As a result, I was accused of being an agent of imperialism and called a Zionist traitor and a neo-liberal racist. Nevertheless, BAK Shalom managed to make this discussion, which had been going on for several years, a part of the overall framework of Die Linke. BAK Shalom received considerable media attention and for some time I was so optimistic that I believed it might be possible to substantially influence the political discourse within Die Linke. ${ }^{8}$ Unfortunately this was not to be. I was obviously too optimistic or may have been too naive - as I was often told from the very outset. ${ }^{9}$

\section{THE CORE IDEOLOGY OF DIE LINKE}

The predominant fundamentalist ideology of Die Linke is anti-imperialist, adamantly opposed to the existence of Israel, and both overtly and covertly antisemitic. The most recent evidence of this ideology was revealed during the confrontation on the Mavi Marmara on May 31, 2010, when a commando of the Israeli Defense Forces stormed the ship after the captain refused to comply with the instructions of the Israeli navy. Nine people were killed in the ensuing struggle. Two current and one former member of the German Bundestag were on board the Mavi Marmara. All are members of Die Linke: Norman Paech, Annette Groth, and Inge Höger. They were arrested by the Israeli army but were released shortly thereafter.

It is noteworthy to look at what happened when they returned to Germany. They were not taken to task by Die Linke for cooperating with an organization with suspected terrorist links. Neither did they have to justify their support for radical Islamists who are well known to be reactionary to the very core and blatantly trample on the most basic human rights - especially women's rights. Instead, the chairwoman of Die Linke, Gesine Lötzsch, expressed pride in their so-called mission. ${ }^{10}$ The only voice from within Die Linke that criticized the actions of her colleagues was Petra Pau, vice-president of the German parliament. ${ }^{11}$ She subsequently faced a storm of criticism from within Die Linke.

7 See the English version of the homepage of the Rosa Luxemburg Foundation: <http://www. rosalux.de/english/foundation.html $>$ (last visited September 29, 2010).

8 Members of BAK Shalom have published several articles in important newspapers. See Sebastian Voigt and Benjamin Krüger, "Let the Left Go Forward," Jerusalem Post, December 9, 2009, available at: <http://www.forum-ds.de/article/1385.let_the_left_go_forward.html>; or Sebastian Voigt, "An Israels Seite," Der Tagesspiegel, May 5, 2008, available at: <http://www.tagesspiegel.de/ meinung/kommentare/an-israels-seite/1237002.html> (last visited September 29, 2010).

9 A discussion between Jan Gerber and this author was published in the German leftist weekly Jungle World. See Sebastian Voigt, "Sich jetzt endlich einmischen," and Jan Gerber, "Austreten, aber schnell," Jungle World 23, June 5, 2008, available at: <http://jungle-world.com/artikel/2008/23/21943. html > and <http://jungle-world.com/artikel/2008/23/21944.html > (last visited September 29, 2010).

10 See the newspaper article by Miriam Hollstein and Thomas Vitzthum, "Wir sind stolz auf Ihren Einsatz," Welt Online, June 2, 2010, available at: <http://www.welt.de/die-welt/politik/article 7879320/Wir-sind-stolz-auf-Ihren-Einsatz.html> (last visited September 29, 2010).

11 Petra Pau wrote an open letter to the Jewish Community in Bremen and criticized the members of Die Linke who were on board the ship. See: <http://www.swr.de/report/-/id=6636856/ property=download/nid=233454/mvqbrq/index.pdf $>$ (last visited September 29, 2010). 
The above-mentioned three politicians referred to themselves as "survivors of the Israeli massacre" and went on a propaganda tour of various German cities in order to tell the story of their heroism firsthand. During one of those events, Norman Paech, a former member of parliament and retired professor of law, went so far as to suggest that the next Gaza freedom flotilla should be accompanied by the German maritime forces that patrol the Lebanese border. If this request were to be carried out, it would amount to using the German military against Israel. The audience roared loudly in response to this suggestion, and one member of the audience was so fired up that he expressed his desire to hit the fascist State of Israel next time. Norman Paech called that "an idea." ${ }^{12}$ It needs to be emphasized that this scandalous response was made by a former member of the German parliament and former foreign policy expert of a legitimate German party that is represented in the Bundestag.

Alas, statements like these are merely the culmination of a process that has been in the works for some time. In 2006, for example, Wolfgang Gehrcke, a member of the Bundestag for Die Linke, wanted to invite representatives of Hamas to a conference. However, they were denied entry visas to Germany. ${ }^{13}$ Many members of Die Linke regard Hamas as the legitimate, democratically elected government of the Palestinians. The organization's ideology and highly undemocratic structure does not raise a red flag within Die Linke, which conveniently ignores the virulent antisemitism of Hamas.

During the Lebanon War in 2006, Christine Buchholz, a hardcore member of Die Linke and currently a member of the Bundestag, referred to Israel and the United States as warmongering countries, adding: "Hezbollah represents, along with the peace movement in Israel and the international antiwar movement, the opposite side in the conflict. This is also the side that I am on."14 Buchholz then went on to describe the "demonization" of Hezbollah as one of the most egregious prejudices expressed by the media during the war. For a politician of the left to say that she sides with a terrorist organization such as Hezbollah is almost beyond belief, but it also constitutes irrefutable proof of a very crucial shift in leftist politics and ideology.

\section{THE UNDERLYING REASONS FOR THE LEFT'S HATRED OF ISRAEL}

There are several explanations for the left's bottomless hatred of Israel. One key factor is anti-imperialism, which is informed by a dichotomous view of the world. According to

12 This "event" was recorded by radio journalists of the independent station Freies Sender Kombinat (FSK) in Hamburg. Afterwards, they produced a 60-minute radio program entitled: Wie antisemitisch ist die Linkspartei? (How antisemitic is the Left Party?). The program can be listened to online at: <http://www.freie-radios.net/portal/content.php?id=35000> (last visited September 29, 2010).

13 See Ulrich W. Sahm, "Nahostkonferenz im Berliner Reichstag: Hamas-Sprecher erhält kein deutsches Visum," haGalil.com, October 23, 2006, available at: <http://www.hagalil.com/01/de/index. php?itemid=23> (last visited September 29, 2010).

14 The quote in German is: "Auf der anderen Seite stehen in diesem Konflikt die Hisbollah, die Friedensbewegung in Israel und die internationale Antikriegsbewegung. Das ist die Seite, auf der auch ich stehe." Interview with Christine Buchholz by Rüdiger Göbel, "Im Krieg muss sich die Linke positionieren. Die Dämonisierung der Hisbollah ist Teil der Kriegsführung," Junge Welt, August 15, 2008. It is available online at: <http://www.achse-des-friedens.de/aktionen_lk05.htm> (last visited September 29, 2010). 
this world view, the world and society are split into two opposing groups: one group wants peace and the other group wants to pursue imperialism. In other words, there is an exploiting First World and an exploited Third World. This is as simplistic a concept of the complexity of modern societies as one could possibly imagine. It inevitably leads to the personification of social relations, which makes it easy to pinpoint the persons responsible for exploitation and oppression. This encourages all those who refuse to use knowledge and rationality to understand the complex world we live in to entertain wild conspiracy theories. On the basis of old, deeply entrenched prejudices, Jews are perceived as those pulling the strings, while Israel is seen as the spearhead of Western imperialism in the Middle East and as an artificial state that is a foreign object in the organic body of Arab societies. ${ }^{15}$

\section{ORTHODOX COMMUNIST IDEOLOGY}

The anti-Israel ideology of Die Linke has two roots. The first one is the communist ideology and politics of the German Democratic Republic (GDR). The GDR was not an antisemitic country per se, although it mounted several anti-Zionist campaigns that made ample use of antisemitic stereotypes. The so-called Merker trial in the mid 1950s, during which Paul Merker and other leading members of the Communist Party were convicted of having collaborated with Israel and the United States - the imperialistic archenemies - is but one example. The GDR considered itself to be an anti-fascist state and engaged in the self-righteous self-deception of having eliminated the roots of fascism by nationalizing heavy industry and expropriating the reactionary Prussian landowners. ${ }^{16}$ The hegemonic notion of fascism in the GDR stemmed from the orthodox communist view, as expressed by Georgi Dimitrov in the mid 1930s. Fascism in power, he said, is "the open terrorist dictatorship of the most reactionary, most chauvinistic, and most imperialist elements of finance capital."17

If fascism is regarded as the supreme form of capitalistic dictatorship, the antisemitic ideology has to be put on the back burner. Antisemitism was not recognized as the core of Nazi ideology but as a means of distraction employed by the ruling class to divide the proletariat. Auschwitz and the annihilation of the European Jews was not recognized as a rupture in civilization itself, as Dan Diner has pointed out. ${ }^{18}$ In the communist coun-

15 Moishe Postone has written extensively about antisemitism and the relationship between anti-Zionism and antisemitism. See his famous essay Moishe Postone, "Anti-Semitism and National Socialism: Notes on the German Reaction to 'Holocaust,'" New German Critique 19 (Winter 1980), pp. 97-115. See also the recent interview with Postone by Martin Thomas, "Zionism, anti-semitism and the left," February 5, 2010, available at: <http://www.workersliberty.org/story/2010/02/05/zionismanti-semitism-and-left $>$ (last visited September 29, 2010).

16 See the monumental work by Jeffrey Herf, Divided Memory: The Nazi Past in the Two Germanys (Cambridge, MA: Harvard University Press, 1997), pp. 69-105.

17 Georgi Dimitrov, The Fascist Offensive and the Tasks of the Communist International in the Struggle of the Working Class against Fascism. Main report delivered at the Seventh World Congress of the Communist International, August 2, 1935, available at: $<$ http://www.marxists.org/reference/archive/ dimitrov/works/1935/08_02.htm> (last visited September 29, 2010). See also Thomas Haury, Antisemitismus von links. Kommunistische Ideologie, Nationalismus und Antizionismus in der frühen DDR (Hamburg: Hamburger Edition, 2002), pp. 293-455.

18 Dan Diner (ed.), Zivilisationsbruch. Denken nach Auschwitz (Frankfurt a.M.: Fischer Verlag, 1996). 
tries of Eastern Europe, Jews were not acknowledged as a distinct group of victims. Instead, communists and antifascist resistance fighters were the most important people to be memorialized. As a result of this delusion, adequate research of the Holocaust never took place. In addition, the GDR did not see any reason to normalize relations with Israel and rejected all claims for compensation by Holocaust survivors. After 1945, the continued existence of antisemitism, which was very much alive in a large part of the population, was never addressed or dealt with because-according to the ideology of orthodox communism - the socialist nations were seen as the true winners of history bringing progress to the world.

Besides the historical context of the Cold War and the strong relations between the Soviet bloc and the Arab states, this ideology played a major role in explaining the undiluted ferocity of anti-Zionism and the enduring comparison and equation of Israel with Nazi Germany in the GDR. This was not a legitimate form of political criticism but a fierce form of antisemitic anti-Zionism. ${ }^{19}$ To this day, this pernicious hatred of Israel deriving from orthodox communist ideology is alive and well in a large part of Die Linke.

\section{THE ANTI-ZIONISM OF THE WEST GERMAN LEFT}

The other justification of hatred of Israel in Die Linke is to be found in the history of the radical left in West Germany. Its relations with Israel differs from those of the GDR. Until the Six-Day War, the majority of leftists in West Germany had a pro-Israel attitude. However, the tremendous historical shift that followed this decisive war unleashed a fierce hatred of the Jewish state, which in turn became an integral part of the left's identity. This hatred has all the attributes of a pathological aversion. Israel was no longer regarded as a socialist experiment, with its kibbutzim and its egalitarian ethos, but as a country of oppressors - by no one less than the recent murderous persecutors of the Jews. It was henceforth referred to as a racist, occupying power that deprived the Palestinians of their human rights and their national homeland. ${ }^{20}$

This hostility toward Israel can only be understood in the context of the widespread romanticization of revolution itself. Since Western democracies had given up on revolutions and since the proletariat that was supposed to be the carrier of the revolutionary banner was ignorant of its historical obligation, the longing for a revolution had to be transferred to the Third World. The ideology of tiermondisme was on the rise, and the left began to support all kinds of national liberation movements in the Third World as a redirection activity, an alternative for what was missing under their very own noses. Some groups even supported the Khmer Rouge in Cambodia, but the Palestinians became the main object of solidarity. Their terror attacks were justified as the actions of an oppressed underdog fighting a powerful enemy. The Palestinians fitted neatly into the leftist cult of the noble guerrilla. Leftist radical groups like the Rote Armee Fraktion even received military training in Palestinian camps. Leftist West German groups went so far as to commit antisemitic crimes. On November 9, 1969, the thirty-first anniversary

19 See Sebastian Voigt, "Das Verhältnis der DDR zu Israel," in Bundeszentrale für politische Bildung (ed.), Dossier 60 Jahre Israel, May 2008, available at: <http://www.bpb.de/themen/XEBFIJ,0,0, Das_Verh\%E4ltnis_der_DDR_zu_Israel.html> (last visited September 30, 2010).

${ }_{20}$ See Martin W. Kloke, Israel und die deutsche Linke. Zur Geschichte eines schwierigen Verhältnisses (Frankfurt a.M.: Haag + Herchen, 1994), pp. 65-81. 
of the Night of Pogroms (Kristallnacht) of 1938, a group called Tupamaros West-Berlin planted a bomb in front of the Jewish Community Center in Berlin and justified this attack as a necessary response to the so-called "fascist" crimes of the Zionists and as an expression of solidarity with the fighting fedayeen as the avant-garde of worldwide revolution. ${ }^{21}$

\section{SECONDARY ANTISEMITISM}

In addition to the above-mentioned explanations, it is obvious that neither East nor West Germany can be compared to other countries. When all is said and done, the fact remains that contemporary Germany is the successor to Nazi Germany. Thus, another feature has to be added to the leftist hostility toward Israel in order to explain this particular brand of anti-Zionist antisemitism. ${ }^{22}$

After 1945, the official expression of traditional antisemitism became taboo in both Germanys. Unofficially, however, antisemitism was expressed both overtly and covertly without restraint. In the following decades, the ever-present antisemitic resentment had to find a different venue to express itself. After the Holocaust, every Jew personified the crimes committed by Nazi Germany. Jews were perceived as an obstacle to the development of a national identity and a positive identification with Germany and its history. Jews were seen as permanent accusers who perpetuated Germany's bad conscience and exploited German guilt by demanding reparations. This antisemitism is perfectly expressed in the following paradoxical statement: the Germans will never forgive the Jews for Auschwitz. ${ }^{23}$ This bizarre and twisted thinking eventually resulted in the externalization of German guilt. Nazis were consequently seen everywhere, but most specifically in Israel. In due course, Jews were - and continue to be-accused of having learned nothing from the Holocaust and acting like Nazis. On the other hand, Palestinians are regarded as the new Jews, the victims of the former victims. By demonizing and "Nazifying" Israel and opposing its existence, German leftists are able to construct an anti-fascist continuity for themselves and fight the anti-fascist battle that their Nazi parents and grandparents never fought.

The advantage of this secondary antisemitism to German leftists can be observed on an individual, psychological level (in West Germany) as well as on a collective level (in East Germany). The defamation of Israel as a fascist country and Zionism as a fascist ideology conveniently strengthens the anti-fascist self-deception. Because antisemitism was never recognized for the core evil that it was, and because fascism was merely seen as a different kind of capitalistic oppression, the Holocaust was not recognized as the

21 See Wolfgang Kraushaar, Die Bombe im jüdischen Gemeindehaus (Hamburg: Hamburger Edition, 2005).

22 See Lars Rensmann, Kritische Theorie über den Antisemitismus: Studien zu Struktur, Erklärungspotential und Aktualität (Hamburg: Argument Verlag, 2001), pp. 231-287. See also Samuel Salzborn, Antisemitismus als negative Leitidee der Moderne: Sozialwissenschaftliche Theorien im Vergleich (Frankfurt a.M.: Campus Verlag, 2010), pp. 317-342.

23 This is how the Journalist Henryk M. Broder put it. See Henryk M. Broder, Der Ewige Antisemit. Über Sinn und Funktion eines beständigen Gefühls (Frankfurt a.M.: Fischer Verlag, 1986), p. 125. See also Andrei S. Markovits, "A New (or Perhaps Revived) 'Uninhibitedness' toward Jews in Germany," Jewish Political Studies Review 18:1-2 (Spring 2006), available at: <http://www.jcpa.org/ phas/phas-markovits-s06.htm> (last visited September 30, 2010). 
worst genocide ever committed in the history of all of humanity and consequently lost its abominable horror.

The most common example of current manifestations of secondary antisemitism is anti-Zionism. Although these ideologies are not identical, they overlap to a large extent. According to Léon Poliakov, Israel has become the Jew among the nations; it serves as the collective Jew. ${ }^{24}$ This antisemitic anti-Zionism is not exclusive to the German left but expresses itself in Germany in a highly unadulterated form.

\section{IGNORANCE ABOUT IDEOLOGY AND THE INFORMAL LEFTIST-JIHADIST}

\section{ALLIANCE}

Ignorance concerning the destructive power of ideologies seems to be a particular blind spot of the leftist world view. This critical blind spot is repeated in the leftist attitude toward Islamism. It is also evident in Die Linke and has grown in significance during the past few years. In previous decades, the German left supported various so-called national liberation movements but mainly secular ones. It supported the PLO and the PFLP but nowadays supports Hamas - a fanatically religious and oppressive organization.

This development was recently labeled the leftist-jihadist "Querfront" (cross-front) by the German Journalist, Ivo Bozic. ${ }^{25}$ Some parts of Die Linke openly proclaim their collaboration with radical Islamic groups against the United States and Israel. Asked how they could have cooperated with radical Islamic organizations and fascist groups, the parliamentarian members of Die Linke either claimed that they did not know who had organized the Gaza freedom flotilla or baldly denied that fascist or Islamist groups had indeed participated. Under a highly benign interpretation, one might consider such behavior naive. However, it is much more probable that these collaborators with radical Islamists know exactly what they are doing.

A certain convergence of orthodox leftist and Islamist ideology is obvious. Both share an anti-imperialist ideology, a deep hatred of Israel and the United States, and a dystopian yearning for a simple, pre-modern world. Both ideologies also reject globalization and financial capital as a symbol of the exploitative capitalist society. Both tend to simplify the complexity of the modern world into a clear-cut, black and white paradigm without shades of gray. Both feel morally superior and self-righteous and delude themselves in thinking that they are fighting for a higher cause and that they are always on the side of the global underdog and the oppressed masses. At the global level, the leftist-jihadist collaboration manifests itself in the alliance of Venezuela and Iran: the self-proclaimed socialist paradise of the twenty-first century and the reactionary dictatorship of the mullahs.

\section{CONCLUSION}

Die Linke cannot and must not be dismissed as an irrelevant radical fringe on the left of the German political spectrum. That would be the height of irresponsibility. Because it

24 On the relationship between anti-Zionism and antisemitism, see Léon Poliakov, Vom Antizionismus zum Antisemitismus (Freiburg: ça ira Verlag, 1992).

25 See Ivo Bozic, “Die Entstehung der Mavi-Marmara-Linken," Jungle World 31, August 5, 2010, available at: <http://jungle-world.com/artikel/2010/31/41448.html> (last visited September 30, 2010). 
does not operate under the same political restrictions as the mainstream political parties, Die Linke often expresses widespread anger and hatred toward Israel more openly than those parties. The many examples of antisemitic anti-Zionism involving politicians of all parties are shocking, ${ }^{26}$ but only parliamentary members of Die Linke could participate in the Gaza freedom flotilla and still be supported by their party leadership. In no other party is the left's ingrained hatred of Israel as rampant.

In regard to Israel and the conflict in the Middle East, Die Linke may appear to be the avant-garde of German society. I hope that this is an overly pessimistic interpretation, and I would gladly be proven wrong in this regard. Still, I fear that my presumptions are not totally over the top. This is illustrated by the following incident that took place shortly after the incident involving the Mavi Marmara, namely when the German Secretary for Development, Dirk Niebel, was refused entry into the Gaza strip by the Israeli authorities. Even though it is widely known that Israel prohibits official visits by foreign dignitaries to Gaza so as not to legitimize the Hamas government, the German Bundestag passed an unanimous resolution condemning Israel's actions, including the blockade of the Gaza Strip. ${ }^{27}$ Even conservative politicians who are in general considered to be pro-Israel praised Die Linke for its opposition to the blockade. ${ }^{28}$ This resolution serves as proof that all German political parties presented a united front against Israel. Needles to say, this new and alarming development undeniably strengthened Hamas.

Finally, it is important to note that the debate within Die Linke is not yet over and done with. ${ }^{29}$ The organization's ultimate direction will be crucial for people on the left not only in Germany but also throughout Europe.

26 For a profound analysis of antisemitism in the political culture in Germany, see Lars Rensmann, Demokratie und Judenbild. Antisemitismus in der politischen Kultur der Bundesrepublik Deutschland (Wiesbaden: Verlag für Sozialwissenschaft, 2004).

27 For the precise wording of the petition dating from June 30, 2010, see: <http://dipbt. bundestag.de/dip21/btd/17/023/1702328.pdf> (last visited September 30, 2010).

28 A parliamentarian from the conservative CDU, Philipp Missfelder, praised the hardcore leftist member of Die Linke, Wolfgang Gehrcke, for sharing common ground concerning the Gaza blockade. The original quote in German is: "Selbst wenn in der Aussendarstellung häufig der Eindruck entsteht, dass die Linkspartei grundsätzlich anderer Meinung sei, so glaube ich doch, Herr Gehrcke, dass gerade auch die Wortbeiträge, die Sie schon an verschiedenen Stellen abgegeben haben, keinen Zweifel daran lassen, dass Sie sich auf einem ähnlichen, gemeinsamen Boden befinden, wie wir das tun." See: $<$ http://philipp-missfelder.com/de/Politik/Reden/70/35_Rede_im_ Deutschen_Bundestag/artikel,535,1,1.html> (last visited September 30, 2010).

29 See Samuel Salzborn, “Die Linkspartei hat ein Antisemitismusproblem," Welt Online, June 8, 2010, available at: <http://www.welt.de/debatte/kommentare/article7957984/Die-Linkspartei-hatein-Antisemitismusproblem.html> (last visited September 30, 2010). 



\title{
Two Thousand Years of Antisemitism: From the Canonical Laws to the Present Day
}

\author{
Anita Waingort Novinsky*
}

My interest in antisemitism began during long years of studying, researching, and teaching about the Holy Office of the Inquisition and the converted Jews in Portugal and Brazil (New Christians, conversos, marranos, and anussim).

In this paper, I want to ask a question that was formulated a few years ago at a conference in Paris sponsored by the Jules Isaac Association: " "Antisémitisme-a-t-il encore aujourd'hui des racines chrétiennes?"

One of the conference participants, Alain Finkielkraut, gave a positive answer, but said that we have to understand this question considering its paradox. On the one hand, the Church is today dialoguing with the Jews, but on the other hand present-day antiJewish propaganda is repeating the old slogans and defamatory arguments against them. ${ }^{2}$ Nostra Aetate has abandoned the infamous references to "Jewish deicide" and "treacherous Jews," but if we compare the language and the vocabulary used by the present antisemites to that used in past centuries, we will still find a strong influence of the Church doctrine against the Jewish people.

Let us go back to the sources.

Reading the canonical laws and analyzing the expressions, opinions, and ideas that appear during the Church councils, we find terms like "abominable Jew," "impious people," "hard-hearted," and "unbelievers." If we decode the discourse of the language and find the hidden significance of the author's experience, we will understand that the sense and the defamation message are the same as in the 20th and 21st centuries.

During the Visigothic period (4th and 5th centuries), there was a similar phenomenon to the forced conversion of the Jews to Christianity that occurred in Portugal in 1497. A clandestine Judaism flourished for more than a century in high medieval Spain, and we can compare, in many aspects, this early marranism to crypto-Judaism in the modern era (16th to 18 th centuries). ${ }^{3}$

Izidoro (560-636), the famous Bishop of Seville, can be considered the ideologist for the discrimination against the Jews and one of the most ferocious antisemites of the

* Professor, Department of History, University of Sao Paulo.

1 L'Antisémitisme a-t-il encore aujourd'hui des Racines Chrétiennes? Nouvelle Série, No. 8, Cahier de L'Association des Amis de Jules Isaac, July 2007.

2 Ibid., at pp. 8-13.

3 On the marranos and the Inquisition in Portugal, see M. Kayserling, Historia dos Judeus em Portugal, 2nd ed. (Sao Paulo: Perspectiva 2009), translated from the original German by Gabriela B. Correa da Silva and Anita Waingort Novinsky (Geschichte des Juden in Portugal, 1867). 
Church. His statements anticipated Nazi antisemitism ${ }^{4}$ by more than a thousand years. He tried to denigrate the Jewish faith, attacking the most sacred Jewish symbols - the synagogue and the Jewish Sabbath. To the holy place of prayer, the synagogue, he gave a sexual label; the Jewish Sabbath he considered a repulsive holy day, originating from luxurious sins. ${ }^{5}$

Physically, the Jews were characterized as having a "bad smell," which was a sign of their spiritual deterioration and biological evidence of a gradual dehumanization. ${ }^{6}$

Here we find the same accusation as in Germany in the 20th century, namely that Jews were "worms" and not human beings. Baptism will not help, said the Bishop of Seville, as nothing can change the evil nature of these people, for they are all the antichrist and carry the forces of Satan. ${ }^{7}$

The accusation that Jews are not human beings may be considered the most extreme example of all the cruel designations that were imposed on the Jews. One thousand one hundred and forty years before the rise of Nazism, Izidoro, together with the high clergy, spread the idea that Jews were different creatures with a different nature and that no human reaction could be expected from such creatures. ${ }^{8}$

Canonical law prohibited intermarriage and sexual intercourse between Christians and Jews. Jews were not permitted to eat together with Christians, ${ }^{9}$ to hold public office, ${ }^{10}$ to employ Christian servants or have Christian slaves, ${ }^{11}$ or to walk in the street during Passover. ${ }^{12}$ It was ordered that the Talmud and other Jewish books should be burned, ${ }^{13}$ and Christians could not use the services of Jewish doctors (even though all Portuguese kings had Jewish doctors).

From the 13th century onward, Jews were obliged to wear a badge on their clothes ${ }^{14}$ and were forbidden to build new synagogues..$^{15}$ The Synod of Breslau (1267) imposed compulsory ghettos on the Jews ${ }^{16}$ and at the Council of Basel (1434, session XIX) they were forbidden to obtain academic degrees. ${ }^{17}$

4 "Izidore's theological anti-Judaism was translated into practical measures through the legislation of the Fourth Council of Toledo." Bat-Sheva Albert and Renata Sancovsky, Inimigos da FéJudeus, Conversos e Judaizantes na Península Ibérica. Seculo VII. (Rio de Janeiro: Imprinta 2009) p. 262, n. 586. On Isidoro de Sevilha. see Bat-Sheva Albert, "Isidore de Sevilha: His Attitude towards Judaism and His Impact in Early Medieval Canon Law," in The Jewish Quarterly Review, Vol. LXXX, Nos. 3-4 (January-April) (Philadelphia; Annenberg Research Institute 1990); Sancovsky, supra, at p. 203, n. 586.

5 Sancovsky, supra n. 4 , at pp. 275-276.

6 Ibid.

7 J. Trachtenberg, The Devil and the Jews. (New Haven: Yale University Press 1943); Sancovsky, supra n. 4 , at p. 280, n. 744.

8 Sancovsky, supra n. 4, at p. 282.

9 Synod of Elvira (306).

10 Synod of Clemont (535).

11 Third Synod of Orleans (538).

12 Ibid..

13 Twelfth Synod of Toledo (681).

14 Fourth Lateran Council (1215).

15 Council of Oxford (1222).

16 Sancovsky, supra n. 4, at p. 285.

17 Ibid., at p. 297. 
According to the Church, nothing noble could ever originate from the Jews, Christ could never have been a Jew, and not even Isaac could have given birth to the Jewish people. ${ }^{18}$

As in Germany in the 20th century, Jews were considered by canonical law as infected and the disseminators of all sickness that existed in the kingdom. Julian, Bishop of Toledo (642 AC), suggested the need for a special prophylactic against the disease spread by the Jews. Sickness was considered by the bishop as a metaphor for the malignity of the Jews. ${ }^{19}$ The kingdom was divided into healthy and infected parts, exactly as in Spain and Portugal during the inquisitorial centuries and by the Germans during Nazism.

The Visigoths developed the foundation for the future demonization of the Jews. The idea that no conversion could change them because nothing could eradicate the malignity they carried was adopted by the Inquisition in the Iberian countries. And in 1449, in Toledo, professional corporations excluded all descendants of the conversos, under the pretext of "impurity of blood" but in reality to eliminate New Christian competition. ${ }^{20}$

After having lived in the Portuguese and Spanish Empire for more than 15 centuries, Jews were declared foreigners, and there was no place for them any more. The Holy Office of the Inquisition was officially introduced in Portugal in the year 1536 by the King D. João III, solely due to the existence of converted Jews suspected of being followers of the Jewish faith. ${ }^{21}$ The Jews were the only people in the world for whom a specific court of justice was established to observe and arrest them. Historians that are not familiar with the inquisitorial documents can never be aware of the extent of the obsession against the Jewish people and the dimensions of the falsehoods spread among the Portuguese population.

The Catholic clergy was mostly responsible for the doctrine of hate that convinced the Portuguese to participate happily in the mass spectacles of burning at the stake of New Christians (marranos). ${ }^{22}$ The inquisitorial agents followed every step of the conversos and had the right to arrest them and deliver them to the Inquisition. All assets were immediately confiscated and divided between the Crown and the Church. Other heresies besides Judaism, such as sodomy, bigamy, and witchcraft, gradually also became subject to the Inquisition, but the majority of the trials were connected to cryptoJudaism.

The court of the Inquisition was a political institution that worked together with the Church. For several periods during the 17th century, the governor and the Inquisitor were the same person. Both the Church and the State acted with hypocrisy. The Inquisitors handed down the death sentences, but as the Church could not spill blood the victims were delivered to the King's functionaries, who killed them.

The portrayal of the conversos during the Visigothic period was repeated during the Inquisition and again in the 20th century. Jews were regarded as spies, traitors, and betrayers of their fatherland. If Christians were not alert, in a hundred years the Jews

18 Ibid.

19 On the situation of the Jews in Portugal, see Kayserling, supra n. 3.

20 A. Sicroff, Los Estatutos de Limpieza de Sangre (Madrid: Taurus 1958), translated by M. Arminõ.

21 Kayserling, supra n. 3.

22 L. Nazario, Autos de Fé como espetaculos de massa (Sao Paulo: Humanitas 2005). 
would occupy all the land. They were regarded as a highly dangerous group that caused a lot of harm because their main purpose was to conquer the world. The same idea was mentioned by the Protocols of the Elders of Zion, published in the Soviet Union in 1897 and still sold today.

All kinds of lies were invented in Portugal as they were during the Visigothic period. Pamphlets and posters were hung on church walls to persuade the population to take up arms against the Jews and eliminate "every Jew dog." Books were written and published against Jews and conversos in the 17th and 18th centuries in Spain, manuscripts were distributed, sermons were delivered from church pulpits to convince people that the Jews must be blamed for every calamity that had happened. During the Acts of Faith, the long sermons were not directed at the different heresies, against faith and behavior, but mainly at the "Jewish nation." We must point out that, in practice, the objective was not only the Portuguese crypto-Jewish population but all Jews as a people.

All the discriminatory measures and accusations from the canonical laws were repeated by the Inquisition in the Portuguese kingdom and later by the Nazis: the myth of pure blood (1935), the prohibition to walk in the streets on certain days (1938), the burning of Jewish books (1938), the destruction of synagogues (1938), and the prohibition of relations with Jews (1941). ${ }^{23}$

After the Holy Office of the Inquisition was abolished in Portugal (1821), the country took a new direction politically and some of the descendants of the New Christians poets, intellectuals, and writers - tried to tell the history of the previous dark centuries, with a certain degree of philosemitism. However, the majority of the Portuguese historiography ignored and erased this picture from the Portuguese landscape. It took more than a century for historians to start to research the Inquisition. Some antisemitic works appeared in Portugal at the beginning of the 20th century, and there are still authors today who try to minimize the effects and cruelty of the Holy Office.

During the three centuries of Inquisition activity involving the persecution and extermination of the New Christians, no one cared about their destiny. Not one nation protested against the genocide; not a single voice spoke out officially in favor of the miserable Portuguese Jews. The cultivated conversos, who were able to flee to Holland, wrote beautiful poetry expressing their sympathy and sorrow for the victims, in words and in tears. But besides Menashe ben Israel, who went to England to speak to Cromwell about the readmission of the Portuguese Jews, the world remained silent.

One man in Portugal, a Jesuit, who cannot be forgotten, had the courage to speak in favor of the Jews: Father Antonio Vieira. He went to Pope Innocent XI and asked him to help the innocent people who were burned at the stake in his country. Afterwards, some measures interrupted the court of the Inquisition's work for a while, but activities soon resumed, and the fire continued to burn for the unfortunate Portuguese conversos. ${ }^{24}$

There are, nevertheless, some differences between the Inquisition and Nazism that are interesting to consider. The victims of the Inquisition had a name, and the trials lasted for relatively long periods. For months, or even years, the New Christian was

23 R. Hillberg, The Destruction of European Jews. (Nova York: Holmes \& Meier Publishers 1985) pp. 5-8.

${ }^{24}$ On the defense of the Jews by Father Antonio Vieira, see A. Novinsky, "A Catholic Priest and His Fight for Justice for the Jews: Father Antonio Vieira," in Selected Essays in Jewish Studies. (Jerusalem: World Union for Jewish Studies 2009) pp. 33-39. 
called before the Inquisitorial panel. There was a genealogy; he had a family. The process had a number, but the prisoner was a human being. For the Nazis, the Jew was not human, only a number on his arm and a label on his clothes. And the end of his life was faster, in the gas chambers, compared to the hours at the stake. The Inquisition was punishing a doctrine, an idea, a "weltanschauung" - a crime. For the Nazis there was no specific crime - it was only the "Jew" - and all were guilty, as they all contaminated the soil, the body, and the soul. Even in the Edict of Expulsion of the Jews from Spain (1492), the danger of "contamination" was mentioned. In 1493, Rome was stricken by a heavy leprosy epidemic that was called Pest marranorum. Prophylactic measures were ordered to exterminate the parasites and dangerous bacilli.

At the Conference on Global Antisemitism organized by the International Association for the Study of Antisemitism at Yale University (August 23-25, 2010), I saw a video about the Arab propaganda against the Jews, and I thought how unbelievable it was that, in a changing world like ours, 1,300 years after the Christian medieval councils, we still hear the repetition of the same defamatory concepts, the same accusations, the same lies, the same demonization, and even the same vocabulary.

From the Visigothic Kingdom, via the Inquisition, to Nazism, the defamatory language remains the same, be it anti-Judaism and antisemitism or anti-Israelism and antiZionism. The significance, sense, and purpose are the same: the destruction of the Jews.

From the past to the present, new elements have been added to the old inquisitorial and Nazi antisemitism: Israel and Zionism. Even if times have changed and the historical circumstances of the world are different, there are, as the historian Ephraim E. Urbach has also pointed out, certain similarities and parallels. ${ }^{25}$

The antisemitism that was so widespread in Portugal, a country that was traditionally tolerant, and where the population coexisted amicably for centuries with the Jews, did not start with lower classes. It came from above, from the high clergy and the nobility. In Nazi Germany, the intellectuals were the first adherents of what later emerged as a genocidal regime demonstrating that the major danger to society stems from ideologies adopted by intellectuals. ${ }^{26}$

The purpose of this paper is not to explain the reason for this long hatred of the Jews, but to show that its Christian roots continued to exist in the Nazi period and similarities can still be found in modernity.

Conversion and assimilation did not help. The Inquisition investigated as far back as seven or eight generations to identify Jews. Nazism only went as far back as the third or fourth generation. The Portuguese and the Germans hated the assimilated Jews more than their orthodox coreligionists.

For Zygmund Bauman, the factors and mechanisms that made the extermination of the Jews possible during Nazism continue to exist. There are reasons to worry, because we live in the same society that made the Holocaust possible.

In the words of Umberto Eco, if the past had not provided the hate and the defamation against the Jews, the Holocaust would never have happened.

25 Ephraim E. Urbach, "Antisemitism: Historical Antecedents," in Present-Day Antisemitism (The Hebrew University of Jerusalem 1988) p. 337.

26 Franklin Littell and Yehuda Bauer, "Summary," in Present-Day Antisemitism, supra n. 25, at p. 340 . 



\section{Table of Contents of Volumes I-V}

\section{CONCEPTUAL APPROACHES}

Introduction

Charles Asher Small

"New Europe," Holocaust Memory, and Antisemitism

David M. Seymour

Antisemitism and Anti-Capitalism in the Current Economic Crisis

Nicolas Bechter

Equations in Contemporary Anti-Zionism: A Conceptual Analysis

Shalem Coulibaly

Antisemitic Metaphors and Latent Communication

Bjoern Milbradt

Economic and Behavioral Foundations of Prejudice

Arye L. Hillman

Antisemitism and the Victimary Era

Adam Katz

The Antisemitic Imagination

Catherine Chatterley

The Communication Latency of Antisemitic Attitudes: An Experimental Study Heiko Beyer and Ivar Krumpal

The Definition of Antisemitism

Kenneth L. Marcus

Embracing the Nation: Jewish Assimilationist and Anti-Zionist Responses to

Modernity

C.R. Power and Sharon Power

Nationalism and Antisemitism in the Postnational Constellation: Thoughts on Horkheimer, Adorno, and Habermas

Karin Stoegner and Johannes Hoepoltseder

Modern Capitalist Society, Competing Nation States, Antisemitism and Hatred of the Jewish State

Robin Stoller 


\section{THE INTELLECTUAL ENVIRONMENT}

Introduction

Charles Asher Small

Fighting Antisemitism in the Feminist Community

Nora Gold

Campus Antisemitic Speech and the First Amendment

Alexander Tsesis

Marginalization and Its Discontents: American Jews in Multicultural and Identity Studies

Jennifer Roskies

NGOs and the New Antisemitism

Anne Herzberg

The Image of Israel and Israelis in the French, British, and Italian Press During the 1982 Lebanon War

Marianna Scherini

Durban Reviewed: The Transformation of Antisemitism in a Cosmopolitanizing Environment

Elisabeth Kuebler and Matthias Falter

\section{GLOBAL ANTISEMITISM: PAST AND PRESENT}

\section{Introduction}

Charles Asher Small

Antisemitism and Anti-Zionism in the "New" South Africa: Observations and Reflections

Milton Shain

The Politics of Paranoia: How - and Why - the European Radical Right Mobilizes Antisemitism, Xenophobia, and Counter-Cosmopolitanism

Lars Rensmann

Penalizing Holocaust Denial: A View from Europe

Aleksandra Gliszczyńska-Grabias

The Judeo-Masonic Enemy in Francoist Propaganda (1936-1945)

Javier Domínguez Arribas

"Artisans ... for Antichrist": Jews, Radical Catholic Traditionalists, and the Extreme Right

Mark Weitzman

Post-war Antisemitism: Germany's Foreign Policy Toward Egypt

Ulricke Becker 
Great Expectations: Antisemitism and the Politics of Free-Speech Jurisprudence Stephen M. Feldman

A Brief History of Iberian Antisemitism Lina Gorenstein

Antisemitism in Contemporary Poland Marek Kucia

Anti-Jewish "Propaganda" in Brazil under Dutch Occupation Daniela Levy

Antisemitism According to Victor Klemperer Miriam Oelsner

Antisemitic Anti-Zionism Within the German Left-Die Linke Sebastian Voigt

Two Thousand Years of Antisemitism: From the Canonical Laws to the Present Day Anita Waingort Novinsky

\section{ISLAMISM AND THE ARAB WORLD}

Introduction

Charles Asher Small

From Sayyid Qutb to Hamas: The Middle East Conflict and the Islamization of Antisemitism Bassam Tibi

Conspiracy Theories, Antisemitism, and Jews in Turkey Today Rifat N. Bali

Iranian Antisemitism: Continuity and Change Meir Litvak

Muslim Demonization of Jews as "Pigs and Apes": Theological Roots and Contemporary Implications Neil J. Kressel

Nazi Propaganda to the Arab World During World War II and the Emergence of Islamism Jeffrey Herf

Hitler, Hamas, and Jihadist Jew Hatred David Patterson

Muhammad, the Jews, and Khaybar: Fantasy and Emotion in Contemporary Islamic Political and Religious Antisemitism Paul Lawrence Rose

Antisemitism in Iran Wahied Wahdat-Hagh 
The Jihad Flotilla to Gaza: Provocative, Antisemitic, and Not Humanitarian Jonathan Fighel

\section{REFLECTIONS}

Introduction

Charles Asher Small

How Do We Put an End to Antisemitism? No, Really, How Do We?

Ruth R. Wisse

Arab and Islamic Antisemitism

Menahem Milson

The History and Psychological Roots of Antisemitism Among Feminists and Their

Gradual Stalinization and Palestinianization

Phyllis Chesler

The Rabbi and the President: "Don't Give Us the Holocaust at the Expense of Israel"

Walter Reich

Without Ahavath Yisrael: Thoughts on Radical Anti-Zionism at Brandeis

Doron Ben-Atar

Between Opposition and Denial: Radical Responses to Antisemitism in

Contemporary Europe

Robert Fine

The Iranian President, the Canadian Professor, the Literary Journal, and the

Holocaust Denial Conference That Never Was: The Strange Reality of Shiraz Dossa

Deborah E. Lipstadt

Making History: Engaging, Educating, and Empowering Faculty to Address Issues of Antisemitism in the Academy

Edward S. Beck

Struggles over the Boundaries of Legitimate Discourse: Antizionism, Bad-Faith

Allegations and The Livingstone Formulation

David Hirsh

The Language of the New Antisemitism

Michael C. Kotzin

The EU, the Middle East, and Antisemitism

Leslie S. Lebl

The Unique Nature of Palestinian Antisemitism: A Foundation of Palestinian

National Identity

Itamar Marcus

Some Philosophical Reflections on Antisemitism Today

Alan S. Rosenbaum 
Modern Antisemitism and National Identity Ilka Schroeder

Sisterhood Was Powerful and Global: Where Did It Go?

Thyme S. Siegel

Progress in Combating Antisemitism at the International Level Michael Whine

The Effect of the Resurgence of Antisemitism on Holocaust Survivors Barbara Wind 
